GABRIELA ANDRÉ JORGE

AVALIAÇÃO DA VIABILIDADE DE MAPEAMENTO DAS TAREFAS DO CONSUMIDOR EM PROCESSOS DE SERVIÇOS

São Paulo

2013 


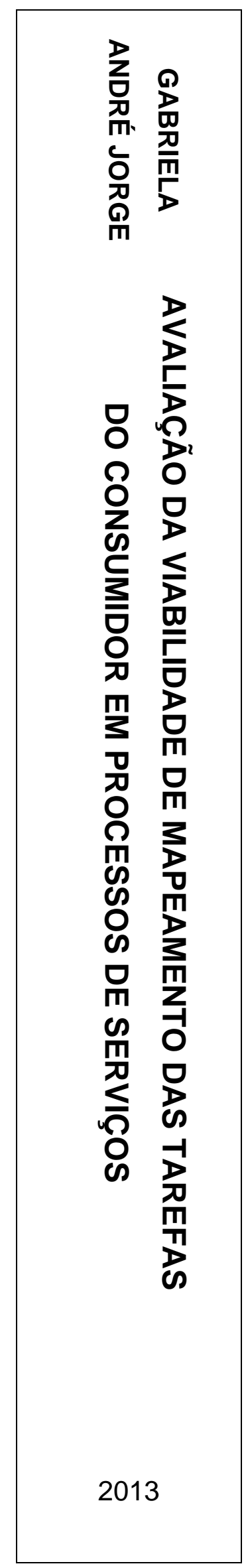




\title{
AVALIAÇÃO DA VIABILIDADE DE MAPEAMENTO DAS TAREFAS DO CONSUMIDOR EM PROCESSOS DE SERVIÇOS
}

\author{
Dissertação apresentada a Escola \\ Politécnica da Universidade de São \\ Paulo para obtenção do título de Mestre \\ em Ciências \\ Área de Concentração: \\ Engenharia de Produção \\ Orientador: Prof. Livre-Docente \\ Dario Ikuo Miyake
}

São Paulo

2013 
Autorizo a reprodução e divulgação total ou parcial deste trabalho, por qualquer meio convencional ou eletrônico, para fins de estudo e pesquisa, desde que citada a fonte.

Este exemplar foi revisado e alterado em relação à versão original, sob responsabilidade única do autor e com a anuência de seu orientador.

São Paulo, 05 de junho de 2013

Assinatura da autora

Assinatura do orientador

FICHA CATALOGRÁFICA

Jorge, Gabriela André

Avaliação da viabilidade de mapeamento das tarefas do comsumidor em processos de serviços / G.A. Jorge. - versão corr. -- São Paulo, 2013.

$191 \mathrm{p}$.

Dissertação (Mestrado) - Escola Politécnica da Universidade de São Paulo. Departamento de Engenharia de Produção.

1. Serviços (Viabilidade; Avaliação) 2. Mapeamento de processos em serviço I. Universidade de São Paulo. Escola Politécnica. Departamento de Engenharia de Produção II. t. 


\title{
AVALIAÇÃO DA VIABILIDADE DE MAPEAMENTO DAS TAREFAS DO CONSUMIDOR EM PROCESSOS DE SERVIÇOS
}

\author{
Dissertação apresentada a Escola \\ Politécnica da Universidade de São \\ Paulo para obtenção do título de Mestre \\ em Ciências
}

Aprovado em:

\section{Banca Examinadora}

Prof. Dr. Dario Ikuo Miyake

Instituição: Escola Politécnica - Universidade de São Paulo Julgamento:

Assinatura:

Prof. Dra. Márcia Terra da Silva

Instituição: Escola Politécnica - Universidade de São Paulo Julgamento:

Assinatura:

Prof. Dr. Noel Torres Junior

Instituição: Faculdade de Ciências Econômicas - Universidade Federal de Minas Gerais

Julgamento:

Assinatura: 


\section{DEDICATÓRIA}

Dedico este trabalho aos meus pais pelo exemplo de pessoas boas que são e ao meu companheiro, amigo e amor Julio que me inspira e apoia em cada um dos meus desafios. 


\section{AGRADECIMENTOS}

A Deus, acima de tudo, que inspira e conduz a minha vida.

Ao professor Dario Ikuo Miyake que por meio da sua orientação exemplar possibilitou que esta dissertação de mestrado se concretizasse. Aos professores Márcia Terra da Silva e Paulino Graciano Francischini cujas contribuições na banca de qualificação serviram de insumo para enriquecer o estudo.

Aos meus pais e às minhas irmãs por estarem sempre presentes dando o apoio necessário em todas as situações.

Agradeço, especialmente, ao meu namorado Julio pelo incentivo, companhia, imenso suporte e contribuição no desenvolvimento e nas revisões do trabalho. 


\section{RESUMO}

Esta dissertação aborda o problema da falta conhecimento a respeito do processo de mapeamento e avaliação das tarefas executadas pelos consumidores em processos de serviços reais. De fato, a literatura acerca da construção de mapas que permitam visualizar as tarefas desempenhadas pelos consumidores nos processos de serviço ainda se mostra escassa o que motiva o desenvolvimento de pesquisas que venham a contribuir para a sistematização e difusão de tal prática. Neste contexto, este trabalho objetiva contribuir com o gerenciamento e controle das operações de serviço verificando como a participação do consumidor nos processos de serviço pode ser mapeada e medida. Desta forma são considerados os seguintes objetivos específicos: a) Verificar como a literatura propõe a construção de mapas para visualizar as tarefas executadas pelos consumidores em processos de serviço; b) Aplicar o Mapa de Consumo em casos reais de serviço detalhando como a construção deste mapa pode ser conduzida, identificando e medindo as tarefas desempenhadas pelos consumidores; c) Identificar as principais dificuldades encontradas na construção do Mapa de Consumo e medição das tarefas dos consumidores. As principais ferramentas identificadas na revisão da literatura para a forma de mapeamento focada foram o SIPOC, Blueprint, Mapa de Consumo, Carta de Atividades e SERVPRO. Realizou-se então uma análise comparativa das mesmas, procurando-se destacar aspectos singulares da forma como propõem que a participação do consumidor no processo de serviço seja visualizada. Para se coletar dados empíricos sobre a aplicação de uma ferramenta de mapeamento com o propósito de representar e analisar a participação do consumidor, a pesquisa explora o potencial de aplicação da ferramenta Mapa de Consumo, proposta por Womack e Jones (2006), no estudo das tarefas e interações que compõem processos de serviço em que o consumidor atua como coprodutor, exercendo papel fundamental para concretização do serviço. Assim, o escopo desta pesquisa foi delimitado à consideração de processos de serviço do tipo "faça você mesmo" com interação remota e com interação presencial, entre cliente e provedor, em casos nos quais a variabilidade do processo é baixa. O serviço do tipo "faça você mesmo" com interação remota selecionado como objeto de estudo foi um processo de compra coletiva pela internet, e para seu mapeamento foram adotados os métodos de coleta 
de dados por estudo de caso, utilizando a empresa provedora do serviço como fonte de dados, e experimento, recorrendo aos seus consumidores como fonte de dados. Para o serviço do tipo "faça você mesmo" com interação presencial, selecionou-se o processo de estacionar o carro em um shopping center, e para seu mapeamento foi adotado o método de coleta de dados por meio de uma enquete realizada in loco com seus consumidores. Ao final da pesquisa, conclui-se que a construção e aplicação do Mapa de Consumo para os processos de serviço do tipo "faça você mesmo", tanto na modalidade com interação remota como na modalidade com interação presencial são viáveis e que as principais dificuldades acerca da construção dos mapas referem-se ao tempo requerido para coleta dos dados e a adesão de participantes à pesquisa.. Além disso, são elencadas propostas para o desenvolvimento de pesquisas futuras relacionadas ao tema abordado nesta dissertação.

Palavras-chaves: Processos de serviço. SIPOC. Blueprint. Mapa de Consumo. Carta de Atividades. SERVPRO. 
ABSTRACT

This dissertation examines the problem of lack of knowledge about the process of mapping and evaluating the tasks performed by consumers in real service processes. Indeed, the literature about the construction of maps that enable the visualization of tasks undertaken by consumers in service processes are still scarce, what motivates the development of research works that might contribute to the systematization and dissemination of such practice. In this context, this work aims at contributing to the management and control of service operations, by examining how the consumer participation in service processes can be mapped and measured. Thus, the following objectives are considered: a) Verify how the literature proposes the construction of maps to visualize the tasks performed by consumers in service processes; b) Apply the Consumption Map in cases of real service detailing how the construction of this map can be conducted, by identifying and measuring tasks undertaken by consumers; c) Identify the main difficulties encountered in the construction of Consumption Map and in the measurement of consumer tasks. The main tools identified in the literature review to address this kind of mapping were SIPOC, Blueprint, Consumption Map, Activity Chart and SERVPRO. A comparative analysis of these tools was developed seeking to highlight unique aspects of the way how they propose that consumer participation in the service process be displayed. To collect empirical data on the application of a mapping tool with the purpose of representing and analyzing the participation of consumer, the research explores the potential application of the Consumption Map tool, proposed by Womack and Jones (2006), in the study of tasks and interactions that compose service processes in which the consumer acts as co-producer, playing a fundamental role for the realization of the service. Therefore, the purpose of this research was limited to the analysis of service processes of "do it yourself" type with remote interaction and with face-to-face interaction between customer and provider, in cases in which process variability is low. The "do it yourself" type of service with remote interaction selected as the object of the study was a process of shared shopping by the internet, and for its mapping the data collection method adopted were the case study, using the service provider company as data source, and experiment, using its consumers as data source. For the "do it yourself" type of service with face-to-face interaction, it 
was selected the car parking process in a shopping center, and the data collection method adopted for its mapping was a survey conducted in situ with its consumers. At the end of the research, it is concluded that the construction and application of Consumption Map for service processes of "do it yourself" type, either in remote interaction mode or in face-to-face interaction mode are feasible and that the main difficulties in the construction of the maps refer to the time required for data collection and the adherence of participants to the research. Also, proposals for the development of future research related to the topic covered in this dissertation are listed.

Keywords: Service Processes. SIPOC. Blueprint. Consumption Map. Activities Chart. SERVPRO. 


\section{LISTA DE ILUSTRAÇÕES}

Figura 1 - Elementos chave de um conceito de serviço ........................................24

Figura 2 - Modelo da Lógica do Serviço (Service Logic Model)..............................26

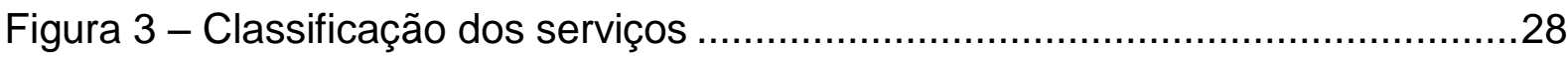

Figura 4 - Matriz das áreas de decisão-chave …………………......................44

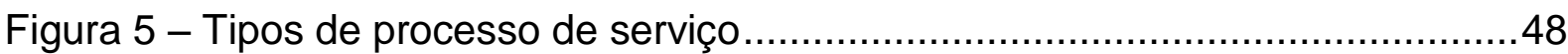

Figura 6 - Delimitação do escopo da pesquisa ...................................................52

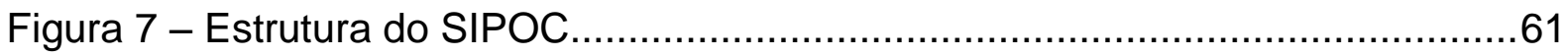

Figura 8 - Descrição do processo para emitir uma nova apólice de seguro ..............62

Figura 9 - Blueprint de uma floricultura delivery ...............................................63

Figura 10 - Blueprint para um hotel de luxo.....................................................64

Figura 11 - Blueprint do processo de reparo de um produto na garantia ..................67

Figura 12 - Mapa de Consumo de um processo de reparo de automóvel................69

Figura 13 - Mapa do Provedor de um processo de reparo de automóvel..................70

Figura 14 - Escala visual utilizada para retratar a satisfação ou incômodo das pessoas envolvidas no processo em relação às tarefas executadas .....72

Figura 15 - Fluxo de valor completo combinando Mapa de Consumo e Mapa de Provisão .72

Figura 16 - Exemplo de Carta de Atividades .75

Figura 17 - Diagrama SERVPRO para o processo do consumidor de um restaurante self-service .77

Figura 18 - Ícones para indicar a interação entre cliente e sistema. .77

Figura 19 - Documento de elaboração SERVPRO para o processo de pagar a conta de um restaurante .78 
Figura 20 - Utilização da cadeia de valor do consumidor para visualização das relações entre as partes envolvidas no ciclo de vida do produto .85

Figura 21 - Rede de Relacionamentos decorrentes da quebra de um freezer 86

Figura 22 - Delimitação do escopo da pesquisa 91

Figura 23 - Fluxo do processo de compra coletiva na visão do consumidor 110

Figura 24 - Mapa detalhado do processo das tarefas executadas pelo consumidor no processo de compra coletiva. 110

Figura 25 - Painel de gestão Google Analytics da empresa Cupom 113

Figura 26 - Mapa de Consumo do processo de compra coletiva através dos dados fornecidos pela empresa provedora do serviço capturado via Google Analytics 118

Figura 27 - Mapa de Consumo construído através dos dados do experimento 127

Figura 28 - Mapa de Consumo construído com base em dados levantados por meio do estudo de caso em uma empresa e do experimento com os consumidores 132

Figura 29 - Representação do grau de satisfação do consumidor em relação ao processo de estacionar o carro 135

Figura 30 - Mapa do processo das tarefas executadas pelo consumidor no processo de estacionar o carro. 137

Figura 31 - Mapa detalhado das tarefas executadas pelo consumidor no processo de estacionar o carro em shopping center 137

Figura 32 - Um extrato dos dados obtidos por meio da enquete 140

Figura 33 - Mapa de Consumo do processo de estacionar o carro no sistema "ticket na catraca" 142 
Figura 34 - Mapa de Consumo do processo de estacionar o carro no sistema "sem

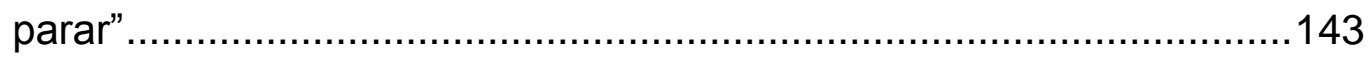




\section{LISTA DE QUADROS}

Quadro 1 - Relação das seções do trabalho atreladas às questões de pesquisa ....36

Quadro 2 - Resultados que se procurou obter com o estudo de caso....................98

Quadro 3 - Variáveis consideradas no experimento .....................................99

Quadro 4 - Resultados que se pretende obter com o experimento .....................100

Quadro 5 - Variáveis consideradas na enquete...........................................103

Quadro 6 - Resultados que se pretende obter com a enquete ...........................104 


\section{LISTA DE GRÁFICOS}

Gráfico 1 - Distribuição dos artigos levantados por base de publicação

Gráfico 2 - Distribuição dos artigos levantados por ano de publicação .57

Gráfico 3 - Tempo médio do visitante no site por dia, por semana e por mês.

Gráfico 4 - Gráfico linear dos tempos médios diários de permanência no site dos visitantes que não finalizaram a compra

Gráfico 5 - Gráfico linear dos tempos médios diários de permanência no site dos visitantes que finalizaram a compra

Gráfico 6 - Histograma dos tempos médios diários de permanência no site dos visitantes que não finalizaram a compra 116

Gráfico 7 - Histograma dos tempos médios diários de permanência no site dos visitantes que finalizaram a compra

Gráfico 8 - Taxa de rejeição do site (parcela dos consumidores que visitaram o site e não finalizaram a compra).

Gráfico 9 - Histograma do tempo gasto pelos consumidores para executar a compra 125

Gráfico 10 - Histograma do tempo de espera para recepção do cupom de desconto 125

Gráfico 11 - Histograma do tempo de impressão do cupom 126

Gráfico 12 - Boxplot do tempo gasto pelos consumidores para executar a compra 129

Gráfico 13 - Boxplot do tempo gasto pelos consumidores para executar a compra estratificados em subgrupos formados por aqueles que fizeram a primeira compra pelo site ou não 130 
Gráfico 14 - Boxplot do tempo gasto pelos consumidores para executar a compra, agrupados pelo subgrupo forma de pagamento 131

Gráfico 15 - Histograma do tempo gasto para estacionar o carro utilizando o ticket do estacionamento 140

Gráfico 16 - Histograma do tempo gasto para estacionar o carro utilizando o sistema "sem parar" 141

Gráfico 17 - Adesão dos consumidores a enquete 145

Gráfico 18 - Tempo gasto pelos consumidores que utilizaram o sistema "ticket na catraca" para estacionar em vaga comum e em vaga especial 146

Gráfico 19 - Grau de satisfação dos consumidores que utilizaram o sistema "ticket na catraca" na execução do processo de estacionar o carro.

Gráfico 20 - Grau de satisfação dos consumidores que utilizaram o sistema "sem parar" na execução do processo de estacionar o carro.

Gráfico 21 - Relação da satisfação do consumidor com o tempo gasto para estacionar o carro no sistema "ticket na catraca" 148

Gráfico 22 - Relação da satisfação do consumidor com o tempo gasto para estacionar o carro no sistema "sem parar". 148

Gráfico 23 - Tempo gasto pelos consumidores para estacionar no domingo e na quinta-feira 150 


\section{LISTA DE TABELAS}

Tabela 1 - Comparação entre as categorias de serviços .46

Tabela 2 - Características dos serviços "Faça você mesmo" e "Fábrica de serviço" .50

Tabela 3 - Diferencial das ferramentas de mapeamento em relação à forma de visualização do papel do consumidor em um processo de serviço .......79

Tabela 4 - Comparação entre as ferramentas de mapeamento do consumidor.....81

Tabela 5 - Benefícios e desafios dos serviços eletrônicos ……………………....96

Tabela 6 - Métodos de pesquisa empregados …………………………......106

Tabela 7 - Parâmetros das distribuições do tempo médio diário de permanência dos consumidores no site.

Tabela 8 - Dados coletados através do experimento com consumidores 122

Tabela 9 - Tempo de permanência dos consumidores no site ${ }^{*}$ 126

Tabela 10 - Tempo gasto para estacionar o carro em um shopping center 141

Tabela 11- Dificuldades e aspectos positivos identificados na aplicação dos métodos de pesquisa considerados para mapeamento do processo do tipo "faça você mesmo" com interação remota 156

Tabela 12 - Dificuldades e aspectos positivos identificados na aplicação do método de pesquisa da enquete para mapeamento do processo do tipo "faça você mesmo" com interação presencial 159

Tabela 13 - Fontes de dados adotadas para o processo do tipo "faça você mesmo" com interação remota e dados coletados 164

Tabela 14- Fonte de dados adotada para o processo do tipo "faça você mesmo" com interação presencial e dados coletados 166 
Tabela 15 - Viabilidade de aplicação da ferramenta Mapa de Consumo 168

Tabela 16 - Tempo dedicado pela pesquisadora para mapeamento da participação

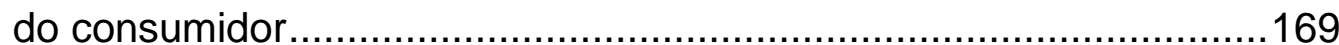


1. INTRODUÇÃO

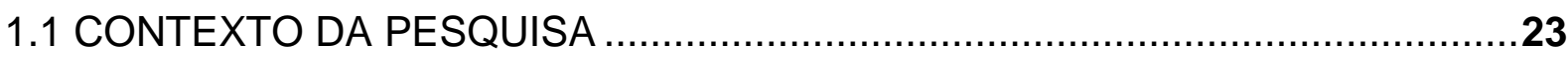

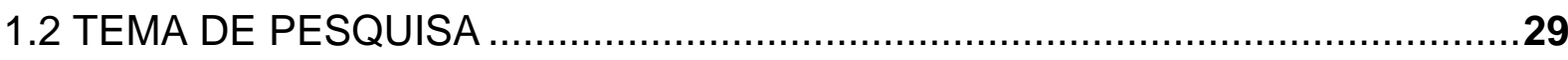

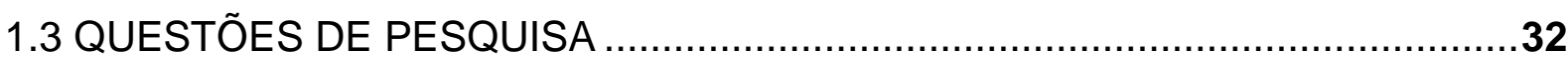

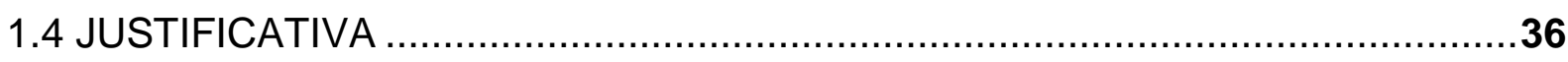

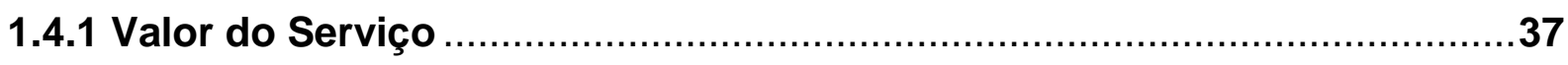

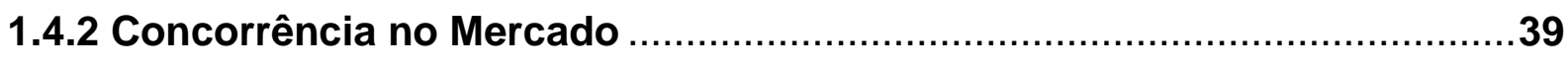

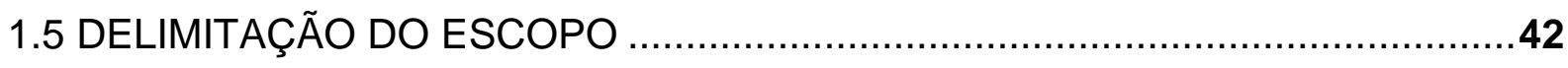

1.5 OBJETIVO.

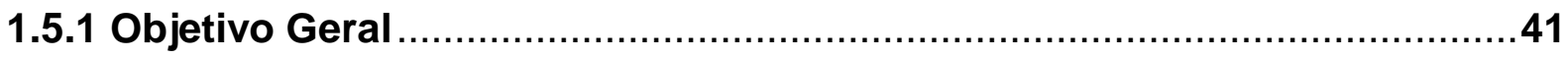

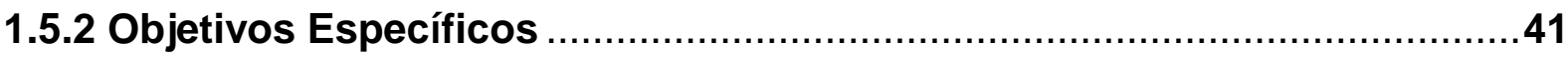

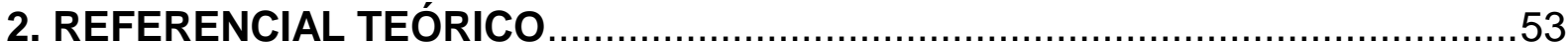

2.1 FERRAMENTAS DE MAPEAMENTO DO CONSUMIDOR …............................59

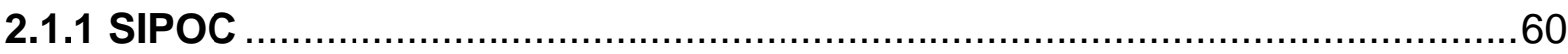

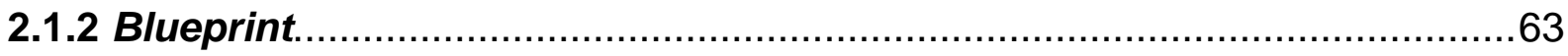

2.1.3 Mapa de Consumo

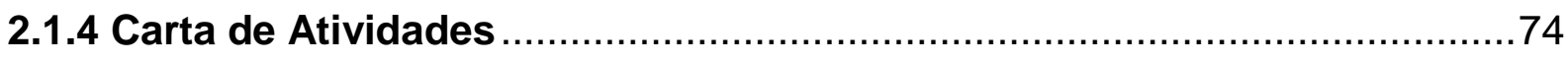

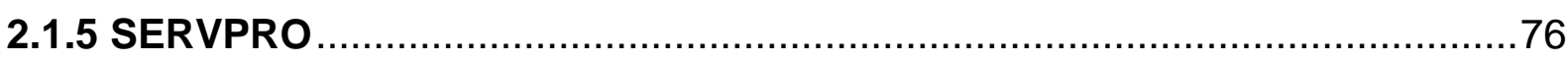

2.1.6 Comparação entre as Ferramentas de Mapeamento do Consumidor .......78

2.2 DEMAIS FERRAMENTAS DE MAPEAMENTO …........................................83

2.2.1 Análise da Cadeia de Valor do Consumidor (customer value chain) ........84

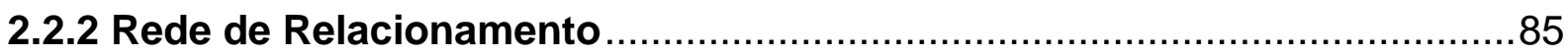




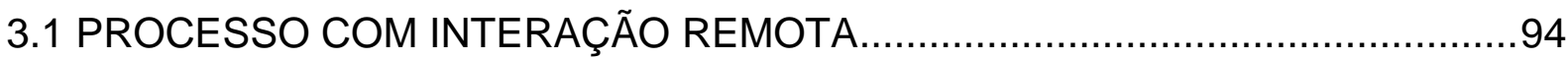

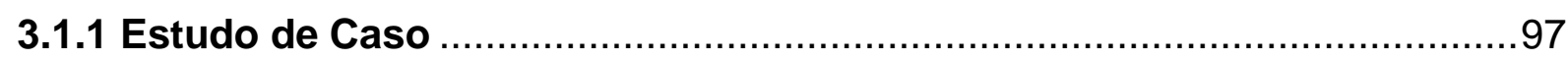

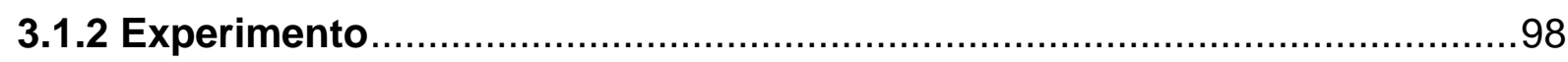

3.2 PROCESSO COM INTERAÇÃO PRESENCIAL ............................................101

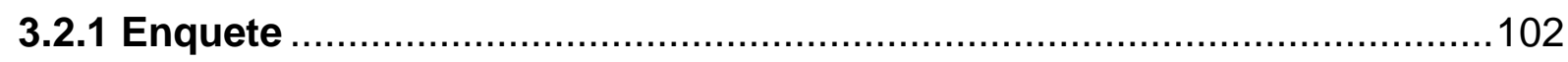

4 DESCRIÇÃO E ANÁLISE DO PROCESSO COM INTERAÇÃO REMOTA .........107

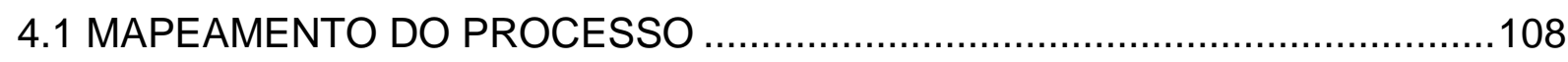

4.2 MEDIÇÃO DAS TAREFAS EXECUTADAS PELO CONSUMIDOR ..................111

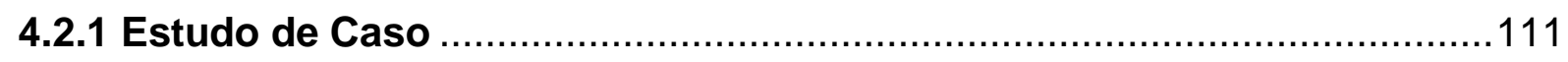

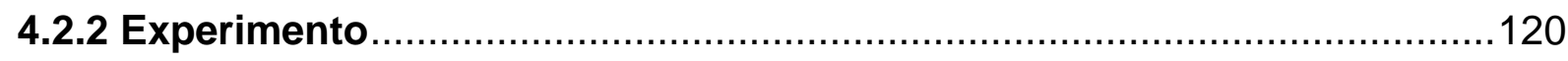

4.2.2.1 Análise dos dados para construção do Mapa de Consumo ........................124

4.2.2.2 Análise dos dados complementares.....................................................128

4.2.3 Estudo de Caso e Experimento Consolidados .....................................132

5 DESCRIÇÃO E ANÁLISE DO PROCESSO COM INTERAÇÃO PRESENCIAL.134

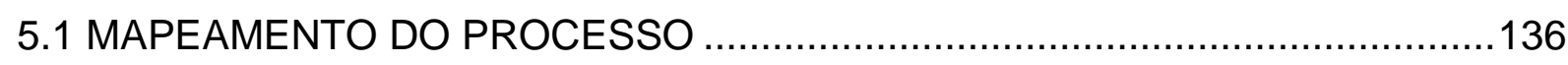

5.2 MEDIÇÃO DAS TAREFAS EXECUTADAS PELO CONSUMIDOR ...................138

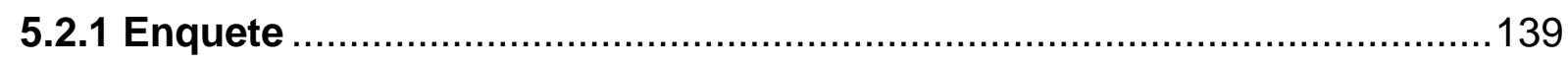

5.2.1.1 Análise dos dados para construção do Mapa de Consumo ........................139

5.2.1.2 Análise dos dados complementares .....................................................144

6 DIFICULDADES E PONTOS POSITIVOS IDENTIFICADOS NA CONSTRUÇÃO

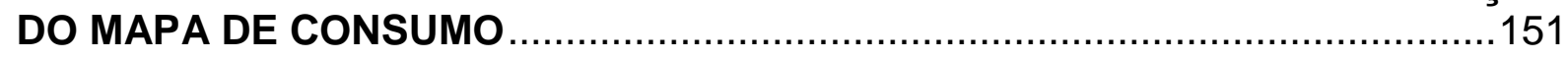

6.1 "FAÇA VOCÊ MESMO” COM INTERAÇÃO REMOTA ………........................151

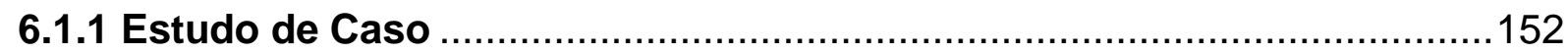

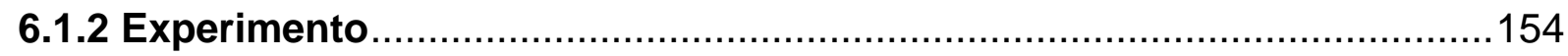


7 CONCLUSÕES

7.1 CONCLUSÕES DECORRENTES DAS QUESTÕES DE PESQUISA

7.2 LIMITAÇÕES DO TRABALHO

APÊNDICE A - Questionário utilizado como guia para realização das entrevistas com as empresas de compra coletiva

APÊNDICE B - Entrevista realizada para prospectar empresa para o estudo de caso da categoria de serviço 183

APÊNDICE C - Tabela de medição e instruções enviadas para potenciais consumidores para realização do experimento 185

APÊNDICE D - Versão inicial da planilha eletrônica de medição utilizada na etapa piloto de planejamento do experimento 188

APÊNDICE E - Planilha de medição utilizada como base para realização da enquete visando a construção do Mapa de Consumo para um processo .......189

APÊNDICE F - Dados coletados na enquete visando a construção do Mapa de Consumo para um processo 


\section{INTRODUÇÃO}

As práticas de gerenciamento e controle da produção de serviços avançaram largamente nos últimos anos na esfera acadêmica e empresarial e mostram que algumas abordagens originalmente adotadas na manufatura podem ser também aplicadas no setor de serviços, ainda que adaptadas às particularidades existentes na avaliação, controle e processamento destes. Apesar dos avanços neste campo, encontram-se lacunas no conhecimento fazendo-se necessária maior exploração de conceitos e métodos para o gerenciamento e controle das operações de serviço.

O setor de serviço apresenta uma evolução significativa na economia: segundo o IBGE, sua representatividade no PIB brasileiro em 2010 foi de 58\% (IBGE, 2011). Outro fator que demonstra a importância deste setor na economia atual é a tendência de agregação de serviço aos produtos que se iniciou na década de 90 , quando as empresas de manufatura passaram a ter o serviço como diferencial competitivo. Este processo de agregação do serviço à manufatura é definido por Vandermerwe e Rada (1988) como servitização. "A habilidade das empresas em prover maior valor para os consumidores é considerada uma das estratégias competitivas de maior sucesso nos anos 90" (RAVALD; GRÖNROOS, 1996, p. 19).

A representatividade do setor de serviços na economia e a servitização das empresas de manufatura demonstram a relevância desta área na atualidade e a necessidade de expandir as pesquisas sobre o gerenciamento e controle de operações neste setor.

Diversas características diferenciam processos de serviço dos processos de manufatura. Lovelock e Gummesson (2004) destacam a característica de não transferência de propriedade existente nos processos de serviço para diferenciá-los dos da manufatura na qual o consumidor torna-se dono de um bem manufaturado pelo produtor. Fitzsimmons e Fitzsimmons (2004) apontam que os processos de serviços apresentam características particulares que os diferenciam dos processos de manufatura como simultaneidade, perecibilidade, heterogeneidade e intangibilidade. Essas características estão atreladas a um fator de diferenciação 
dos processos de serviço em relação à manufatura: a participação do consumidor no processo de serviço.

Diferentemente do que ocorre na manufatura, no serviço o consumidor é um agente ativo do processo de produção, sendo que sua participação pode variar em intensidade e relevância, mas influencia a prestação do serviço e a percepção de valor em relação ao resultado final.

Wild (1977) define serviços como mudança de estado do cliente ou de um bem que pertença ao cliente. O serviço é qualquer atividade prestada pela empresa aos seus clientes que não constitui um produto físico, um bem, e geralmente caracteriza-se por ser consumido ao mesmo tempo em que é produzido (simultaneidade) e por apresentar resultados intangíveis, além de apresentar características de perecibilidade e heterogeneidade.

O atributo de intangibilidade está atrelado ao aspecto subjetivo dos serviços, diz respeito à percepção do consumidor em relação ao resultado final do processo de serviço. Enquanto na manufatura o resultado refere-se a um bem que pode ser visto, tocado e segurado (SILVA; LANCMAN; ALONSO, 2009) de forma concreta, o serviço apresenta características subjetivas atreladas à experiência do consumidor, sendo percebido, sentido e visto. Esta característica traduz a compreensão do cliente em relação ao resultado adquirido no processo de serviço, apesar de poder existir diversos componentes tangíveis no processo de prestação do serviço, o resultado em si é intangível e de difícil padronização, avaliação ou comparação, pois depende da percepção do cliente em relação ao resultado do serviço (SILVA, 2010).

A característica de simultaneidade significa que a constituição e consumo do serviço ocorrem paralelamente e em conjunto. O processo de prestação de um serviço ao mesmo tempo em que "fabrica" o serviço "entrega" o resultado final do processo. Este momento de constituição e prestação do serviço é denominado "encontro de serviço". A simultaneidade também implica que o serviço não pode ser estocado e que a variabilidade da demanda atingirá diretamente o processo de serviço. A falta da demanda pode ocasionar a subutilização dos recursos disponíveis e, em contrapartida, o excesso da demanda resulta em fila de clientes (ou de seus bens). 
Os recursos utilizados para prestação do serviço podem ser estocados, porém, o serviço por sua concepção não, pois o serviço somente se concretizará quando o cliente estiver usufruindo o que the foi ofertado. Isto também significa que se a capacidade de prestação do serviço não for utilizada na sua totalidade durante um determinado período de tempo, não poderá produzir saídas para serem consumidas posteriormente. Este aspecto evidencia a perecibilidade do serviço. Desta forma, ocorrem casos em que a demanda do serviço precisa ser ajustada à capacidade de processamento do provedor através, por exemplo, de promoções. (BOWEN; FORD, 2002)

A heterogeneidade do serviço está atrelada ao grau de variação no resultado do processo. Isto ocorre, pois o consumidor interfere no processo de serviço sendo (ou possuindo) o insumo a ser transformado. Além da interferência do consumidor como insumo do processo, muitas vezes ele atua como co-produtor do serviço, desempenhando atividades que anteriormente eram executadas pela empresa. "Quanto maior a participação do cliente e sua liberdade de escolha, maior será a heterogeneidade do processo" (SILVA, 2010, p. 32).

Esta pesquisa visa, pois, estudar os processos de serviço em que o consumidor atua como co-produtor do processo.

\subsection{CONTEXTO DA PESQUISA}

Por apresentarem características específicas os processos de serviço trazem desafios para o gerenciamento das operações, exigindo uma estratégia de atuação diferenciada em relação às aplicações de gerenciamento da manufatura. Na Figura 1 se observam os elementos chave para conceituação de serviço propostos por Johnston e Clark (2002) e Johnston e Jones (2004). 


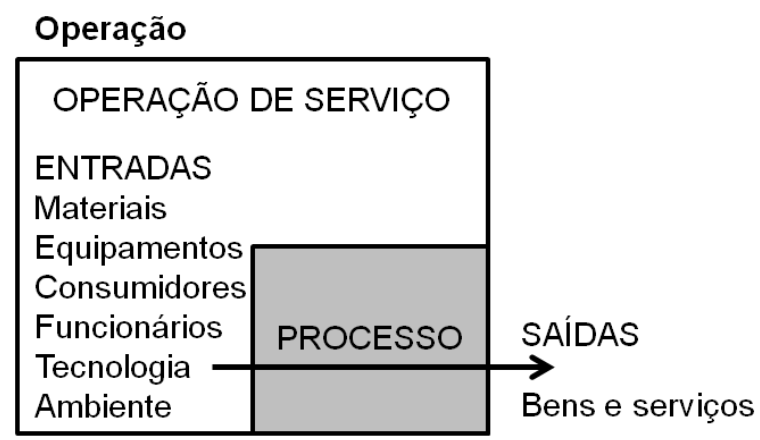

Figura 1 - Elementos chave de um conceito de serviço

Fonte: Adaptada de Johnston e Jones (2004, p. 203); Johnston e Clark (2002, p. 60)

Para conceber um serviço são necessárias entradas e a execução de diversas atividades inter-relacionadas, em uma sequência apropriada que resultem no produto do serviço (JOHNSTON; CLARK, 2002). O elemento de destaque no processo de prestação do serviço, que o difere da manufatura, é a participação do consumidor como um agente participativo do processo de serviço, podendo exercer diversos papéis neste cenário, como: comprador, recurso, co-produtor, usuário, produto, concorrente ou parceiro (TORRES JUNIOR, 2007). O papel do consumidor de co-produtor nos processos de serviço será abordado neste estudo através da expressão "processo do consumidor" derivado da expressão "processo de consumo" utilizada pelos autores Womack e Jones (2006) para abordar as atividades executadas pelos consumidores durantes o processo de serviço.

Enquanto na manufatura o cliente permanece como espectador do processo, limitando-se a atuar somente na compra do bem, no processo de serviço ele influencia o processo de serviço interagindo com a organização provedora e, muitas vezes, exercendo papel de co-produtor, ou seja, executa tarefas que poderiam ser feitas pela empresa prestadora do serviço, mas que são atribuídas aos consumidores que se tornam "funcionários parciais" da empresa. O grau de participação do consumidor no processo pode ser baixa, média ou alta de acordo com os papéis e responsabilidades que lhe são atribuídas (ZEITHAML; BITNER, 2003).

A alta participação do consumidor significa que ele atua como co-criador do serviço, criativamente auxiliando na construção do processo de serviço e no resultado, 
personalizando o serviço às suas necessidades específicas. Nesta classificação encaixam-se os serviços nos quais o resultado é a transformação do próprio consumidor. Isto ocorre, por exemplo, no caso de projetos de reforma, uma viagem, ou ainda, em serviços de resultados ulteriores (TORRES JUNIOR, 2007).

Um nível moderado de participação do consumidor está atrelado a serviços onde o consumidor atua como executor, co-produtor, do processo ou de parte do processo. O consumidor é responsável por tarefas que a empresa poderia executar, mas que, para aumento da conveniência do consumidor ou para redução do custo operacional da empresa, foram repassadas para serem operacionalizadas pelo consumidor.

Este tipo de processo de serviço pode ser verificado em casos como, por exemplo, caixa eletrônico, preenchimento de fichas cadastrais, compra pela internet, atualização dos softwares do computador. O nível moderado ainda abrange casos onde o consumidor fornece informações, materiais - recursos próprios - para atingir o resultado do serviço, ou ainda quando o resultado do serviço é a transformação de um bem do cliente como na manutenção de um carro ou eletrodoméstico.

O consumidor como co-produtor participa como um empregado parcial da empresa, com responsabilidades e roteiros específicos definidos pelas normas sociais ou pelo processo previsto pela organização provedora do serviço (FITZSIMMONS; FITZSIMMONS, 2005).

Quando novas atividades são atribuídas ao consumidor, ou quando ocorrem alterações nos padrões de atividades anteriormente já conhecidas, podem surgir dificuldades na execução e aceitação do processo.

Por fim, atribui-se uma baixa participação do consumidor quando o mesmo solicita e/ou observa a execução do serviço sem grande influência sobre a execução do mesmo como no caso de restaurantes a la carte. Neste tipo de serviço o cliente atua fortemente como demandante do serviço, mas não atua como co-produtor executando as atividades para atingir o resultado.

Kingman-Brundage, George e Bowen (1995) explicam a lógica do serviço através de três componentes chaves: consumidor, funcionário e técnica. Enquanto as particularidades dos consumidores introduzem a imprevisibilidade no processo (" $E u$ 
quero que seja feito do meu jeito"), as diferenças entre os funcionários influenciam na variabilidade do processo e, por consequência, no desempenho do serviço ("Eu farei do meu jeito").

Na Figura 2 verifica-se o modelo da lógica de serviço (service logic model) através do qual se observa a sinergia que precisa ser assegurada nos processos de serviço.

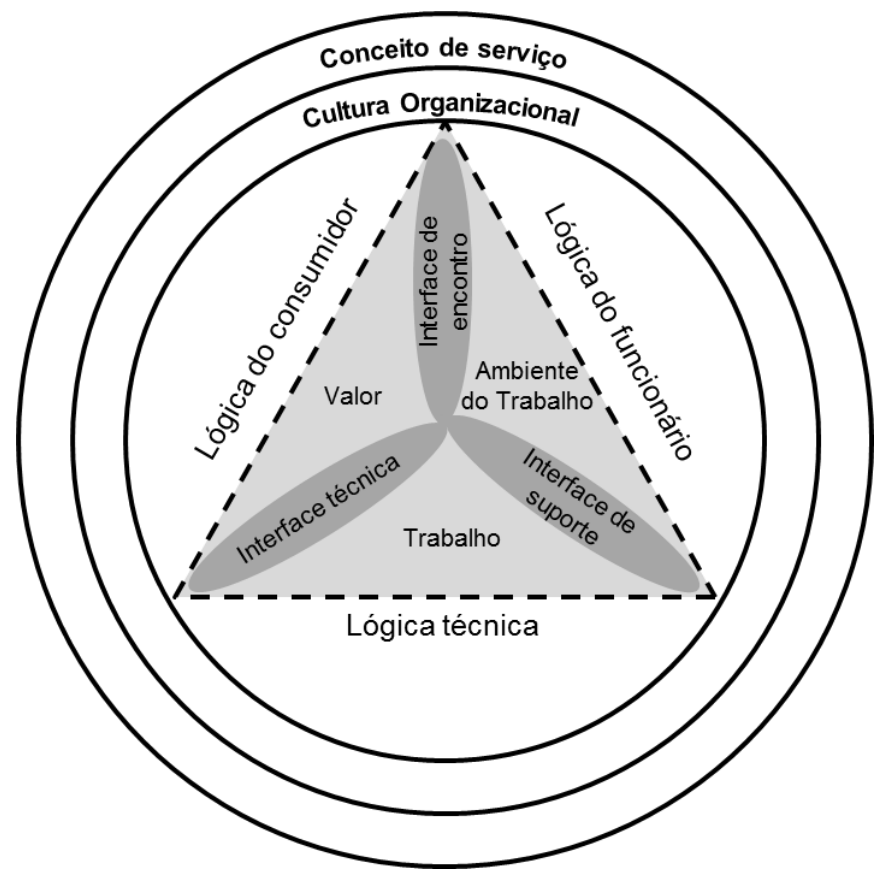

Figura 2 - Modelo da Lógica do Serviço (Service Logic Model)

Fonte: Adaptada de Kingman-Brundage; George e Bowen (1995, p. 24)

A lógica do consumidor destaca que este é aliado no processo de serviço e frequentemente envolvido na co-produção.

O processo de serviço ocorre no encontro entre empresa (funcionários e/ou sistemas) e consumidor, quando estes trocam informações, experiências e expectativas. Este momento de contato entre empresa e consumidor ocorre na linha de frente (Front Office) e tem grande influência na percepção de valor do consumidor, sendo denominado "momento da verdade", "hora da verdade", "encontro de serviço" ou "experimentação do serviço" (VOSS; ZOMERDIJK, 2007). 
Segundo Albrecht (1992), as "horas da verdade" que são vivenciadas pelo consumidor à medida que experimenta o serviço compõem uma cadeia contínua denominada ciclo de serviço. Este autor destaca que cada episódio em que o consumidor entra em contato com a organização provedora do serviço resulta em uma avaliação do serviço pelo consumidor. O "encontro de serviço" pode ocorrer de diferentes formas e com diferentes graus de envolvimento do consumidor, mas sempre se denomina linha de frente 0 ambiente onde esta interação entre consumidor e empresa acontece. Por outro lado, as atividades da empresa que acontecem sem qualquer interação com o consumidor são realizadas no ambiente da retaguarda (Back Office).

A forma do encontro está atrelada à maneira como ocorre a interação entre empresa e consumidor, que pode ser via sistema, pela internet, pelo telefone ou presencialmente. $O$ grau de envolvimento do consumidor relaciona-se à responsabilidade que lhe é atribuída sobre as tarefas executadas para se alcançar o resultado final. A customização do processo, ademais, representa a flexibilidade da empresa em alterar seus processos para atender as necessidades específicas dos consumidores, contudo quanto maior o grau de customização, maior também a variabilidade do processo de prestação do serviço.

O grau de customização do processo é um dos fatores utilizados para caracterização do serviço. Silvestro et al. (1992) classificam os serviços em três categorias: profissional, loja de serviço ou massa onde relaciona o volume de clientes processados com outros seis atributos: (i) Foco na pessoa ou no equipamento; (ii) Tempo de contato entre empresa e cliente; (iii) Grau de customização do serviço; (iv) Grau de discrição do processo; (v) Foco na linha de frente ou na retaguarda; (vi) Foco no processo ou no produto.

A relação entre estes atributos e o volume de clientes processados define o tipo de serviço conforme se pode observar na Figura 3. 


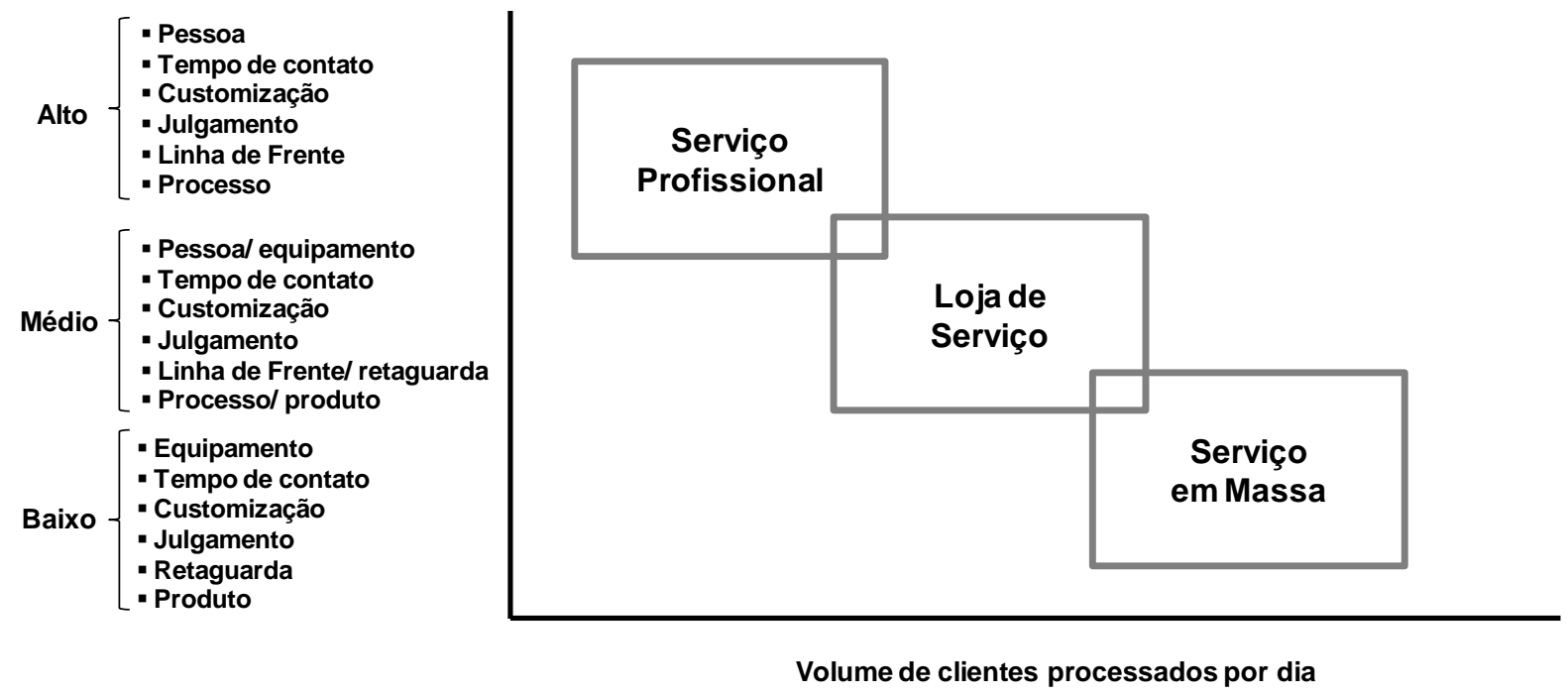

Figura 3 - Classificação dos serviços

Fonte: Adaptada de Silvestro et al. (1992, p. 73)

As três categorias de serviço definidas por Silvestro et al. (1992) são caracterizadas a seguir:

a) Serviço profissional: executado principalmente pelas pessoas, com um alto grau de contato entre consumidor e empresa, alta customização do processo e alto julgamento durante o momento de encontro do serviço. As atividades acontecem primordialmente na linha de frente e foca no processo de serviço.

b) Loja de serviço: trata-se de uma categoria mais ampla dos tipos de serviços, onde o processo varia, podendo ocorrer customizações, pode estar focado no processo ou no produto e com envolvimento maior da linha de frente ou da retaguarda. Esta categoria abrange todos os serviços que não se enquadram como serviços profissionais ou como serviços em massa.

c) Serviço em massa: atrelado a um alto volume de processamento de clientes, com baixa ou nenhuma customização, utiliza equipamentos para execução do serviço e com foco maior de atuação da retaguarda.

Dentre estas três categorias, o presente estudo se propõe a focar os serviços em massa procurando contribuir com as áreas do conhecimento relacionadas com à necessidade de descrever e analisar os processos de serviço, que apresentem um fluxo de processo mais padronizado (com pouca ou nenhuma customização), utilizem em maior grau equipamentos e tecnologia para execução do serviço e 
envolvam pouca interação entre funcionários da linha de frente e o cliente, mediante aplicação de técnicas de mapeamento de processo.

Nesta seção buscou-se contextualizar a área do conhecimento a ser abordada nesta dissertação de mestrado. Em seguida, são apresentadas a introdução ao tema de pesquisa, as questões de pesquisa, os objetivos gerais e específicos e a justificativa do estudo.

\subsection{TEMA DE PESQUISA}

Esta pesquisa se volta para o campo do conhecimento relacionado com 0 gerenciamento e controle dos processos de serviço, estuda as formas de mapeamento destes processos e tem como enfoque principal a participação do consumidor na execução das atividades dos processos consumo.

O consumidor como agente participante dos processos de serviço necessita ser considerado nos levantamentos, projetos e ações de melhoria das organizações de serviço. Suas tarefas necessitam ser mapeadas, medidas e controladas para que a visão e avaliação do processo de serviço seja mais abrangente. Para se compreender o processo de serviço é necessário considerar todos os agentes envolvidos que exerçam papel ativo para a sua concretização e o consumidor é um dos agentes que deve ser levado em conta, pois em muitos processos ele age não somente como demandante, mas também como executor de tarefas do processo para efetivação do consumo.

$\mathrm{O}$ advento do conceito de consumo lean trouxe a mensagem de que urge expandir o conceito de cadeia de valor, englobando as atividades desempenhadas pelo consumidor, ou seja, aplicando o Mapa de Consumo (WOMACK; JONES, 2006). Na mesma linha de argumentação, Gummesson (2008b) destaca em sua pesquisa a necessidade de estender o foco central das iniciativas de melhoria, deixando de analisar somente uma parte do processo e passando a considerar também a cadeia de valor do consumidor. 
Diante da crescente importância da participação do consumidor no processo de serviços e com o objetivo de melhor compreender como organizações provedoras de serviço podem avaliar e controlar o papel do consumidor como agente ativo (muitas vezes como co-produtor) na execução de atividades de consumo, esta pesquisa pretende explorar as formas de mapeamento e medição do esforço do consumidor.

Através do mapeamento, medição e análise das tarefas executadas pelos consumidores, as empresas podem identificar problemas existentes no processo do consumidor tais como dificuldades enfrentadas pelos consumidores para ter um serviço concretizado e pontos de estresse que causam um impacto negativo na percepção do consumidor. Desta forma, as organizações podem identificar oportunidades de melhoria em seus processos, em seus sistemas e na forma de capacitação e treinamento do próprio consumidor.

A adoção de ferramentas de mapeamento apresenta aspectos extremamente positivos que contribuem para a melhoria dos processos e para o aumento da competitividade da organização. À medida que a organização se preocupa com o desgaste e esforço de seus consumidores, promovendo ações de melhoria para facilitar o consumo e construir processos consistentes, alcança superioridade no mercado por oferecer maior satisfação e segurança aos seus consumidores.

Apesar das vantagens que a aplicação de melhorias das tarefas executadas pelos consumidores proporciona e da crescente percepção da qualidade dos serviços como vantagem competitiva organizacional, os consumidores ainda enfrentam dificuldades para obter o serviço da forma desejada. Com certa frequencia sofrem para conseguir obter o resultado esperado do serviço ou para solucionarem suas dúvidas e problemas junto às organizações provedoras dos serviços.

As ações de busca pela excelência ainda se encontram voltadas predominantemente aos processos das organizações envolvidos na cadeia de suprimentos, negligenciando a participação ativa do consumidor. As aplicações de ferramentas de mapeamento como mapa de processo, mapeamento do fluxo de valor (MFV) ou Value Stream Mapping (VSM), fluxograma (flowchart) estão comumente mais voltadas à análise dos fluxos das organizações tendo como motivação a redução de custos e aumento de lucro das empresas. Neste contexto, a 
forma de aplicação das ferramentas de mapeamento junto às organizações, por diversas vezes, apresentam deficiências no que se refere à visualização das tarefas desempenhadas pelo consumidor e análise do esforço e custo despendidos por ele.

Pressupõe-se que um dos motivos da escassez de aplicação do mapa de processo para as tarefas dos clientes está nos objetivos organizacionais que focam primordialmente o lucro, o aumento da eficiência e a redução dos custos internos.

Entretanto, o aumento da eficiência e redução de custos não são os únicos alicerces que movem as organizações. Em um ambiente altamente competitivo onde a qualidade é considerada um diferencial no mercado e onde se exige das organizações um papel mais participativo e contributivo na sociedade, proporcionar a satisfação dos clientes agregando maior valor ao serviço mostra-se uma exigência da sociedade e valor imprescindível para as organizações continuarem competitivas no mercado.

Portanto, mapear e medir as tarefas desempenhadas pelos consumidores é uma valiosa técnica para a melhoria de processos e agregação de valor para o consumidor que poderia, ainda, contribuir na construção de um diferencial competitivo para a organização. Entretanto, ainda são poucas as pesquisas que tratam da aplicação deste tipo de mapeamento. Diante disto, coloca-se o seguinte problema de pesquisa.

Problema: Ainda faltam casos práticos de aplicação que mostrem como mapear e avaliar efetivamente as tarefas dos consumidores em processos reais. Esta lacuna sugere a existência de restrições e dificuldades metodológicas para se mapear e medir a participação do cliente no processo de serviço.

A participação do consumidor no processo de serviço refere-se à dedicação deste no cumprimento da responsabilidade que Ihe é atribuída na execução das tarefas. Entende-se, portanto, que quanto maior a quantidade de tarefas demandadas ao consumidor, maior a participação e envolvimento deste no processo.

A construção do mapa de processo, quando aplicada nos processos internos das empresas ou em seus fornecedores pode contar com uma grande quantidade de 
informações, pois as mesmas se encontram dentro das organizações e os analistas que mapeiam o processo possuem acesso ao gemba - local onde as tarefas inerentes ao processo focado são realizadas. Desta forma, a empresa detém os dados necessários para a construção do mapa do processo e medição das tarefas executadas por seus funcionários. No caso do mapeamento das tarefas exercidas por fornecedores externos, os mesmos tendem a ceder os dados necessários como uma demonstração de parceria e comprometimento com a empresa cliente.

A empresa, portanto, quando executora das atividades a serem analisadas ou quando dependente de um fornecedor para levantamento de dados consegue executar as técnicas de mapeamento de processo de forma mais direta, mapeando e medindo o processo que necessita ser visualizado e eventualmente melhorado. Já quando o consumidor apresenta-se como agente participativo do processo - o que ocorre frequentemente em processos de serviço - as empresas podem encontrar dificuldades para a construção do mapa do processo e medição das tarefas desempenhadas pelos consumidores.

\subsection{QUESTÕES DE PESQUISA}

A partir do problema proposto e da lacuna identificada na literatura em relação à aplicabilidade das ferramentas de mapeamento de processo para visualização e medição das tarefas exercidas pelos consumidores em processos de serviço, faz-se necessário um melhor entendimento a respeito da adoção destas ferramentas.

As questões de pesquisa que norteiam este trabalho a fim de estudar a lacuna de conhecimento acerca do problema de pesquisa focado são apresentadas a seguir.

Questão 1 (Q1): Quais ferramentas propostas na literatura sobre a construção de mapas possibilitam evidenciar a participação do consumidor no processo de serviço?

Esta primeira questão direciona a pesquisa para a investigação da literatura que trata da participação do consumidor no processo de serviço, mais especificamente, 
para levantar as ferramentas existentes que poderiam ser aplicadas no mapeamento e medição da participação do consumidor na execução de processos de serviço.

As ferramentas para mapear e medir a participação do consumidor não são abordadas pela literatura e pelas empresas de forma tão extensa como ocorrem com as ferramentas tradicionais de mapeamento de processos que, por sua vez, focam as atividades inerentes às organizações e aos seus fornecedores.

Conforme explicitado no problema de pesquisa, devem existir dificuldades metodológicas para se aplicar as ferramentas de mapeamento e medição contemplando as tarefas desempenhadas pelos consumidores. Diante disto, este trabalho pretende explorar em profundidade estas possíveis dificuldades buscando responder as questões de pesquisa 2, 3 e 4.

\section{Questão 2 (Q2): Como as tarefas realizadas pelos consumidores durante o processo de serviço podem ser mapeadas?}

Pretende-se com esta questão entender como uma empresa poderia registrar as tarefas executadas pelo consumidor a fim de construir um mapa de processo que represente o fluxo de tarefas do consumidor.

Como descrito anteriormente na seção 1.1, as empresas estão habituadas a construir mapas das tarefas executadas por seus funcionários, pois os dados estão dentro da empresa ou fora dela, mas ao alcance da mesma. Por outro lado, quando o objetivo do mapa volta-se para identificação das tarefas executadas pelo consumidor, é necessário vislumbrar o processo do ponto de vista do consumo e envolver ou observar o consumidor no levantamento dos dados para construir um mapa de processo real.

A construção de um mapa que retrate as tarefas desempenhadas pelos consumidores pode ser utilizada pelas organizações em dois momentos distintos. Primeiramente, este tipo de mapeamento pode auxiliar no projeto do serviço, comparando o fluxo real do consumidor com o fluxo teórico que está sendo projetado pela empresa provedora do serviço. Em outro momento, o mapa de processo das atividades executadas pelos consumidores pode ser utilizado para 
avaliar processos de consumo já implantados, verificando suas possíveis variações de seu fluxo.

Além da identificação e registro do fluxo das tarefas do consumidor faz-se necessário medir seu esforço e satisfação para executar cada uma das tarefas que ficam sob o seu encargo, o que motiva a questão de pesquisa seguinte.

\section{Questão 3 (Q3): Como medir o esforço e a satisfação dos consumidores nas tarefas por eles desempenhadas durante o processo de serviço?}

$\mathrm{Na}$ área de serviços, tradicionalmente a atuação do consumidor é como cliente e demandante, requisitando a organização provedora do serviço que execute o processo para atender sua necessidade. Entretanto, as empresas identificaram no consumidor um potencial para terceirização de algumas de suas atividades e passaram a the atribuir responsabilidades pela execução de tarefas que antes pertenciam à organização. A participação do consumidor no processo é uma tendência crescente.

Esta atuação ativa do consumidor no processo cria a necessidade de medir sua participação. No presente trabalho, a participação do consumidor será medida através da mensuração de seu esforço e da sua satisfação na realização do processo. Para fins desta pesquisa, o esforço do consumidor será expresso em tempo gasto para execução das tarefas sob sua responsabilidade e que são necessárias para a concretização do serviço. Já a satisfação será considerada pelo estudo da percepção do consumidor em relação a sua participação no serviço.

O esforço do consumidor para execução das tarefas no processo de consumo do serviço pode ser mensurado por meio de diversas variáveis como gasto calórico (esforço físico), horas dedicadas para desenvolver determinada habilidade (aprendizagem), e grau de concentração necessária para executar a atividade (esforço mental). Estas variáveis podem variar e ser determinadas, inclusive, considerando-se o tipo de serviço que se pretende estudar. Para fins desta pesquisa optou-se por considerar o esforço do consumidor em termos do tempo gasto por este durante a execução do processo de consumo já que tal tempo é uma variável mensurável e existente em todos os processos de serviço que adotam o consumidor como co-produtor. Adicionalmente, pretende-se verificar o tempo que o analista 
responsável pelo mapeamento tem de dedicar e as dificuldades enfrentadas pelo mesmo para coleta de dados e construção do mapa do processo do consumidor.

\section{Questão 4 (Q4): Que dificuldades são encontradas no mapeamento da participação do consumidor no processo de serviço?}

Uma empresa que queira construir um mapa do processo do consumidor, ou seja, se prontifique em identificar e medir as tarefas executadas pelo consumidor, precisa, em primeiro lugar, selecionar qual ferramenta de mapeamento será utilizada para este fim.

No momento seguinte, dados deverão ser coletados para alimentar a ferramenta de mapeamento selecionada. Principalmente nesta fase de coleta de dados pressupõese que existem dificuldades em obter dados dos consumidores demandando dedicação, esforço e alocação de recursos da empresa para construir um Mapa de Consumo. Nesta pesquisa serão verificadas e registradas as dificuldades para se mapear e medir as tarefas dos consumidores com o objetivo de se construir um Mapa de Consumo. Tal construção, apesar de soar como uma simples aplicação de uma ferramenta de mapeamento, parece penosa e complexa, uma vez que sua aplicação não é usualmente encontrada na literatura ou nas empresas.

Desta forma, este trabalho visa identificar como as empresas podem mapear e medir as tarefas desempenhadas pelos consumidores e objetiva encorajar e difundir a utilização das ferramentas de mapeamento de processo para visualização e avaliação da participação do consumidor.

No Quadro 1 apresenta-se a estrutura dos capítulos e seções que compõem este trabalho onde são especificadas as seções dedicadas à discussão de cada uma das questões de pesquisa propostas. 
Quadro 1 - Relação das seções do trabalho atreladas às questões de pesquisa

\begin{tabular}{|c|c|c|c|}
\hline Capítulo & 1 & $\begin{array}{l}\text { Título do Capítulo } \\
\text { INTRODUÇÃO }\end{array}$ & \multirow{2}{*}{ Questão de Pesquisa } \\
\hline Capítulo & 2 & REFERENCIAL TEÓRICO & \\
\hline Seção & 2.1 & 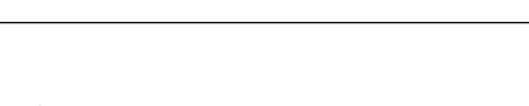 & $\begin{array}{l}\text { Q1: Quais ferramentas propostas na literatura sobre } \\
\text { a construção de mapas possibilitam evidenciar a } \\
\text { participação do consumidor no processo de serviço? }\end{array}$ \\
\hline Capítulo & 3 & MÉTODOS DE PESQUISA & \\
\hline Capítulo & 4 & $\begin{array}{l}\text { DESCRIÇÃO E ANÁLISE DO PROCESSO COM } \\
\text { INTERAÇÃO REMOTA }\end{array}$ & \\
\hline Seção & 4.1 & & $\begin{array}{l}\text { Q2: Como as tarefas realizadas pelos consumidores } \\
\text { durante o processo de serviço podem ser mapeadas? }\end{array}$ \\
\hline Capítulo & 5 & $\begin{array}{l}\text { DESCRIÇÃO E ANÁLISE DO PROCESSO } \\
\text { COM INTERAÇÃO PRESENCIAL }\end{array}$ & \\
\hline Seção & 5.1 & & \\
\hline Seção & 5.2 & & \\
\hline Capítulo & 6 & $\begin{array}{l}\text { DIFICULDADES ENFRENTADAS NA } \\
\text { CONSTRUÇÃO DO MAPA DO CONSUMO }\end{array}$ & $\begin{array}{l}\text { Q4: Que dificuldades são encontradas no } \\
\text { mapeamento da participação do consumidor no } \\
\text { processo de serviço? }\end{array}$ \\
\hline Capítulo & 7 & CONCLUSÕES & \\
\hline
\end{tabular}

Conforme se observa no Quadro 1, a questão 1 será tratada na seção 2.1 deste trabalho onde serão elencadas as ferramentas de mapeamento identificadas na literatura que possibilitam visualizar a participação do consumidor no processo de serviço. As questões 2 e 3 serão exploradas no Capítulo 4 para o tipo de serviço "faça você mesmo" com interação remota e no Capítulo 5 para o tipo de serviço "faça você mesmo" com interação presencial. Por fim, as dificuldades de mapeamento identificadas no desenvolvimento da pesquisa, conforme proposto pela questão 4, são tratadas no Capítulo 6 deste trabalho.

\subsection{JUSTIFICATIVA}

As empresas buscam aumentar a qualidade de seus processos e o valor percebido pelo cliente a fim de se manterem competitivas no mercado atual. Com o objetivo de alcançar eficiência em seus processos e agregar maior valor ao consumidor as empresas investem na aplicação de ferramentas para mapeamento e medição de 
seus processos bem como os de seus fornecedores, no entanto, negligenciam o papel do cliente como um agente participativo no processo de serviço.

A qualidade advém de todas as partes envolvidas no processo e não somente do provedor do serviço (Gummesson, 2008a), e verifica-se a necessidade de avançar no campo acadêmico através de estudos que avaliem o consumidor como um agente participativo no processo serviço e fonte para identificação de melhorias para o processo produtivo.

Desta forma, pretende-se verificar as ferramentas de mapeamento que possibilitem a visualização das tarefas executadas pelos consumidores e analisar como a identificação e medição de tais tarefas podem ser executadas em casos reais.

A relevância do tema apresentado reside, assim, no novo enfoque proposto, isto é, a busca do ponto de vista do cliente na melhoria de processos na área de serviços. $\mathrm{A}$ relevância da pesquisa centra-se, ainda, na premência de fornecer meios adequados às empresas para avaliarem o impacto de seus processos no cotidiano de seus clientes e realizarem ações consistentes de melhorias a este respeito.

\subsubsection{Valor do Serviço}

O valor do serviço é um conceito primordial para identificação das tarefas que representam ou não desperdícios no processo produtivo. O conceito de valor para o cliente pode estar atrelado ao que o mesmo está disposto a pagar (ANDERSON; JAINB; CHINTAGUNTAC,1992). No ramo de serviços este conceito deve ser considerado em conjunto com o esforço desempenhado pelo consumidor para a realização do serviço, uma vez que ele muitas vezes é envolvido no processo de serviço como co-produtor. "O custo de um serviço para um cliente é uma combinação do preço financeiro acompanhado do custo ou inconveniência de fazer a compra." (JOHNSTON; CLARK, 2002, p. 60).

Gummesson (2008b, p.15) atrela o valor à verdadeira utilidade do serviço ou produto para o consumidor, ou seja, o produto ou serviço não tem valor por si mesmo se não 
for utilizado pelo consumidor, suprindo suas necessidades. Para este autor, se o consumidor adquirir um bem ou serviço, mas não desfrutar do mesmo "seu dinheiro será desperdiçado".

Monroe (1991) define valor como a razão entre os benefícios e os sacrifícios percebidos pelo consumidor. O benefício atrela-se aos resultados alcançados com o serviço e a percepção do consumidor em relação à experiência do processo do consumidor, a qualidade do serviço prestado. O sacrifício percebido refere-se aos custos atrelados à compra de um bem ou serviço, como por exemplo, preço de aquisição e custos de transporte e de execução do pedido bem como os custos decorrentes da instalação, manutenção e risco de falha. Adicionalmente, Ravald e Gronroos (1996) enfatizam que uma das formas de agregar valor para o consumidor é reduz o sacrifício percebido pelo mesmo no processo do consumidor, o que the minimizaria o custo.

Neste conceito de agregação de valor através da redução do custo para o consumidor, Heskett, Sasser e Schlesinger (1997) definem o valor do serviço na perspectiva do cliente através das variáveis resultado do serviço, qualidade do processo, preço e custo, relacionadas na Equação 1:

$$
\text { Valor para cliente }=\frac{\text { Resultado }+ \text { Qualidade do processo }}{\text { Preço }+ \text { Custo }}
$$

As quatro variáveis consideradas nesta concepção são definidas a seguir.

- Resultado para o cliente: refere-se à saída final do serviço, a satisfação da necessidade do consumidor, ou, como expressado por Womack e Jones (2006), a resolução de seu problema. O resultado do serviço pode ser completamente atingido, parcialmente atingido ou não atingido. A avaliação desta variável está atrelada às necessidades e expectativas específicas do consumidor, que caracterizam a intangibilidade dos serviços.

- Qualidade do processo para o cliente: diz respeito ao processo do consumidor, a forma como o serviço é adquirido e experimentado pelo consumidor. O grau de contato e o grau de envolvimento do consumidor com 
o processo de serviço influenciam esta variável, que mede as implicações decorrentes da simultaneidade dos serviços,

- Preço para o cliente: é o preço que o cliente paga pelo serviço em si.

- Custo para o cliente: é o custo que o consumidor tem de assumir para conseguir adquirir um serviço. Pode estar atrelado à conveniência do serviço refletindo o tempo e esforço do consumidor para concretizar uma compra.

Por outro lado, Fitzsimmons e Fitzsimmons (2005) atrelam o conceito de valor ao custo da conveniência, ou seja, ao mínimo esforço do consumidor. No entanto, nem toda ação do consumidor pode ser considerada sacrifício, há atividades que fazem parte da experiência e são formas de participação "desejada" no processo do consumidor. Por este motivo, faz-se necessário levantar e analisar criticamente as tarefas desempenhadas pelo consumidor a fim de verificar o que é participação "desejada" e positiva e o que é sacrifício na visão do cliente.

Desta forma, este estudo busca verificar como as tarefas desempenhadas pelos consumidores podem ser mapeadas e visualizadas a fim de buscar melhorias consistentes para redução do tempo gasto pelo consumidor com tarefas que não agregam valor de forma a aumentar sua satisfação com o processo do consumidor.

\subsubsection{Concorrência no Mercado}

A crescente concorrência no mercado impulsiona as empresas a avaliar e melhorar seus processos para se manterem competitivas no mercado. No setor de serviços, a concorrência entre as organizações se intensificou no início dos anos 90 (MONTAGNER; BERNARDES; MATTEO, 1999) e apesar de ainda não ter atingido significativamente alguns ramos específicos deste setor no Brasil, tendências apontam para um crescimento na concorrência do setor terciário nos próximos anos (BRITO, 2008). A concorrência mostra-se um fator relevante que deve ser considerado para as organizações que pretendem se consolidar e se perpetuar no mercado criando valor para seus consumidores (KEEGAN; GREEN, 2000). 
Quando a empresa detém o monopólio sobre um mercado dificilmente investirá na melhoria dos processos e na agregação de maior valor ao serviço oferecido ao consumidor para retê-lo. Entretanto, quando forças competitivas ameaçam a empresa e o consumidor tem a opção de migrar de um serviço incômodo e oneroso para outro mais fácil, ágil e que agregue maior valor, a empresa se vê obrigada a investir na melhoria de seus processos e das interfaces existentes com o consumidor.

A facilidade de acesso dos consumidores aos fornecedores das empresas varejistas, a disponibilidade de ferramentas na web para consulta de informações a respeito dos produtos, serviços e integridade das empresas, o aumento da preocupação da sociedade com o meio ambiente, com a contribuição social e com a produção limpa, e o aumento da oferta de produtos e serviços iguais ou substitutos são alguns dos fatores que têm aumentado a concorrência entre as empresas e despertado a necessidade delas em investir na melhoria dos processos a fim de oferecer maior valor aos consumidores.

O aumento da concorrência no mercado, portanto, é um segundo elemento que justifica a relevância da pesquisa proposta. As empresas cada vez mais são cobradas por melhorias em sua eficiência operacional através da redução dos custos, retenção e aumento da base de clientes.

Através desta pesquisa pretende-se incentivar a aplicação das ferramentas de mapeamento e medição dos processos de consumo de serviço por empresas provedoras de serviços e, desta forma, contribuir para agregação de maior valor ao serviço entregue ao consumidor e para a melhoria da eficiência organizacional das empresas.

\subsection{OBJETIVO}

O principal objetivo desta pesquisa é verificar como as empresas podem identificar o esforço realizado e dificuldades enfrentadas pelo consumidor durante o processo do 
consumidor para poder apontar pontos de melhoria que possibilitem reduzir o esforço do mesmo.

Pretende-se assim, estimular a adoção de práticas de mapeamento do processo do consumidor para identificar as tarefas desempenhadas pelos consumidores e medir seu esforço na execução do processo de serviço. Nesta pesquisa o esforço do consumidor será expresso pelo tempo gasto pelo mesmo para realizar as tarefas sob sua responsabilidade.

\subsubsection{Objetivo Geral}

Este trabalho objetiva contribuir com o gerenciamento e controle das operações de serviço no que tange às abordagens de melhoria de processos, verificando como a participação do consumidor nos processos de serviço pode ser mapeada e medida. Tem-se como premissa que o mapeamento e a medição dos processos auxiliam na visualização de oportunidades para melhorar o fluxo e aumentar o valor agregado no serviço oferecido aos consumidores.

\subsubsection{Objetivos Específicos}

A fim de alcançar o objetivo geral desta pesquisa apresentam-se os seguintes objetivos específicos:

a) Verificar como a literatura propõe a construção de mapas para visualizar as tarefas executadas pelos consumidores em processos de serviço.

b) Aplicar o Mapa de Consumo em casos reais de serviço. Detalhar como a construção deste mapa pode ser conduzida, identificando e medindo as tarefas desempenhadas pelos consumidores. 
c) Identificar as principais dificuldades encontradas na construção do Mapa de Consumo e medição das tarefas dos consumidores.

\subsection{DELIMITAÇÃO DO ESCOPO}

Os processos de serviço apresentam variações em relação a diversas variáveis como grau de padronização, envolvimento do cliente, automatização, volume e complexidade. Em processos de serviço, o encontro de serviço pode ocorrer de diversas formas: o consumidor face-a-face com o funcionário da organização, por meio de um contato telefônico, o consumidor tela a face no contato por meio de um sistema, uma máquina ou um site.

Estas variações na forma de execução dos processos de serviço caracterizam as distintas formas de processo que serão exploradas neste capítulo a fim de delimitar o escopo da pesquisa.

Uma forma de classificação dos processos de serviço está atrelada à variabilidade ou flexibilidade do processo. Johnston e Clark (2002) apresentam uma classificação dos processos de serviço que permite identificar o grau de variação presente no processo, caracterizando-os como: rotineiros, repetidos ou estranhos.

Os processos rotineiros são de alto volume e alta padronização com baixa variação na execução do processo. A demanda é relativamente previsível o que possibilita o planejamento mais eficiente para alocação dos recursos necessários e pode justificar o investimento em automação das atividades. A prestação do serviço não é customizada, seguindo sempre a mesma sequência de tarefas com o objetivo de atingir um resultado padronizado.

Os processos repetitivos diferem dos rotineiros por apresentarem um volume menor e um maior grau de variedade do serviço, o que nem sempre justifica a automação do processo. Em contrapartida, a empresa oferece maiores opções para os clientes e há uma maior flexibilização no processo produtivo. 
Nos processos estranhos a empresa lida com atividades novas e não padronizadas, que são iniciadas geralmente com volumes baixos e cuja demanda é de difícil previsão o que dificulta também o planejamento dos recursos necessários. Quanto maior a familiaridade da organização em lidar com processos deste tipo, mais flexível será a mesma podendo customizar seus serviços às necessidades dos clientes.

Esta pesquisa focará os processos rotineiros, nos quais existe maior grau de padronização e as tarefas executadas tendem a seguir uma mesma sequência lógica e temporal.

Os processos de serviço ainda podem ser classificados conforme as seguintes categorias: projetos de serviço, parceria de serviço, fábrica de serviço e serviço "faça você mesmo". Nesta forma de categorização considera-se a variedade do processo e o grau de envolvimento do cliente. O envolvimento do cliente está atrelado à coparticipação deste na execução do processo de serviço, enquanto o grau de contato denota a interação entre empresa e consumidor.

Vale ressaltar que o alto envolvimento do cliente no processo de serviço está relacionado à responsabilidade que lhe é atribuída para a concretização do serviço. A participação do consumidor no processo pode acarretar uma alta ou baixa alocação de tempo e recursos pelo consumidor, mas o seu grau de envolvimento está associado às tarefas que Ihe são atribuídas na execução do processo de consumo do serviço.

Na Figura 4 são posicionadas estas quatro categorias de serviço relacionando-as à variabilidade dos processos - rotineiros, repetidos e estranhos - e ao grau de envolvimento do cliente. 


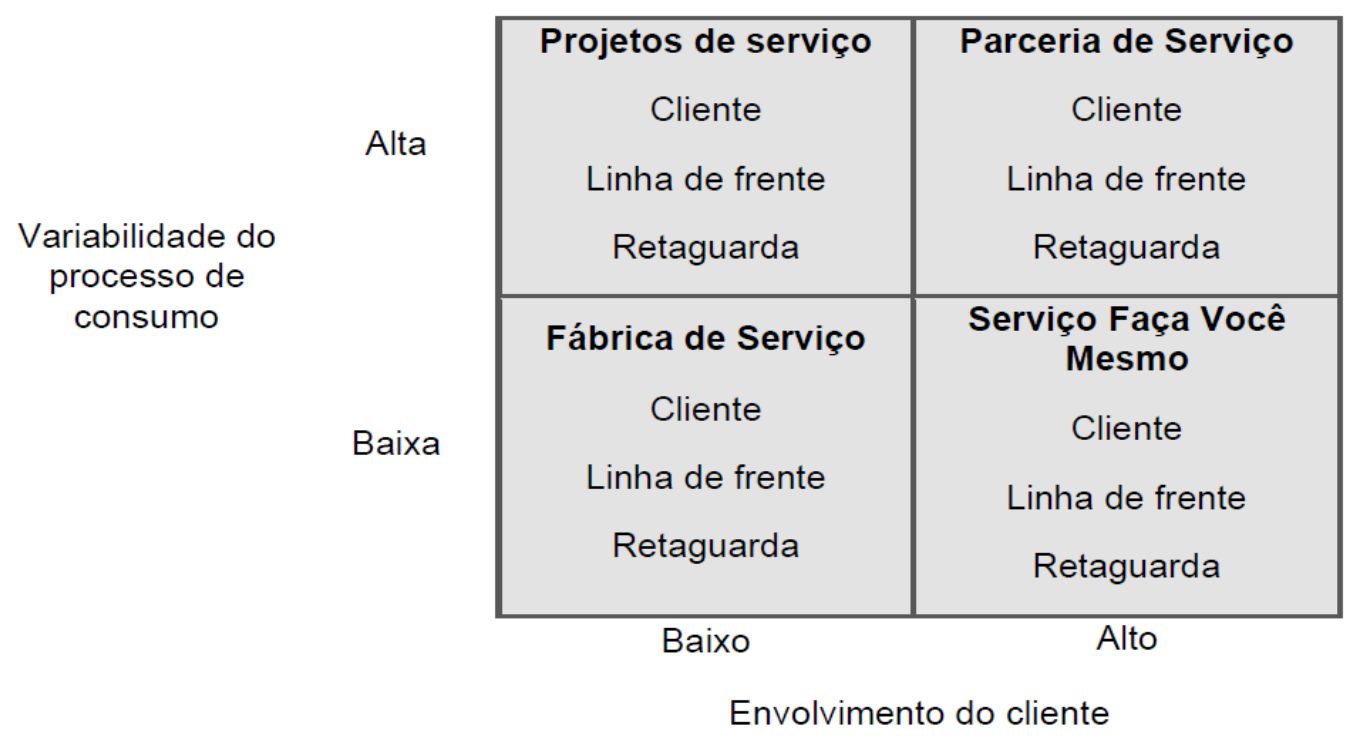

Figura 4 - Matriz das áreas de decisão-chave

Fonte: baseada em Larsson e Bowen (1989); Clutterbuck et al. (1993) apud Johnston e Clark (2002, p.206)

Cada categoria de serviço contemplada pela Figura 4 é caracterizada a seguir:

(i) Projetos de Serviço: estão atrelados a processos estranhos, com baixo envolvimento do cliente. O cliente participa como demandante do serviço e as atividades são executadas pela linha de frente (Front Office) e retaguarda (Back Office). A linha de frente deve ser flexível e apresentar habilidades combinadas para ser capaz de atuar tanto junto ao cliente como junto à retaguarda para trazer a solução adequada. Exemplos deste tipo de serviço são empresas que realizam pesquisa de mercado e desenvolvedores de sistemas de informação.

(ii) Parceria de Serviço: está atrelada a processos estranhos e repetitivos e envolve alta participação do cliente e da linha de frente. Os serviços ocorrem durante a interação do cliente com a linha de frente. Neste processo o cliente desenvolve o serviço em conjunto com a empresa e o serviço é customizado para atender suas necessidades e expectativas. Isto pode ser observado em processos como reforma de imóveis, em serviços financeiros específicos onde exista uma customização para 
atender o cliente, ou em empresas de design que desenvolvem logotipos ou propagandas.

(iii) Fábrica de Serviço: está atrelada aos processos de consumo rotineiros e repetitivos de alto volume e baixa variabilidade. Ocorre uma baixa participação do cliente e a maior parte da atividade é executada pela retaguarda. Este tipo de serviço ocorre, por exemplo, em diversas empresas de varejo, restaurantes e serviços financeiros. Tais serviços costumam ser padronizados e elegíveis a passarem à categoria de "faça você mesmo".

(iv) Serviço "Faça Você Mesmo": está atrelado aos processos de consumo rotineiros e repetitivos, com alta participação do cliente na execução das atividades o que o faz atuar como co-produtor do serviço. Exige participação do cliente, da linha de frente e da retaguarda para execução eficaz do serviço. Nestes processos são comuns as interfaces eletrônicas entre empresa e cliente onde a linha de frente é um sistema ou uma máquina e os clientes interagem com os mesmos. Exemplos deste tipo de serviço são os caixas eletrônicos, a compra de produtos pelas máquinas de auto-serviço que disponibilizam comidas e bebidas prontas, as compras realizadas pela internet.

A Tabela 1 apresenta um resumo comparativo destas quatro categorias de serviço de acordo com as variáveis volume, customização, tipo de processo e os graus de envolvimento do cliente, da linha de frente (Front Office) e da retaguarda (Back Office). 
Tabela 1 - Comparação entre as categorias de serviços

\begin{tabular}{lcccc}
\hline & $\begin{array}{c}\text { Fábrica de } \\
\text { serviço }\end{array}$ & $\begin{array}{c}\text { Serviço “faça } \\
\text { você mesmo" }\end{array}$ & $\begin{array}{c}\text { Projetos de } \\
\text { Serviço }\end{array}$ & $\begin{array}{c}\text { Parceria de } \\
\text { serviço }\end{array}$ \\
\hline Volume & Alto & Alto & Baixo & Baixo \\
\hline $\begin{array}{l}\text { Customização de } \\
\text { serviços }\end{array}$ & Baixa & Baixa & Alta & Alta \\
\hline $\begin{array}{l}\text { Tipo de processo } \\
\text { Rotineiros / }\end{array}$ & $\begin{array}{c}\text { Rotineiros / } \\
\text { repetidos }\end{array}$ & $\begin{array}{c}\text { Estranhos / } \\
\text { repetidos }\end{array}$ & $\begin{array}{c}\text { Estranhos / } \\
\text { repetidos }\end{array}$ \\
\hline $\begin{array}{l}\text { Envolvimento do } \\
\text { cliente }\end{array}$ & Baixo & Alto & Baixo & Alto \\
\hline $\begin{array}{l}\text { Envolvimento da } \\
\text { Linha de Frente }\end{array}$ & Baixo & Alto & Alto & Alto \\
\hline $\begin{array}{l}\text { Envolvimento da } \\
\text { retaguarda }\end{array}$ & Alto & Alto & Alto & Baixo \\
\hline
\end{tabular}

Fonte: baseada em Johnston e Clark (2002, p. 205 a 209)

Conforme citado anteriormente esta pesquisa busca avaliar processos de natureza mais rotineiras, por apresentarem maior grau de padronização e estarem sujeitos a menor variabilidade. Ademais, pretende-se avaliar processos em que o cliente tem de exercer um papel mais participativo na execução do processo de serviço. Por estas razões, a categoria de serviço que melhor se adéqua à pesquisa é a dos serviços "faça você mesmo", na qual o cliente é o principal agente que executa as atividades para consumação da compra e execução do serviço.

Nos processos "faça você mesmo" a empresa participa oferecendo os recursos sistêmicos e a infraestrutura necessária para execução das atividades, além de orientar o cliente a respeito de como executar cada tarefa. Os funcionários da empresa geralmente não entram em contato direto com o cliente e não influenciam a sua percepção em relação ao resultado do serviço e ao valor agregado no serviço. Para executar as atividades neste tipo de processo o cliente necessita de conhecimento e habilidades que o façam compreender exatamente o que deve ser feito para atingir o resultado desejado. "Grande carga de trabalho pode ser alocada sob a responsabilidade do cliente se este tiver habilidades e informações adequadas sobre seu papel" (TORRES JUNIOR, 2007, p. 44). 
Desta forma, pretende-se estudar processos onde o cliente é um agente altamente participativo, envolvido no processo de serviço e responsável pela execução das atividades inerentes ao processo. Pretende-se ainda com a escolha da categoria de serviço "faça você mesmo" isolar o grau de satisfação e valor percebido pelo consumidor decorrente de um bom atendimento do funcionário da organização e ao mesmo tempo tornar a medição do esforço do consumidor tangível através da quantificação do tempo despendido pelo mesmo.

Os serviços podem ainda ser categorizados em relação aos seus fluxos como (i) processo único, quando na execução de um processo de um consumo o cliente adquire um serviço de cada vez ou (ii) múltiplos processos, quando em um mesmo fluxo o cliente adquire e experimenta diversos serviços simultaneamente (paralelamente) ou encadeia uma sucessão de diversos serviços.

O processo único refere-se aos casos em que o cliente lida com um serviço por vez, ou seja, o tempo do consumidor é dedicado somente a um serviço, como ocorre no processo de impressão de exames médicos pela internet nos quais o cliente digita um código de identificação e uma senha, visualiza e imprime os exames e finaliza o acesso; no processo em que o cliente agenda a inspeção veicular anual para o seu carro através do site de agendamento com a informação de um automóvel por vez ${ }^{1}$; no processo em que o cliente assiste a um filme no cinema ou quando o cliente usa um taxi para se deslocar de um lugar para o outro.

Nos casos de múltiplos processos o fluxo de consumo torna-se ramificado e/ou progressivamente emendado e o controle sobre as atividades do cliente torna-se mais difícil, pois diversos serviços podem ser consumidos ao mesmo tempo ou em um mesmo acesso do cliente ao sistema do provedor. Esta classificação de processo de consumo não está associada à ideia de divergência de fluxo proposta por Shostack $(1987)^{2}$, mas a possibilidade de execução de diferentes serviços em um único acesso ao provedor. Pode-se exemplificar estas situações quando o consumidor acessa sua conta de banco via internet podendo combinar a realização de diversos serviços em um mesmo acesso, ou quando vai ao cabeleireiro e no seu atendimento diversos serviços são realizados de forma simultânea. O mapeamento

\footnotetext{
${ }^{1}$ Como no caso do serviço de agendamento disponibilizado pela Controlar no município de São Paulo.

2 O conceito de divergência de fluxo será tratado adiante na seção 2.1.2
} 
e a medição destes tipos de processo são mais complexos. Esta complexidade aumenta à medida que o fluxo se torna mais ramificado e a quantidade de serviços demandados numa mesma oportunidade aumenta.

Estes tipos de processo de serviço são ilustrados de maneira geral pela Figura 5 na qual se verifica o contraste entre o fluxo dos serviços com processo único e o fluxo dos serviços de múltiplos processos combinados em um mesmo acesso ao sistema do provedor ou ao fornecedor.

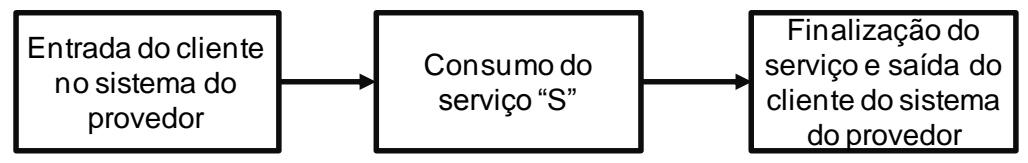

(a) Processo único

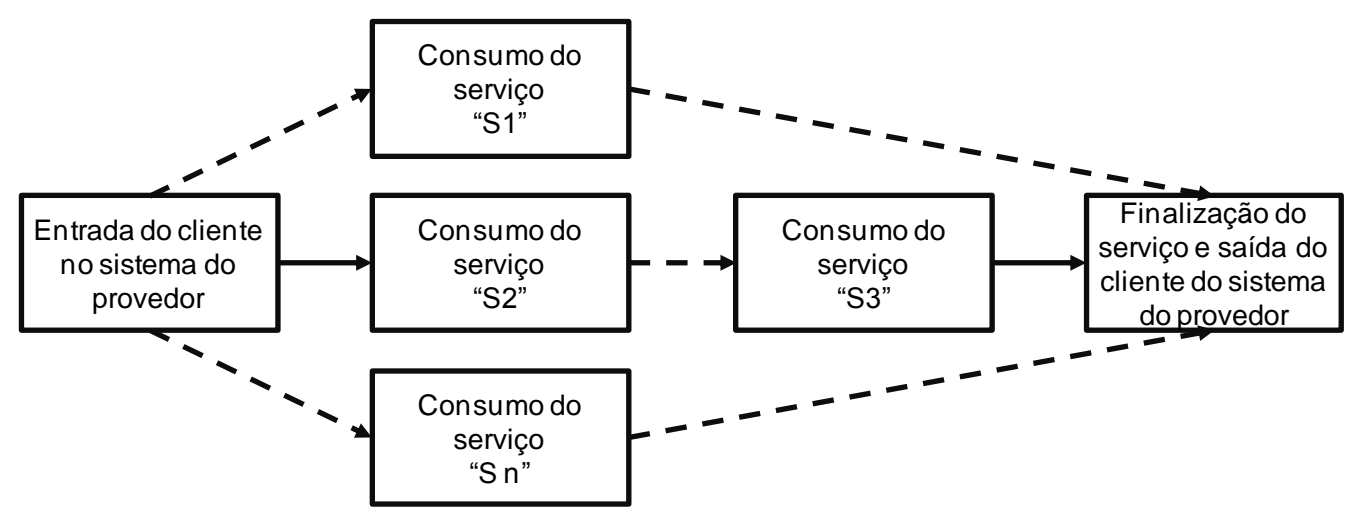

(b) Múltiplos processos

Figura 5 - Tipos de processo de serviço

Os serviços "faça você mesmo" podem, ainda, ser divididos em relação à forma de interação entre empresa e consumidor que pode ser remota ou presencial.

Fitzsimmons e Fitzsimmons (2005) classificam o serviço presencial, em que o cliente fica face-a-face com os funcionários da empresa prestadora do serviço, como tradicional e classificam como encontros remotos os serviços eletrônicos que podem ocorrer sem interação (quando o cliente executa o serviço por meio de uma máquina, sistema ou pela internet) ou com interação indireta (quando o cliente entra 
em contato com um funcionário da empresa através de um canal de comunicação como telefone, e-mail ou chat).

Apesar dos autores atrelarem o serviço presencial ao encontro face-a-face entre consumidor e funcionário, o serviço presencial pode abranger também os serviços nos quais o consumidor se desloca até o provedor para executar uma atividade tela a face. Isto ocorre, por exemplo, quando o cliente utiliza um recurso de sistema, como uma máquina de autoatendimento para check in no aeroporto e em caixa eletrônico numa agência bancária.

Os serviços com alto envolvimento do consumidor, portanto, podem ocorrer tanto presencialmente como remotamente. Fitzsimmons e Fitzsimmons (2005) consideram oito variáveis para análise dos processos tradicionais (presenciais) e eletrônicos (remotos): tipo de interação, encontro, disponibilidade, acesso, área de mercado, ambiente, diferenciação competitiva e privacidade. Estas variáveis são utilizadas na Tabela 2 para caracterização dos serviços que se enquadram como "faça você mesmo" e "fábrica de serviço" os quais envolvem alta participação dos consumidores. 
Tabela 2 - Características dos serviços "Faça você mesmo" e "Fábrica de serviço"

\begin{tabular}{|c|c|c|c|c|}
\hline \multirow{2}{*}{$\begin{array}{l}\text { Critério } \\
\text { Tipo de Interação }\end{array}$} & \multicolumn{2}{|c|}{$\begin{array}{c}\text { Serviço "Faça você mesmo" } \\
\text { (sem interação) }\end{array}$} & \multicolumn{2}{|c|}{$\begin{array}{l}\text { Fábrica de serviço } \\
\text { (com interação) }\end{array}$} \\
\hline & Remoto & Presencial & Remoto & Presencial \\
\hline Encontro & Tela a face & Tela a face & $\begin{array}{l}\text { Tela a face ou } \\
\text { telefone a face }\end{array}$ & Face-a-face \\
\hline Disponibilidade & Qualquer hora & $\begin{array}{l}\text { Variações de } \\
\text { alternativas de } \\
\text { horários } \\
\end{array}$ & $\begin{array}{l}\text { Variações de } \\
\text { alternativas de } \\
\text { horários }\end{array}$ & $\begin{array}{c}\text { Horas de } \\
\text { trabalho } \\
\text { padrão }\end{array}$ \\
\hline Acesso & De casa & $\begin{array}{c}\text { Deslocamento } \\
\text { para o local }\end{array}$ & De casa & $\begin{array}{c}\text { Deslocamento } \\
\text { para o local }\end{array}$ \\
\hline Área de mercado & Todo mundo & Local & Todo mundo & Local \\
\hline Ambiente & $\begin{array}{l}\text { Interface } \\
\text { eletrônica }\end{array}$ & $\begin{array}{c}\text { Ambiente físico } \\
\text { e interface } \\
\text { eletrônica } \\
\end{array}$ & $\begin{array}{l}\text { Interface } \\
\text { eletrônica }\end{array}$ & Ambiente físico \\
\hline $\begin{array}{l}\text { Diferenciação } \\
\text { competitiva }\end{array}$ & Conveniência & Agilidade & Personalização & Personalização \\
\hline Privacidade & Anonimato & Anonimato & Interação social & $\begin{array}{l}\text { Interação } \\
\text { social }\end{array}$ \\
\hline
\end{tabular}

Fonte: critérios de comparação adaptados de Fitzsimmons e Fitzsimmons (2005, p.185)

Fábrica de Serviço com interação presencial: refere-se ao contato direto e presencial entre consumidor e funcionário da empresa, ocorrendo interações e troca de informações entre as partes envolvidas no processo. Trata-se de um encontro complexo influenciado pelo ambiente, pelas necessidades e experiências prévias do consumidor e pela capacidade e autonomia dos funcionários da linha de frente.

Fábrica de Serviço com interação remota: denominado encontro por telefone por Johnston e Clark (2002), este tipo de interação pode ocorrer por outros meios de comunicação como chat e e-mail. Trata-se de uma interação direta entre funcionário e consumidor, porém ocorrendo a distância. Em encontros de serviço desse tipo a percepção e avaliação do cliente em relação ao processo de serviço são fortemente influenciadas pela interação com o funcionário da empresa provedora do serviço. 
Essencialmente, apresentam um custo operacional menor para a empresa e visam oferecer maior conveniência e facilidade de acesso ao cliente.

Serviço "Faça Você Mesmo" com interação remota: o contato entre o cliente e o provedor ocorre sem interação direta e usual entre funcionários e consumidores, por meio de recursos como sistemas computadorizados, máquinas, internet. Neste tipo de processo, principalmente na adoção de negócios eletrônicos através de sistemas computadorizados e da internet, o cliente tem um alto grau de envolvimento na execução do processo de serviço, ou seja, atua como co-produtor e com maiores responsabilidades sobre o processo do que nos serviços com interação presencial.

Serviço "Faça Você Mesmo" com interação presencial: neste tipo de serviço o cliente interage com a empresa através de sistemas computadorizados e/ou máquinas, porém a execução do processo ocorre dentro da empresa com o deslocamento do cliente até um local determinado. A execução do serviço é afetada pelo horário de disponibilidade da organização e pelo ambiente físico. O cliente tem um alto grau de envolvimento e atua como co-produtor.

Este estudo foca, portanto, os processos da categoria "faça você mesmo" no qual existe uma baixa variabilidade do processo e um alto envolvimento do cliente. $O$ escopo delimita-se, ainda, nos serviços com processo único, nos quais um único serviço é adquirido e executado de cada vez reduzindo-se a complexidade de avaliação do fluxo de consumo. Por fim, serão considerados nesta pesquisa os dois tipos de interação entre provedor e cliente: remota e presencial. Na Figura 6 tem-se o resumo das características do processo de serviço que são consideradas na delimitação do escopo desta pesquisa. 


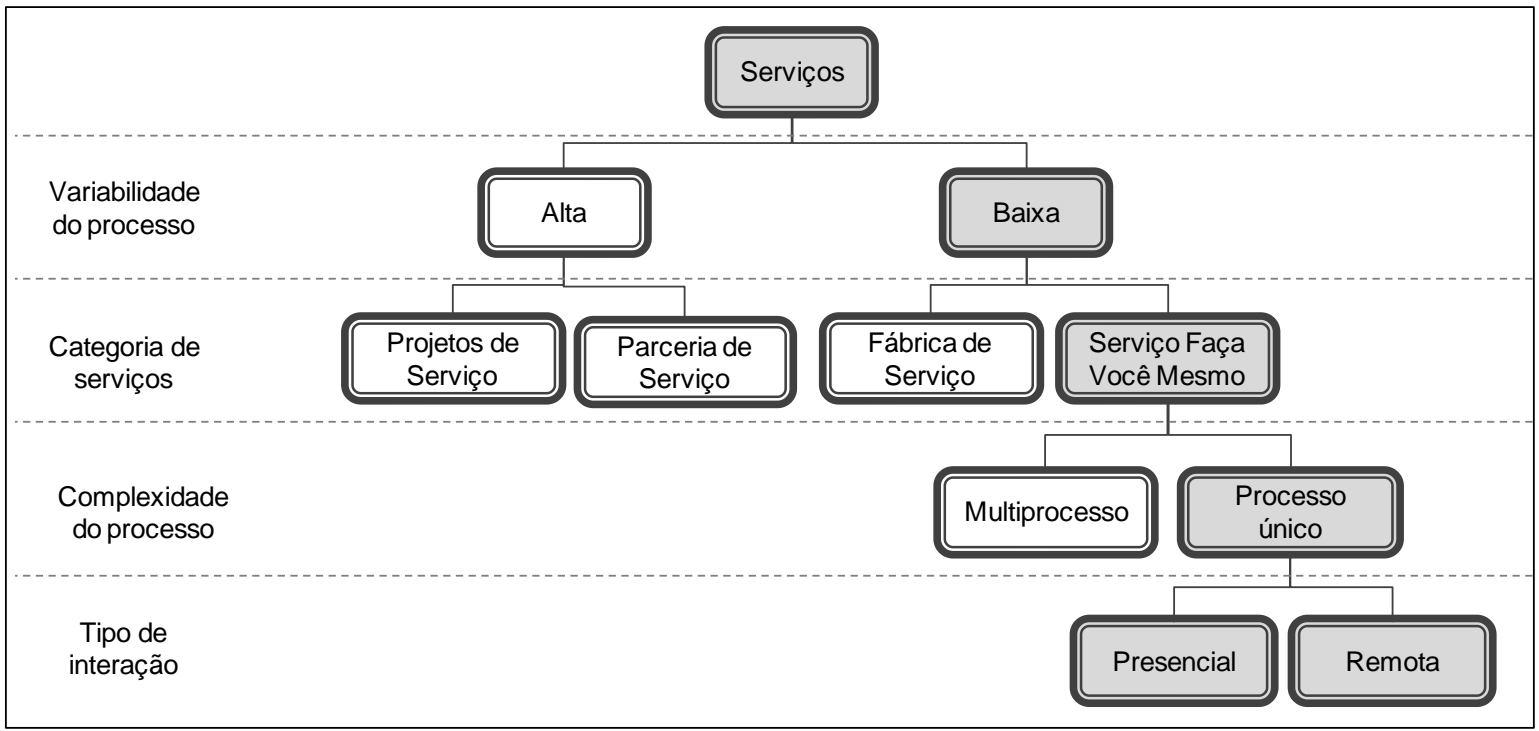

\section{Legenda}

$\square$ Dentro do escopo de pesquisa

$\square$ Fora do escopo de pesquisa

Figura 6 - Delimitação do escopo da pesquisa 


\section{REFERENCIAL TEÓRICO}

O mapeamento e medição das tarefas desempenhadas pelos consumidores durante o processo de serviço é uma técnica que poderia ser utilizada pelas organizações para melhoria dos seus processos produtivos e aumento da competitividade agregando maior valor aos clientes.

Tendo como premissa a concepção formulada pela equação de valor percebido pelo cliente definido por Heskett, Sasser e Schlesinger (1997) descrita na seção 1.4.1, ao reduzir o preço pago pelo produto ou serviço ou ao reduzir o custo para o cliente no processo do consumidor aumenta-se o valor percebido.

A satisfação do consumidor com um serviço depende do valor agregado pelo mesmo e, portanto, depende também do custo e tempo dedicado ao consumo do serviço. Diante disto, a empresa não pode se limitar a considerar somente o que provê ao consumidor para garantir sua satisfação, mas deve também concentrar seus esforços em avaliar as atividades executadas pelo próprio consumidor para a concretização do serviço.

"Se a empresa prover valor ao consumidor em termos de redução do sacrifício percebido pelo cliente, reduzindo os custos a serem despendidos e melhorando o desempenho do consumidor, as chances de sucesso da empresa são evidentes." (RAVALD; GRÖNROOS, 1996, p. 21).

Para reduzir o sacrifício do consumidor e melhorar o desempenho do consumidor no processo de serviço a empresa deve entender os elementos percebidos por ele, ou seja, o que contribui com a percepção positiva ou negativa do valor do serviço.

Ressalte-se que as atividades desempenhadas pelo consumidor durante o processo de serviço não são sempre consideradas um sacrifício, ao contrário, em muitos casos o consumidor aprecia o seu envolvimento e participação. $O$ valor do serviço, portanto, está atrelado aos benefícios percebidos pelo consumidor em comparação com os custos que ele tem de despender. 
Neste sentido, o desafio do gerenciamento das operações de serviço está em maximizar o benefício para o cliente, minimizar o custo financeiro e o sacrifício para o cliente e minimizar o custo para a organização (JOHNSTON; CLARK, 2002).

Através da identificação do valor do serviço e do mapeamento e medição das tarefas desempenhadas pelo consumidor é possível analisar os desperdícios existentes no processo - tarefas ou parte das tarefas que não agregam valor - e buscar sua eliminação ou redução.

O custo do serviço para o cliente pode estar relacionado à conveniência de deslocamento; ao esforço, retrabalho e dificuldades que tem de enfrentar para adquirir o serviço; ao tempo dedicado ao processo do consumidor; e aos recursos que precisa dispor para consumir o serviço. Para se medir o esforço do consumidor, variáveis mensuráveis como o custo para execução do processo de serviço dinheiro gasto com recursos e não com o preço pago pelo serviço em si - e o tempo despendido no processo do consumidor podem ser considerados.

Entender com profundidade a forma como os consumidores vivenciam e avaliam o processo de serviço é um dos muitos desafios enfrentados pelas empresas que projetam, entregam e ofertam serviços (BITNER; OSTROM; MORGAN, 2008).

Apesar da ideia de aplicação das técnicas de mapeamento de processo para visualização e medição das tarefas desempenhadas pelos consumidores ser aparentemente vantajosa para as organizações, estas parecem não perceber seus benefícios e não se empenham em aplicar estas técnicas que focam o esforço do cliente.

O provedor de um serviço deve garantir que o consumidor receba as informações corretas e no momento adequado para garantir uma entrega consistente em relação ao que for demandado (LOCHER, 2011).

Locher (2011) propõe a aplicação dos princípios lean nos processos de serviço e considera que o consumidor pode participar na eliminação de problemas através de sua opinião e vivência no processo. Entretanto, esta aplicação da filosofia lean em serviços, que preconiza a promoção do Lean Office, não considera a necessidade de mapear e medir as tarefas desempenhadas pelo consumidor enquanto agente 
participante do processo de serviço, limitando-se a focar os processos administrativos das próprias organizações.

Com o objetivo de verificar a abrangência da adoção das ferramentas de mapeamento para visualização e medição das atividades dos consumidores, foi realizada uma revisão da literatura.

Através da revisão da literatura esta pesquisa pretende esclarecer se a questão do mapeamento e medição das atividades dos consumidores está sendo abordada no contexto acadêmico e caso afirmativo, como tem sido considerada.

Para realização desta revisão da literatura publicações técnicas e científicas relacionadas com este assunto foram buscadas nas bases de publicações Scopus, ProQuest, ISI Web of Knowledge - Web of Science e Emerald. Nesta busca foram consideradas as duas categorias de trabalhos descritas a seguir:

a. Trabalhos sobre o Mapa de Consumo ou Blueprint em serviços: a fim de pesquisar trabalhos publicados relacionados ao mapeamento e medição das atividades dos consumidores. Nesta forma de busca, foram utilizadas as seguintes expressões: "consumption map", "lean consumption", "lean solution", "measuring clients", "service blueprint".

A consideração das expressões "consumption map", "lean consumption" e "lean solution" teve como propósito identificar trabalhos que contemplassem a ferramenta de Mapa de Consumo proposta por Womack e Jones (2006).

Já a consideração da expressão "measuring clients" teve o objetivo de identificar trabalhos que medissem o esforço do consumidor durante a execução do processo de serviço enquanto a consideração da expressão "service blueprint" buscou agregar à pesquisa os trabalhos que utilizassem a ferramenta de mapeamento Blueprint em processos de serviço.

b. Trabalhos sobre o Mapa de processo ou VSM em serviços: a fim de pesquisar os trabalhos publicados relacionados ao mapeamento de processos em serviços. Nesta forma de busca foram utilizadas as seguintes expressões: "process mapping" em conjunto com as palavras "service" e "VSM" (Value Stream Mapping) em conjunto com "service". 
A consideração da expressão "process mapping" em conjunto com a palavra "service" teve como propósito identificar trabalhos que contemplassem ferramentas de mapeamento em processos de serviço aplicadas ao mapeamento tradicional adotado nas organizações para visualizar as atividades executadas pela empresa provedora do serviço.

A consideração da expressão "VSM" em conjunto com "service" teve como objetivo identificar trabalhos que aplicassem a ferramenta de Mapeamento do Fluxo de Valor (MFV) - denominação em português de Value Stream Mapping (VSM) - em serviços. O MFV é abordado na literatura sobre o mapeamento de processos como um meio que auxilia a visualização da situação atual de um dado processo e a identificação de desperdícios, facilitando, inclusive, a elaboração do desenho de fluxos de processos futuros mais racionalizados que possam ser estabelecidos pela implementação das oportunidades de melhorias identificadas (ROTHER; SHOOK, 2008). O uso do MFV tem sido difundido por adeptos da filosofia lean por constituir uma ferramenta relevante para a identificação de oportunidades para realização de melhorias nos processos de forma a minimizar as atividades que não agregam valor ao cliente.

O levantamento realizado levou em consideração os artigos publicados entre 2000 e 2011 disponíveis em meio eletrônico nas bases de busca consideradas. As expressões selecionadas para pesquisa foram buscadas nos campos tópico, resumo, palavra-chave e título.

Os retornos das bases de pesquisa foram analisados criticamente verificando-se 0 título dos trabalhos e, quando necessário, o resumo para se verificar a real aderência do resultado encontrado ao tema de pesquisa proposto.

Artigos que não apresentaram relação ao tema da pesquisa, como, por exemplo, o estudo de fontes de energia e consumo de carbono, provenientes das buscas com as expressões "consumption map", "lean consumption", "lean solution", foram descartados.

O Gráfico 1 apresenta o resultado do levantamento da literatura identificada segregado por base de publicação. 


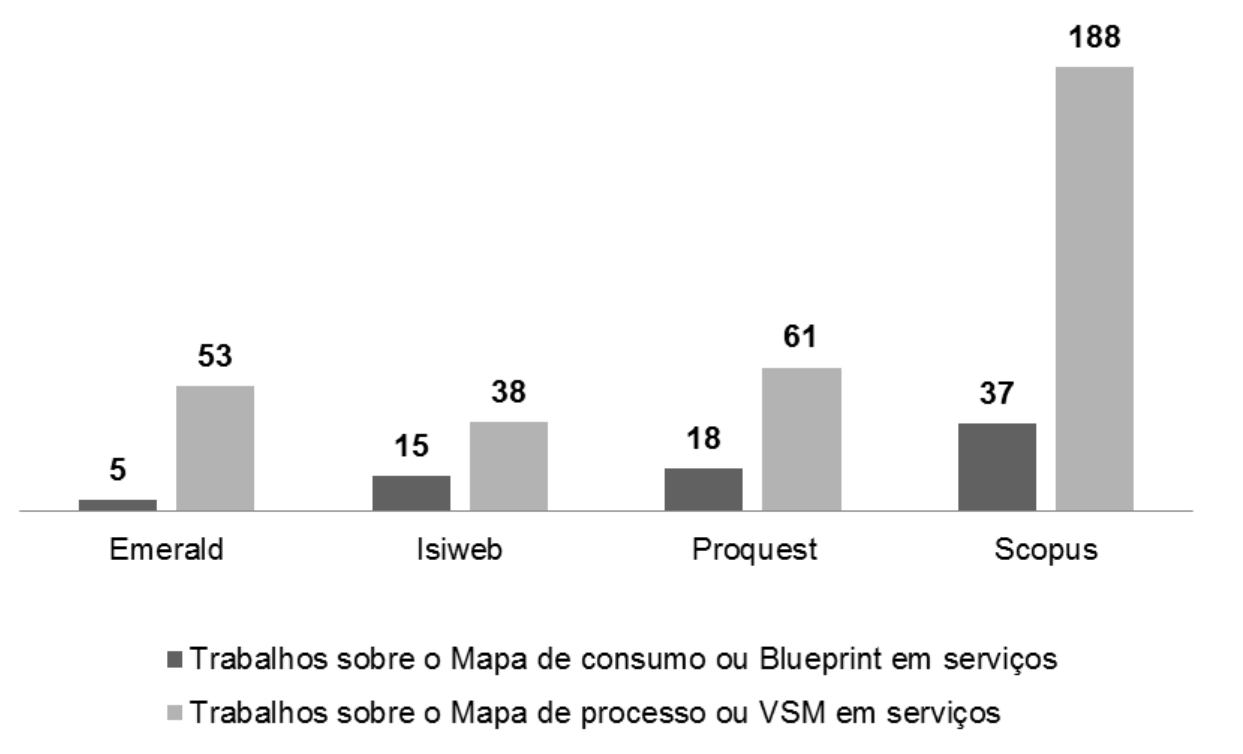

Gráfico 1 - Distribuição dos artigos levantados por base de publicação

O levantamento por bases de publicação resultou no montante de 415 artigos relacionados às expressões consideradas, dos quais 75 relacionam-se aos trabalhos sobre o Mapa de Consumo ou Blueprint em serviços e 340 tratam de trabalhos sobre o mapa de processos ou VSM em serviços.

Verificando-se um a um os artigos levantados foi constatado que muitos artigos estavam catalogados em mais de uma das bases de publicações que foram pesquisas. Para obtenção da quantidade de publicações únicas levantadas, os artigos foram então contados sem repetição. O Gráfico 2 ilustra os resultados das quantidades apuradas por ano de publicação.

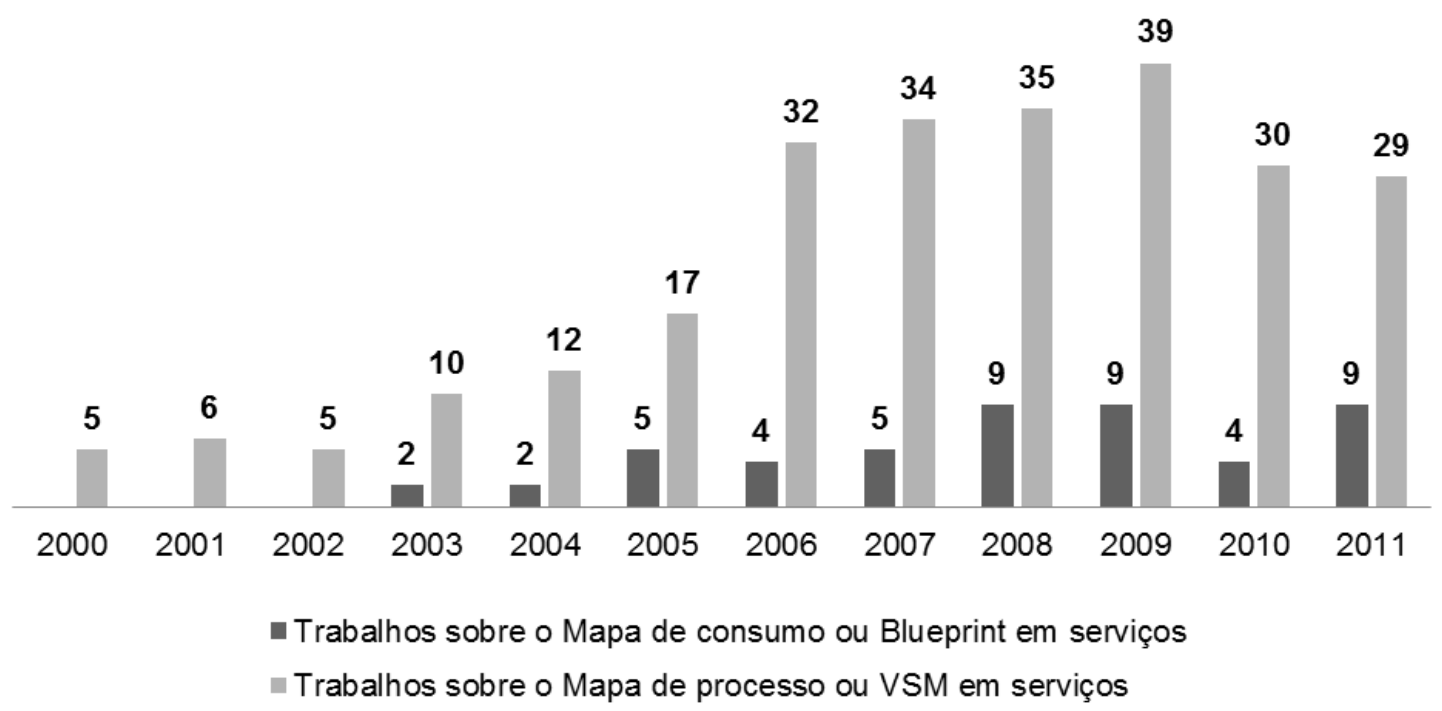

Gráfico 2 - Distribuição dos artigos levantados por ano de publicação 
Conforme se observa no Gráfico 1 e no Gráfico 2 não foram identificados grande número de trabalhos relacionados mais especificamente ao mapeamento e medição do processo do consumidor (valores nas barras mais escuras), por outro lado, foi identificada uma quantidade maior de estudos voltados à aplicação do mapa de processos ou do VSM em serviços.

Antes do ano de 2003 nenhum trabalho associado a categoria de "Trabalhos sobre Mapa de Consumo e Blueprint em serviço" foi identificado nas fontes selecionadas. Assim, até o ano de 2005 em que Womack e Jones publicaram o artigo intitulado "Lean Consumption" este assunto não havia atraído a atenção da comunidade acadêmica. Neste trabalho, os autores propuseram a adoção de uma nova ferramenta, o Mapa de Consumo, para visualização e medição das atividades desempenhadas pelos consumidores e no ano seguinte, na obra "Soluções Enxutas: Como empresas e clientes conseguem juntos criar valor e riqueza" (WOMACK; JONES, 2006) destacaram ainda mais a necessidade de considerar o cliente como agente participativo na execução de processos de serviço. Esta publicação serviu para chamar a atenção para a importância de mapear e medir o esforço do consumidor em processos de serviço.

Embora nos anos de 2007 a 2011 se observe um aumento no número de trabalhos que abordam o mapeamento e medição das atividades dos consumidores, a quantidade de estudos encontrados nesta vertente mais específica ainda mostra-se tímida, comparativamente aos trabalhos que tratam da utilização do mapa de processo em serviços.

Os trabalhos identificados na literatura que revelaram relação com o tema desta pesquisa foram analisados com maior grau de profundidade e serviram de base para a identificação de ferramentas de mapeamento que permitem contemplar o papel participativo do consumidor.

As principais ferramentas que esta literatura tem proposto para construção de mapas que contemplem as atividades dos consumidores em processos de serviço são o Blueprint e o Mapa de Consumo.

Em anos mais recentes, a ferramenta Blueprint passou frequentemente a ser citada por artigos que a consideram como um meio para visualizar o papel do consumidor 
apresentando tal forma de aplicação em casos práticos (KUMAR; STRANDLUND; THOMAS, 2008; KUMAR; HUDSON; LOWRY, 2010; KUMAR; STEINEBACH, 2008) e de forma combinada com outras ferramentas e metodologias de melhoria de processos (CHUANG, 2007; CHANG; YANG, 2010).

Entretanto, não foi identificada nenhuma pesquisa que replicasse a aplicação da ferramenta Mapa de Consumo, proposta por Womack e Jones (2006), em um caso real. Cinco anos após a publicação da obra Soluções Enxutas, a extrapolação desta técnica de mapeamento para casos práticos não foi identificada na revisão da literatura, fato que é intrigante dada a enorme celebridade conquistada por estes autores tanto no campo acadêmico como no empresarial.

Diante dos dados coletados nesta revisão pode-se concluir que há uma carência de estudos no campo acadêmico voltados para o mapeamento e medição das atividades dos consumidores em processos de serviço.

Avanços neste campo do conhecimento são necessários para que haja uma maior disseminação e compreensão de como construir mapas que projetem a participação dos consumidores nos processos.

Diante disto, esta pesquisa pretende tratar esta lacuna, inicialmente, com um levantamento das ferramentas de mapeamento discutidas na literatura que possibilitam a visualização da participação do consumidor em processos de serviço e, posteriormente, por meio da aplicação da ferramenta Mapa de Consumo (WOMACK; JONES, 2006) em casos reais.

\subsection{FERRAMENTAS DE MAPEAMENTO DO CONSUMIDOR}

O principal atributo das ferramentas de mapeamento é o de possibilitar a visualização de um dado processo de forma sequencial. $\mathrm{Na}$ literatura são encontradas diversas ferramentas para mapeamento de processos, cada qual apresentando características diferentes. 
Conforme a particular ferramenta de mapeamento adotada pode-se observar diferentes ângulos de um mesmo processo com maior ou menor grau de profundidade na visualização do fluxo.

Os mapas de processo utilizados para manufatura focam nas atividades internas da organização e nas atividades de seus fornecedores. Como em tais atividades não há influência direta do consumidor nos processos operacionais, não é necessária a identificação e detalhamento do papel do consumidor no processo produtivo.

As técnicas de mapeamento utilizadas na manufatura quando incluem o consumidor, limitam-se a considerá-lo (i) no final do processo como o cliente final ou (ii) no início do processo como demandante, impulsionando o processo produtivo. Para as empresas do setor manufatureiro, mapear as atividades desempenhadas pelos consumidores não se mostra tão essencial para melhoria do processo como nos processos do setor de serviço, no qual o consumidor participa ativamente do processo de serviço e, muitas vezes, atua como co-produtor.

Portanto, para representar processos de consumo de serviço, um mapa deve possibilitar a visualização do consumidor interagindo com o processo produtivo, principalmente quando ele desempenha papel de co-produtor.

Dentre as ferramentas de mapeamento que consideram o consumidor como agente participativo, identificadas na revisão da literatura, destacam-se o SIPOC, Blueprint, Mapa de Consumo, Carta de Atividades e SERVPRO. Estas cinco ferramentas serão detalhadas a seguir.

\subsubsection{SIPOC}

O SIPOC - Suppliers, Inputs, Process, Outputs, Customers - é um mapa de alto nível que possibilita a visualização do processo estudado (RASMUSSON, 2006). É estruturado em cinco colunas onde são indicador da esquerda para direita, os fornecedores envolvidos (Supply), as entradas necessárias (Inputs), o processo em 
análise (Process), as saídas do processo (Outputs) e os clientes atendidos pelo processo (Customers) conforme exemplificado na Figura 7.

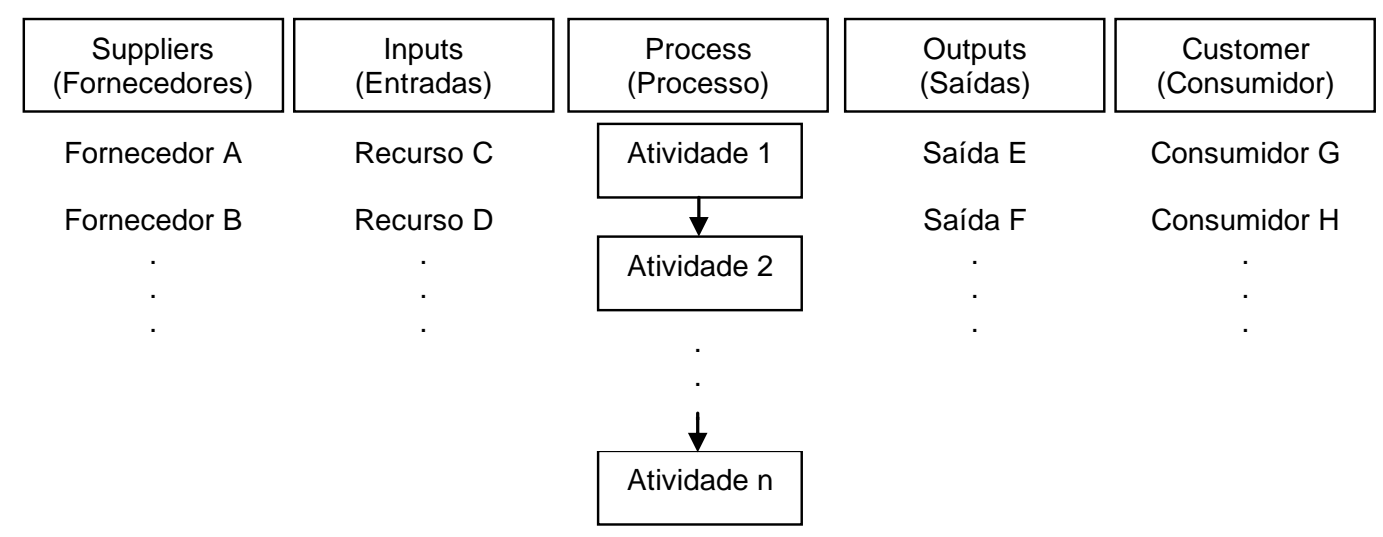

Figura 7 - Estrutura do SIPOC

Fonte: Rasmusson (2006, p. 4)

O SIPOC, traduzido para o português como FEPSC (Fornecedores, Entradas, Processo, Saídas, Consumidores) é amplamente utilizado com a metodologia Seis Sigma para desenho de processos e identificação dos recursos e agentes envolvidos na sua execução.

Esta ferramenta possibilita visualizar os recursos necessários para execução de um dado processo e, especificamente no mapeamento de serviços, possibilita verificar os recursos que o consumidor necessita para executar as atividades que the são atribuídas. Estes recursos podem ser provenientes da empresa prestadora do serviço ou do próprio consumidor.

Os recursos (inputs) provenientes do consumidor referem-se a bens $\mathrm{e}$ conhecimentos que este deve dispor para conseguir executar as atividades do processo e atingir o resultado desejado, representando, consequentemente, custos para o consumidor. Por exemplo, se uma pessoa desejar jogar futebol com seus amigos e alugar uma quadra durante um determinado período de tempo alguns recursos deverão ser providos pelo próprio cliente. Os jogadores deverão levar as roupas adequadas, as chuteiras, a bola, água e os demais itens que considerarem necessários para que a partida aconteça como o time espera. Alguns recursos são imprescindíveis para que o jogo aconteça, mas mesmo assim nem sempre são fornecidos pelo provedor do serviço ou em outras circunstâncias são cobrados como 
custo extra, como quando, ao jogar boliche, se exige o uso de sapatos específicos cobrados separadamente.

Koning, Does e Bisgaard (2008) apresentam uma aplicação prática da ferramenta SIPOC para um processo de serviço de uma seguradora. Através da associação do pensamento lean com a metodologia Seis Sigma os autores propõem um guia para atingir melhorias nos processos de serviço. No exemplo de diagrama SIPOC estruturado por estes autores, ilustrado na Figura 8, verifica-se o papel do cliente como fornecedor de certas entradas e recursos do processo e não somente como consumidor das saídas. É exigido do cliente que elabore um termo escrito, realize uma ligação ou envie uma demanda por e-mail para iniciar o processo de adesão à uma nova apólice de seguro.

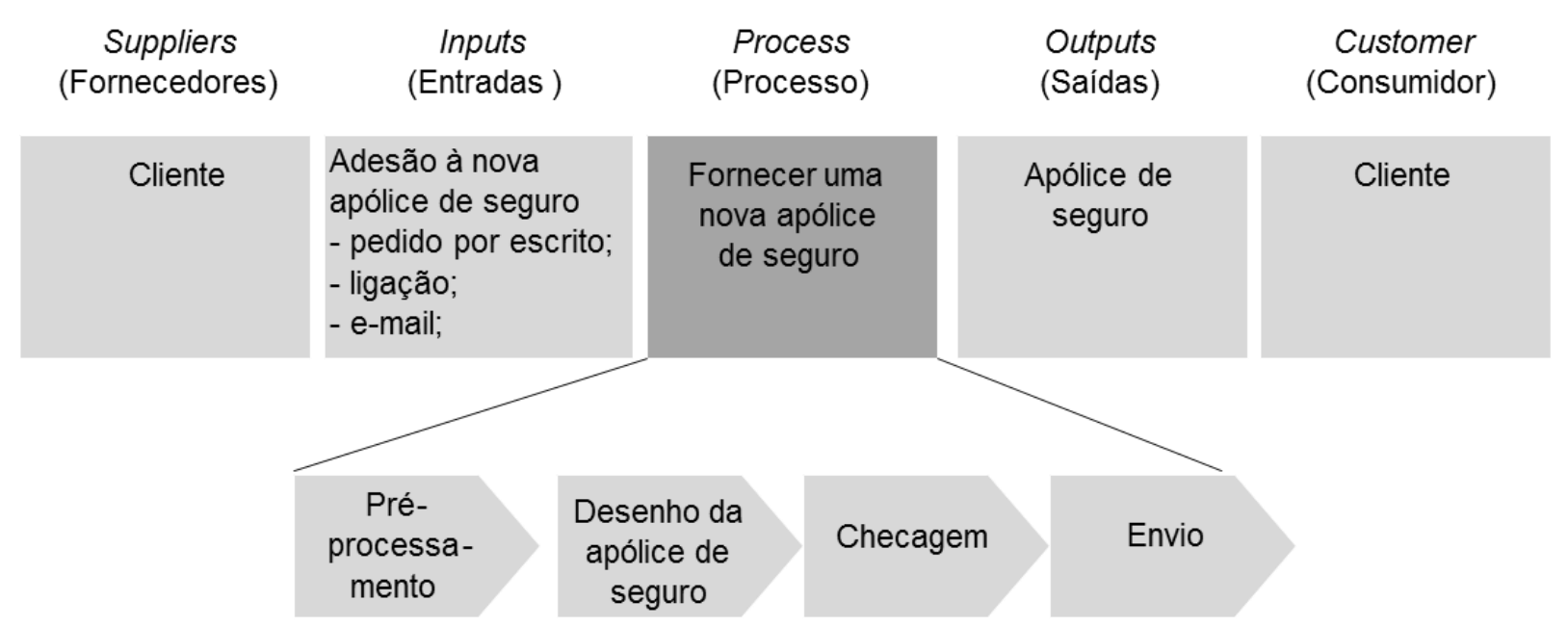

Figura 8 - Descrição do processo para emitir uma nova apólice de seguro

Fonte: Adaptada de Koning, Does e Bisgaard (2008, p. 8)

Esta ferramenta possibilita, portanto, visualizar a participação do consumidor no processo de serviço, fornecendo uma visão de alto nível (macro) do processo, ou seja, sem um alto grau de detalhamento das atividades desempenhadas, mas evidenciando os agentes envolvidos no processo e recursos necessários que influenciam na obtenção do resultado desejado. 


\subsubsection{Blueprint}

Esta ferramenta de mapeamento possibilita a visualização da participação do consumidor ao longo de um processo produtivo e dos pontos de interação do mesmo com a organização provedora do serviço. "O blueprint de serviços é um mapa ou fluxograma de todas as transações integrantes de um processo de prestação do serviço" (FITZSIMMONS; FITZSIMMONS, 2005, p. 95).

Shostack (1987) define o Blueprint como uma técnica de mapeamento que possibilita a visualização do processo de serviço e de seus pontos de divergência ${ }^{3}$ e mostra onde e como ocorrem as relações entre os agentes envolvidos. Conforme observado no exemplo da Figura 9, alguns símbolos específicos são utilizados para denotar características do processo. O leque presente na frente de uma tarefa denota uma gama de opções, possíveis divergências de caminho no processo, onde diferentes ações/escolhas podem ser adotadas. A ausência destes leques num processo denota sua padronização, o que implica que somente uma ação poderá ser seguida após uma tarefa específica.

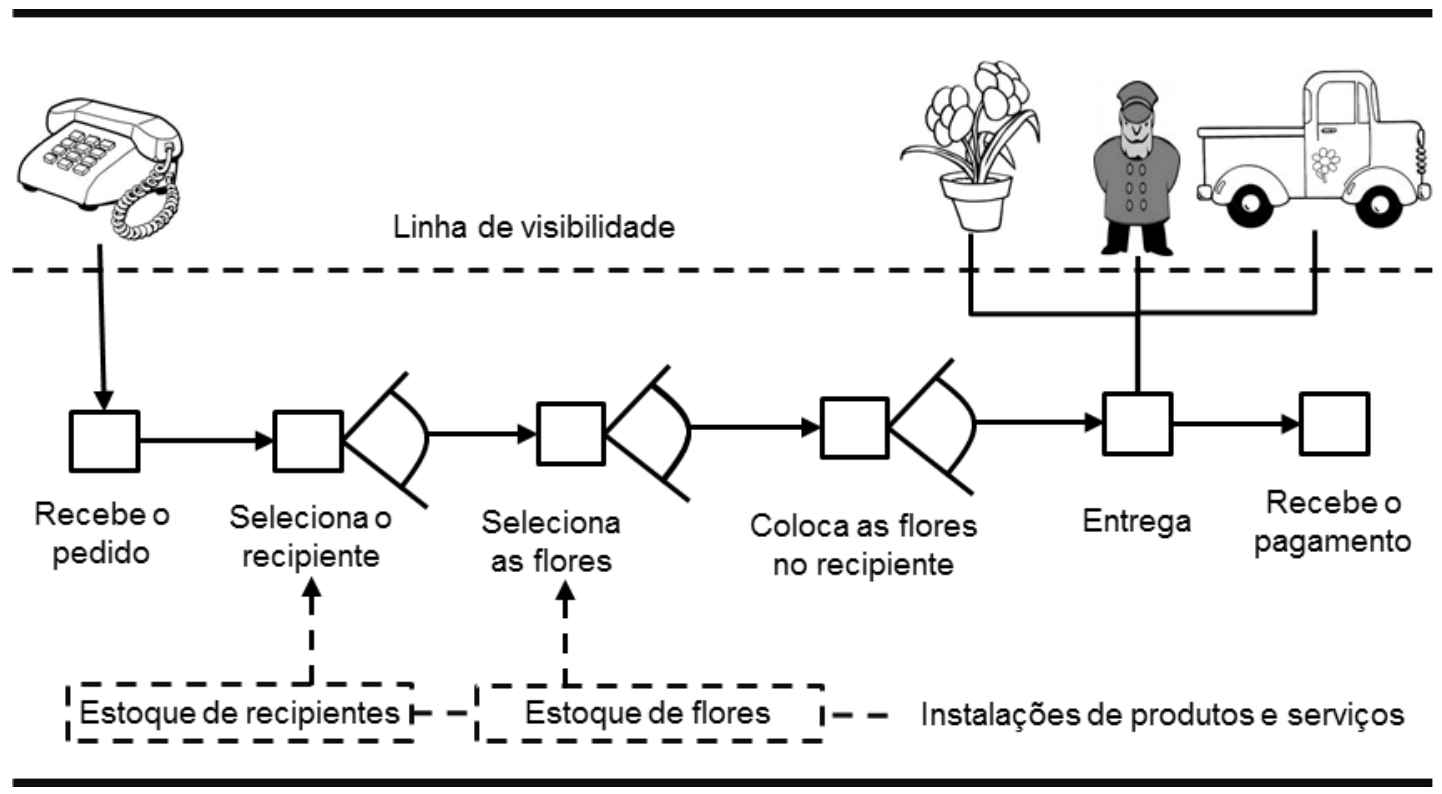

Figura 9 - Blueprint de uma floricultura delivery

Fonte: Adaptada de Shostack (1987, p. 36)

3 O termo "ponto de divergência" é aqui adotado no sentido utilizado por Shostack (1987) que se refere aos pontos onde o fluxo do processo pode se ramificar como points of divergence. 
Esta ferramenta de mapeamento tem sido frequentemente utilizada para verificar os pontos de interação dos consumidores com a organização prestadora do serviço (BITNER; OSTROM; MORGAN, 2008). Trata-se de uma ferramenta que auxilia a visualização do processo atual de serviço e a definição de possíveis melhorias no fluxo de processo das organizações considerando o consumidor.

O papel do consumidor no processo de serviço é considerado fator fundamental na construção do Blueprint, o que diferencia esta ferramenta de outras técnicas de mapeamento. O principal aspecto inovador desta ferramenta de mapeamento é a adoção da chamada "linha de visibilidade" que separa as tarefas da organização que podem ser observadas pelo consumidor e que ocorrem na linha de frente (Front Office), das tarefas que não são percebidas pelo consumidor e que ocorrem na retaguarda (Back Office).

Fliess e Becker (2006) descrevem que a ferramenta Blueprint apresenta no seu eixo horizontal as tarefas em sequência cronológica executadas pelos consumidores ou pela organização, enquanto na direção vertical são distinguidas as diferentes áreas de ação separadas por linhas.

Bitner apud Fitzsimmons e Fitzsimmons (2005) ilustra a construção de um Blueprint através do exemplo da Figura 10, referente a processos típicos encontrados em um hotel de luxo.

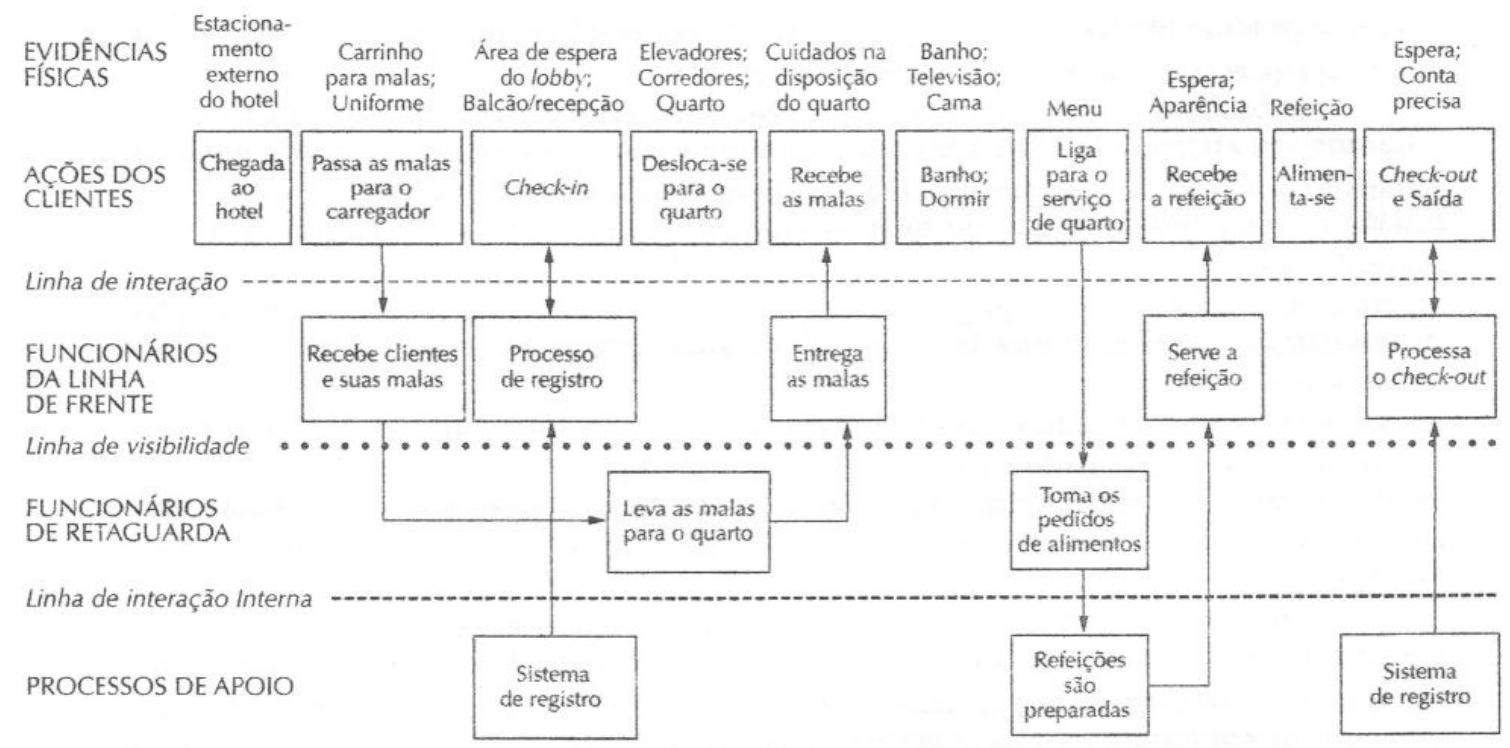

Figura 10 - Blueprint para um hotel de luxo

Fonte: Bitner apud Fitzsimmons e Fitzsimmons (2005, p. 96) 
A Figura 10 evidencia como esta ferramenta de mapeamento detalha as tarefas desempenhadas pelos consumidores, mostrando de forma clara as interações do cliente com a empresa provedora do serviço e as tarefas que podem ser observadas pelo consumidor, alocadas acima da linha de visibilidade.

Como se pode observar na Figura 10, o Blueprint de serviços apresenta geralmente cinco componentes que guiam a construção do mapa, sendo posicionados em faixas horizontais, as quais são descritas a seguir:

a. Ações do consumidor: nelas são inseridas as tarefas desempenhadas pelo consumidor para execução e entrega do processo de serviço. Mostram o grau de envolvimento e co-participação do consumidor para se atingir o resultado do serviço, podendo referir-se a uma simples escolha do serviço até a execução de tarefas operacionais mais demandantes para a concretização do mesmo.

b. Ações da linha de frente (Front Office; onstage): estas incluem as ações executadas pela organização provedora do serviço que ocorrem na linha de frente, "no palco", e que, portanto, são percebidas pelo consumidor. Durante a execução destas tarefas pode ou não ocorrer interação direta entre empresa e consumidor, mas ocorrendo ou não uma interação face-a-face do consumidor com um funcionário da empresa, as tarefas executadas na linha de frente são visíveis e perceptíveis pelo consumidor e podem, portanto, influenciar seu julgamento em relação ao serviço prestado.

As ações da linha de frente são separadas das ações do consumidor pela "linha de interação". Sempre que a linha de interação é cruzada (visualmente representada por uma linha vertical trespassando a linha de interação posicionada horizontalmente), isso representa que o consumidor e o provedor (através dos seus funcionários da linha de frente) têm um ponto de contato direto, ocorrendo o denominado "encontro de serviço" (FITZSIMMONS; FITZSIMMONS, 2005) ou "momento da verdade" (BITNER; OSTROM; MORGAN, 2008), ou "hora da verdade" (ALBRECHT, 1992) ou, ainda, "experimentação do serviço" (VOSS; ZOMERDIJK, 2007). 
c. Ações da retaguarda (Back Office; backstage): referem-se às ações desempenhadas pela organização provedora do serviço, porém, diferentemente do que ocorre na linha de frente, não são vistas pelo consumidor, pois ocorrem "fora do palco". A retaguarda executa as tarefas necessárias para concretização do serviço demandado pelo consumidor, mas não interage diretamente com ele $e$, portanto, muitas vezes são imperceptíveis aos olhos do cliente.

Tanto as tarefas da retaguarda como as da linha de frente são executadas pela empresa provedora do serviço, mas são segmentadas pela linha de visibilidade. As tarefas posicionadas acima da linha de visibilidade (executadas pela linha de frente) estão expostas aos consumidores, enquanto as tarefas que se encontram abaixo desta linha (executadas pela retaguarda) não são vistas pelo consumidor. Isto significa que as atitudes e a forma de interação dos funcionários da linha de frente tendem a exercer maior influência sobre a percepção do consumidor.

d. Processos de apoio: referem-se aos processos de apoio que precisam ocorrer para que a empresa funcione adequadamente e o serviço seja fornecido. Representam áreas ou sistemas de suporte ao processo mapeado e são alocados no Blueprint abaixo da "linha de interação interna". As conexões entre as ações da retaguarda e os processos de apoio (representadas pelas linhas verticais) mostram as interações interfuncionais, dentro da organização provedora, necessárias para concretização do serviço.

e. Evidências físicas: são os fatores ou aspectos observáveis que fazem parte da experiência do serviço percebido pelo consumidor. Em cada interação entre o provedor e o consumidor, ou "encontro de serviço", são gerados resultados percebidos pelo cliente sobre o serviço que influenciam o resultado final do processo de serviço.

Em um outro exemplo de aplicação do Blueprint, ilustrado na Figura 11, Kumar, Strandlund e Thomas (2008) utilizam esta ferramenta para mapear um processo de reparo de um produto na garantia. Neste exemplo, se observa a aplicação da 
ferramenta para construção do mapa de um processo de serviço decorrente da aquisição de um produto.

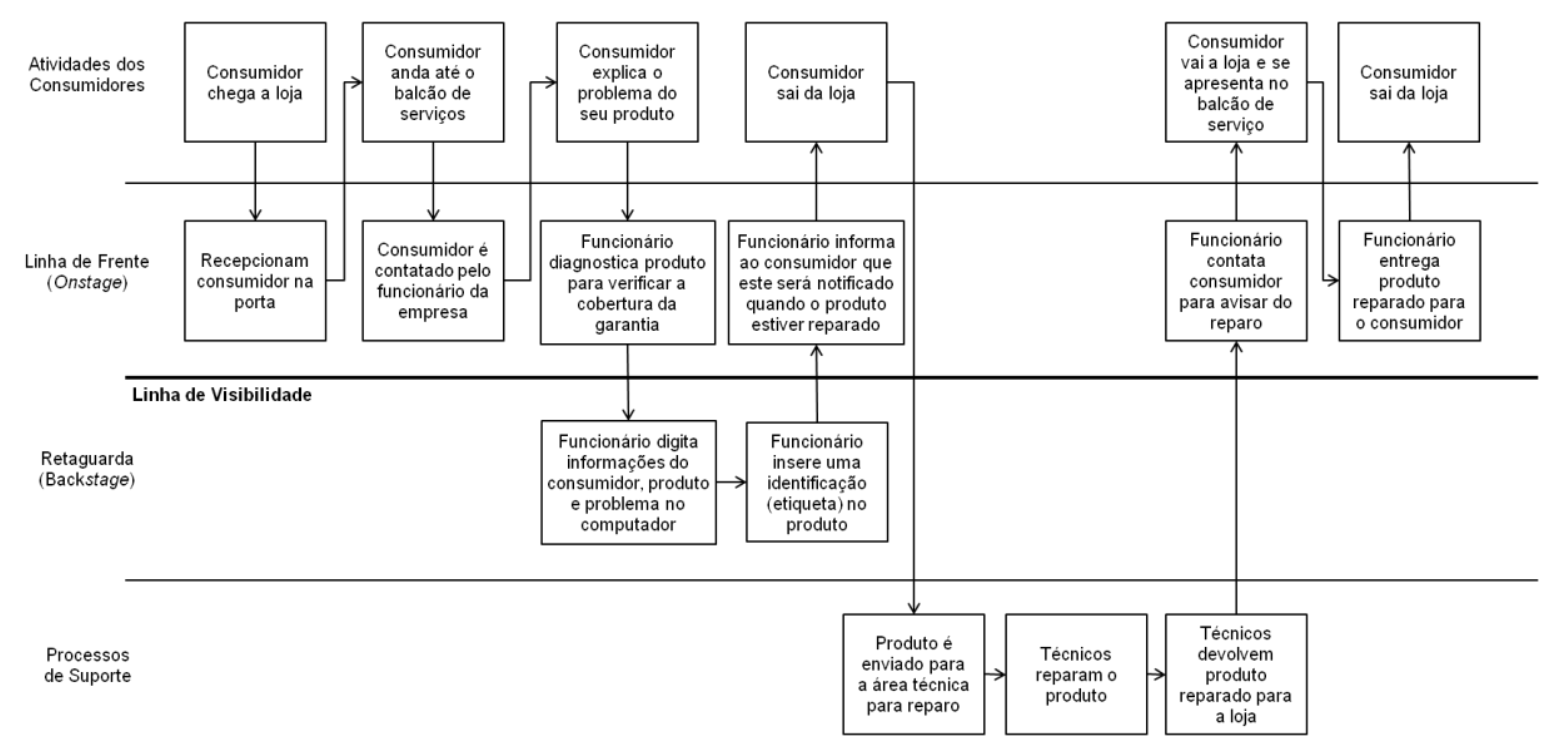

Figura 11 - Blueprint do processo de reparo de um produto na garantia

Fonte: Kumar; Strandlund e Thomas (2008, p. 987)

O Blueprint mostra-se como uma ferramenta que facilita a visualização das ações, executadas pelo consumidor e as ações executadas pela empresa, segmentando as do segundo tipo e, ações de linha de frente e de retaguarda. Adicionalmente, esta ferramenta serve para identificar os pontos de interação entre consumidor e empresa evidenciando as tarefas que tendem a exercer maior influência sobre a percepção do consumidor a respeito do serviço.

\subsubsection{Mapa de Consumo}

O Mapa de Consumo foi concebido por Womack e Jones (2006) com o objetivo de promover a verificação das tarefas executadas no gemba do consumidor. Esta forma de mapa deriva do mapeamento do fluxo de valor (VSM - Value Stream Mapping) amplamente utilizado para levantamento do estado atual de um processo e proposição de um estado futuro melhorado em iniciativas de implementação da metodologia lean nas empresas. 
A aplicação desta ferramenta de mapeamento é um meio de visualização e medição das tarefas executadas pelos consumidores, a fim de analisar possíveis melhorias no seu fluxo para aumento da qualidade do serviço e redução do esforço requerido do consumidor.

Womack e Jones (2006) propuseram a utilização desta ferramenta enfatizando a importância de observar e mapear o processo de serviços de uma forma mais abrangente, ilustrando o fluxo das tarefas da empresa num mapa denominado "Mapa de Provisão" (provision map) e ilustrando o fluxo de tarefas do consumidor num mapa denominado "Mapa de Consumo" (consumption map). A visualização do processo de serviços sob diferentes pontos de vista possibilita reconhecer oportunidades de melhorias no fluxo de forma a agregar maior valor ao consumidor além de trazer maior eficiência para as empresas.

Conforme se verifica na Figura 12, o Mapa de Consumo é composto das tarefas executadas pelo consumidor durante um processo de serviço enquanto o Mapa de Provisão apresenta as tarefas desempenhadas pela empresa provedora do serviço como ilustra a Figura 13. O exemplo considerado por Womack e Jones (2006) nas Figuras 12 e 13 refere-se a um serviço de conserto de automóvel. 


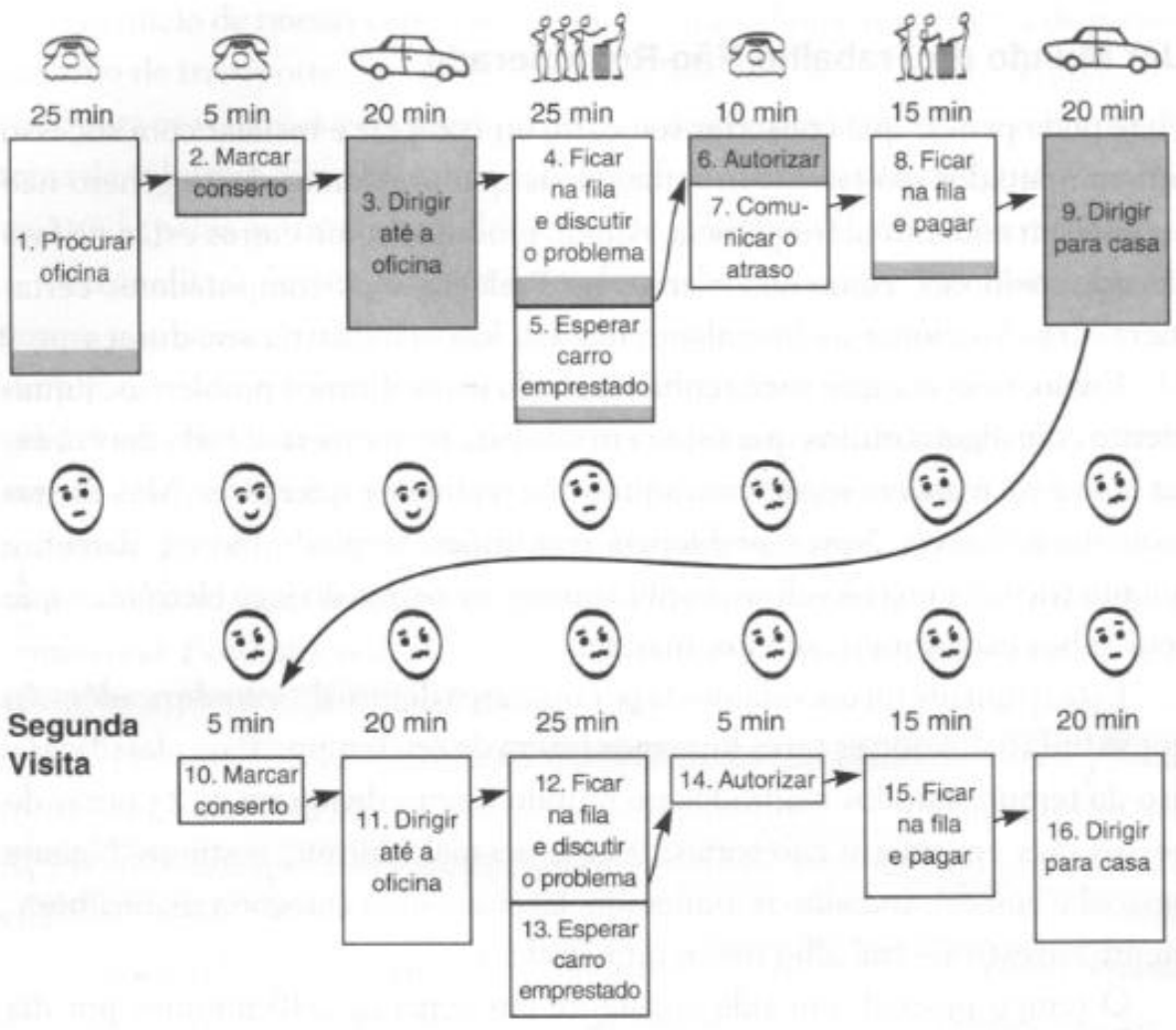

Contagem

Tempo do consumidor: $210 \mathrm{~min}$

Tempo que cria valor: $58 \mathrm{~min}$

Valor/total: $\quad 28 \%$

Valor $=\square$ Desperdicio $=$

Figura 12 - Mapa de Consumo de um processo de reparo de automóvel Fonte: Womack e Jones (2006, p. 20) 


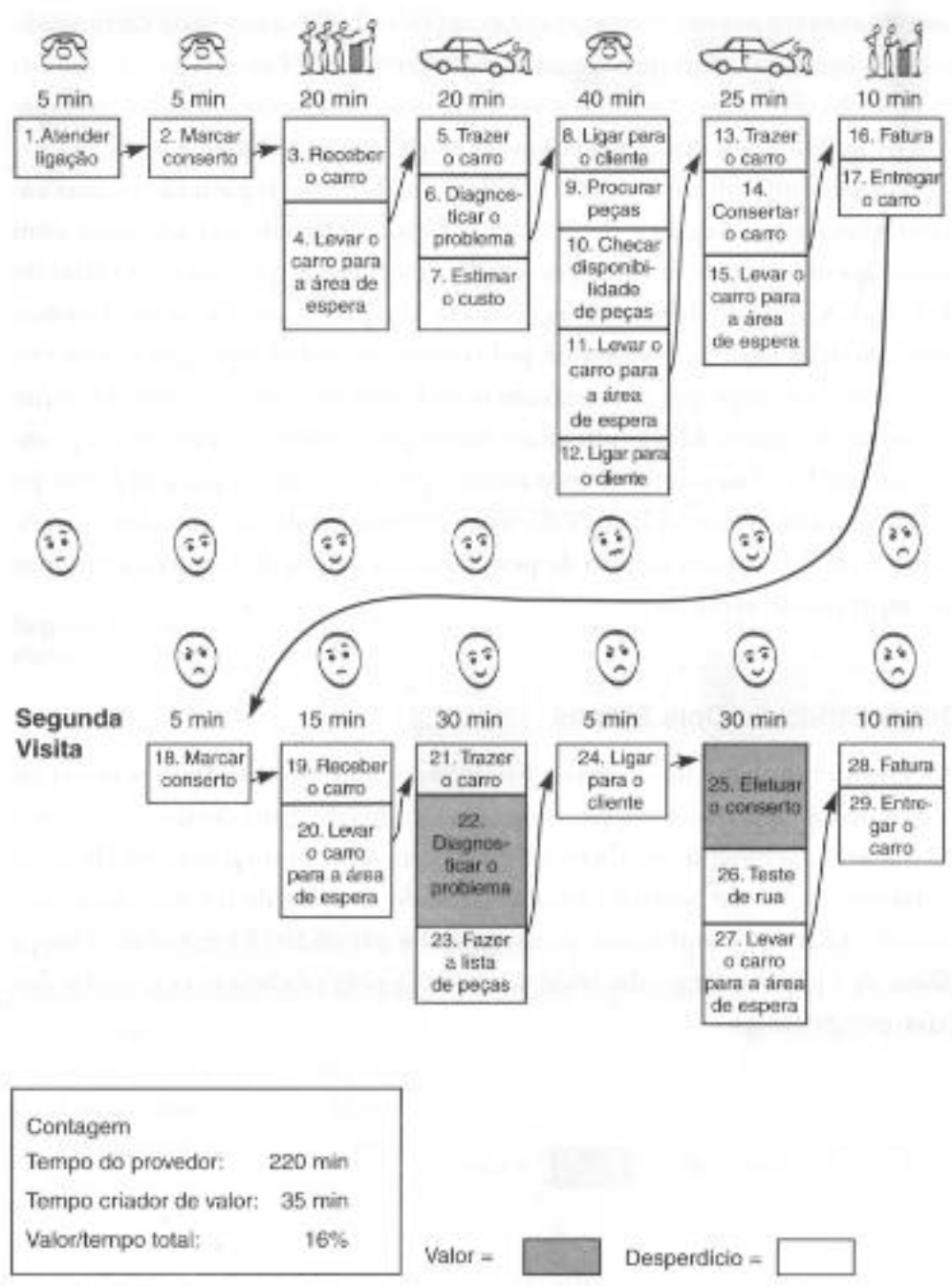

Figura 13 - Mapa do Provedor de um processo de reparo de automóvel Fonte: Womack e Jones (2006, p. 30)

Nestes mapas, as tarefas realizadas são representadas por blocos cuja área representa o tempo que demandam. Este tempo pode ser consumido de forma eficaz ou não, dado o objetivo do processo de serviço considerado.

Nas Figuras 12 e 13, a parcela do bloco destacada em cinza, representa o tempo gasto pelo consumidor em tarefas que considera importantes para a concretização do serviço, enquanto a parcela em branco representa o tempo gasto com tarefas ineficazes que poderiam ser reduzidas ou eliminadas ${ }^{4}$. Portanto, as partes do fluxo

4 Na manufatura é usual considerar três situações para representar a criação de valor e ocorrência de desperdício num fluxo de valor. Consideram-se as categorias: agrega valor para o cliente (value), desperdício (waste, muda) e desperdício, mas necessário (non-value but necessary). Esta terceira situação é considerada para classificar atividades que são essenciais para a organização, mas que não agregam valor diretamente para o cliente, como atividades atreladas à auditoria, atendimento às normas de órgãos regulamentadores (Jin et al., 2008). 
em cinza indicam que contribuem para criar valor, enquanto as partes em branco evidenciam a ocorrência de desperdícios. No exemplo considerado, o fato do problema do consumidor não ter sido resolvido na primeira visita faz com que a segunda visita para conserto do carro seja um retrabalho. Assim, na visão do cliente muito tempo foi desperdiçado nas tarefas da primeira visita e caso tivessem sido bem executadas, a segunda visita não teria sido necessária.

Nos fluxos exemplificados na Figura 12 e na Figura 13 os autores desmembram um processo simples em tarefas cuja execução pelo consumidor não exige grande treinamento ou orientação, mas que somadas acarretam em esforço e dedicação de tempo consideráveis que deveriam ser reduzidos. A gravidade da situação torna-se ainda mais evidente ao se considerar a proporção do tempo que agrega valor para o consumidor - denominado tempo criador de valor - em relação ao tempo total gasto com o processo.

Para desenhar um Mapa de Consumo os seguintes passos devem ser seguidos:

a. Listar todas as tarefas realizadas pelo consumidor e relacioná-las através de um fluxo onde cada bloco (retângulo) representa uma tarefa desempenhada;

b. Inserir os tempos para execução de cada tarefa;

c. Segregar em cada tarefa a parcela que agrega e a que não agrega valor para o consumidor;

d. Inserir o grau de incômodo do consumidor para executar cada tarefa.

Para demonstrar o grau de satisfação ou incômodo das pessoas que executam as tarefas no processo pode se recorrer ao uso das imagens da Figura 14. No Mapa de Consumo estas figuras retratam a satisfação ou incômodo do consumidor em relação às tarefas sob sua responsabilidade, enquanto no Mapa de Provisão retratam a percepção dos funcionários da empresa provedora do serviço. 

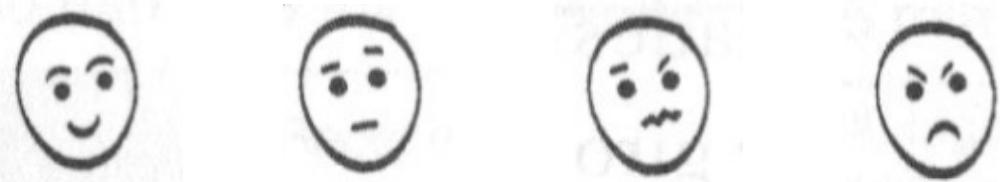

Figura 14 - Escala visual utilizada para retratar a satisfação ou incômodo das pessoas envolvidas no processo em relação às tarefas executadas

Fonte: Adaptada de Womack e Jones (2006, p. 20 e 30)

Por fim, ainda são utilizadas figuras de objetos como carro, telefone e fila de pessoas para detalhar a forma de interação entre consumidor e empresa.

Womack e Jones (2006) propõem, ainda, a construção de um mapa combinado de consumo e provisão a fim de descrever um fluxo de valor completo que permita observar as tarefas executadas pelo consumidor paralelamente às tarefas desempenhadas pela empresa, conforme se verifica na Figura 15.

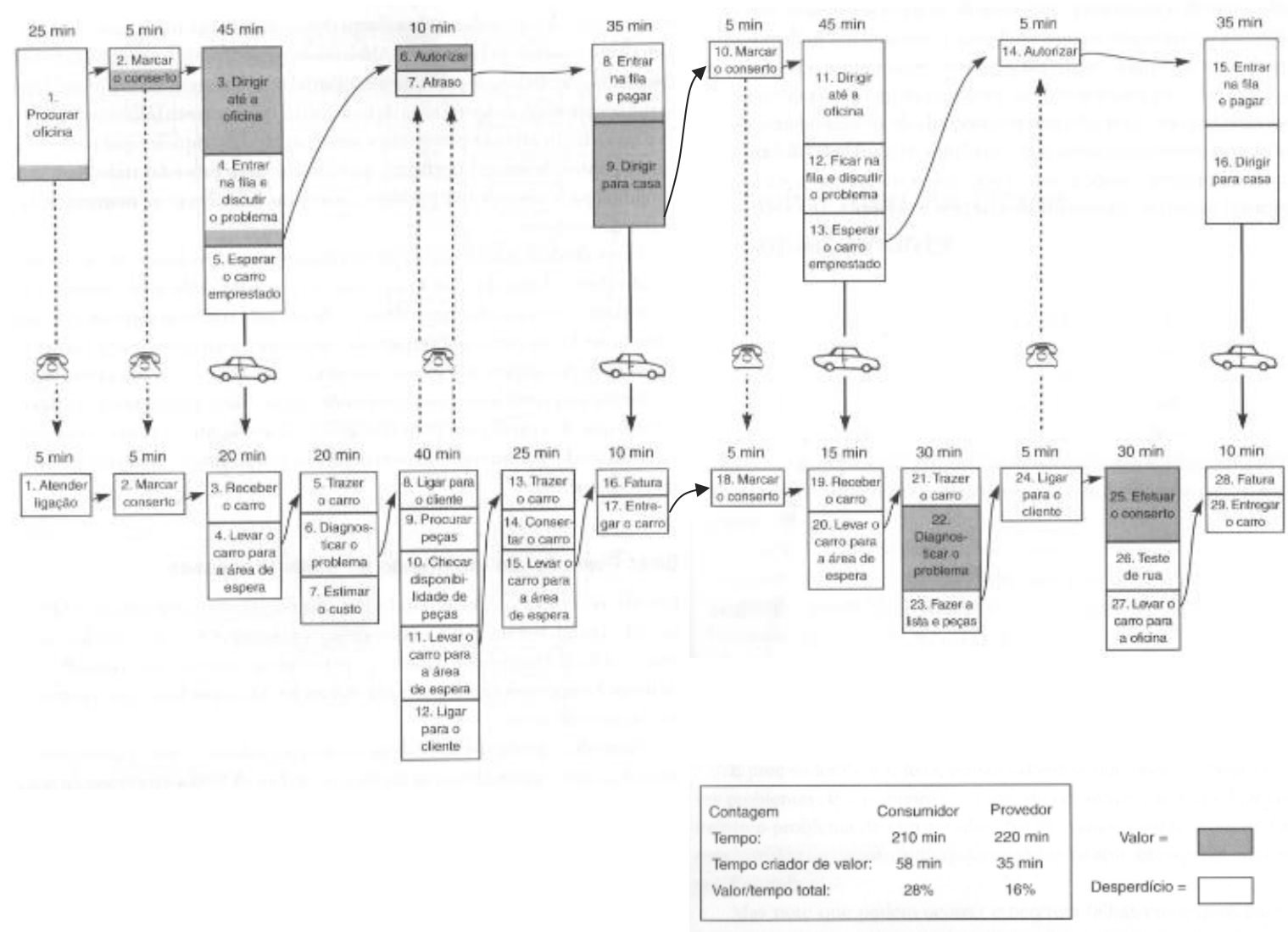

Figura 15 - Fluxo de valor completo combinando Mapa de Consumo e Mapa de Provisão Fonte: Womack e Jones (2006, p. 32 e 33) 
A ferramenta Mapa de Consumo além de possibilitar a visualização do processo tem a função de evidenciar o esforço e satisfação do consumidor em relação a cada tarefa. Para a medição da participação do consumidor num processo de serviço as seguintes variáveis podem ser utilizadas:

a. Quantidade de etapas: quanto maior o volume de tarefas atribuídas ao consumidor maior o esforço e conhecimento necessários para executar o processo.

b. Tempo dedicado: quantidade de tempo necessário para a execução de uma tarefa. O tempo de cada tarefa ainda pode ser avaliado em termos de agregação de valor. Quanto maior o tempo do consumidor dedicado à realização de uma tarefa, menor tende a ser o valor percebido em relação a ela, e maior tende a ser o incômodo causado ao consumidor durante a execução da tarefa.

c. Grau de incômodo ou satisfação: percepção do consumidor em relação à tarefa. Pode estar atrelado à percepção de fatores como facilidade de se executar o processo, disponibilidade do fornecedor, tempo dedicado e resultado em termos de agregação de valor.

O Mapa de Consumo busca fornecer um panorama completo em relação à participação do consumidor no processo, elencando as tarefas desempenhadas pelo consumidor, relacionando-as ao tempo dedicado e grau de satisfação do consumidor. Por meio do Mapa de Consumo, Womack e Jones (2006) procuram estender a aplicação dos conceitos da filosofia lean para a avaliação das tarefas desempenhadas pelos consumidores. Os autores propõem que os tempos despendidos pelos consumidores sejam analisados de forma crítica e que se busque uma clara distinção dos momentos em que o consumidor teve prazer em participar do processo daqueles em que isso não ocorreu de forma a melhorar a prestação do serviço.

As tarefas atribuídas aos consumidores nem sempre são complexas, mas exigem deles tempo e recursos que poderiam ser melhor utilizados em tarefas que thes dessem prazer. "Mesmo tarefas simples de consumo envolvem muitas etapas e 
muito tempo do consumidor. E a maior parte deste tempo é desperdiçada" (WOMACK; JONES, 2006, p. 15).

\subsubsection{Carta de Atividades}

As Cartas de Atividades são utilizadas para identificar a relação entre as pessoas e máquinas envolvidas em um processo produtivo (CORRÊA; CORRÊA, 2004). Amplamente utilizadas em estudos de tempos e métodos para planejamento e controle de processos de manufatura, esta ferramenta fornece uma visão detalhada das atividades de um processo e permite uma análise da forma de uso dos recursos alocados como operadores e máquinas.

Inicialmente foram adotadas nas indústrias, onde são mais conhecidas pela denominação Diagrama Homem-Máquina, como uma ferramenta para descrever e analisar a interação entre operador e máquina de forma a identificar tempos ociosos e ocupá-los de forma mais eficiente (BARNES, 1977).

Expandindo sua aplicação para a área de serviços, a Carta de Atividades pode auxiliar na análise das atividades que compõem os processos de serviço envolvendo diversas combinações de agentes ou recursos como: operador e cliente, operador e máquina, cliente e máquina ou ainda, operador, cliente e máquina.

Cada recurso envolvido no processo é posicionado em uma coluna da Carta de Atividades. Ao longo de cada coluna, as atividades do processo alocadas ao recurso correspondente são enumeradas em ordem cronológica de cima para baixo. Usualmente, adota-se uma escala de tempo que possibilita visualizar o tempo gasto pelos recursos em cada atividade. Quando um recurso não está envolvido na execução de determinada atividade indica-se a ociosidade do mesmo, ou seja, que está em espera. A Figura 16 exemplifica a aplicação da Carta de Atividades para um processo de atendimento de cliente junto ao balcão de um restaurante fast food. 


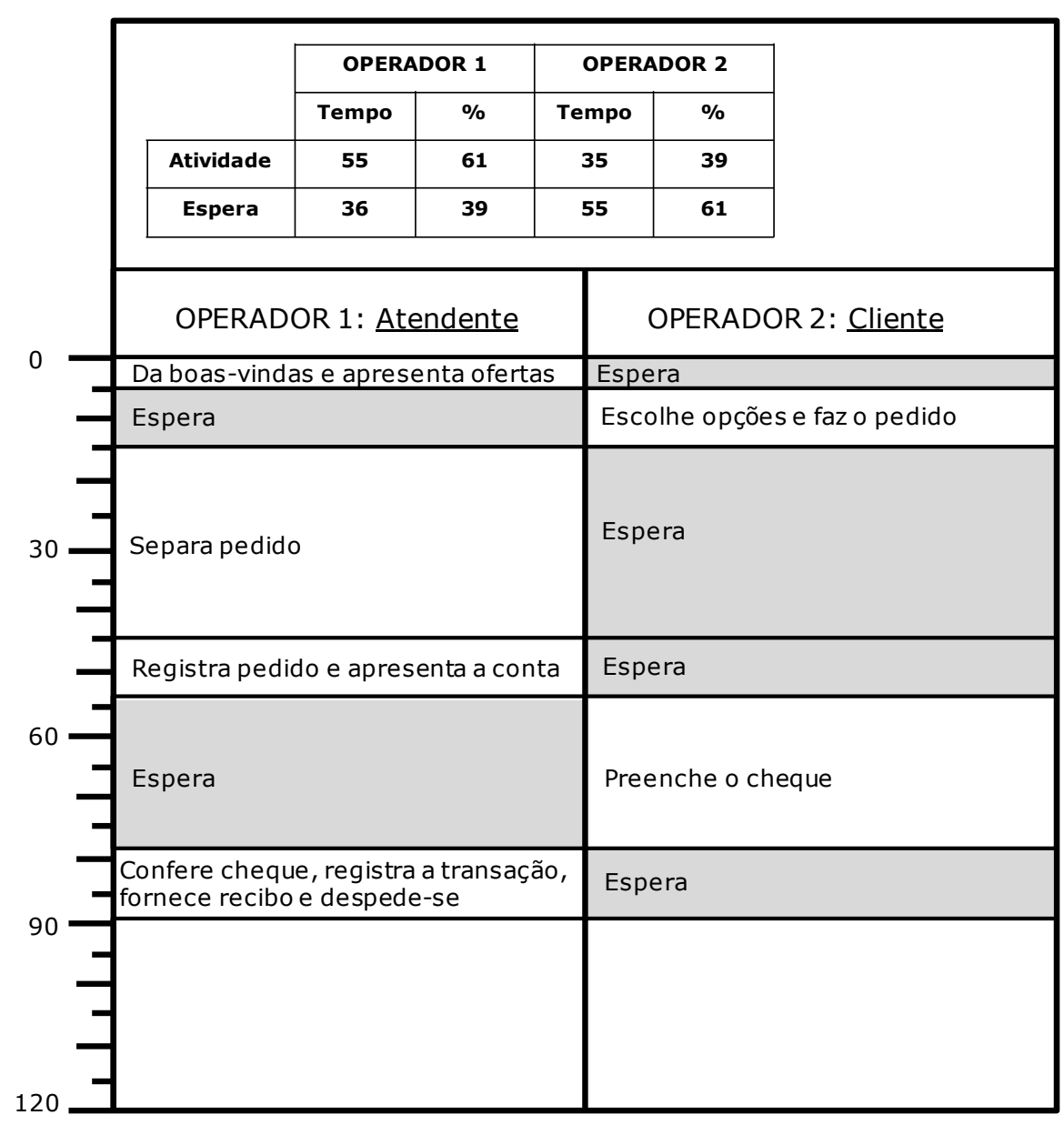

Figura 16 - Exemplo de Carta de Atividades

Fonte: Corrêa e Corrêa (2004, p. 261)

Esta ferramenta é, portanto, aplicável na identificação e medição das atividades executadas pelos consumidores podendo ser utilizada para indicar o tempo gasto por um consumidor no processo de serviço e evidenciar os momentos em que ele fica esperando a execução de uma atividade a ser realizada por um funcionário (operador) ou máquina (sistema) da empresa.

A Carta de Atividade identifica as atividades atribuídas a cada um dos agentes/recursos envolvidos na execução das etapas de um processo e permite uma análise crítica da forma como seus tempos foram gastos. Ao destrinchar o processo em microatividades torna possível, ainda, verificar como a atuação de um recurso influencia e incita a atuação de outro recurso e assim vai encadeando uma sucessão de microatividades. 


\subsubsection{SERVPRO}

A ferramenta de mapeamento e diagnóstico de processo SERVPRO baseia-se no IDEF3 - técnica desenvolvida pela Força Aérea dos Estados Unidos para descrever, especificar e modelar sistemas de manufatura - porém, tendo como foco as atividades desempenhadas pelo consumidor ao longo dos processos de serviço (SANTOS; VARVAKIS, 2002).

O SERVPRO busca avançar na proposta de Tseng et al. (1999) de adaptação do IDEF3 para operações de serviço fazendo com que a ferramenta atenda cinco requisitos: (i) sirva tanto para projeto quanto para análise de processo; (ii) descreva as atividades do ponto de vista do consumidor; (iii) represente o processo de forma gráfica; (iv) assegure facilidade de uso; (v) suporte a avaliação do desempenho de processos (SANTOS; FACHIN; VARVAKIS, 2003).

Esta ferramenta é composta por um diagrama e um documento de elaboração. O diagrama apresenta o fluxo de atividades executadas pelo consumidor de forma gráfica e sequencial utilizando as junções \& ("e"), quando as atividades indicadas ocorrem paralelamente, $\mathrm{O}$ ("e/ou") quando ocorre somente uma atividade ou mais de uma atividade podem ocorrer paralelamente e X ("ou") quando somente uma das atividades consideradas ocorre e o elemento "Go-to" que direciona o fluxo para uma atividade já descrita anteriormente. Na Figura 17 observa-se um exemplo de diagrama SERVPRO para o processo do consumidor em um restaurante selfservice. 


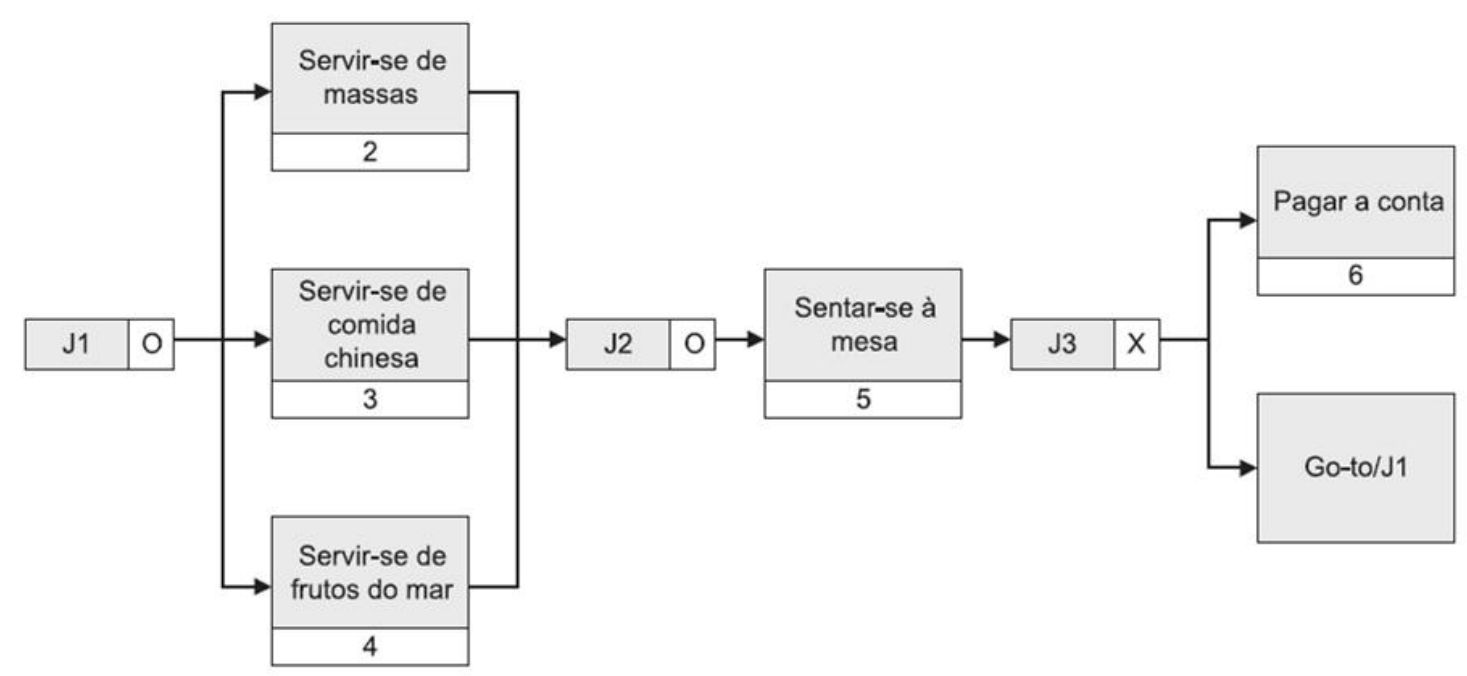

Figura 17 - Diagrama SERVPRO para o processo do consumidor de um restaurante self-service Fonte: Santos e Varvakis (2002, p. 41)

O documento de elaboração serve para detalhar as atividades apresentadas no diagrama e pode ser aplicado às atividades que merecem uma análise mais específica. Neste documento são inseridos os recursos identificados na atividade que entram em contato com o consumidor e que, portanto, podem influenciar sua percepção do serviço. Adicionalmente, são apontadas as interações entre cliente e sistema de serviço utilizando os ícones indicados na Figura 18 para caracterizar as ações ou reações executadas pelo cliente e pelo sistema.

$$
\begin{aligned}
& \rightarrow \text { Ação do cliente. } \\
& \leftarrow \text { Reação do cliente. } \\
& \text { 囟 } \rightarrow \text { Ação do sistema de serviços. } \\
& \leftarrow \text { 亚 Reação do sistema de serviços. }
\end{aligned}
$$

Figura 18 - Ícones para indicar a interação entre cliente e sistema Fonte: Santos e Varvakis (2002, p. 42)

Por fim, são inseridos parâmetros denominados "determinantes da qualidade" que descrevem, a qualidade do serviço segundo critérios do cliente e medidas de desempenho que tangibilizem cada um dos determinantes especificados. Um exemplo do documento de elaboração SERVPRO para a atividade de "pagar a conta" de um restaurante pode ser visualizado na Figura 19. 


\begin{tabular}{|c|c|}
\hline $\begin{array}{l}\text { Atividade de interação } \mathrm{N}^{2}: 6 \\
\text { Nome: Pagar a conta } \\
\text { Rótulo: Pagar a conta }\end{array}$ & $\begin{array}{l}\text { Elemento(s) de contato: } \\
\text { - Garçom } \\
\text { - Conta } \\
\text { - Nota fiscal }\end{array}$ \\
\hline \multicolumn{2}{|c|}{ 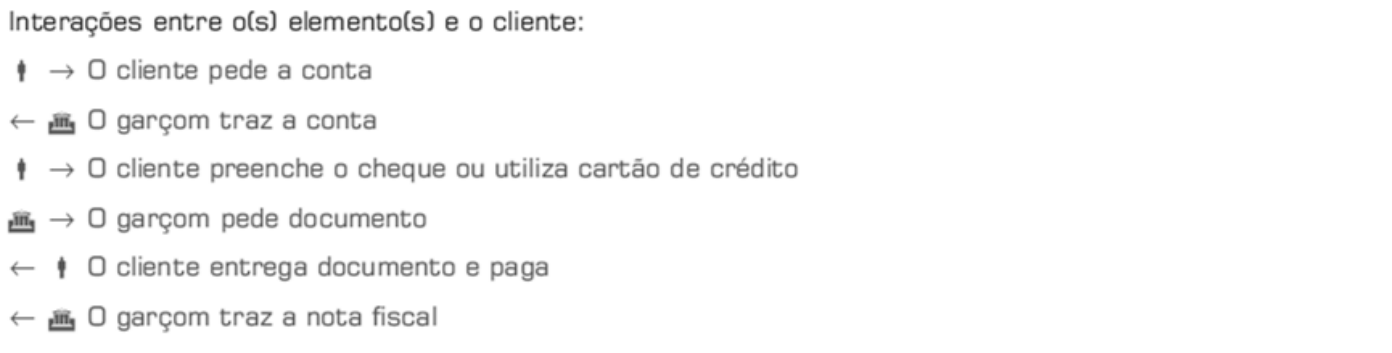 } \\
\hline $\begin{array}{l}\text { Operações do(s) elemento(s): } \\
\text { - Garçom: trazer a conta } \\
\text { - Garçom: receber pagamento e entregar a nota }\end{array}$ & $\begin{array}{l}\text { Operaçōes do cliente: } \\
\text { - Preencher o cheque }\end{array}$ \\
\hline Determinantes da qualidade: & Medidas de desempenho: \\
\hline Confiabilidade & $\begin{array}{l}\text { - \% de contas calculadas com erro } \\
\text { - \% de reclamaçōes relativas à conta }\end{array}$ \\
\hline Rapidez & - tempo médio na entrega a conta \\
\hline Empatia & $\begin{array}{l}\text { - \% de usuários que classificam o tratamento } \\
\text { recebido como "excelente" (escala de } 5 \text { pontos) }\end{array}$ \\
\hline
\end{tabular}

Figura 19 - Documento de elaboração SERVPRO para o processo de pagar a conta de um restaurante

Fonte: Santos e Varvakis (2002, p. 43)

Esta ferramenta para planejamento e análise de processos de serviço representa uma das formas de mapeamento de processos que considera as atividades executadas pelos consumidores. Ademais, atrela a cada atividade do consumidor medidas de desempenho que suportam a definição e medição da qualidade do serviço.

\subsubsection{Comparação entre as Ferramentas de Mapeamento do Consumidor}

A descrição das ferramentas apresentadas nas seções anteriores sugere que existem diferentes formas de construção de um mapa de processo que evidenciem a participação do consumidor no processo de serviço.

Cada ferramenta apresenta características e representações gráficas próprias, de forma que diferentes visões de um mesmo processo podem ser construídas, cada 
qual priorizando determinados aspectos do processo. A Tabela 3 apresenta 0 diferencial das ferramentas SIPOC, Blueprint, Mapa de Consumo, Carta de Atividades e SERVPRO, na forma de visualização da participação do consumidor num processo de serviço destacando os aspectos mais específicos que cada ferramenta exibe.

Tabela 3 - Diferencial das ferramentas de mapeamento em relação à forma de visualização do papel do consumidor em um processo de serviço

\section{Ferramenta Diferencial da ferramenta}

$\begin{array}{ll}\text { SIPOC } & \text { Visualização dos recursos (inputs) despendidos pelo consumidor para } \\ & \text { execução das atividades sob sua responsabilidade }\end{array}$

Blueprint

Visualização da interação entre as partes envolvidas no processo: ações do consumidor, ações da linha de frente, ações da retaguarda, suporte

\begin{tabular}{ll}
\hline Mapa de Consumo & $\begin{array}{l}\text { Medição do tempo das tarefas desempenhadas pelo consumidor } \\
\text { segregando as partes que contribuem e as partes que não contribuem para } \\
\text { agregar valor e destacando, também, o grau de satisfação do consumidor } \\
\text { com a tarefa }\end{array}$ \\
\hline Carta de Atividades & $\begin{array}{l}\text { Visualização do tempo gasto pelo consumidor para execução das } \\
\text { atividades e do tempo em que este permanece em espera }\end{array}$ \\
\hline SERVPRO & $\begin{array}{l}\text { Explicita qual o agente, cliente ou empresa, realiza a ação ou a reação } \\
\text { numa interação e define parâmetros e medidas de desempenho para } \\
\text { determinar a qualidade do serviço }\end{array}$ \\
\hline
\end{tabular}

$\mathrm{Na}$ Tabela 4 tem-se uma comparação das ferramentas de mapeamento pesquisadas em relação a aspectos chave atrelados à forma de visualização e medição da participação do consumidor no processo de serviço. Os aspectos considerados são:

- Grau de detalhamento do fluxo de atividades do consumidor: avalia o grau de detalhamento adotado na construção do mapa para descrição das tarefas desempenhadas pelo consumidor; 
- Grau de detalhamento dos caminhos alternativos do processo: avalia se a ferramenta indica os caminhos alternativos do processo evidenciando quais tarefas são sequenciais e quais são paralelas;

- Caracterização do contato do consumidor com a empresa: descreve como o contato entre consumidor e empresa (linha de frente) é retratado pela ferramenta de mapeamento;

- Grau de detalhamento do contato do consumidor com a empresa: avalia o grau de detalhamento adotado na descrição do contato entre consumidor e empresa;

- Medição do tempo dedicado pelo consumidor: avalia se a ferramenta evidencia o tempo gasto pelo consumidor para executar as tarefas sob sua atribuição;

- Medição do tempo gasto pelo consumidor com desperdícios: avalia se a ferramenta evidencia o tempo de espera do consumidor enquanto o funcionário da empresa ou o sistema executa suas tarefas;

- Medição da satisfação do consumidor com o processo: avalia se a ferramenta evidencia a satisfação do consumidor ao executar as tarefas que lhe cabem;

- Recursos necessários ao consumidor: avalia os recursos necessários para que o consumidor execute as tarefas que lhe cabem; 
Tabela 4 - Comparação entre as ferramentas de mapeamento do consumidor

\begin{tabular}{|c|c|c|c|c|c|}
\hline $\begin{array}{l}\text { Aspectos de } \\
\text { Comparação }\end{array}$ & SIPOC & Blueprint & $\begin{array}{l}\text { Mapa de } \\
\text { Consumo }\end{array}$ & $\begin{array}{c}\text { Carta de } \\
\text { Atividades }\end{array}$ & SERVPRO \\
\hline $\begin{array}{l}\text { Grau de } \\
\text { detalhamento do } \\
\text { fluxo de atividades } \\
\text { do consumidor }\end{array}$ & Baixo & Médio & Médio & Alto & Médio \\
\hline $\begin{array}{l}\text { Grau de } \\
\text { detalhamento dos } \\
\text { caminhos } \\
\text { alternativos do } \\
\text { processo }\end{array}$ & Baixo & Médio & Médio & Médio & Alto \\
\hline $\begin{array}{l}\text { Caracterização do } \\
\text { contato do } \\
\text { consumidor com a } \\
\text { empresa }\end{array}$ & $\begin{array}{l}\text { Somente } \\
\text { descrição } \\
\text { textual }\end{array}$ & $\begin{array}{c}\text { Indica } \\
\text { graficamente } \\
\text { momento e } \\
\text { forma de } \\
\text { contato e } \\
\text { enumeras } \\
\text { evidências } \\
\text { físicas } \\
\end{array}$ & $\begin{array}{l}\text { Indica } \\
\text { graficamente } \\
\text { momento e } \\
\text { forma de } \\
\text { contato }\end{array}$ & $\begin{array}{l}\text { Somente } \\
\text { descrição } \\
\text { textual }\end{array}$ & $\begin{array}{c}\text { Somente } \\
\text { descrição } \\
\text { textual (no } \\
\text { diagrama) }\end{array}$ \\
\hline $\begin{array}{l}\text { Grau de } \\
\text { detalhamento do } \\
\text { contato do } \\
\text { consumidor com a } \\
\text { empresa }\end{array}$ & $\begin{array}{l}\text { De nulo a } \\
\text { médio }^{5}\end{array}$ & Alto & Médio & Baixo & $\begin{array}{l}\text { Médio (no } \\
\text { documento de } \\
\text { elaboração) }\end{array}$ \\
\hline $\begin{array}{l}\text { Medição do tempo } \\
\text { dedicado pelo } \\
\text { consumidor }\end{array}$ & Não & Não & Sim & Sim & Não \\
\hline $\begin{array}{l}\text { Medição do tempo } \\
\text { gasto pelo } \\
\text { consumidor com } \\
\text { desperdícios }\end{array}$ & Não & Não & Sim & Sim & Não \\
\hline $\begin{array}{l}\text { Medição da } \\
\text { satisfação do } \\
\text { consumidor com o } \\
\text { processo }\end{array}$ & Não & Não & Sim & Não & Não \\
\hline $\begin{array}{l}\text { Recursos } \\
\text { necessários ao } \\
\text { consumidor }\end{array}$ & Sim & Não & $\begin{array}{c}\text { Indica } \\
\text { parcialmente }\end{array}$ & $\begin{array}{c}\text { Indica } \\
\text { parcialmente }\end{array}$ & Sim \\
\hline
\end{tabular}

\section{Legenda:}

Grau de aderência alto ao aspecto analisado

Grau de aderência intermediário ao aspecto analisado

Grau de aderência baixo ou nulo ao aspecto analisado 
Na Tabela 4, uma escala de cores foi adotada para caracterizar o grau de aderência das ferramentas de mapeamento aos aspectos analisados. Desta forma, o cinza escuro indica que a ferramenta considerada apresenta um alto grau de aderência ao aspecto elencado, enquanto a cor cinza claro representa que esta aderência é parcial e o branco indica que a aderência é baixa ou inexistente.

Conforme se pode observar, cada ferramenta, devido às suas características apresenta vantagens ou desvantagens próprias. Destarte, é preciso avaliar a necessidade de cada caso em que se pretenda mapear um processo de serviço, para se determinar a melhor abordagem de construção de um mapa de processos do consumidor.

Enquanto a ferramenta SIPOC destaca-se por permitir apresentar de forma detalhada os recursos necessários para realização de cada tarefa de um processo, a ferramenta Blueprint trata com profundidade a forma e grau de contato entre consumidor e empresa. Em um Blueprint, nos pontos em que uma linha conectora das atividades do processo cruza a linha de visibilidade os momentos de interação entre consumidor e empresa são facilmente visualizados. Ademais, o Blueprint permite detalhar evidências físicas do processo que influem na tangibilização da prestação do serviço.

O Mapa de Consumo se diferencia por apresentar a medição do tempo para execução do processo e o grau de incômodo (ou satisfação) do consumidor em relação a cada tarefa que executa. Conforme resume a Tabela 4 esta ferramenta apresenta para todos os aspectos comparados um grau de aderência alto ou intermediário. Em comparação com o SIPOC e Blueprint, o Mapa de Consumo se destaca, pois além de permitir a inserção do tempo do processo e grau de satisfação do consumidor, contempla ainda que de forma parcial, todos os demais aspectos abordados na Tabela 4.

Quanto à Carta de Atividades, esta ferramenta identifica o tempo gasto pelo consumidor para execução das tarefas e o tempo que o mesmo permanece em espera aguardando a empresa concluir suas tarefas, podendo ser aplicada quando se exige um alto grau de detalhamento na visão do processo. 
Por fim, a ferramenta SERVPRO desenvolvida por Santos e Varvakis (2002) não apenas evidencia quando as etapas de um processo não prosseguem sequencialmente (e.g. podem ocorrer em paralelo), como aponta as ações e reações executadas pelo cliente e pela empresa quando estes interagem e define medidas de desempenho para avaliar a qualidade do serviço.

Com o propósito de promover o avanço do conhecimento sobre a construção de mapas que contemplem a participação do consumidor no processo de serviço, esta pesquisa irá se voltar mais especificamente para a aplicação da ferramenta do Mapa de Consumo em casos reais.

Apesar de Womack e Jones (2006) proporem a adoção do Mapa de Consumo combinado com o Mapa de Provisão, que mapeia as atividades executadas pela empresa provedora do serviço, esta pesquisa limita-se a avaliar, especificamente, a aplicação do Mapa de Consumo em casos reais. Tal foco no Mapa de Consumo se justifica pelo objetivo proposto de se avaliar a real viabilidade de construção de um mapa que possibilite a visualização da participação do consumidor em processos de serviço.

Ademais, parece lícito admitir que a construção do Mapa de Provisão pelas empresas envolve menor complexidade que a construção do Mapa de Consumo, pois depende integralmente de dados internos da organização. Além disto, o mapeamento das atividades executadas pelas próprias empresas se encontra amplamente difundido no meio empresarial e na literatura técnica científica. Uma vasta quantidade de publicações que tratam da sua aplicação no âmbito das organizações, muitos baseados em casos reais identificados em diversos setores e tipos de processos, evidenciam que a sua prática já se encontra bastante consolidada.

\subsection{DEMAIS FERRAMENTAS DE MAPEAMENTO}

Além dos mapas que registram o fluxo de atividades sequenciais ao longo do tempo, existem ferramentas de mapeamento que mostram as relações entre os agentes 
envolvidos no processo de serviço. Nesta seção, são apresentadas as ferramentas identificadas na literatura que não tratam do processo com uma visão temporal de seu fluxo, mas enfatizam a visualização dos agentes envolvidos e afetados pelo processo destacando, inclusive, as interfaces com o consumidor.

\subsubsection{Análise da Cadeia de Valor do Consumidor (customer value chain analysis)}

A Análise da Cadeia de Valor do Consumidor (Customer Value Chain Analysis CVCA) é uma técnica proposta por Donaldson, Ishii e Sheppard (2006) para mapear as relações entre as partes envolvidas na cadeia de valor de um dado serviço ou produto durante seu ciclo de vida.

A visualização da cadeia de valor do consumidor permite identificar possíveis interações do consumidor com o processo de desenvolvimento de um produto $\mathrm{e}$, portanto, serve como um método para apoiar a coleta da voz do consumidor e de suas expectativas em relação ao processo de serviço e ao resultado do serviço. $\mathrm{Na}$ Figura 20 pode-se observar a sequência de passos propostos por Donaldson, Ishii e Sheppard (2006) para aplicar a CVCA no mapeamento de uma cadeia de valor. Nesta figura, a cadeia de valor entre um fabricante de máquinas de venda por autoatendimento para venda de petiscos e refrigerantes e consumidores finais de destes produtos é desenhada considerando os seguintes passos:

a. Passo 1: Determinar o modelo de negócio para a máquina de venda;

b. Passo 2: Delimitar as partes envolvidas no ciclo de vida da máquina de vendas;

c. Passo 3: Determinar como cada parte envolvida se relaciona com as outras;

d. Passo 4: Identificar o que é valor para cada uma das partes envolvidas e o fluxo existente entre elas;

e. Passo 5: Analisar a cadeia de valor do consumidor, determinando quais as etapas do processo que podem gerar dúvidas e reclamações do consumidor afetando as proposições de valor. 
No fluxo apresentado na Figura 20, o operador de vendas e o fabricante de refrigerantes (engarrafadora) foram determinados como agentes (partes envolvidas) críticos no ciclo de vida da máquina de vendas.

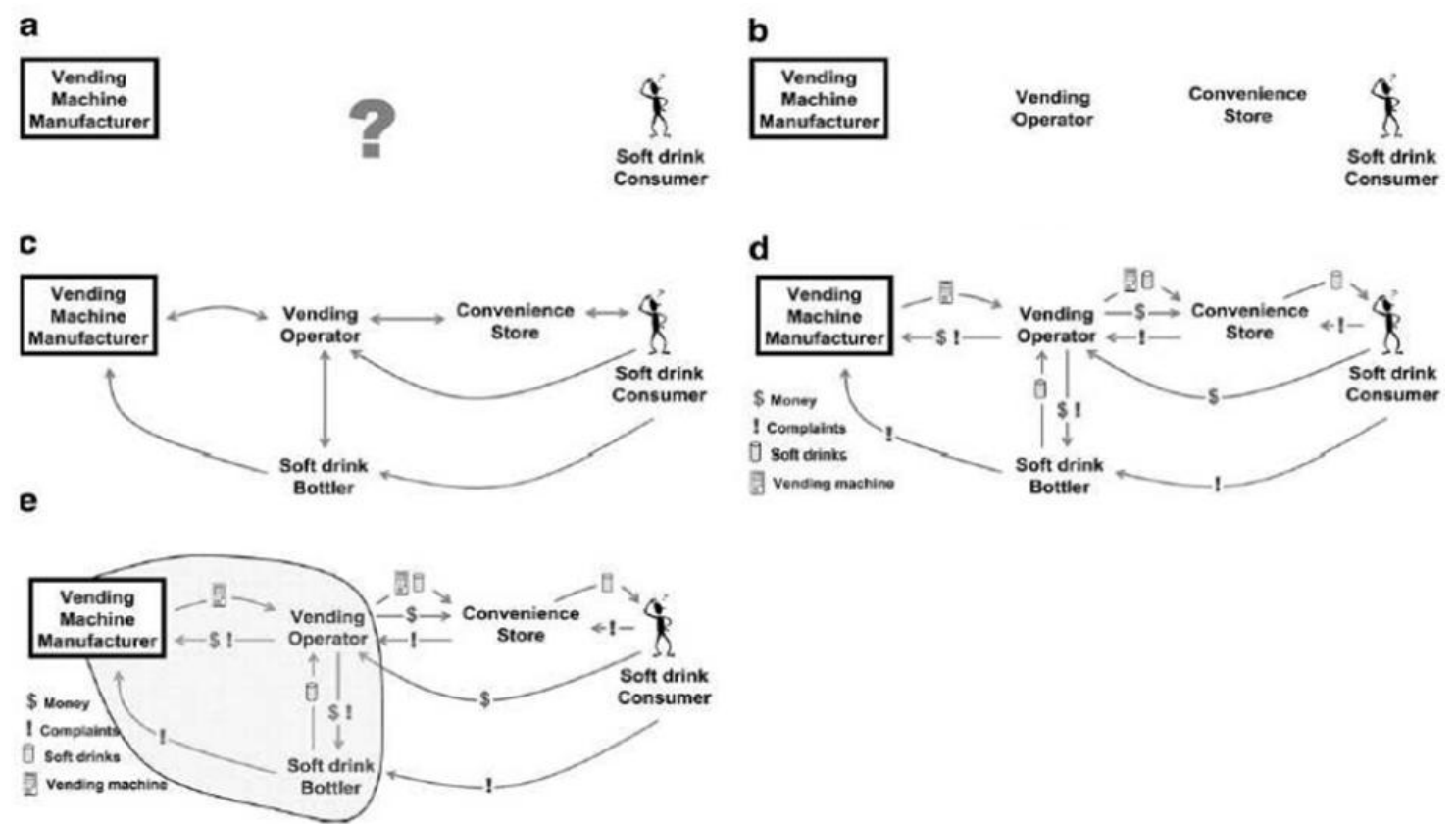

Figura 20 - Utilização da cadeia de valor do consumidor para visualização das relações entre as partes envolvidas no ciclo de vida do produto

Fonte: Donaldson, Ishii e Sheppard (2006 p. 177)

Conforme se evidencia, Donaldson, Ishii e Sheppard (2006) utilizam certos símbolos para representar a ocorrência de transferências financeiras (pagamentos) e reclamações no ciclo de vida de um produto. A incidência de ônus financeiro é representada por um cifrão (\$) e de uma reclamação por uma exclamação (!).

\subsubsection{Rede de Relacionamento}

Segundo GUMMESSON (2008a, p. 150) assim como provedores de bens e serviços procuram continuamente avaliar e racionalizar sua cadeia de valor, a cadeia de valor do consumidor (customer value chain) também precisa ser estudada e melhorada para se tornar mais eficiente sob a lógica e ponto de vista do consumidor. 
Baseado nesta premissa, este autor propõe a aplicação da ferramenta de Rede de Relacionamento (Network) como um meio de visualização da participação do consumidor num processo de serviço.

Esta ferramenta possibilita a visualização dos agentes envolvidos e impactados no entorno de um consumidor que se relaciona com o fornecedor de um dado produto. O consumidor e produto ou serviço são posicionados no centro da Rede de Relacionamento e, a partir desta relação, são explicitados por meio de nós (círculos) os demais agentes envolvidos no processo, empresa provedora do produto ou serviço e demais consumidores em potencial.

No exemplo de Rede de Relacionamento, apresentado na Figura 21, os respectivos nós são interligados por arcos que conectam o cliente a empresa fabricante, comercializadora e transportadora do freezer e às pessoas que o auxiliaram a armazenar temporariamente os alimentos do cliente para que estes não estragassem devido à quebra do freezer.

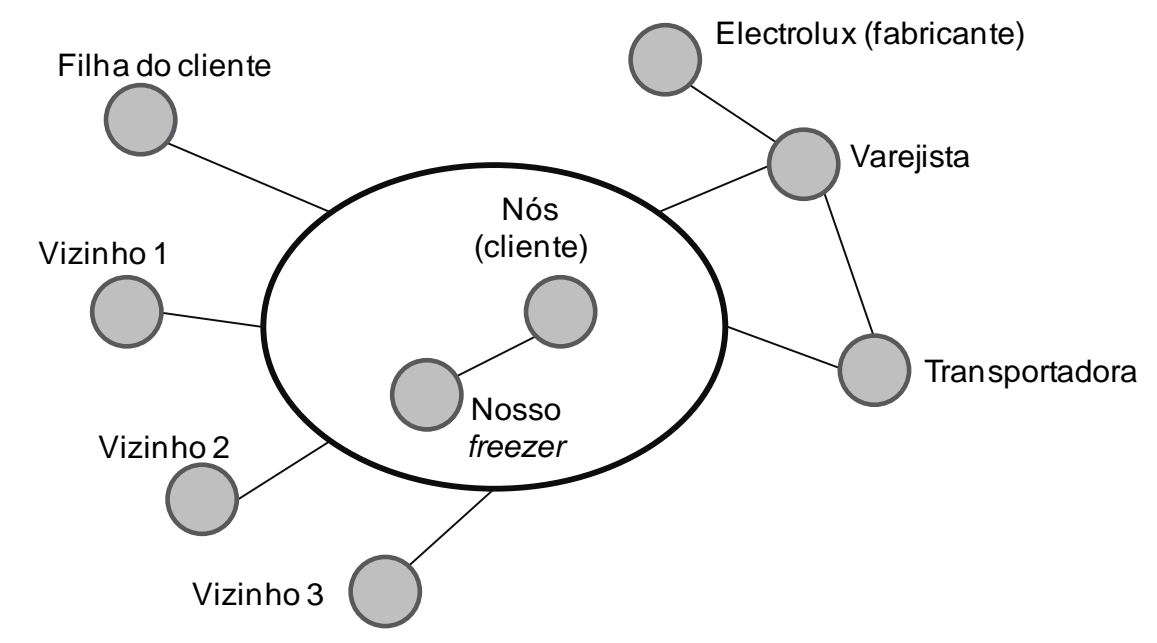

Figura 21 - Rede de Relacionamentos decorrentes da quebra de um freezer Fonte: Adaptada de Gummesson (2008a, p. 147)

Gummesson (2008a) utilizou o caso da quebra de um freezer para desenvolver um estudo de caso que relata a difícil experiência de um consumidor que busca a resolução de um problema. O autor mostra o esforço desempenhado pelo consumidor para ter seu problema solucionado e a Rede de Relacionamento que acaba envolvida pela quebra do produto. 
Conforme indica a Figura 21 a quebra do freezer não se limitou a impactar somente a família proprietária do produto, pois implicou na necessidade de recorrer a mais pessoas para evitar a deterioração dos alimentos.

Esta forma de mapeamento facilita a visualização que as falhas de um bem ou um serviço podem causar quando seus efeitos ultrapassam as fronteiras de relacionamento do consumidor com seu provedor e atinge outras partes. Isto ajuda a destacar a necessidade de análise de processos e interações do tipo Business-toCustomer (B2C) e Customer-to-Business (C2B) entre empresas e seus clientes, não negligenciar possíveis implicações entre estes clientes e outros consumidores via suas conexões sociais do tipo Customer-to-Customer (C2C). 


\section{MÉTODOS DE PESQUISA}

Neste capítulo são apresentados os procedimentos metodológicos adotados no desenvolvimento da pesquisa, visando a elucidação das questões propostas.

O desenvolvimento deste trabalho parte da necessidade de entender como as empresas podem agregar maior valor aos consumidores através do aumento da qualidade do processo do consumidor e através da redução do custo para o consumidor justifica (ver seção 1.4). Os consumidores atuam participativamente nos processos de serviço e por diversas vezes encontram dificuldades para obter o resultado esperado. Tais dificuldades, como, por exemplo, a necessidade de alocação de mais tempo para execução do serviço, a necessidade de maior treinamento e capacitação, a necessidade de despender mais recursos para poder ter acesso ao serviço e a necessidade de deslocamento constituem um ônus do consumidor no processo de serviço.

O problema de pesquisa que motiva este estudo (ver seção 1.2) aponta que existe uma lacuna no conhecimento a respeito da aplicação e difusão das ferramentas de mapeamento que identificam e medem as atividades executadas pelos consumidores.

Diante do problema focado foram levantadas quatro questões de pesquisa. Com as questões apresentadas esta pesquisa objetiva entender:

- como a construção de mapas das atividades e tarefas dos consumidores é abordada pela literatura (Q1);

- como a construção de um Mapa de Consumo pode ser aplicado em casos reais (Q2);

- como medir o esforço e satisfação do consumidor em relação a sua coprodução no processo produtivo (Q3) e;

- quais seriam as possíveis dificuldades na elaboração de um Mapa de Consumo quando aplicado em casos práticos (Q4). 
Frente aos objetivos desta pesquisa na qual se pretende estudar uma técnica de mapeamento pouco difundida (MIGUEL, 2007), adotou-se uma abordagem de pesquisa de natureza exploratória iniciando com uma varredura na literatura a respeito das ferramentas de mapeamento e medição das atividades dos consumidores.

O trabalho prossegue com uma pesquisa de campo para avaliar a viabilidade e o esforço para se construir o Mapa de Consumo em casos reais. Desta forma pretende-se contribuir para um melhor entendimento do método de construção e aplicação do Mapa de Consumo que, apesar de ter sido proposto em 2006 por Womack e Jones tem sido pouco abordado no campo acadêmico e, no campo empresarial, iniciativas de sua efetiva adoção ainda são desconhecidas. Nesta pesquisa, procurar-se-á avaliar o processo empírico de mapeamento da participação do consumidor no qual o resultado da construção do Mapa de Consumo será tratada como uma variável qualitativa. A resultante da pesquisa de campo pode, portanto, trazer três tipos de saída:

(i) obtenção de um Mapa de Consumo completo;

(ii) obtenção de um Mapa de Consumo parcial e

(iii) constatação de não ser possível construir o Mapa de Consumo.

Apesar do estudo em questão pautar-se essencialmente em uma abordagem qualitativa, pela qual serão coletados dados de diversas fontes de informação para construção de um mapa de processo, alguns dados quantitativos serão coletados para servirem de insumo para construção do Mapa de Consumo (medição das atividades executadas pelos consumidores) e para se avaliar o esforço e dificuldades de sua construção (tempo gasto pela pesquisadora para coleta de dados, adesão dos consumidores ao esforço de coleta de dados).

Considera-se que existem duas principais fontes de dados que poderiam contribuir para a construção de um Mapa de Consumo: a empresa e o consumidor. A fim de avaliar as implicações da necessidade de envolvê-los no esforço de construção de um Mapa de Consumo serão adotados os seguintes métodos de pesquisa: estudo de caso, experimento e enquete. 
Vale ressaltar que a adoção destes métodos de pesquisa tem como propósito explorar a viabilidade de construção do Mapa de Consumo através de uma pesquisa de campo (FLYNN et. al., 1990), não havendo, portanto, a pretensão de analisar em profundidade a relação causal entre variáveis específicas dos casos práticos selecionados. Ou seja, não se pretende entender nesta pesquisa, por exemplo, por que um consumidor demora mais tempo ou se sente mais insatisfeito em relação a um processo específico, mas sim avaliar se empresa e consumidores conseguem contribuir na construção do Mapa de Consumo e se a aplicação do mesmo é viável para casos reais de processos únicos.

A consideração de processos únicos, sem muitas ramificações, nos quais um único serviço é adquirido e executado de cada vez visa avaliar a aplicabilidade da ferramenta Mapa de Consumo para processos de menor complexidade. Desta forma, pretende-se seguir a lógica de verificar as dificuldades advindas da aplicação desta ferramenta quando associadas a processos mais simples e com menor tempo de duração das tarefas (tal como o fluxo genérico de compra pela internet, "Comprar via Web", considerado por Womack e Jones (2006, p. 153) que abrange atividades com duração de 17 minutos) para, posteriormente, vislumbrar a sua aplicabilidade em casos mais complexos (tal como o fluxo em que o proprietário de um veículo procura tê-lo reparado por uma concessionária, representado na Figura 12, que abrange atividades com duração de 210 minutos ao longo de mais de um dia).

A primeira questão de pesquisa (Q1) é tratada pelo método de revisão da literatura. Nesta revisão foram pesquisados artigos que fornecessem um panorama do tema de pesquisa (MIGUEL, 2007) levantando-se as ferramentas de mapeamento abordadas pela literatura que servem para mapear a participação de consumidores em processos de serviço.

A segunda, terceira e quarta questões (Q2, Q3, Q4) direcionam o estudo para uma pesquisa de campo em que diferentes métodos de pesquisa serão utilizados a fim de avaliar a empresa e os consumidores como fonte de dados para construção do Mapa de Consumo em casos reais.

Os casos reais a serem selecionados para estudo serão restritos a casos constituídos de um fluxo único de serviço, ou seja, envolvem processos sem muitas 
ramificações, nos quais não ocorram serviços paralelos e simultâneos. Com efeito, privilegia-se um processo de serviço singular e padronizado. Ademais, os casos a serem estudados não podem ser fluxos de exceções, mas sim processos corriqueiros, executados por grande número de consumidores, que sigam padrões de funcionamento e que, portanto, possam ser medidos diversas vezes com um mesmo consumidor ou com consumidores diferentes.

Dentre as categorias de processo de serviços existentes, delimitou-se o escopo desta pesquisa aos processos de serviço sem interação usual entre o consumidor e o funcionário da empresa provedora do serviço, denominado serviço "faça você mesmo" (JOHNSTON; CLARK, 2002), conforme se visualiza na Figura 22. Neste tipo de serviço, o consumidor apresenta um alto grau de envolvimento, por ter de ele mesmo executar as tarefas do processo para atingir o resultado esperado do serviço.

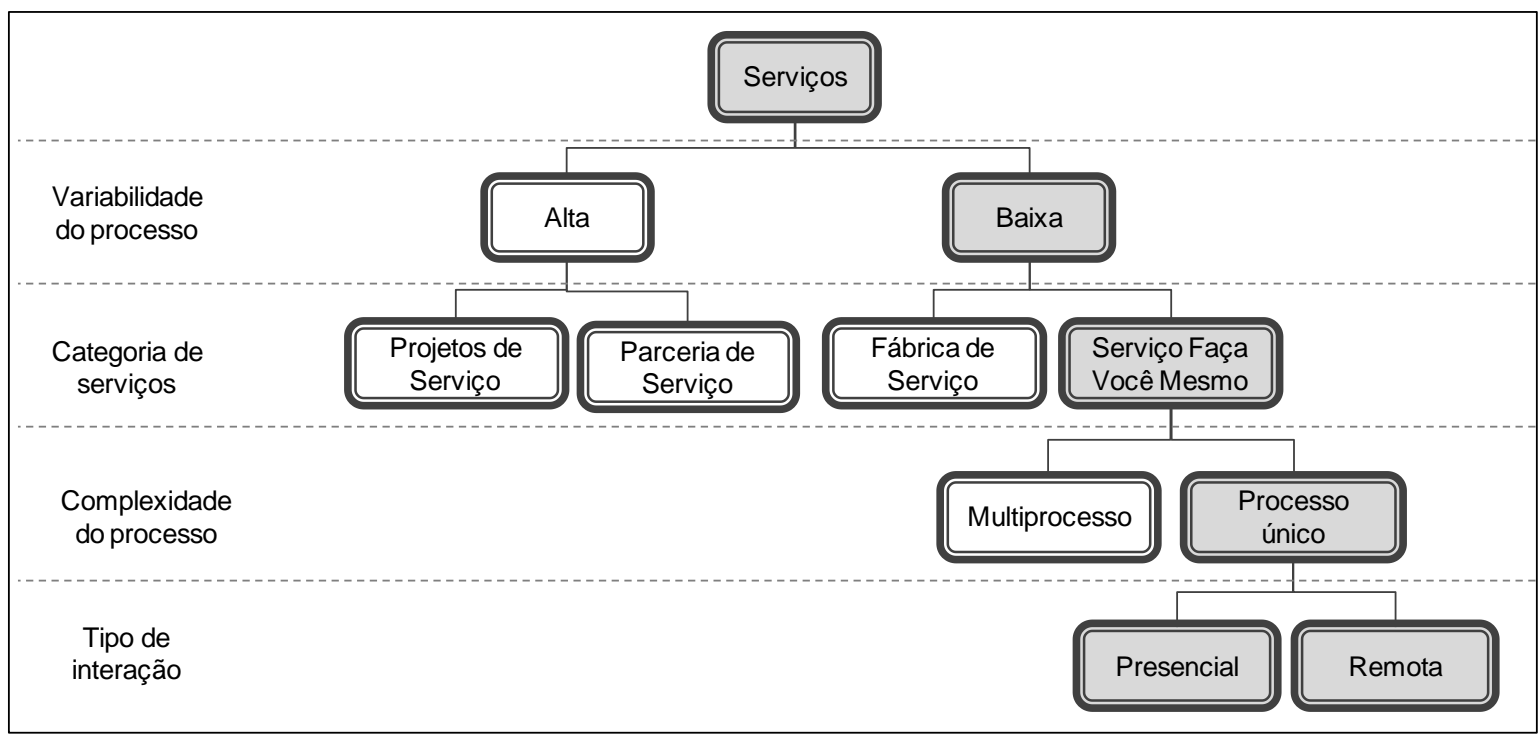

\section{Legenda}

$\square$ Dentro do escopo de pesquisa

Fora do escopo de pesquisa

Figura 22 - Delimitação do escopo da pesquisa

A escolha deste tipo de processo de serviço foi motivada por dois fatores principais. O primeiro se deve ao alto grau de envolvimento do consumidor e o segundo, à 
baixa interação existente entre consumidor e funcionário da empresa provedora do serviço.

A adoção deste tipo de processo implica em explorar um processo no qual o consumidor é o agente principal para execução das tarefas e, desta forma, necessita empenhar seus recursos e conhecimentos para possibilitar a concretização do serviço. Desta forma, pode-se explorar mais enfaticamente como o mapeamento e medição das tarefas dos consumidores podem ser realizadas em casos reais.

O outro critério que restringiu a pesquisa aos processos "faça você mesmo" é o fato de não haver interação direta entre o consumidor e os funcionários da empresa prestadora do serviço. A interação entre as pessoas gera um critério altamente subjetivo na avaliação do serviço, podendo contribuir positiva ou negativamente para a satisfação do cliente e assim influir na percepção do cliente em relação ao custo para aquisição do serviço.

Através da análise do processo sem interação usual entre consumidor e funcionário, esta pesquisa busca isolar os fatores de empatia e capacidade de relacionamento entre as partes do processo, mapeando e medindo as tarefas do consumidor com base em dados tangíveis e mensuráveis. Portanto, neste estudo, o custo para o cliente - a magnitude do esforço exercido pelo consumidor que compõe a sua percepção de valor - será medido em tempo.

Foram selecionados dois tipos de processos classificados como "faça você mesmo" com fluxo único: um com interação remota e outro com interação presencial. Para cada tipo de processo será selecionado um caso real que se enquadre nas características do mesmo.

A proposta de pesquisar os tipos de serviço "faça você mesmo" com interação remota e com interação presencial também direcionou a adoção de métodos de pesquisa específicos como descrito a seguir:

(i) Para o serviço "faça você mesmo" com interação remota os métodos de pesquisa selecionados foram estudo de caso e experimento.

a. Estudo de Caso: por meio do estudo de um caso real pretende-se avaliar como uma empresa pode levantar informações para viabilizar a 
construção do Mapa de Consumo. A empresa escolhida para o estudo de caso deve utilizar algum sistema para rastrear/monitorar as tarefas executadas remotamente pelo consumidor no qual seja possível levantar dados do tempo gasto por este no processo de serviço. $O$ estudo de caso apoiar-se-á em entrevistas, consulta às bases de dados da empresa e observação direta do processo para permitir a coleta de dados necessários à construção do Mapa de Consumo.

b. Experimento: em contrapartida ao estudo de caso, em que serão coletados dados para o Mapa de Consumo através da empresa provedora do serviço, por meio do experimento pretende-se utilizar o consumidor como fonte de dados. Com base na observação direta do processo a ser mapeado será desenvolvida uma planilha de medição de tempos do processo, considerando as especificidades do serviço selecionado para esta pesquisa. Esta planilha será fornecida a consumidores que utilizam o serviço objeto de estudo para que os mesmos preencham-na durante a execução das tarefas sob sua responsabilidade. Considera-se que o experimento aplicado utilizando uma planilha padronizada para registro de dados do processo seja a forma mais adequada de se coletar dados com a colaboração do consumidor, pois como o processo é executado remotamente seria inviável o pesquisador estar presente durante o processo de serviço.

(ii) Para o serviço "faça você mesmo" com interação presencial considera-se viável a observação direta do consumidor e a aplicação de um questionário em forma de enquete.

a. Observação direta: A empresa (representada nesta pesquisa pelo pesquisador que exerce o papel de responsabilidade da organização provedora do serviço) pode observar, anotar e medir as tarefas do consumidor identificando dificuldades e pontos de melhoria na prestação do serviço uma vez que neste tipo de serviço o cliente está presente em suas instalações.

b. Enquete: O método de pesquisa enquete será adotado em um processo de serviço real por meio de uma entrevista com os consumidores logo após a execução do serviço. Procurar-se-á não interferir diretamente na atuação do consumidor a ser entrevistado. 
Com o objetivo de avaliar os mapas de consumo resultantes desta pesquisa considerando o modelo de representação estabelecido por Womack e Jones (2006), alguns critérios de comparação foram definidos. Os critérios baseiam-se nos aspectos a serem observados ao longo dos passos que devem ser seguidos para a construção do Mapa de Consumo conforme explicitado na seção 2.1.3 e no esquema visual apresentado na Figura 12 e estão sintetizados no seguinte check list:

a. Fluxo do processo detalhando as tarefas desempenhadas pelo consumidor;

b. Forma de interação entre consumidor e empresa;

c. Tempo gasto pelo consumidor para execução das tarefas;

d. Grau de satisfação ou incômodo do consumidor;

e. Segregação dos tempos em que há e não há agregação de valor.

O intuito da definição destes critérios para construção do Mapa de Consumo é que sirvam de check list na comparação dos mapas resultantes da pesquisa de campo a ser realizada neste estudo. Desta forma, pretende-se avaliar os métodos de coleta de dados adotados por esta pesquisa a fim de verificar se foram assertivos em levantar os dados necessários para construção de um Mapa de Consumo abrangente que incorpore aspectos chave do padrão de representação introduzido por Womack e Jones (2006).

\subsection{PROCESSO COM INTERAÇÃO REMOTA}

O primeiro processo refere-se a um serviço executado remotamente, no qual o consumidor não necessita deslocar-se até a empresa provedora do serviço, podendo executar o processo de serviço em qualquer lugar desde que possua acesso a internet. O serviço tomado como objeto de estudo foi um de Compra Coletiva, que será explicado de forma mais detalhada no Capítulo 4. Para o desenvolvimento deste estudo, foi selecionada como unidade de análise um serviço em massa, de alto volume, do tipo "faça você mesmo" e com fluxo de execução único conforme a delimitação do escopo desta pesquisa. 
Os serviços disponíveis pela internet, também denominados serviços eletrônicos (ZEITHAML; BITNER, 2003) possuem características próprias. Zeithaml e Bitner (2003) apontam que os bons sites da internet são aqueles que apresentam:

a. Responsividade elevada: velocidade de resposta do site (na transição entre as páginas da internet) e das informações solicitadas à empresa pelo cliente.

b. Facilidade de navegação: usabilidade do site, que com uma estrutura intuitiva e consistente possibilita rápida identificação das informações necessárias para consumo do serviço pelo cliente.

C. Eficácia: está atrelada ao resultado do serviço e ao custo para adquiri-lo. Refere-se à avaliação do cliente em relação a processo do consumidor comparando o esforço desempenhado para adquirir o serviço versus a satisfação com o resultado alcançado.

d. Experiência: satisfação do cliente em acessar e navegar pelo site.

Voss (2000) contribui nesta discussão enumerando seis fatores que influem na qualidade dos serviços prestados pela internet conforme seguem:

a. resposta rápida: obtenção de informações e do próprio serviço em minutos;

b. resposta automática: confirmação instantânea das transações realizadas na web;

c. comunicação com o cliente: permite obter informações a respeito do tempo de atendimento, entrega;

d. acompanhamento por telefone: disponibilidade de outros meios de contato com a empresa;

e. habilidade de checagem de status: acompanhamento do serviço através da web;

f. links para perguntas mais frequentes dos clientes.

Estes fatores que qualificam os sites da internet estão em grande parte atrelados à percepção do cliente na execução de tarefas por este meio de comunicação. A 
forma como as tarefas são expostas para que sejam executadas pelos clientes, a rapidez, facilidade e forma de comunicação dos sites influenciam a percepção de valor em relação ao serviço.

Por outro lado, apesar da relevância dos fatores apresentados e dos benefícios que proporciona, Zeithaml e Bitner (2003) destacam que ainda existem muitos desafios em relação aos serviços eletrônicos, conforme sugere a relação apresentada na Tabela 5.

Tabela 5 - Benefícios e desafios dos serviços eletrônicos

\begin{tabular}{ll}
\hline \multicolumn{1}{c}{ Benefícios } & \multicolumn{1}{c}{ Desafios } \\
\hline & • Os clientes são ativos, não passivos \\
& • Falta de controle do ambiente eletrônico \\
- Execução efetiva de serviços & - Competição por preço \\
padronizados & - Falta de flexibilidade para customizar no caso \\
- Baixo custo & de serviços altamente padronizados \\
- Conveniência para o cliente & - Falta de consistência em função do \\
- Distribuição ampla & envolvimento do cliente \\
- Opções de customização por parte do & - Requer alterações no comportamento do \\
cliente & consumidor \\
- Retorno rápido para o cliente & - Preocupações com segurança \\
& - Competição decorrente da ampliação da \\
& abrangência geográfica \\
\hline
\end{tabular}

Fonte: Zeithaml e Bitner (2003 p. 318)

Para superar desafios como a participação ativa do cliente, a falta de consistência do processo devido ao envolvimento do cliente e a necessidade de alterações no comportamento dos consumidores faz-se necessário desenvolver uma análise critica das tarefas desempenhadas pelos consumidores. E, portanto, por meio do mapeamento e medição das tarefas dos consumidores pode-se contribuir para uma análise crítica do processo em um serviço eletrônico a fim de identificar oportunidades e meios para poder oferecer maior valor ao consumidor e enfrentar alguns desafios existentes neste tipo de serviço.

A seguir são detalhados os métodos de pesquisa de estudo de caso e experimento adotados para a consideração do mapeamento no contexto deste tipo de serviço. 


\subsubsection{Estudo de Caso}

A adoção do método de estudo de caso teve como propósito avaliar a empresa como fonte de dados para construção do Mapa de Consumo, de forma que este mapa possa ser baseado em dados coletados internamente. Por se tratar de um processo remoto em que o cliente executa as tarefas através de um site da empresa prestadora do serviço, adotou-se como premissa que a empresa poderia rastrear as tarefas dos consumidores medindo seu esforço de participação no processo de compra coletiva.

O método de estudo de caso busca responder questões do tipo o que, como e por que determinados fenômenos acontecem. Isso motiva sua adoção a fim de verificar como aplicar uma ferramenta como o Mapa de Consumo em casos reais e, ainda, elencar as possíveis dificuldades enfrentadas no mapeamento e medição das tarefas do consumidor. Ademais, por se tratar de um método que estuda variáveis em seu ambiente natural, permite observar a aderência das organizações à prática de realizar este tipo de mapeamento, bem como o grau de preocupação/interesse delas em facilitar o processo do consumidor (VOSS; TSIKRIKTSIS; FROHLICH, 2002; MIGUEL, 2010).

Os levantamentos de dados para o estudo de caso foram realizados por meio de entrevistas, observação do processo in loco pela pesquisadora e análise de base de dados da empresa com o objetivo de confirmar a consistência das informações coletadas e dos resultados alcançados (EISENHARDT, 1989).

Um dos meios de coleta de dados foram as entrevistas presenciais e remotas (com troca de informações por e-mails) com o dono e administrador da empresa de compra coletiva estudada, realizadas pela pesquisadora por meio de perguntas abertas (APÊNDICE A). Outra fonte de dados foram os relatórios gerenciais da empresa que a pesquisadora foi autorizada a consultar o que permitiu que dados quantitativos a respeito do processo de compra coletiva fossem extraídos de registros históricos. Os dados levantados nestes relatórios são secundários (MIGUEL, 2010). 
O estudo de caso consistiu em um levantamento detalhado e profundo da empresa estudada, com o intuito exploratório (VOSS; TSIKRIKTSIS; FROHLICH, 2002). A adoção deste método de pesquisa neste trabalho teve como propósito testar a aplicação da ferramenta de mapeamento do consumo tal como proposto por Womack e Jones (2006). Os resultados que se procurou obter com este método de pesquisa são explicitados no Quadro 2.

Quadro 2 - Resultados que se procurou obter com o estudo de caso

a. Construção do Mapa de Consumo:

(i) obtenção de um Mapa de Consumo completo: contém todas as informações propostas pelo modelo de representação de Womack e Jones (2006);

(ii) obtenção de um Mapa de Consumo parcial: é parcialmente aderente ao modelo de representação;

(iii) constatação de não ser possível construir o Mapa de Consumo: não é possível construir um mapa tal como o modelo de representação prescreve.

b. Analisar que dados atrelados à participação do consumidor no processo são coletados pela empresa prestadora do serviço e qual a relevância destes dados para a empresa provedora do serviço.

c. Tempo dedicado pela pesquisadora para obter os dados

Em paralelo à coleta de dados junto à empresa provedora do serviço, foi conduzido um experimento para verificar a possibilidade de coleta de dados utilizando como fonte o próprio consumidor.

\subsubsection{Experimento}

Usualmente os experimentos são aplicados para avaliar a relação de causa e efeito entre variáveis (MIGUEL, 2007; MARCONI; LAKATOS, 2003) respondendo questões do tipo por que e como (MIGUEL, 2010). Nesta pesquisa, o intuito da utilização do 
experimento é de aprofundar o estudo empírico sobre a aplicabilidade da ferramenta Mapa de Consumo em casos reais utilizando como fonte de dados o consumidor. A utilização do experimento possibilita, ainda, comparar a qualidade das informações obtidas por este método em relação à qualidade das informações obtidas pelo estudo de caso.

O experimento de campo possibilita a manipulação e controle de algumas variáveis em seu ambiente natural de forma a se observar os resultados atingidos, sendo útil para a construção e validação de teorias (FLYNN et al., 1990). No processo de compra coletiva em estudo, as características do processo que foram levadas em consideração podem ser verificadas no

Quadro 3.

Quadro 3 - Características consideradas no experimento

a. Tipo de processo de serviço: processo padronizado com interação remota, conforme o escopo delimitado nesta pesquisa;

b. Empresa provedora do serviço;

c. Familiaridade do consumidor com o processo: primeira compra pelo site ou não;

d. Forma de pagamento: débito em conta ou cartão de crédito;

e. Tempo do consumidor dedicado ao processo.

Os resultados que se pretende conseguir com a realização do experimento são elencados no Quadro 4. 
Quadro 4 - Resultados que se pretende obter com o experimento

a. Construção do mapa de consumo:

(i) obtenção de um Mapa de Consumo completo: contém todas as informações propostas pelo modelo de representação de Womack e Jones (2006);

(ii) obtenção de um Mapa de Consumo parcial: é parcialmente aderente ao modelo de representação;

(iii) constatação de não ser possível construir o Mapa de Consumo: não é possível construir um mapa tal como o modelo de representação prescreve.

b. Grau de adesão dos consumidores à pesquisa;

c. Qualidade dos dados coletados, ou seja, percentual de dados obtidos que foram coletados corretamente e puderam ser utilizados;

d. Tempo dedicado pela pesquisadora para obter os dados.

Uma variável deste experimento que não pôde ser controlada ou isolada foi a habilidade/agilidade do consumidor em lidar com sites de compra coletiva. Esta variável pode influenciar o tempo de execução da tarefa.

A amostra deste experimento não foi determinada estatisticamente, o que não invalida a utilização dos dados obtidos para ilustrar a construção do mapa do processo. Como o serviço de compra coletiva é executado pelo consumidor remotamente foi necessário desenvolver uma planilha de medição e um manual de instrução (APÊNDICE C) para orientar o consumidor em como realizar o registro dos dados.

A planilha de medição foi desenvolvida pela pesquisadora em Excel com base no seu conhecimento sobre o fluxo do processo de compra coletiva. Versões iniciais da planilha foram testadas por consumidores que colaboraram em experimentos piloto e ajustadas para viabilizar sua utilização por uma amostra maior de consumidores. As primeiras versões da planilha pretendiam coletar medidas de tempo dos consumidores em cada tarefa do processo do consumidor conforme pode ser observado na figura da versão inicial apresentada no APÊNDICE D. No entanto, 
esbarraram na aversão dos consumidores à necessidade de dedicar muita atenção e tempo ao preenchimento e prejudicar o dinamismo de sua interação com o site de compra coletiva devido às muitas interrupções que demandaram.

A versão definitiva da planilha desenvolvida simplificou a forma de medição dos consumidores e foi enviada a consumidores potenciais para que registrassem durante dois meses as compras efetuadas em quaisquer site de compra coletiva. Para não inviabilizar a realização da pesquisa, este estudo não limitou que os experimentos fossem realizados somente com a empresa abordada no estudo de caso, pois foi destinada à coleta de dados reais das experiências dos consumidores em um tempo relativamente curto.

A adoção dos métodos de pesquisa de estudo de caso e experimento possibilitou verificar a aderência da empresa à prática de mapear e medir as tarefas desempenhadas pelo consumidor e o grau de adesão e disposição dos clientes em contribuir com a medição de suas tarefas.

A combinação destes métodos se mostrou necessária para explorar as questões de como proceder o mapeamento das tarefas desempenhadas pelos consumidores (Q2) e de como medir o esforço e satisfação dos mesmos (Q3) em processos de serviço com interação remota. Adicionalmente, a aplicação destes métodos permitiu avaliar as dificuldades enfrentadas na aplicação da ferramenta Mapa de Consumo (Q4) em experiências reais.

\subsection{PROCESSO COM INTERAÇÃO PRESENCIAL}

O segundo tipo de processo a ser estudado também é realizado com muito empenho do consumidor, porém envolve interação presencial, assim, ele necessita se deslocar até o provedor do serviço para a execução das tarefas. O consumidor submete-se a uma interação presencial com a empresa prestadora do serviço, mas a execução das tarefas é de responsabilidade do consumidor que interage com máquinas e com o ambiente, mas não com funcionários da empresa. 
Para caracterizar este tipo de processo foi escolhido para estudo o processo de estacionar o carro em um shopping center (sem a utilização do serviço de vallet). Trata-se de um processo rotineiro, usual para uma grande massa de consumidores, caracterizado por um fluxo único, sujeito a uma elevada demanda que se enquadra na categoria de serviço "faça você mesmo".

Diferentemente do processo com interação remota, neste tipo de serviço o consumidor está no ambiente do provedor, porém executa as tarefas de forma autônoma.

O método adotado para esta categoria de serviço será o levantamento, mais especificamente, uma enquete na qual serão entrevistados consumidores eu puderam ser abordados pela pesquisadora no estacionamento de um shopping center.

\subsubsection{Enquete}

A adoção do método de enquete envolve a coleta de dados a partir de uma base de pessoas das quais se deseja conhecer o comportamento ou se obter a opinião sobre determinado tema (GIL, 1994). Apesar de amplamente difundido para realização de pesquisas de mercado nas empresas este método também apresenta aplicação relevante nas pesquisas acadêmicas (RODRIGUES, 2002; BOTEGA, 1991; CAIXETA et al., 2007).

Freitas e Moscarola (2002) abordam em seu trabalho o potencial do método enquete para se realizar investigações no campo acadêmico e empresarial e mostra como algumas análises de dados podem ser conduzidas. Estes autores tratam da importância do papel do pesquisador na execução da enquete e das habilidades necessárias para abordar o público alvo e obter os dados necessários.

O método de enquete, também denominado enquete operária, busca investigar a realidade por meio de questionários e entrevistas. A execução deste método de pesquisa pode ocorrer de forma ativa ou passiva por parte do pesquisador 
(THIOLLENT, 1982). Na enquete ativa o pesquisador interage com o público pesquisado podendo, eventualmente interferir nos resultados obtidos. Thiollent (1982) aponta que a presença do pesquisador já é um fato que pode acarretar a distorção nas respostas obtidas. $\mathrm{Na}$ enquete passiva, por outro lado, a presença do pesquisador não influencia os fatos, ou porque os acontecimentos ocorreram antes da presença do pesquisador ou porque este não interage com os pesquisados que respondem as perguntas sem entrar em contato com o pesquisador, por exemplo, através de um formulário.

Nesta pesquisa será adotada a observação ativa, na qual a pesquisadora irá abordar os consumidores para coleta de dados de tempo e satisfação. Entretanto, para coleta dos tempos, não ocorrerá qualquer influência do pesquisador nos dados coletados, pois no momento em que a pesquisadora abordar o consumidor 0 processo de estacionar o carro já estará finalizado e a medição do tempo será baseada no sistema de cancela eletrônica instalado no shopping center. Em relação à percepção de incômodo ou satisfação do cliente admitiu-se a premissa de que dificilmente o consumidor se sentiria acuado e manifestaria sua percepção quanto ao processo de estacionar o carro por ele desempenhado diferente da sua real opinião se a pesquisadora dispensasse a identificação do consumidor e esclarecesse os fins acadêmicos do dado a ser coletado. Desta maneira assegurarse-ia que a informação não causaria nenhum transtorno, prejuízo ou exposição ao consumidor abordado.

As características consideradas no levantamento a ser realizado no processo do estacionamento são explicitadas no Quadro 5.

Quadro 5 - Características consideradas na enquete

a. Tipo de processo de serviço: processo padronizado com interação presencial, conforme escopo delimitado nesta pesquisa;

b. Empresa provedora do serviço;

c. Tempo do consumidor dedicado ao processo;

d. Satisfação do consumidor com o processo executado: utilizando a escala de figuras proposta por Womack e Jones (2006) retratada na Figura 14; 
No Quadro 6 são apresentados os resultados que se pretende alcançar com a execução da enquete.

Quadro 6 - Resultados que se pretende obter com a enquete

a. Construção do mapa de consumo:

(i) obtenção de um Mapa de Consumo completo: contém todas as informações propostas pelo modelo de representação de Womack e Jones (2006);

(ii) obtenção de um Mapa de Consumo parcial: é parcialmente aderente ao modelo de representação;

(iii) constatação de não ser possível construir o Mapa de Consumo: não é possível construir um mapa tal como o modelo de representação prescreve.

b. Grau de adesão dos consumidores a pesquisa;

c. Qualidade dos dados coletados, ou seja, percentual de dados obtidos que foram coletados corretamente e puderam ser utilizados;

d. Tempo dedicado pela pesquisadora para obter os dados.

A coleta de dados será realizada pela pesquisadora através de entrevistas presenciais com os consumidores. Os principais dados que se pretende coletar são: tempo dedicado pelo consumidor à execução do processo e sua satisfação.

O tempo gasto pelo consumidor será medido através da diferença entre o horário registrado no ticket de estacionamento que o cliente retira na cancela eletrônica (início do processo) e o horário registrado pela pesquisadora quando o cliente chega na área de acesso às lojas do shopping center (final do processo). Será utilizada uma planilha de medição (APÊNDICE E) para registro dos dados coletados pela pesquisadora.

O grau de incômodo do consumidor com o processo será medido na entrevista requisitando ao consumidor que indique qual das figuras da escala visual proposta por Womack e Jones (2006) (Figura 14) mais se adéqua à sua percepção em relação ao processo de estacionar o carro que acabou de executar. 
Para garantir a exatidão das medições o relógio utilizado pela pesquisadora será ajustado ao horário que constar no sistema de cancela do shopping center. Pretende-se realizar a medição em um único estabelecimento em pelo menos dois dias da semana (um dia de semana útil e outro no final de semana). Não será definido um número mínimo ou máximo de consumidores entrevistados (tamanho da amostra), mas sim a quantidade de tempo a ser dedicado para coleta dos dados (pretendendo-se adotar duas horas de dedicação em cada um dos dias de medição).

A quantidade de consumidores entrevistados não será determinada, pois um dos critérios que se pretende avaliar nesta pesquisa é o grau de adesão do consumidor à pesquisa, ou seja, quantos clientes se dispõem a responder à enquete no tempo que a pesquisadora dedicar à coleta de dados.

Diferentemente do que ocorre no processo com interação remota, no qual a coleta de dados ocorre remotamente, sem interação direta do pesquisador ou da empresa com o consumidor, no processo com interação presencial haverá contato direto entre entrevistador e consumidores entrevistados para coleta dos dados.

$\mathrm{Na}$ coleta de dados presencial considera-se que haverá maior investimento de tempo da pesquisadora para coleta de dados, pois os dados não deverão ser preenchidos em uma planilha ou formulário pelos próprios consumidores, mas terão de ser registrados pela pesquisadora durante as entrevistas com eles. Por outro lado, o esforço do consumidor será menor, pois terá somente que responder verbalmente as perguntas sem ter que compreender e manipular qualquer planilha ou ler e preencher formulário impresso. Além disso, na entrevista presencial será possível captar a satisfação ou incômodo do consumidor em relação ao processo por ele executado, obtendo-se maior riqueza de dados neste sentido.

Este estudo encerra, portanto, uma pesquisa exploratória, uma vez que se pretende ampliar o conhecimento sobre uma prática - aplicação da ferramenta Mapa de Consumo - cuja aplicabilidade no contexto real das organizações de serviço ainda é desconhecida.

Tal como resume a Tabela 6, este trabalho utilizará três métodos de pesquisa para avaliar a aplicabilidade da ferramenta Mapa de Consumo para os serviços do tipo "faça você mesmo" com interação remota e com interação presencial. No serviço 
objeto de estudo com interação remota a pesquisa será desenvolvida por meio de duas vertentes, uma que adota a empresa como fonte de dados, utilizando o método estudo de caso, e a outra vertente que tem o consumidor como fonte de dados, apoiando-se no método experimento.

Tabela 6 - Métodos de pesquisa empregados

\begin{tabular}{lccc}
\hline \multicolumn{1}{c}{ Tipo de serviço } & \multicolumn{2}{c}{$\begin{array}{c}\text { Fonte de dados } \\
\text { Empresa }\end{array}$} & $\begin{array}{c}\text { Serviço objeto de } \\
\text { estudo }\end{array}$ \\
\hline $\begin{array}{l}\text { "Faça você mesmo" com } \\
\text { interação remota }\end{array}$ & Experimento & $\begin{array}{c}\text { Estudo de caso } \\
\text { único: Empresa } \\
\text { Cupom }\end{array}$ & Compra coletiva \\
\hline $\begin{array}{l}\text { "Faça você mesmo" com } \\
\text { interação presencial }\end{array}$ & Enquete & - & $\begin{array}{c}\text { Estacionar em um } \\
\text { shopping center }\end{array}$ \\
\hline
\end{tabular}

Para o serviço com interação presencial foi adotada uma vertente única na qual a coleta de dados é realizada junto ao consumidor por meio de uma enquete. No estudo do processo de estacionar o carro em um shopping center não vislumbrou-se a possibilidade de coleta de dados junto a organização uma vez que não foi possível identificar provedores deste tipo de serviço que meçam o tempo gasto pelo consumidor para estacionar o veículo. Entretanto, entende-se que a coleta de dados por meio da empresa no mapeamento de serviços "faça você mesmo" com interação remota possa se mostrar viável para outros tipos de serviço em que a empresa registre dados referentes às tarefas executadas pelo consumidor. 


\section{DESCRIÇÃO E ANÁLISE DO PROCESSO COM INTERAÇÃO REMOTA}

Este capítulo é dedicado à exploração do processo de construção do Mapa de Consumo para os processos do tipo "faça você mesmo" com interação remota focando o caso de um processo real de compra coletiva pela internet.

A coleta de dados para construção do Mapa de Consumo é aqui considerada pela adoção de dois métodos de pesquisa, o estudo de caso e o experimento, tendo a empresa provedora do serviço e os consumidores, respectivamente, como fonte de dados.

"Compra coletiva" é a denominação atribuída a um serviço eletrônico em que um site divulga e vende serviços de várias empresas a preços promocionais para um número mínimo de clientes que aderirem à oferta. Criado nos Estados Unidos em 2008 pelo site Groupon e introduzido no Brasil em 2010 tendo o site Peixe Urbano como pioneiro, esta forma de serviço rapidamente conquistou uma grande quantidade de clientes o que motivou a criação de diversos outros sites de compra coletiva. No Brasil já existem mais de mil empresas atuando neste mercado (GAVIOLI, 2011).

Uma oferta de compras coletiva caracteriza-se por um alto volume de clientes que compram o mesmo produto ou serviço por um preço que em geral é de $50 \%$ a $90 \%$ menor do que seria pago diretamente na loja. O desconto é divulgado por um site de compra coletiva durante um determinado período, geralmente 24 horas. Neste período, um número mínimo de consumidores deve aderir à oferta para que a mesma se torne válida. Se a meta mínima de clientes for atingida, todos os compradores recebem por e-mail o cupom de desconto referente à compra desejada (COMPRA COLETIVA, 2011).

"A compra coletiva é a mais nova estratégia de promoção no e-commerce." (COMPRA COLETIVA, 2011). Utilizada principalmente pelas médias e pequenas empresas para divulgarem seus produtos e serviços esta forma de negócio foca, principalmente, na venda de serviços com descontos (CABRAL, 2011). 
Além dos baixos preços dos produtos e serviços ofertados, outro fator que contribui para o sucesso nesta modalidade de negócio é a disponibilidade da oferta. A promoção usualmente permanece no site de compra coletiva por 24 horas e estabelece um número mínimo e máximo de compradores. O consumidor, portanto, não tem muito tempo para decidir entre comprar ou não a oferta, e muitas vezes, levado por um impulso ou pelo fato da oferta estar disponível por um tempo curto de algumas horas, acaba por efetivar a compra para não perder uma oportunidade (ARAUJO, 2010).

Este tipo de serviço utiliza o meio eletrônico para contato com o consumidor o qual, via internet, acessa os sites de compra coletiva, avalia as opções de promoção, verifica as que o interessam e realiza as tarefas, inicialmente, cadastrando-se no site, e em seguida, escolhendo os detalhes da compra e executando o pagamento. Após a compra, o consumidor acessa sua conta de e-mail e localiza o cupom que Ihe foi enviado pelo site, o qual deve ser impresso e apresentado ao estabelecimento onde o bem ou serviço em promoção deve ser adquirido. Trata-se, portanto de um exemplo de serviço cujo processo de serviço, sobretudo nas etapas iniciais, baseia-se em interações remotas do consumidor com um site na internet.

Para pesquisar o processo de construção do Mapa de Consumo e medição das tarefas desempenhadas por consumidores que buscam este tipo de serviço diferentes métodos de coleta de dados foram adotados, a saber:

(a) observação ativa do processo objeto de estudo;

(b) estudo de caso com uma empresa provedora do serviço objeto de estudo;

(c) experimento com consumidores do serviço objeto de estudo.

\subsection{MAPEAMENTO DO PROCESSO}

O primeiro passo para a construção do Mapa de Consumo do processo objeto de estudo é entender como as tarefas executadas pelos consumidores podem ser 
mapeadas (Q2). Neste sentido, os seguintes passos foram seguidos no estudo do processo de compra coletiva:

- colocar-se na posição do consumidor do processo objeto de estudo desempenhando as atividades que Ihe são atribuídas;

- esquematizar uma versão inicial do fluxo do processo identificando as tarefas desempenhadas pelo consumidor;

- validar o fluxo obtido:

- junto a empresa provedora do serviço por meio do método de estudo de caso;

- junto aos consumidores por meio das observações capturadas no método de experimento;

- executar as alterações capturadas nas validações e obter a versão final do fluxo das tarefas executadas pelos consumidores;

A construção do Mapa de Consumo iniciou com a observação ativa do processo de serviço focado pela pesquisadora, a fim de vivenciá-lo segundo a ótica do consumidor e, inclusive, validar se o caso prático escolhido era compatível com o escopo desta pesquisa.

Por meio da visita a alguns sites de compra coletiva, foi possível compreender o fluxo básico do processo do consumidor. Apesar de existirem muitos sites que oferecem a compra coletiva, seus processos apresentam características bastante semelhantes o que faz com que o fluxo de tarefas estabelecido para o consumo não apresente grandes variações entre um site e outro. Em processos deste tipo, os encontros de serviço ocorrem em dois momentos. Primeiramente, ocorre um encontro entre o consumidor e o site da empresa que divulga as promoções que pode culminar com a efetivação da compra. Posteriormente, ocorre o encontro entre o consumidor e a empresa provedora da oferta adquirida, quando o consumidor dela irá usufruir. O serviço, portanto, se inicia com o acesso do consumidor ao site de compra coletiva ou ao receber um e-mail divulgando uma oferta que the interessa e é finalizado quando o consumidor usufrui do produto ou serviço adquirido junto à empresa provedora. 
Na Figura 23 apresenta-se o fluxo do serviço de compra coletiva na visão do consumidor.

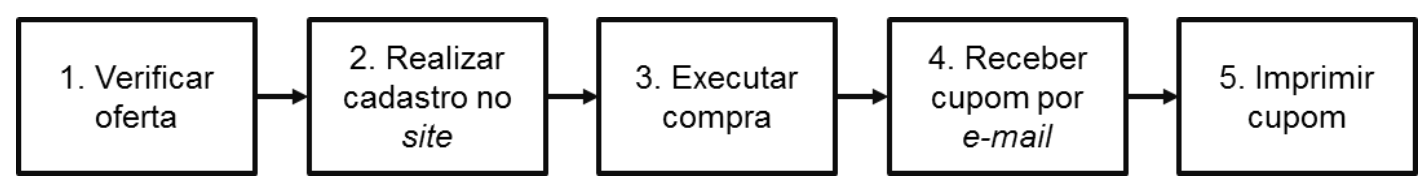

Figura 23 - Fluxo do processo de compra coletiva na visão do consumidor

Como este trabalho se restringe ao estudo da interação remota entre o consumidor e o site de compra coletiva, não irá explorar a tarefa de "utilizar a oferta", visualizada na Figura 23. Vale lembrar que um objetivo do presente trabalho é entender o papel e a experiência do consumidor enquanto agente executor de tarefas em processos de consumo de serviços do tipo "faça você mesmo" com interação remota.

As tarefas "verificar oferta", "realizar cadastro no site", "executar compra", "receber cupom por e-mail" e "imprimir cupom" são executadas pelo consumidor utilizando recursos próprios, com mínima ou nenhuma interferência da empresa provedora do serviço. A execução destas tarefas ocorre à distância, via internet, sem qualquer customização, caracterizando-se como um serviço "Faça você mesmo" com interação remota.

As tarefas elementares realizadas pelo consumidor desde a tarefa de "verificar oferta" até a de "imprimir o cupom" podem ser visualizadas no mapa da Figura 24.
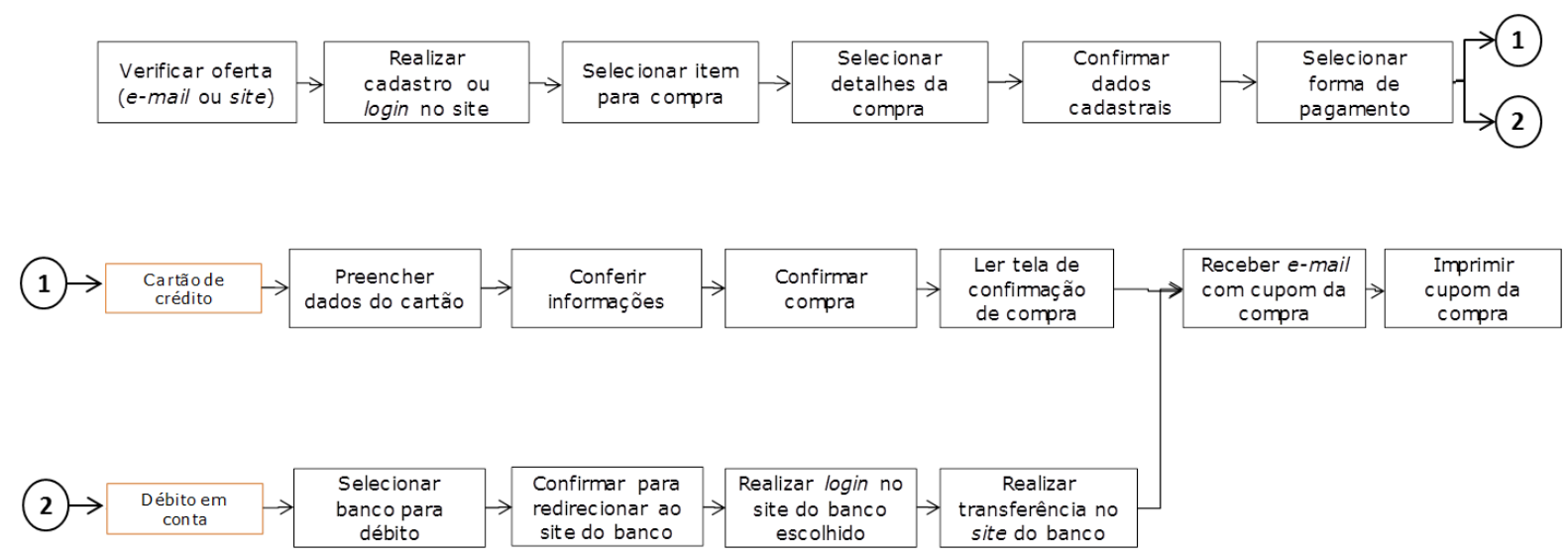

Figura 24 - Mapa detalhado do processo das tarefas executadas pelo consumidor no processo de compra coletiva 
Este mapa indica as tarefas de responsabilidade do consumidor para aquisição do serviço em um site de compra coletiva. Pelo fato do processo ser padronizado, não se observam muitas variações entre o processo do consumidor de um site de compra coletiva e o de outros ou na forma de execução das tarefas que estes sites delegam ao consumidor.

A observação ativa do processo, além de possibilitar a construção do fluxo básico do processo, permitiu à pesquisadora coletar informações que serviram de insumo para estabelecer as questões a serem exploradas nas entrevistas com empresas prestadoras deste tipo de serviço durante a realização do estudo de caso. A observação do processo mostrou-se, ainda, necessária para definir o procedimento de medição e registro de dados a ser aplicado no experimento a ser realizado junto aos consumidores deste tipo de serviço.

Desta forma, a observação e compreensão inicial do serviço objeto de estudo possibilitaram à pesquisadora atuar de forma mais assertiva durante a entrevista com a empresa e durante o experimento com os consumidores.

\subsection{MEDIÇÃO DAS TAREFAS EXECUTADAS PELO CONSUMIDOR}

A medição do esforço do consumidor na realização do processo do consumidor foi executada por meio de dois métodos de pesquisa: estudo de caso e experimento.

Conforme explicitado na seção 1.2, o esforço do consumidor, para fins desta pesquisa, será expresso em tempo gasto por ele para execução do processo.

\subsubsection{Estudo de Caso}

A realização de um estudo de caso teve como propósito explorar como uma empresa provedora de serviços poderia tentar medir as tarefas executadas pelos 
consumidores e construir Mapas de Consumo a fim de visualizar a participação dos consumidores em seus processos de serviço com base em dados que estivessem ao seu alcance ou até disponíveis.

A empresa estudada, Cupom ${ }^{6}$, possui uma estrutura familiar e iniciou suas operações em fevereiro de 2011, após a idealização da empresa e a realização de pesquisas de mercado conduzidas pelos proprietários que duraram em torno de seis meses.

As pesquisas de mercado para a estruturação do site ocorreram por meio de observações de outros sites, execução de compras nos sites de compra coletiva préexistentes, pesquisa com amigos que são consumidores deste tipo de serviço e estudos de mercado. Os proprietários se basearam nos principais tipos de ofertas existentes nos sites concorrentes para escolher as promoções que seriam expostas no site. Ademais, para desenvolverem um processo de compra fácil, rápido e seguro, conforme menciona o sócio proprietário da empresa: "direcionamos a nossa equipe comercial em busca das ofertas que mais vendiam" (BRASIL, 2011).

Além de considerar a experiência da concorrência, a empresa procurou inovar neste mercado, introduzindo alguns serviços diferenciados para seus clientes, tais como:

a. Possibilidade de executar a compra da oferta e imprimir o cupom em seguida, sem ter que aguardar dias para recebê-lo por e-mail;

b. Versão mobile, na qual não é necessário imprimir o cupom podendo carregar o código da oferta adquirida via um telefone celular;

c. As compras realizadas em conjunto com amigos oferecem descontos ainda maiores, estimulando a divulgação do site e fazendo com que os clientes aproveitem as ofertas com seus amigos;

d. Sorteio de ofertas gratuitas para os clientes.

A empresa acredita que o mercado de compra coletiva é algo que revolucionou os hábitos de consumo e que tem mudado a vida das pessoas. Para controlar os

6 Nome fantasia atribuído à empresa de compra coletiva abordada neste estudo a fim de se manter sigilo da sua identidade. 
acessos ao site e o processo de compra a empresa optou por utilizar a ferramenta Google Analytics, mediante a qual pode acompanhar as visitas ao seu site desde o primeiro acesso do consumidor até a finalização da compra ou a desistência. Dessa forma, a empresa consegue coletar dados para analisar e implantar pontos de melhoria para tornar a experiência de compra cada vez mais fácil, rápida e segura. As dúvidas mais frequentes dos clientes são inseridas no site a fim de compartilhar com os demais clientes as formas de como proceder em diversas situações que podem ocorrer durante a compra.

Os principais dados captados pela empresa através do Google Analytics podem ser observados na Figura 25, tais como: número de visitas ao site, número de visitantes únicos, volume de visualização de páginas, média de visualização de página por visitante, tempo do visitante no site, taxa de rejeição (percentual de visitantes que acessam o site e não executam a compra) e taxa de novas visitas. Os valores visualizados no painel de gestão do Google Analytics correspondem às médias dos dados coletados pelo site desde a adoção desta ferramenta pela empresa.

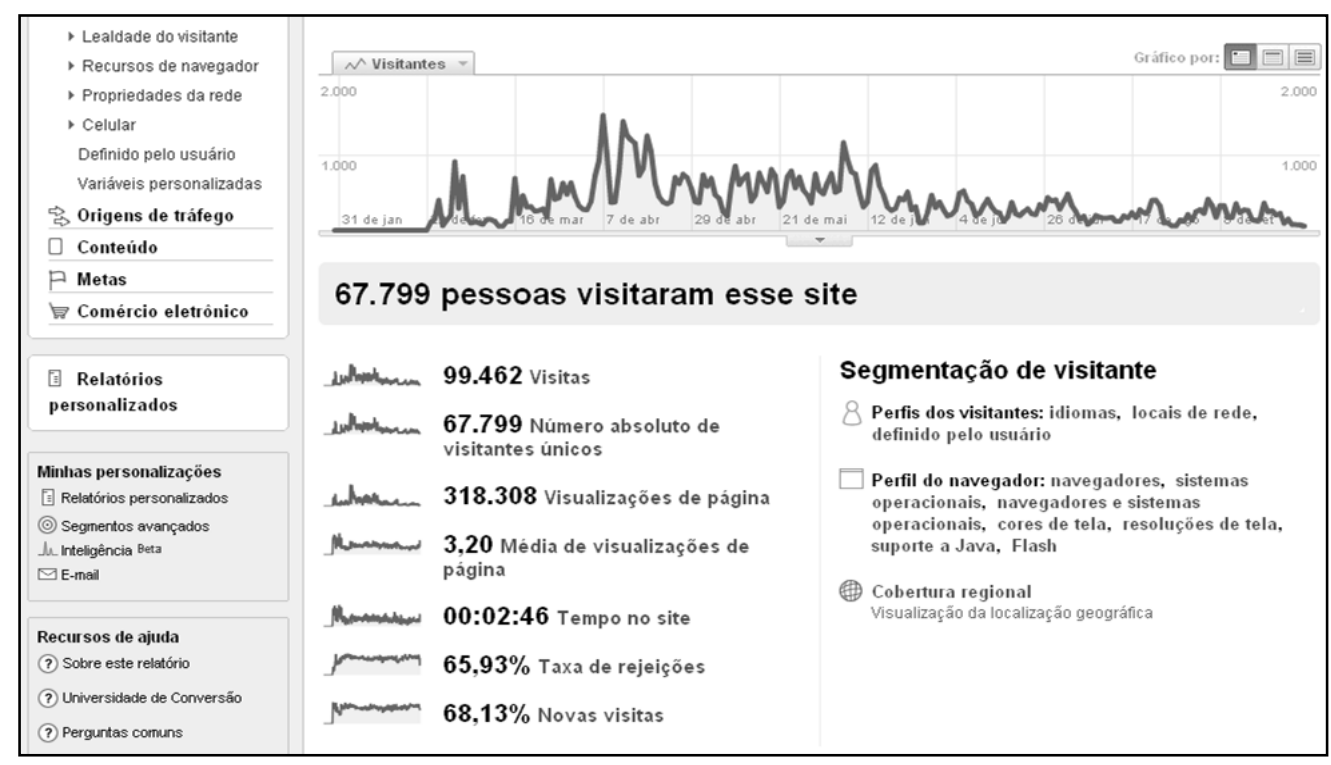

Figura 25 - Painel de gestão Google Analytics da empresa Cupom Fonte: Disponibilizado pela empresa Cupom 
Dos dados disponibilizados pela empresa, o tempo de permanência do visitante no site é um dado que se mostrou extremamente relevante para esta pesquisa, pois está relacionado ao esforço realizado pelo consumidor durante a visita ao site. $\mathrm{O}$ período considerado para a extração dos indicadores foi de 23 de fevereiro de 2011 a 28 de setembro de 2011 no qual foi possível coletar 218 medições do tempo médio diário de execução do processo pelos consumidores.

Alguns dos relatórios que podem ser extraídos do Google Analytics são apresentados no Gráfico 3 e fornecem dados como a média diária, semanal e mensal do tempo de permanência dos consumidores no site. A linha inferior (cinza escura) representa a média de tempo gasto no site pelos consumidores que não finalizaram a compra. A linha superior (cinza clara) indica a média de tempo gasto pelos consumidores que finalizaram a compra.

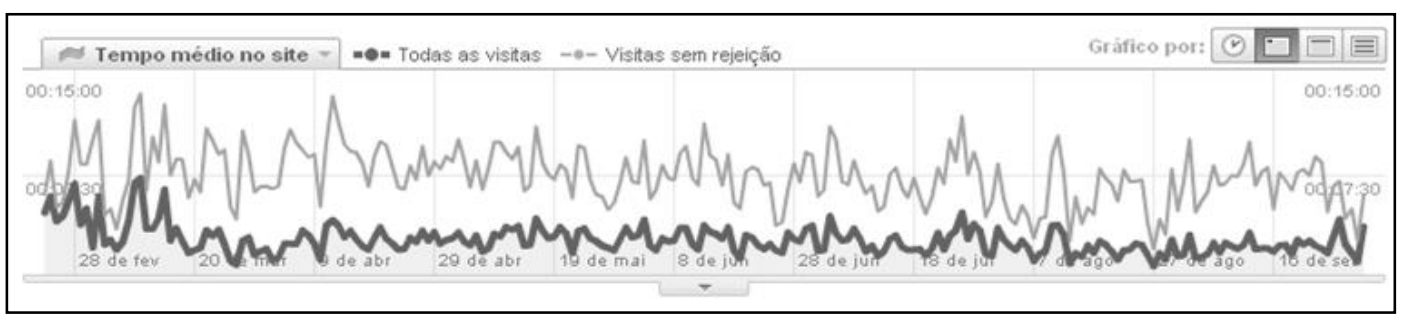

(a) Média por dia

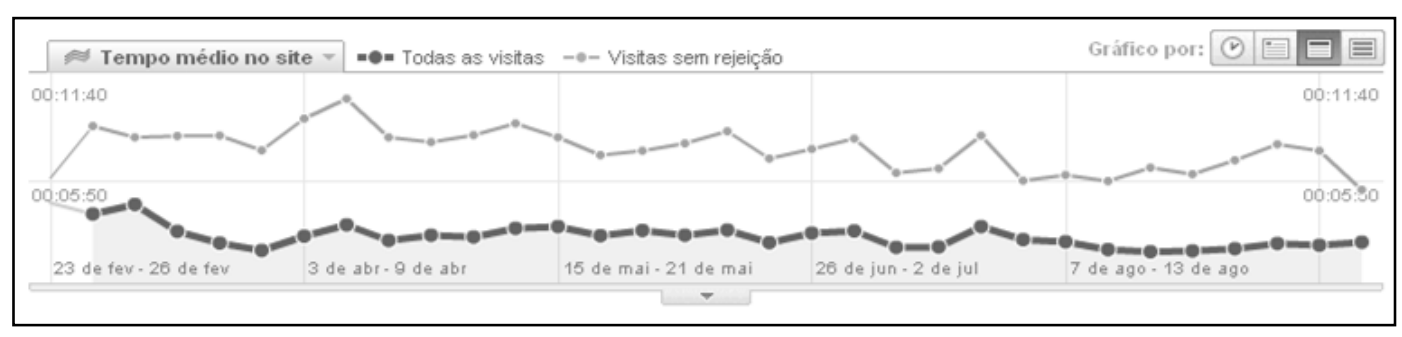

(b) Média por semana

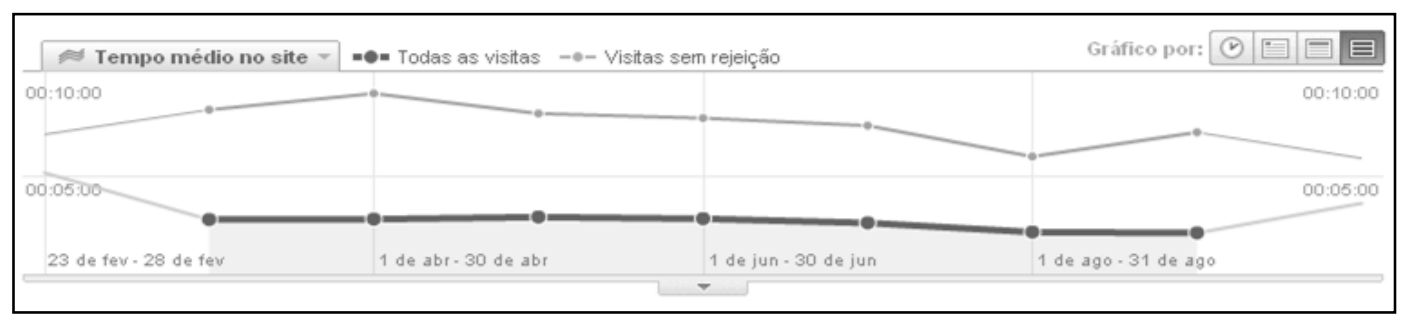

(c) Média por mês

Gráfico 3 - Tempo médio do visitante no site por dia, por semana e por mês Fonte: Disponibilizado pela empresa Cupom 
Analisando os tempos médios diários de permanência dos consumidores no site, verifica-se que no início da operação do site os tempos de permanência dos consumidores eram mais elevados quando se considera a base dos consumidores que não finalizaram a compra, conforme se visualiza no Gráfico 4. Isso indica que houve instabilidade do processo na fase inicial de instalação da operação. Porém, com o passar do tempo e estabilização do site a variação do tempo gasto pelos consumidores passou a ser melhor controlado, e se acomodou numa faixa de variação com menor amplitude em torno de um valor central menor que o observado na fase inicial.

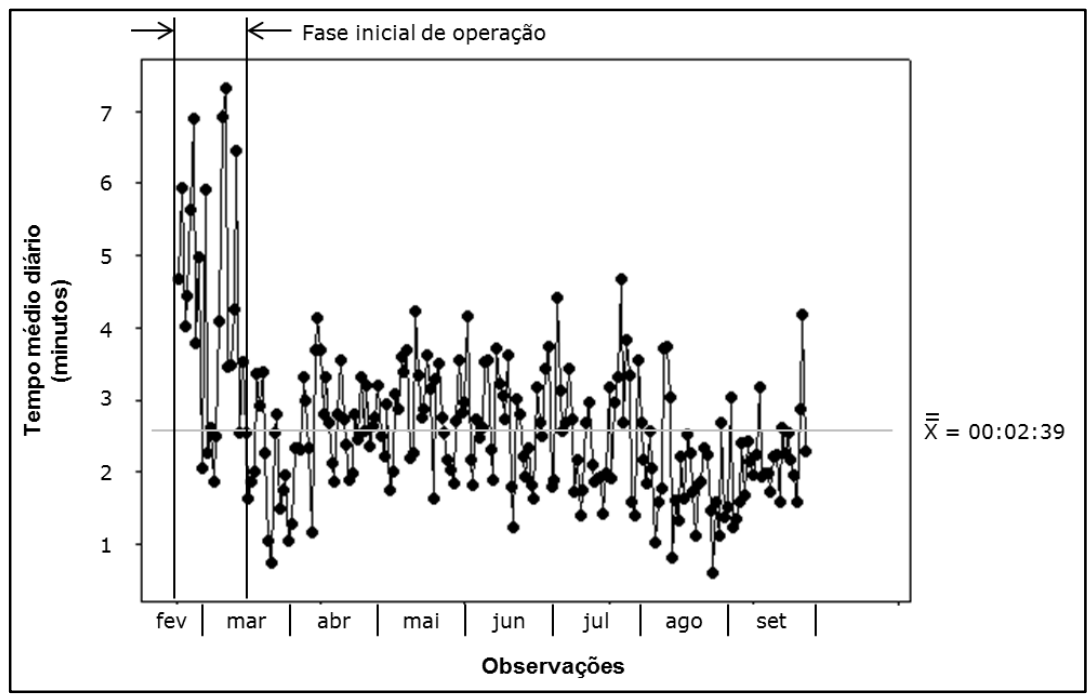

Gráfico 4 - Gráfico linear dos tempos médios diários de permanência no site dos visitantes que não finalizaram a compra

Fonte: Dados da empresa Cupom

Analisando o gráfico linear do tempo médio diário gasto pelos consumidores que finalizaram a compra pelo site apresentado no Gráfico 5 verifica-se que os tempos médios diários de permanência são significativamente maiores quando comparados ao tempo médio diário dedicado pelos consumidores que não finalizaram a compra exibido no Gráfico 4. O Gráfico 5 também indica que no período considerado a média do tempo gasto pelos consumidores para realizarem a compra foi de 7 minutos e 31 segundos. 


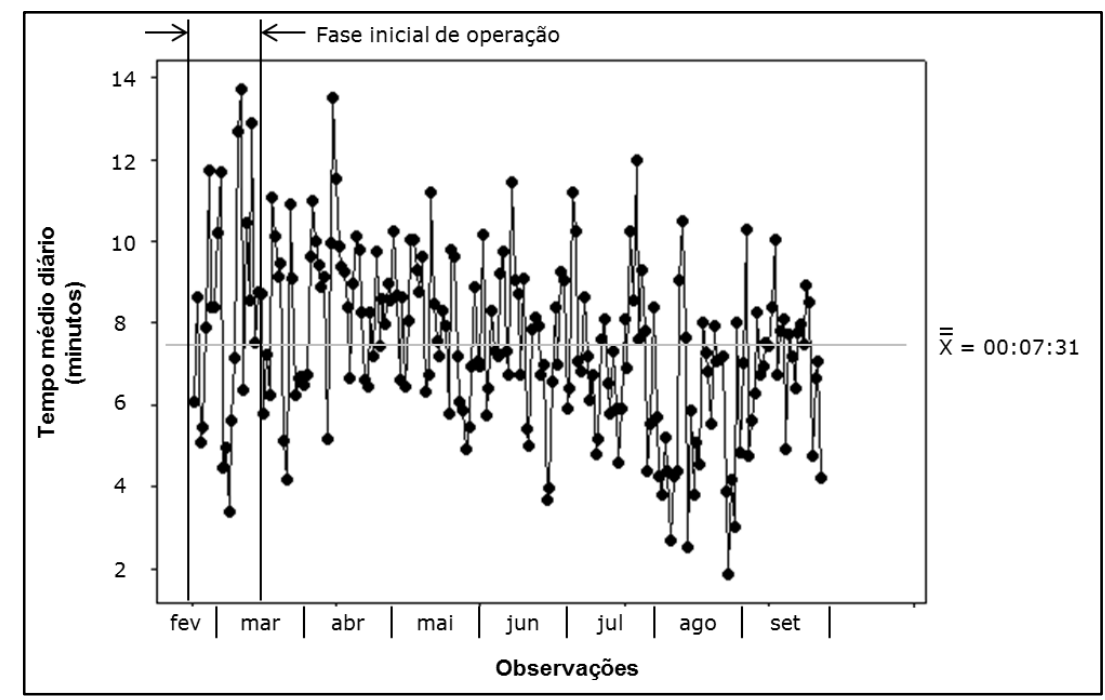

Gráfico 5 - Gráfico linear dos tempos médios diários de permanência no site dos visitantes que finalizaram a compra

Fonte: Dados da empresa Cupom

As distribuições dos tempos de permanência dos visitantes que não finalizaram a compra (que rejeitaram) e que finalizaram a compra podem ser também analisadas nos histogramas exibidos, respectivamente, pelo Gráfico 6 e pelo Gráfico 7.

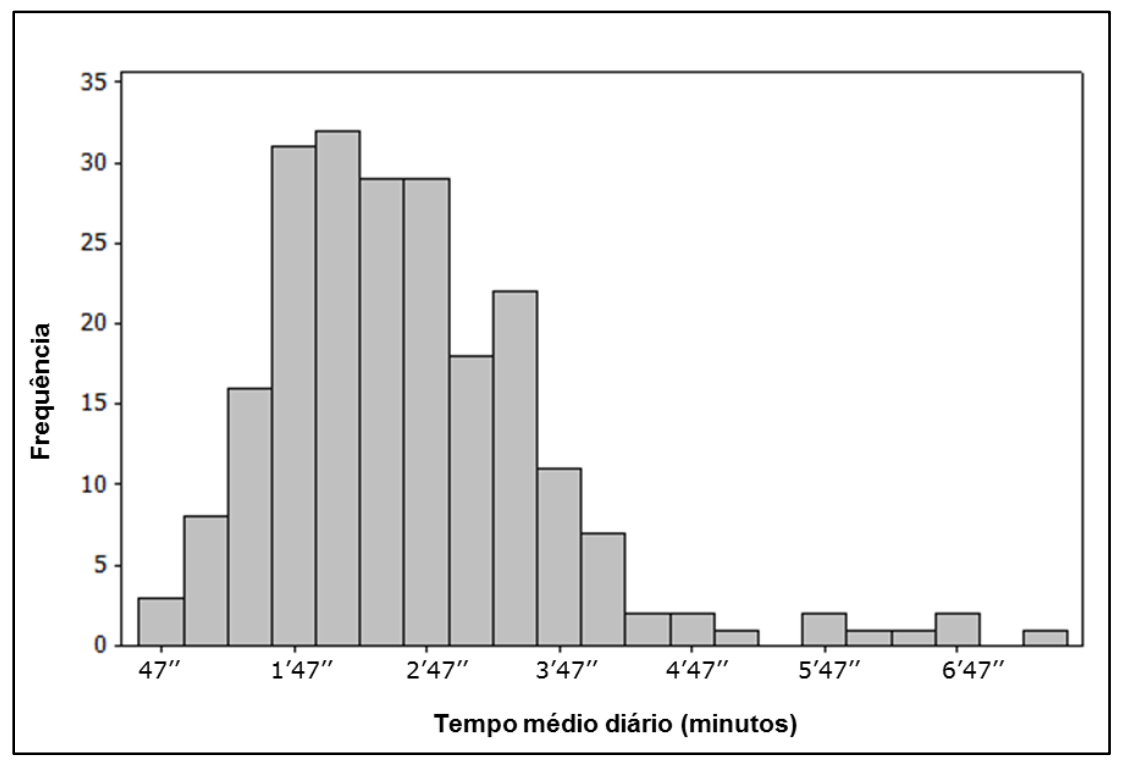

Gráfico 6 - Histograma dos tempos médios diários de permanência no site dos visitantes que não finalizaram a compra

Fonte: Dados da empresa Cupom 


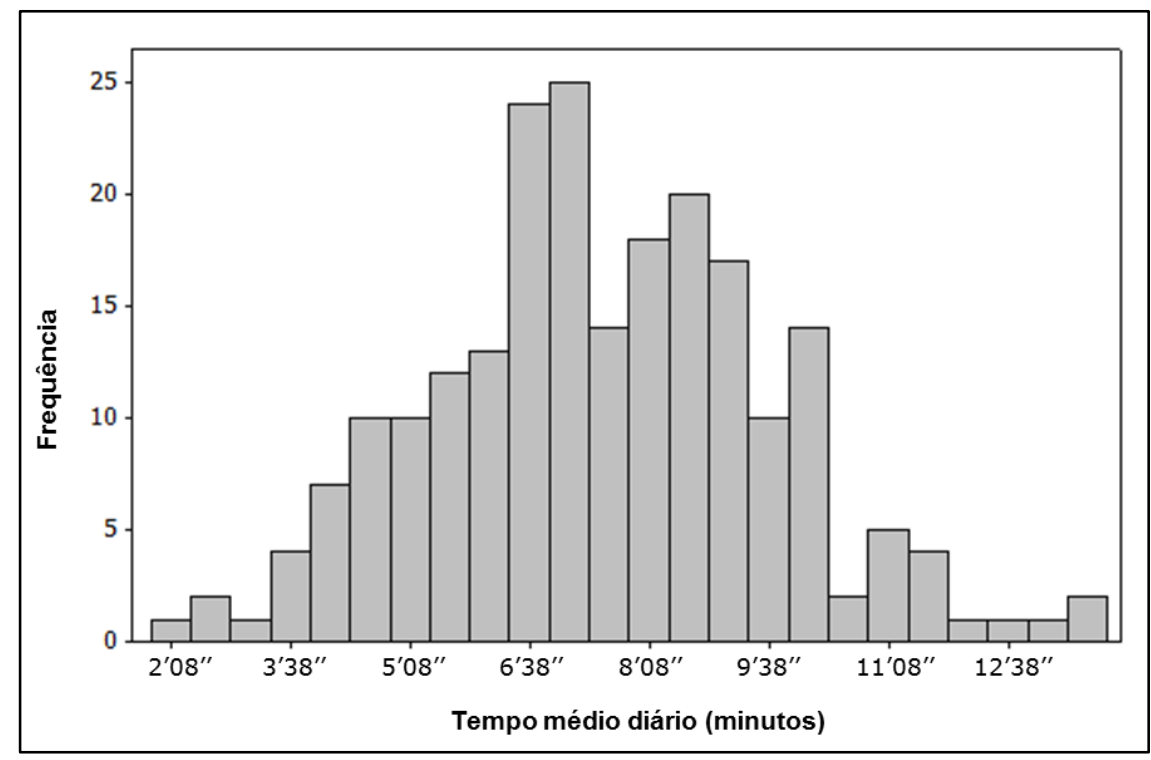

Gráfico 7 - Histograma dos tempos médios diários de permanência no site dos visitantes que finalizaram a compra

Fonte: Dados da empresa Cupom

Os dados coletados permitem ainda verificar, conforme resumo da Tabela 7, o máximo e o mínimo entre os dados de tempo médio diário de permanência dos consumidores no site bem como os valores dos parâmetros referentes à sua posição central (média, mediana).

Tabela 7 - Parâmetros das distribuições do tempo médio diário de permanência dos consumidores no site

\begin{tabular}{lcc}
\hline & $\begin{array}{c}\text { Visitantes que não } \\
\text { finalizaram a compra }\end{array}$ & $\begin{array}{c}\text { Visitantes que } \\
\text { finalizaram a compra }\end{array}$ \\
\hline Máximo & $00: 07: 19$ & $00: 13: 43$ \\
Média & $00: 02: 39$ & $00: 07: 31$ \\
Mediana & $00: 02: 30$ & $00: 07: 24$ \\
Mínimo & $00: 00: 37$ & $00: 01: 53$ \\
\hline
\end{tabular}

Fonte: Dados disponibilizados pela empresa - Relatórios Google Analytics

Outro indicador controlado pela empresa é o percentual de rejeições, ou seja, a parcela de consumidores que acessam o site e não efetuam a compra. Como se pode observar no Gráfico 8, a média de rejeições no período considerado foi de $65,9 \%$. Isso significa que $34,1 \%$ dos visitantes que acessaram o site neste período 
realizaram a compra adquirindo a promoção ofertada no site de compra coletiva da empresa Cupom e executando todas as tarefas necessárias para concretizar esta etapa do processo do consumidor.

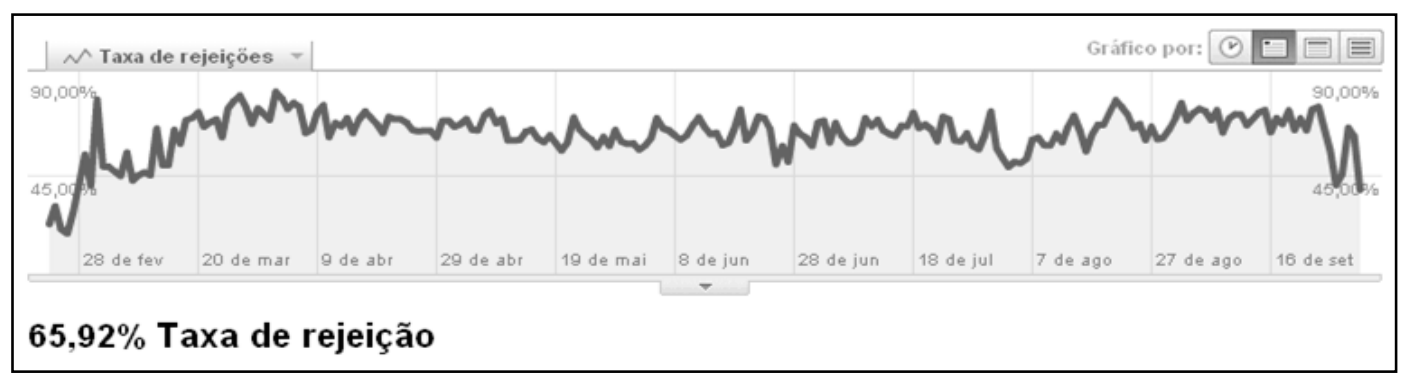

Gráfico 8 - Taxa de rejeição do site (parcela dos consumidores que visitaram o site e não finalizaram a compra)

Fonte: Disponibilizado pela empresa Cupom

Os dados coletados por meio do estudo de caso da empresa Cupom acrescentar detalhes ao fluxo esquematizado na Figura 23 e gerar uma visão parcial do Mapa de Consumo referente ao processo de serviço objeto de estudo. O Mapa de Consumo que pode ser assim obtido é apresentado na Figura 26 observando as características do modelo de representação proposto por Womack e Jones (2006).

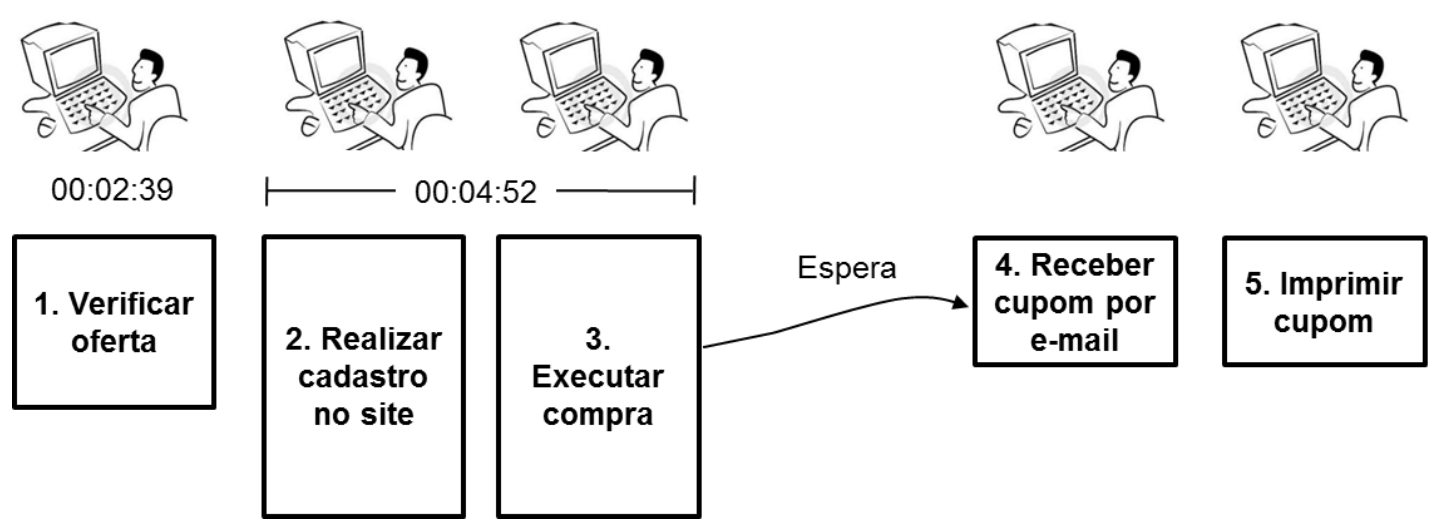

Figura 26 - Mapa de Consumo do processo de compra coletiva através dos dados fornecidos pela empresa provedora do serviço capturado via Google Analytics

Este mapa inclui estimativas de tempo para a execução das tarefas "verificar oferta", "realizar cadastro no site" e "executar compra". Para isso, admitiu-se que o tempo da primeira tarefa é aproximadamente o mesmo que o tempo que um visitante acessa o site mas não finaliza a compra, pois equivale ao tempo em que fica verificando 
ofertas até decidir não comprar. Com base nos dados da Tabela 7 , o tempo médio da primeira tarefa foi estimado em 00:02:39.

Quanto aos tempos para execução da segunda e terceira tarefas, constatou-se que dos dados fornecidos pelo Google Analytics não seria possível estimá-los, separadamente. Contudo, notou-se que seria possível estimar a duração do tempo total para execução destas duas tarefas em seguida, admitindo que este tempo seria aproximadamente a diferença entre o tempo que consumidores que visitam o site e finalizam a compra e o tempo que os visitantes que acessam este site mas não finalizam a compra. Assim, com base nos dados da Tabela 7, pode-se estimar 0 tempo médio para execução dessas duas tarefas em série, subtraindo 00:02:39 de 00:07:31, o que resulta no tempo médio de 00:04:52.

Neste caso, o Mapa de Consumo não pode ser construído de forma completa, pois a empresa possui medidas de somente uma parte do processo objeto de estudo. Algumas das tarefas desempenhadas pelo consumidor como "Receber cupom por $e$ mail" e "Imprimir cupom" não são monitorados pelo site do provedor do serviço o que impossibilita a coleta do tempo dedicado a estas tarefas por meio da ferramenta do Google Analytics.

Os dados atrelados à satisfação ou incômodo do consumidor em realizar tarefas do processo e o percentual de valor e desperdício de cada tarefa não puderam ser coletados junto à empresa focada no estudo de caso. Como o processo ocorre de forma remota, o provedor não consegue observar as ações e percepções do consumidor diante do site. Para contornar esta limitação, o provedor poderia requisitar ao consumidor, no final do processo de compra, que pontuasse sua satisfação quanto à tarefas executadas ou indicasse sugestões de melhorias para redução do tempo gasto em alguma parte do processo.

No caso da empresa Cupom a medição da satisfação ou incômodo do consumidor somente é possível através de perguntas, sugestões ou reclamações que a empresa venha a receber do cliente através do canal Fale Conosco disponibilizado no site. Esta fonte de dados, entretanto, não fornece informações estruturadas relacionadas ao grau de satisfação do consumidor com o processo e, portanto, não pode ser utilizada na construção do Mapa de Consumo. 
Por meio do método de estudo de caso verificou-se que a empresa prestadora do serviço, quando interessada em analisar as tarefas desempenhadas pelo consumidor, pode utilizar ferramentas computadorizadas para certas medições do processo. Isto é possível em processos categorizados como "faça você mesmo" com interação remota, pois, para a execução de uma parte das tarefas que the são delegadas, o consumidor utiliza sistemas computadorizados da empresa prestadora do serviço que viabilizam o registro de dados referentes à participação dos consumidores.

O exemplo de Mapa de Consumo da Figura 26, construído com os dados que puderam ser coletados junto à empresa Cupom atende, ainda que de forma parcial, aos seguintes critérios definidos na introdução do Capítulo 3.

(a) fluxo do processo detalhando as tarefas desempenhadas pelo consumidor;

(b) forma de interação entre consumidor e empresa e

(c) tempo gasto pelo consumidor para execução das tarefas.

Por outro lado, o estudo deste caso evidenciou que somente com o apoio de sistemas de monitoramento computadorizados, não é possível construir um Mapa de Consumo completo para o processo de serviço objeto de estudo.

\subsubsection{Experimento}

A realização de um experimento foi um outro método de pesquisa adotado para apoiar a construção de um Mapa de Consumo recorrendo a consumidores do serviço objeto de estudo como fonte de dados. Nesta abordagem, procura-se contar com a colaboração dos consumidores na coleta de dados.

Uma vez que o consumidor executa o processo fora do ambiente do provedor do serviço como, por exemplo, na sua casa ou em seu trabalho, optou-se por construir e fornecer-Ihes uma planilha semiautomática, em Excel para facilitar a coleta de dados. A planilha estruturada viabilizou a coleta de dados de forma remota e 
descentralizada, possibilitando que diferentes consumidores registrassem dados referentes a sua experiência com o tipo de processo de serviço objeto de estudo.

Inicialmente, a pesquisadora acessou alguns sites de compra coletiva e executou o processo do consumidor a fim de conhecer as tarefas desempenhadas pelo consumidor e identificar quais destas precisariam ser medidas para construção do Mapa de Consumo. O levantamento realizado possibilitou identificar as variáveis a serem controladas no experimento e assim definir a forma de estruturação da a planilha de medição a ser utilizada pelos consumidores.

A planilha desenvolvida foi inicialmente testada por alguns consumidores e após revisada para torna-la mais fácil de preencher foi, posteriormente, enviada a 20 consumidores potenciais para registrarem dados sobre as tarefas executadas na aquisição de ofertas sites de compra coletiva durante um período de dois meses. Juntamente com a planilha foi-lhes enviado um manual para auxiliar na sua utilização (APÊNDICE C).

Dos consumidores abordados, $30 \%$ aderiram à solicitação de preenchimento da planilha e retornaram a planilha com os dados por eles coletados. Foi obtida uma amostra de 16 transações de compra realizadas por estes consumidores, das quais $88 \%$ puderam ser aproveitadas para a construção do Mapa de Consumo.

Na Tabela 8 apresentam-se os dados obtidos por meio deste experimento, sendo que as transações 7 e 15 foram desconsideradas. Uma das transações (7) foi descartada por apresentar inconsistência nos dados preenchidos na planilha (horário de término da compra anterior ao horário de início da compra) e a outra (15), por não fornecer dados coletados da forma prescrita nas instruções da planilha, conforme pode ser verificado na Tabela 8. 
Tabela 8 - Dados coletados através do experimento com consumidores

\begin{tabular}{|c|c|c|c|c|c|c|c|c|c|c|c|c|c|c|c|c|}
\hline \multicolumn{17}{|l|}{$\mid \stackrel{\Xi}{\circ} \cong$} \\
\hline 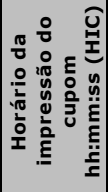 & $\begin{array}{l}\stackrel{\circ}{0} \\
\stackrel{0}{\circ} \\
\stackrel{\sim}{N}\end{array}$ & 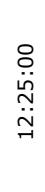 & 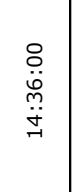 & 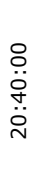 & 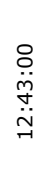 & 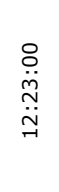 & 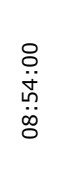 & $\begin{array}{l}\stackrel{8}{0} \\
\stackrel{-}{-1} \\
\stackrel{ت}{0}\end{array}$ & 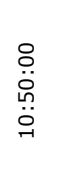 & 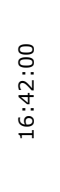 & $\begin{array}{l}\stackrel{o}{o} \\
\stackrel{0}{0} \\
\stackrel{\ddot{N}}{\sim}\end{array}$ & $\begin{array}{l}\stackrel{\circ}{\circ} \\
\stackrel{\sim}{\ddot{H}} \\
\stackrel{\circ}{\Delta}\end{array}$ & $\begin{array}{l}\stackrel{0}{0} \\
\ddot{0} \\
\ddot{\ddot{o}} \\
\ddot{0}\end{array}$ & $\begin{array}{l}\stackrel{\circ}{\circ} \\
\dot{\hat{n}} \\
\ddot{o}\end{array}$ & & $\begin{array}{l}\stackrel{\circ}{\ddot{\circ}} \\
\ddot{\circ} \\
\ddot{8}\end{array}$ \\
\hline 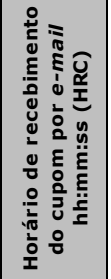 & 品 & $\begin{array}{l}\stackrel{8}{0} \\
\stackrel{0}{0} \\
\stackrel{\leftrightarrow}{0} \\
\stackrel{-}{n}\end{array}$ & 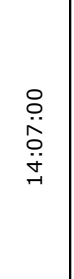 & 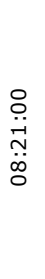 & 兽 & $\begin{array}{l}\stackrel{\circ}{\circ} \\
\stackrel{N}{N} \\
\stackrel{\infty}{\circ}\end{array}$ & $\begin{array}{l}\stackrel{8}{o} \\
\stackrel{\leftrightarrow n}{n} \\
\stackrel{\ddot{H}}{0}\end{array}$ & $\begin{array}{l}\stackrel{8}{0} \\
\stackrel{-}{-} \\
\stackrel{ت}{0}\end{array}$ & $\begin{array}{l}\stackrel{o}{o} \\
\stackrel{o}{o} \\
\stackrel{i}{i} \\
\text { N }\end{array}$ & $\begin{array}{l}\stackrel{0}{0} \\
\ddot{0} \\
\dot{0} \\
\infty \\
0\end{array}$ & $\begin{array}{l}\stackrel{\circ}{o} \\
\stackrel{\ddot{m}}{m} \\
\stackrel{m}{\sim} \\
\sim\end{array}$ & $\begin{array}{l}\stackrel{\circ}{0} \\
\ddot{\circ} \\
\stackrel{\ddot{m}}{\sim}\end{array}$ & $\begin{array}{l}\stackrel{8}{0} \\
\dot{+} \\
\dot{+} \\
\dot{\sigma}\end{array}$ & $\begin{array}{l}\stackrel{\circ}{\circ} \\
\stackrel{0}{0} \\
\ddot{0}\end{array}$ & 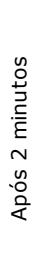 & $\begin{array}{l}\stackrel{8}{0} \\
\ddot{\circ} \\
\ddot{\circ} \\
\stackrel{0}{0}\end{array}$ \\
\hline 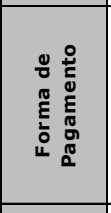 & 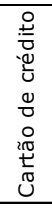 & 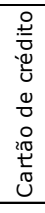 & 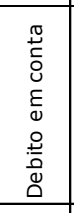 & 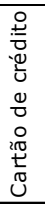 & 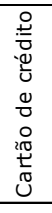 & 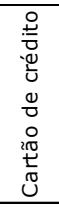 & 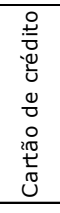 & 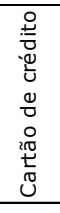 & 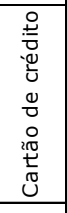 & 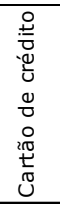 & 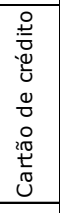 & 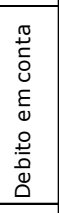 & 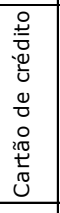 & 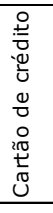 & 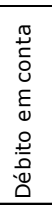 & 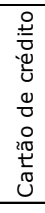 \\
\hline 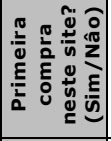 & E & $\frac{i 0}{2}$ & $\frac{20}{2}$ & $\frac{2 \pi}{2}$ & $\frac{20}{2}$ & $\frac{20}{2}$ & $\underline{E}$ & $\frac{E}{n}$ & $\underline{E}$ & $\frac{E}{n}$ & E & $\underline{E}$ & $\underline{E}$ & $\frac{E}{n}$ & $\underline{E}$ & $\frac{20}{2}$ \\
\hline 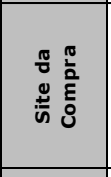 & 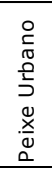 & 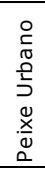 & 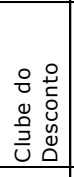 & 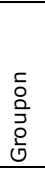 & 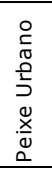 & $\begin{array}{l}5 \\
0 \\
0 \\
0 \\
0 \\
0 \\
0\end{array}$ & $\begin{array}{l}\overline{\underline{0}} \\
\stackrel{\underline{\underline{\underline{u}}}}{\overline{\bar{u}}}\end{array}$ & $\begin{array}{l}\overline{\underline{\underline{i}}} \\
\underline{\underline{\underline{\underline{u}}}} \\
\end{array}$ & 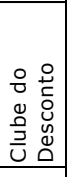 & $\begin{array}{l}5 \\
0 \\
00 \\
0 \\
0 \\
0 \\
0\end{array}$ & 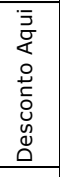 & 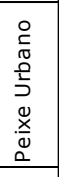 & 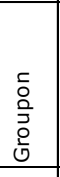 & 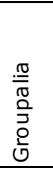 & 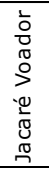 & 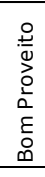 \\
\hline 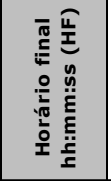 & 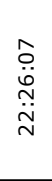 & 总 & 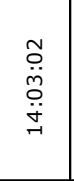 & 菊 & 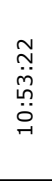 & $\begin{array}{l}\tilde{N} \\
\ddot{o} \\
\ddot{o} \\
\dot{\infty} \\
-1\end{array}$ & $\begin{array}{l}\hat{m} \\
\ddot{\infty} \\
\stackrel{0}{0} \\
\infty \\
0\end{array}$ & $\underset{\stackrel{N}{\sim}}{\stackrel{\sim}{ت}}$ & $\begin{array}{l}\stackrel{n}{\sim} \\
\stackrel{\sim}{\sim} \\
\stackrel{\sim}{\sim}\end{array}$ & 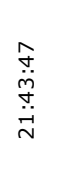 & 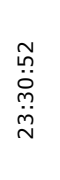 & 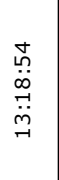 & 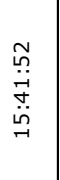 & 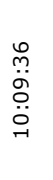 & 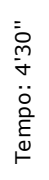 & 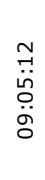 \\
\hline 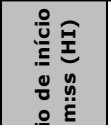 & 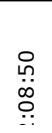 & & $\begin{array}{l}\stackrel{N}{\sim} \\
\stackrel{\hat{n}}{n}\end{array}$ & 吕 & 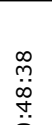 & 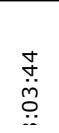 & 象 & 节 & 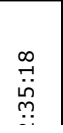 & 崵 & $\stackrel{\tilde{\dot{I}}}{\stackrel{\Perp}{*}}$ & 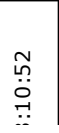 & 总 & 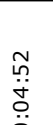 & & 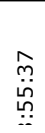 \\
\hline
\end{tabular}

Dentre os campos existentes na planilha disponibilizada para o consumidor, os campos "Horário de início" e "Horário final" contêm os dados necessários para medir o tempo gasto pelo consumidor para executar uma compra no site. Os campos "Horário de Recebimento do cupom" e "Tempo estimado para imprimir o cupom" servem para registrar outros dados necessários à construção do Mapa de Consumo referente ao processo do tipo de serviço objeto e estudo. As relações dos horários registrados na Tabela $8 \mathrm{com}$ os tempos das tarefas calculados para registro no Mapa de Consumo são explicitadas nas Equações 2, 3 e 4 definidas a seguir: 


$$
\begin{aligned}
& \text { T2 = média }(H R C-H F) \\
& \text { T3 =média }(T I C)
\end{aligned}
$$

Onde:

$\mathrm{T} 1$ = tempo gasto pelo consumidor para executar as tarefas 2 "Realizar cadastro no site" e 3 "Executar compra"

$\mathrm{T} 2$ = tempo de espera do consumidor para execução da tarefa 4 "Receber cupom por e-mail"

T3 = tempo gasto pelo consumidor para executar a tarefa 5 "Imprimir cupom"

HI = Horário de início

$\mathrm{HF}=$ Horário final

$\mathrm{HRC}=$ Horário de recebimento do cupom por e-mail

TIC = Tempo estimado para imprimir o cupom

O método do experimento possibilitou, assim, coletar outros dados para detalhar a descrição do processo e realizar análises complementares do tipo de serviço objeto de estudo.

4.2.2.1 Análise dos dados para construção do Mapa de Consumo

A aplicação do método do experimento, no esforço de obter dados que viabilizem a construção do Mapa de Consumo, gerou medições do tempo gasto pelo consumidor para "executar a compra", do tempo de espera até "receber cupom por e-mail" e, por fim, do tempo gasto pelo consumidor para "imprimir cupom" que, na Figura 23, correspondem às tarefas 2,3 e 4 do fluxo. A medição do tempo gasto na tarefa 
"verificar oferta" não foi contemplada na realização do experimento, pois nem todas as ofertas verificadas pelos consumidores são compradas. $O$ experimento contemplou, portanto, o processo de serviço, somente a partir do momento em que o consumidor decide se é de seu interesse prosseguir com a compra ou não de uma dada oferta. Uma vez tomada a decisão compra, vale salientar que a parte do processo contemplada inclui a tarefa de "realizar cadastro no site" para os consumidores que fazem a primeira compra no site.

O experimento também não buscou medir o tempo atrelado à tarefa "utilizar oferta", pois esta parte do processo está sujeita a diversas ramificações e conforme as especificidades da oferta adquirida envolve a continuidade de diferentes fluxos no processo do consumidor. Para utilizar a oferta, o consumidor tem de entrar em contato com a empresa fornecedora do serviço ou produto específico que adquiriu a um preço promocional no site de compra coletiva.

Os tempos associados à tarefa de "executar compra" (incluindo o tempo para "realizar cadastro no site" das transações de primeira compra) foram consolidados no Gráfico 9 e os tempos de espera para "receber cupom por e-mail" podem ser visualizados no Gráfico 10. Observa-se que houve alta variabilidade no tempo gasto na execução da compra, o que pode estar relacionado a fatores como usabilidade do site, complexidade do cadastro do cliente, organização e clareza das informações e até mesmo o grau de conhecimento do consumidor para executar esta tarefa. $\mathrm{O}$ tempo de espera medido para "receber cupom por e-mail" também apresentou uma alta variabilidade, fato que pode estar associado à forma como o site processa 0 envio do cupom para o e-mail do cliente. Percebe-se que alguns sites disponibilizam o cupom logo após o término da compra, enquanto outros aguardam 24 horas para enviá-lo. 


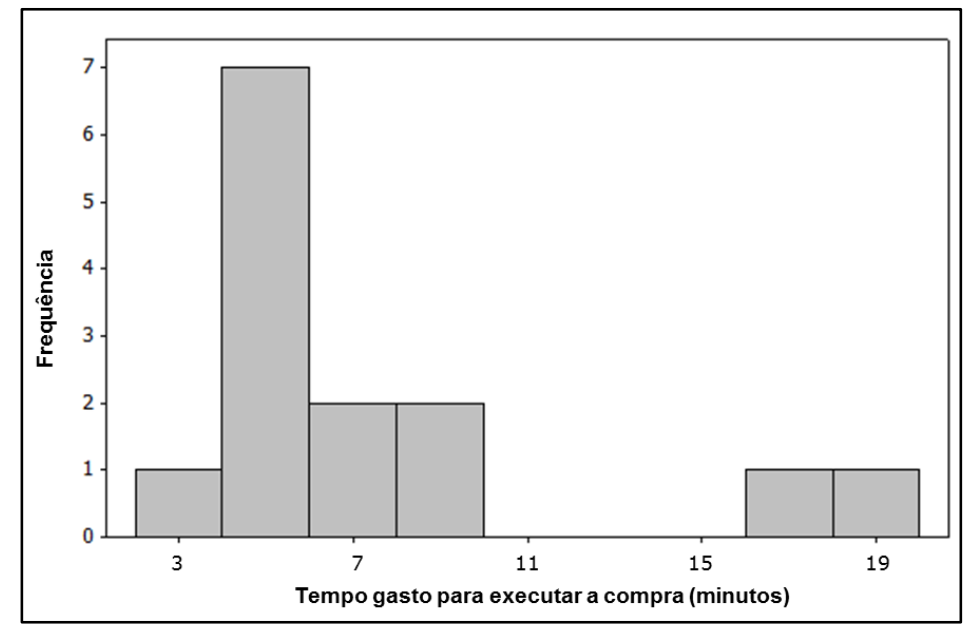

Gráfico 9 - Histograma do tempo gasto pelos consumidores para executar a compra

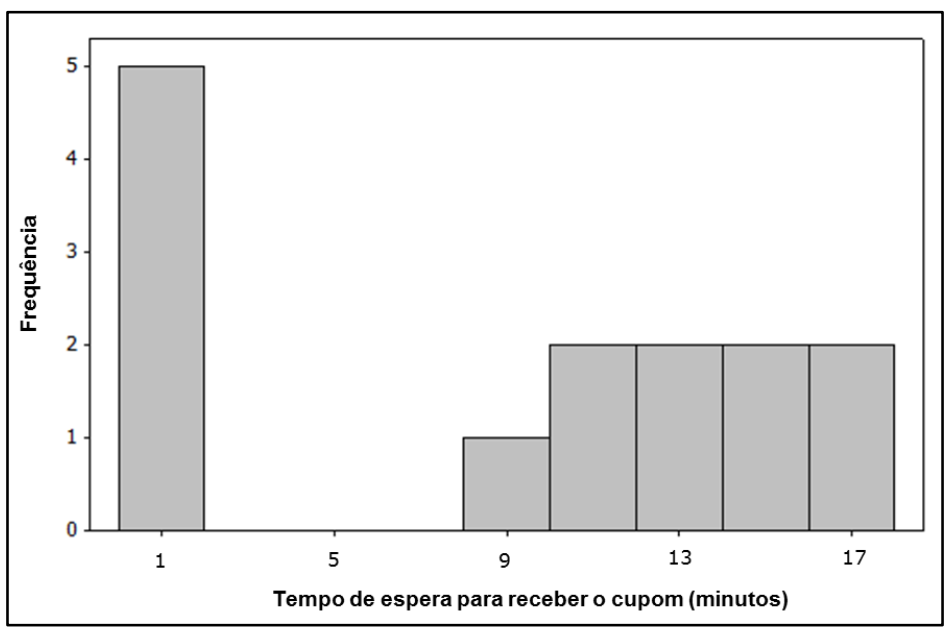

Gráfico 10 - Histograma do tempo de espera para recepção do cupom de desconto

Por fim, o experimento possibilitou obter medidas de tempo para a tarefa de “imprimir o cupom”, cuja variação, conforme apresenta o Gráfico 11, foi baixa. Vale ressaltar que apesar da ordem de grandeza do tempo desta tarefa ser bem menor em relação a de outras, para a sua realização o consumidor precisa despender mais recursos próprios. Enquanto para "executar compra" e "receber cupom por e-mail" o consumidor necessita de um computador, energia elétrica e acesso à internet, para a impressão são, adicionalmente, necessárias impressora, tinta e papel. 


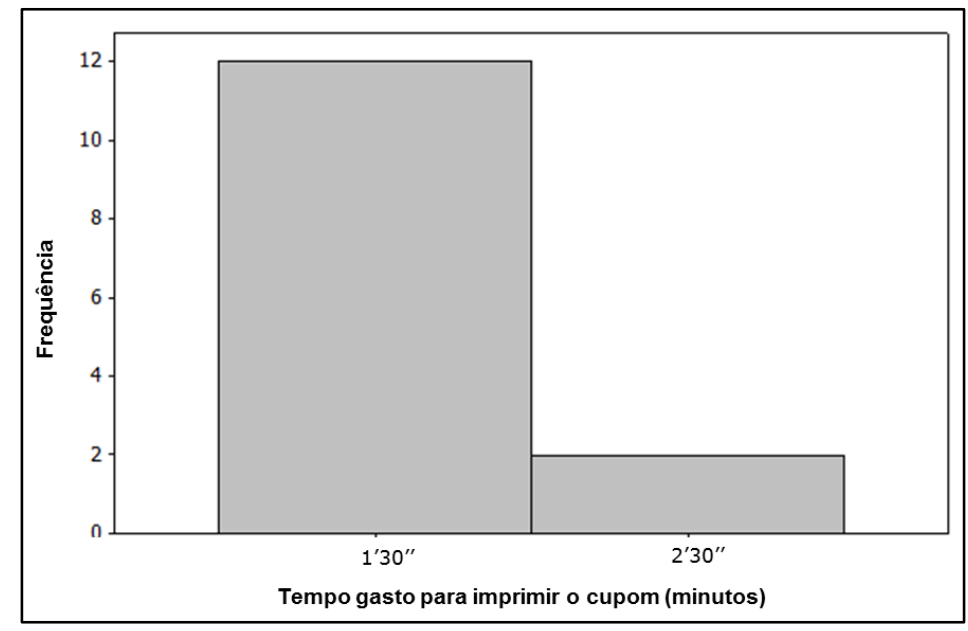

Gráfico 11 - Histograma do tempo de impressão do cupom

Os valores máximos e mínimos bem como a média e mediana dos tempos que puderam ser coletados no experimento podem ser verificados na Tabela 9.

Tabela 9 - Tempo de permanência dos consumidores no site*

\begin{tabular}{lccc}
\hline & $\begin{array}{c}\text { Tempo gasto para } \\
\text { “executar compra” }\end{array}$ & $\begin{array}{c}\text { Tempo de espera para } \\
\text { “receber cupom por e-mail” }\end{array}$ & $\begin{array}{c}\text { Tempo gasto para } \\
\text { “imprimir cupom” }\end{array}$ \\
\hline Tempo Máximo & $00: 18: 56$ & $17: 50: 09$ & $00: 02: 00$ \\
Tempo Médio & $00: 07: 36$ & $10: 15: 01$ & $00: 01: 09$ \\
Mediana & $00: 05: 39$ & $11: 27: 09$ & $00: 01: 00$ \\
Tempo Mínimo & $00: 02: 13$ & $00: 00: 48$ & $00: 01: 00$ \\
\hline
\end{tabular}

* Inclui tempo para "realizar cadastro no site" das transações de primeira compra

Fonte: Dados coletados no experimento com os consumidores

O experimento realizado com os consumidores possibilitou a construção parcial do Mapa de Consumo observado na Figura 27. 


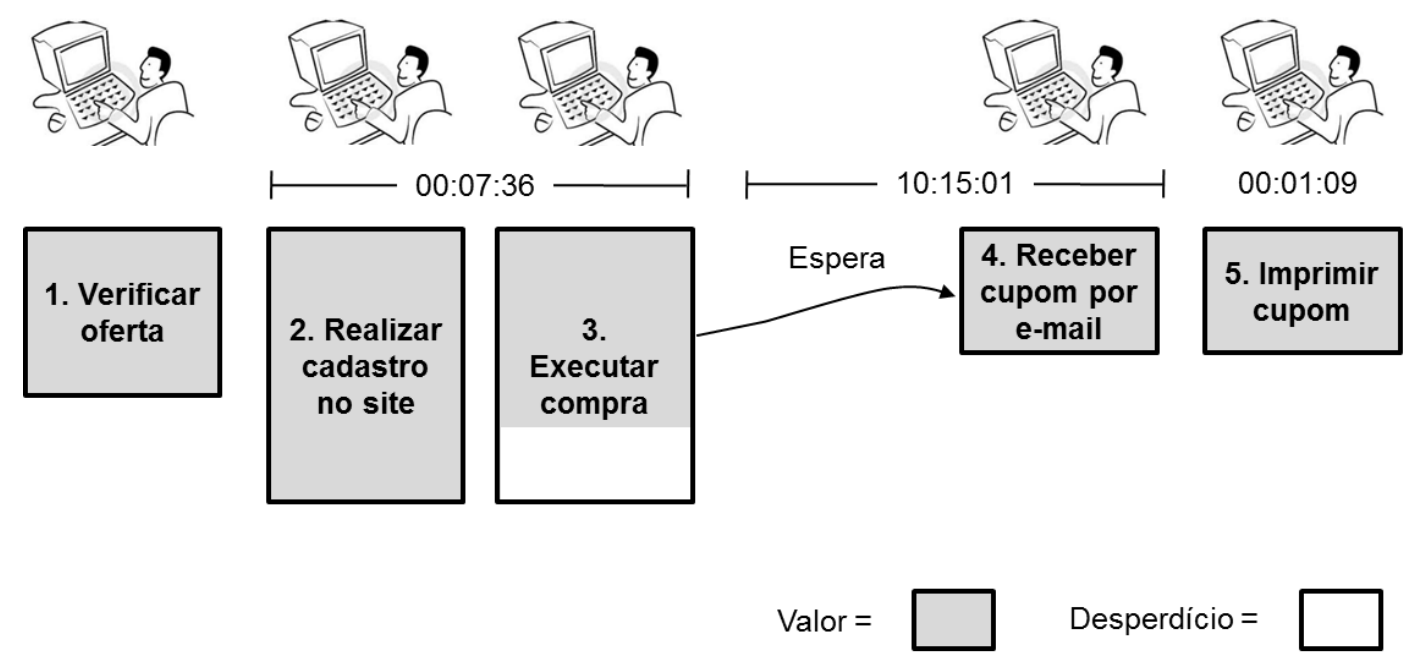

Figura 27 - Mapa de Consumo construído através dos dados do experimento

O mapa apresentado segue as características do modelo de representação estabelecido por Womack e Jones (2006) indicando, ainda que forma parcial, os seguintes aspectos:

(a) fluxo do processo detalhando as ações desempenhadas pelo consumidor;

(b) forma de interação entre consumidor e empresa;

(c) tempo gasto pelo consumidor para execução das tarefas;

(e) segregação dos tempos em que há e não há agregação de valor.

O critério utilizado para especificar valor e desperdício foi extraído das observações realizadas pelos consumidores no experimento, ou seja, considerou-se que houve uma parcela de desperdício no tempo dedicado ao processo objeto de estudo quando o consumidor inseriu algum comentário na coluna "observação" da planilha (ver Tabela 8) sobre retrabalho, espera ou desperdícios que tenha vivenciado durante o fluxo do processo.

Alguns consumidores relataram que tiveram retrabalho na execução da compra o que resultou na atribuição de um percentual de desperdício para a tarefa 3 . Os consumidores também indicaram que o tempo de espera para receber o cupom por e-mail geralmente é bastante alto. Isso motivou a alocação de um alto percentual de desperdício na tarefa 4 . Vale ressaltar que alguns sites de compra coletiva já se adaptaram à necessidade do consumidor em receber o cupom o mais breve possível 
após a execução da compra. Os desperdícios identificados no caso estudado resultaram da avaliação dos consumidores que participaram da pesquisa e representam de forma parcial o tempo em que não houve agregação de valor em cada uma das tarefas sendo que pode ter ocorrido outros tempos associados a desperdícios que não puderam ser identificados por meio do método de pesquisa empregado.

A versão do Mapa de Consumo apresentado na Figura 27 adere parcialmente ao padrão de representação proposto por Womack e Jones (2006). Embora esta versão contenha mais detalhes que a versão apresentada na Figura 26, ela ainda não indica o grau de satisfação dos consumidores e, tampouco, segrega os percentuais de tempo de valor agregado e de desperdício para todas as tarefas do processo de serviço.

\subsubsection{Análise dos dados complementares}

A execução do experimento permitiu, além da construção de uma nova versão de Mapa de Consumo para o processo de serviço objeto de estudo, coletar dados complementares que possibilitam análises mais específicas do processo e que podem auxiliar na identificação de oportunidades de melhoria.

Os dados complementares obtidos foram os seguintes:

- se compra registrada pelo consumidor era a primeira realizada naquele site de compra coletiva;

- a forma de pagamento adotada pelo consumidor - cartão de crédito ou débito em conta;

- observações do processo

Na planilha preenchida pelos consumidores apresentada na Tabela 8, estes dados foram registrados nas colunas 6,7 e 11 , respectivamente. 
A seguir são exemplificadas algumas análises que a empresa provedora do serviço de compra coletiva poderia realizar por meio dos dados complementares que a realização do experimento permitiu coletar. Embora o escopo desta pesquisa não englobe a melhoria do processo de compra coletiva estudado considerou-se relevante exemplificar possíveis análises que podem ser feitas com os dados complementares coletados e, assim, servir de base para o desenvolvimento de propostas de melhoria no processo do consumidor, a fim de minimizar o esforço do consumidor.

Ao analisar a distribuição do tempo despendido pelo consumidor para "executar a compra", verifica-se a existência de alguns tempos substancialmente maiores do que a média. Tais outliers estão destacados no Gráfico 12 e puderam ser analisados de forma mais detalhada com base nos registros inseridos pelos consumidores na coluna "Observação" da planilha de coleta de dados. Verifica-se que nos 3 pontos de distorção identificados, quais sejam, as transações de número 2, 10 e 16, o consumidor teve problemas para executar a compra e teve que refazer o processo, o que certamente exigiu mais tempo para finalização da tarefa.

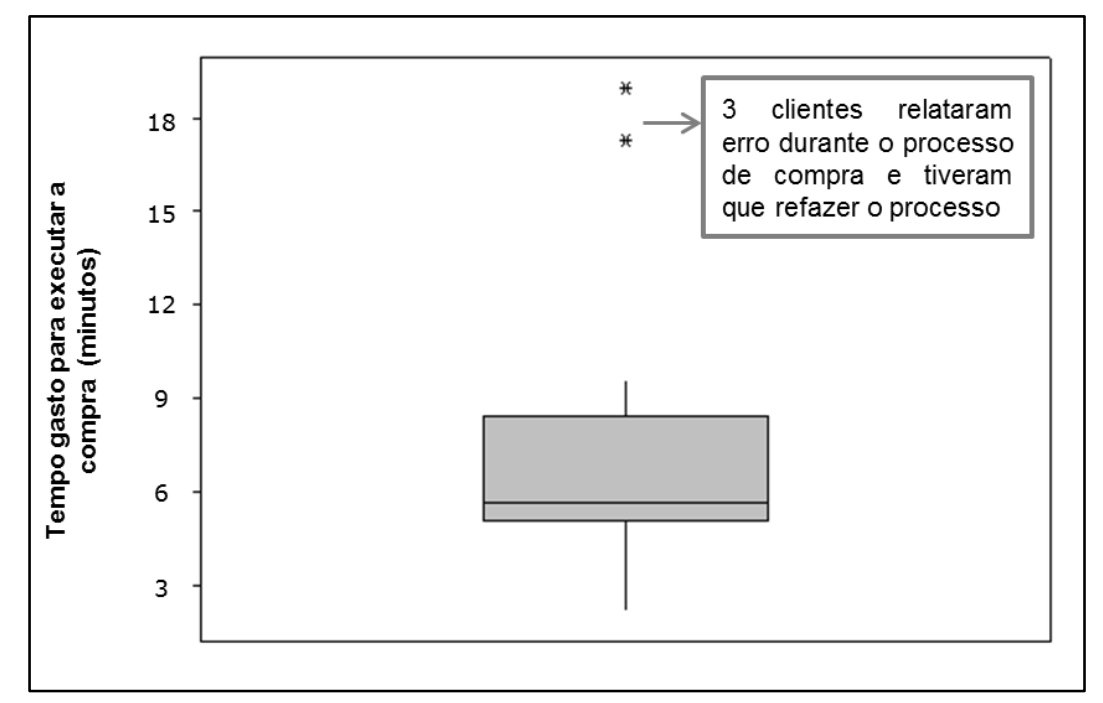

Gráfico 12 - Boxplot do tempo gasto pelos consumidores para executar a compra

No Gráfico 13, a distribuição do tempo para "executar a compra" é estratificada distinguindo os dados de consumidores que já haviam feito uma compra anterior no 
site dos dados daqueles que não. Esta estratificação indica que o consumidor que compra pela primeira vez no site demora mais tempo para executar esta tarefa que aquele que já havia comprado pelo mesmo site anteriormente. Além disso, as primeiras compras dos consumidores em um site resultaram em um desvio padrão muito maior no tempo de execução da compra. Isso pode ser devido aos diferentes tipos de cadastros que os consumidores são obrigados a preencher pelos sites em sua primeira compra.

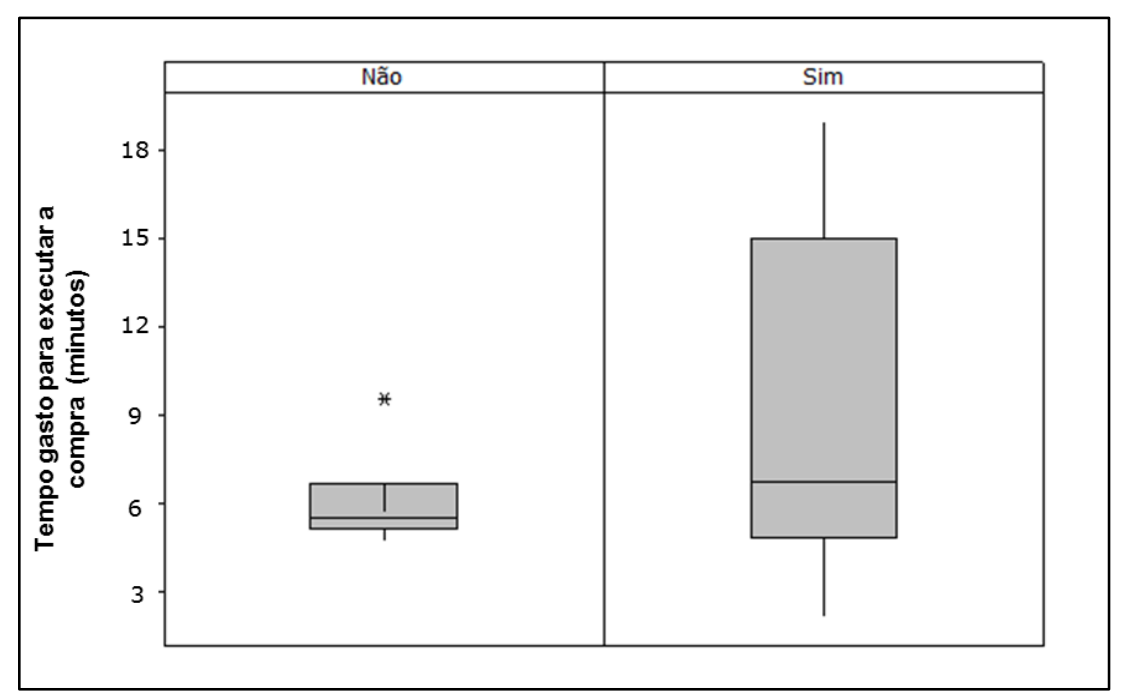

Gráfico 13 - Boxplot do tempo gasto pelos consumidores para executar a compra estratificados em subgrupos formados por aqueles que fizeram a primeira compra pelo site ou não

Outra análise que pode ser feita refere-se à forma de pagamento adotada em cada transação de compra. Como se pode observar no Gráfico 14, os consumidores que utilizam cartão de crédito levam mais tempo para finalizar a compra do que os que utilizam o débito em conta. 


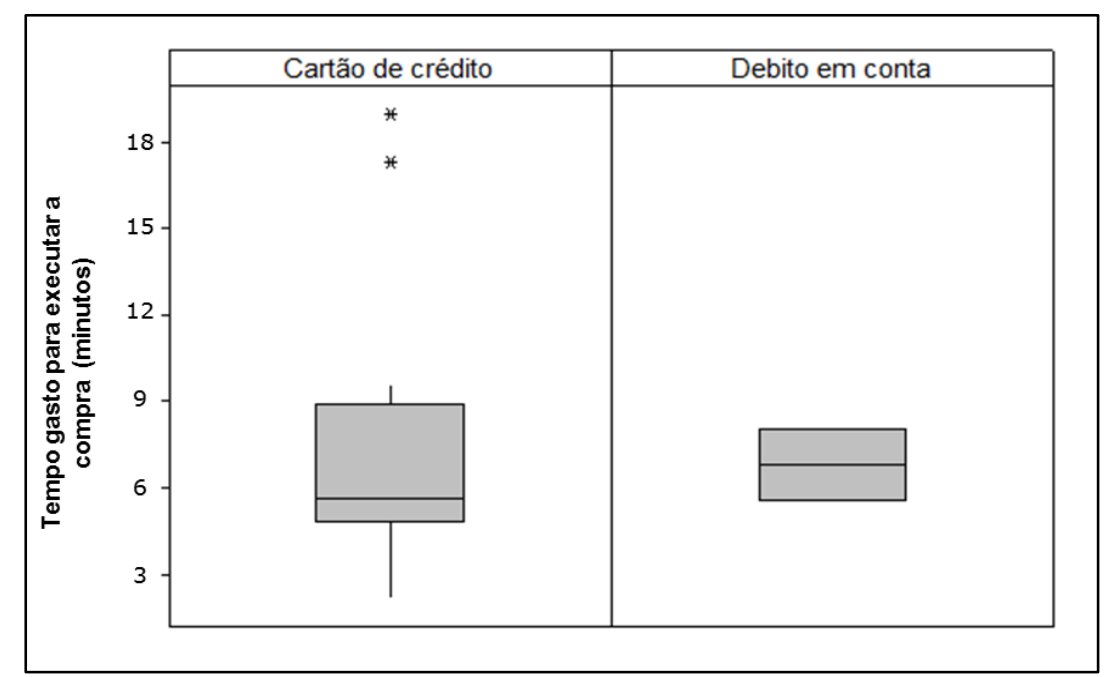

Gráfico 14 - Boxplot do tempo gasto pelos consumidores para executar a compra, agrupados pelo subgrupo forma de pagamento

Embora a análise das causas que levam certos consumidores a demorar mais tempo do que outros para executar o processo estudado ou dos fatores que contribuem para aumentar o esforço do consumidor não façam parte do escopo desta pesquisa, a construção dos Gráficos 12, 13 e 14 com base em dados obtidos pelo método do experimento - no qual se conta com a colaboração de consumidores no registro de dados referentes às tarefas por eles desempenhadas remotamente serviu para mostrar que esta abordagem possibilita à empresa provedora do serviço buscar uma melhor visualização de seu processo e assim identificar oportunidades de melhorias.

Por meio desta abordagem, de acordo com o tipo de processo de serviço a ser estudado e com as necessidades específicas de cada empresa, pode-se definir de forma bem flexível os dados complementares a serem coletados junto aos consumidores. Inúmeras possibilidades de análise podem ser viabilizadas por meio deste método de coleta de dados, mas é importante frisar que quanto maior a quantidade de dados exigidos do consumidor, maior será o esforço para obtê-los e, consequentemente, maior o risco de baixa de taxa de adesão dos consumidores à medição, o que pode até inviabilizar o estudo.

No serviço objeto de estudo poder-se-ia, por exemplo, procurar coletar dados sobre a percepção do consumidor em relação ao valor agregado de cada tarefa que precisa realizar no processo de compra. Dados assim obtidos possibilitariam incluir 
no Mapa de Consumo o grau de satisfação do consumidor com o processo realizado seguindo a prescrição de Womack e Jones (2006). Informações complementares assim obtidas possibilitaram à empresa provedora do serviço a realização de análises ainda mais específicas.

\subsubsection{Estudo de Caso e Experimento Consolidados}

Os dados coletados junto à empresa provedora do serviço, por meio dos métodos de estudo de caso e experimento permitiram a construção de duas versões para o Mapa de Consumo do processo de compra coletiva as quais são ilustradas nas Figura 26 e Figura 27.

A consolidação dos dados coletados por ambos os métodos permite ainda a construção de uma terceira versão para o Mapa de Consumo que tem tanto a empresa como o consumidor como fontes de dados. Na Figura 28 é apresentada esta versão do Mapa de Consumo do processo de compra coletiva que conjuga os dados coletados no estudo de caso e no experimento.

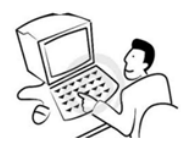

00:02:39

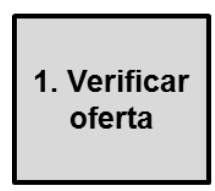

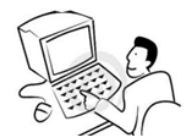

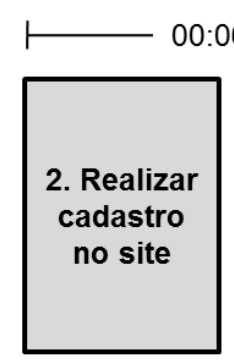

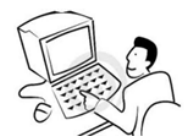
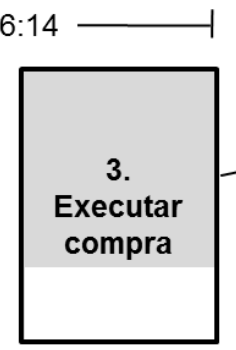

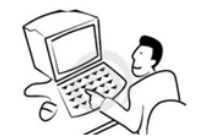

10:15:01
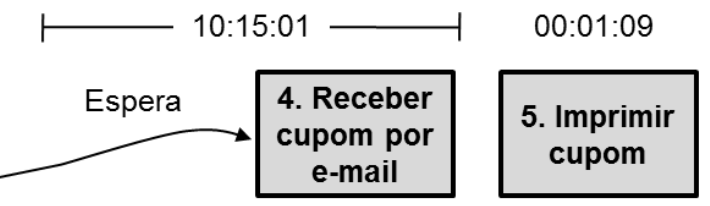

00:01:09
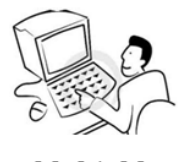

Imprimi

Valor $=$

Desperdício $=$

Figura 28 - Mapa de Consumo construído com base em dados levantados por meio do estudo de caso em uma empresa e do experimento com os consumidores

Conforme se visualiza na Figura 28 esta versão do mapa é mais completa que o mapa da Figura 26, construído somente com os dados levantados junto à empresa 
estudada, e o mapa da Figura 27, construído apenas com os dados coletados junto aos consumidores.

Nesta versão, para a tarefa "verificar oferta" foi considerado o dado levantado pela realização do estudo de caso, enquanto para as tarefas "receber cupom por e-mail" e "imprimir cupom" foram considerados os dados obtidos por meio do experimento. Já para a sequência de tarefas "realizar cadastro no site" e "executar compra" o seu tempo foi estimado pela média das medidas de tempo que foi possível obter por ambos os métodos.

Os percentuais de valor e desperdício atrelados às tarefas derivaram do Mapa de Consumo da Figura 27 construído por meio do experimento, pois os dados extraídos do estudo de caso não possibilitaram segregar valor e desperdício para nenhuma das tarefas do processo.

O Mapa de Consumo assim consolidado incorpora os seguintes aspectos do modelo de representação proposto por Womack e Jones (2006):

(a) fluxo do processo detalhando as tarefas desempenhadas pelo consumidor;

(b) forma de interação entre consumidor e empresa;

(c) tempo gasto pelo consumidor para execução das tarefas e

(e) segregação dos tempos em que há e não há agregação de valor.

A aplicação dos métodos de pesquisa abordados neste capítulo permitiu a coleta de diferentes dados e revelou dificuldades práticas, bem como pontos positivos específicos de cada um deles, os quais serão tratados no Capítulo 6. 


\section{DESCRIÇÃO E ANÁLISE DO PROCESSO COM INTERAÇÃO PRESENCIAL}

Uma vez exploradas no Capítulo 4 a aplicação dos métodos de estudo de caso e realização do experimento para procurar obter dados remotamente, tendo a empresa provedora do serviço e os consumidores, respectivamente, como fonte de dados, no presente capítulo, é explorada a abordagem de construção do Mapa de Consumo apoiada na coleta de dados por meio de uma enquete presencial realizada junto aos consumidores.

Conforme o escopo delimitado, a exploração do processo de construção do Mapa de Consumo é aqui considerado no contexto dos processos de serviço do tipo "faça você mesmo" com interação presencial tomando-se como objeto de estudo o processo de estacionar o carro em um shopping center.

O processo de estacionar o carro em um shopping center é bastante cotidiano para as pessoas que moram em grandes cidades como São Paulo. Os consumidores que desejam ir até um shopping center e que dispõem de um veículo podem recorrer ao serviço de estacionamento dentro destes espaços.

$\mathrm{Na}$ maioria dos shopping centers este serviço de estacionamento é pago de acordo com a quantidade de horas em que o carro permanece estacionado e oferece ao cliente um local seguro enquanto este busca e/ou consome bens ou serviços que podem ser lá encontrados ou simplesmente passeia para ver as ofertas. Devido à demanda de consumidores que não se sentem satisfeitos em gastar tempo procurando uma vaga para seus carros, muitos shopping centers também disponibilizam um serviço diferenciado de vallet no qual o cliente paga um valor adicional para que um funcionário da empresa prestadora do serviço estacione seu veículo na chegada e o busque na saída.

Em outras situações, entretanto, o cliente não opta pelo serviço de vallet e sua insatisfação com o tempo exigido para conseguir estacionar o carro pode levá-lo a desistir de usar o serviço de estacionamento e, por consequência, deixar de ir ao shopping center. 
No contexto do presente estudo, o processo de estacionar o carro em que o consumidor não utiliza o serviço de vallet, ou seja, quando ele mesmo é responsável por encontrar uma vaga e parar o veículo pode ser caracterizado como um outro exemplo do processo de serviço do tipo "faça você mesmo".

Conforme explicitado na seção 3.2.1, para a exploração do processo de construção do Mapa de Consumo de um processo do tipo "faça você mesmo" com interação presencial decidiu-se adotar o método da enquete. A aplicação deste método consiste na realização de entrevistas estruturadas com os consumidores do serviço estudado, utilizando um formulário elaborado para guiar a coleta e registro dos dados (APÊNDICE E).

Os dados coletados por meio da enquete podem ser divididos em duas categorias: dados básicos e dados complementares. Os dados básicos referem-se às informações essenciais para viabilizar a construção do Mapa de Consumo. Para o processo de estacionamento tomado como objeto do estudo, os dados essenciais seriam os seguintes: horário registrado no ticket de estacionamento do consumidor, horário em que o consumidor foi abordado para a entrevista na porta de entrada do shopping center e satisfação do consumidor com o processo de estacionar o carro.

Para capturar a percepção do consumidor em relação a sua satisfação na execução do processo foram utilizadas as figuras propostas por Womack e Jones (2006), conforme se destacou na Figura 14. Entretanto, no teste da enquete realizado com alguns consumidores identificou-se a necessidade de associar mais explicitamente cada desenho a um grau de satisfação. Desta forma, para cada figura proposta por Womack e Jones (2006) foi atribuído um grau de satisfação do consumidor, tal como ilustra a Figura 29, uma vez que os autores não deixaram explícito a que cada figura se referia.

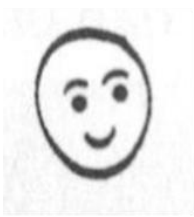

Satisfeito

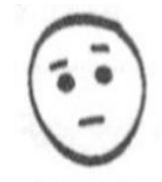

Indiferente

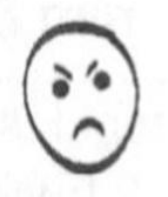

Insatisfeito

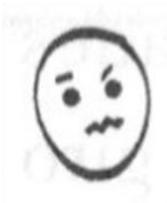

Nervoso

Figura 29 - Representação do grau de satisfação do consumidor em relação ao processo de estacionar o carro 
Os dados complementares coletados através da enquete são os seguintes: quantidade de consumidores que se dispuseram a participar da enquete, se o consumidor estacionou o veículo em algum tipo de vaga especial e, por fim, uma questão aberta caso o consumidor quisesse manifestar alguma observação a respeito do processo. Apesar destes dados não serem necessários para a construção do Mapa de Consumo, sua análise permite ampliar a compreensão do processo e de suas particularidades podendo contribuir na identificação de oportunidades de melhoria.

\subsection{MAPEAMENTO DO PROCESSO}

O primeiro passo para a construção do Mapa de Consumo do processo de estacionar o carro foi identificar as tarefas que são executadas pelo consumidor. Para entender como as tarefas executadas pelos consumidores podem ser mapeadas (Q2), os seguintes passos foram seguidos no estudo do processo de estacionar o carro em um shopping center:

- colocar-se na posição do consumidor do processo objeto de estudo desempenhando as tarefas que Ihe são atribuídas;

- esquematizar uma versão inicial do fluxo do processo identificando as tarefas desempenhadas pelo consumidor;

- validar o fluxo esquematizado observando presencialmente os consumidores enquanto estes experimentam o serviço objeto de estudo;

- incorporar os ajustes necessários para validar o esquema do fluxo das tarefas executadas pelos consumidores;

O mapa do processo explicitado na Figura 30 considera o fluxo desde o momento em que o consumidor entra no estacionamento do shopping center, passando por uma cancela até o momento em que sai do estacionamento e entra na área de acesso às lojas. 


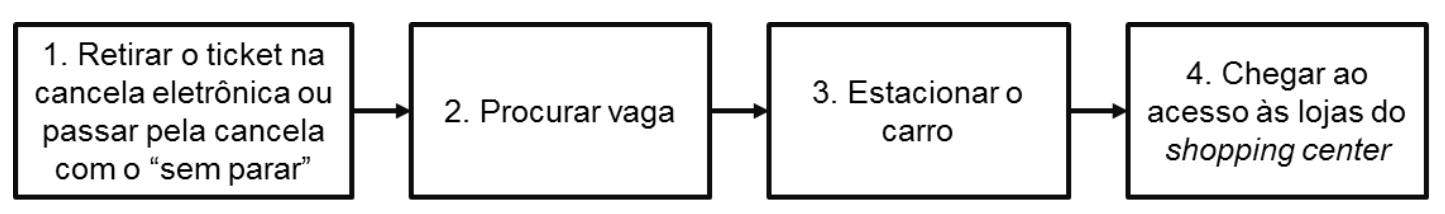

Figura 30 - Mapa do processo das tarefas executadas pelo consumidor no processo de estacionar o carro

Durante a validação do fluxo foram identificados desdobramentos do processo descrito na Figura 30 o que possibilitou a construção de um mapa detalhado das tarefas realizadas pelo consumidor, conforme obtido na Figura 31.

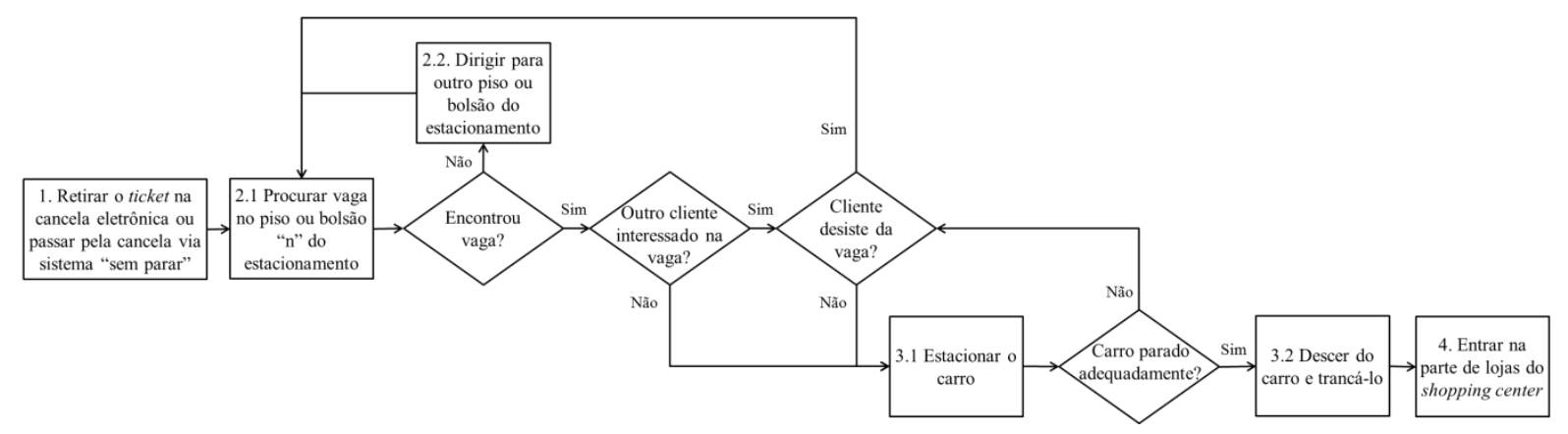

Figura 31 - Mapa detalhado das tarefas executadas pelo consumidor no processo de estacionar o carro em shopping center

Conforme verificado na Figura 31 existem algumas tarefas sujeitas a um looping dentro do processo, ou seja, pode ocorrer retrabalho do consumidor durante a procura por uma vaga para estacionar o carro. Algumas vezes, o consumidor necessita percorrer diversos pisos ou bolsões de estacionamento até encontrar uma vaga disponível e adequada para seu veículo.

Além disso, observou-se outra variável que pode influenciar a realização deste serviço do tipo "faça você mesmo" com interação presencial: outros consumidores que estão presentes durante o serviço. A interação do consumidor objeto do estudo com outros consumidores pode ocorrer de diferentes formas, ou seja:

- pode haver consumidores que estejam também procurando vagas para estacionar seus veículos e venham a disputar uma mesma vaga;

- um consumidor pode estar saindo de uma vaga na qual o consumidor estudado pretende estacionar; 
- outros consumidores podem estar circulando no mesmo ambiente do consumidor estudado e de alguma forma interagir com o consumidor estudado durante o trajeto percorrido na procura por uma vaga ou durante $o$ trajeto de caminhada do consumidor até o acesso à área de lojas do shopping center.

Esta interação entre consumidores mostra-se uma característica importante nos serviços executados presencialmente e pode influenciar a percepção do cliente em relação ao serviço prestado.

Mesmo com os desdobramentos observados no mapa de processo detalhado, o processo de estacionar o carro em um shopping center pode ser caracterizado como um processo único, sem muitas ramificações e, portanto, adequado para a análise da viabilidade de aplicação da ferramenta Mapa de Consumo a um serviço do tipo "faça você mesmo" com interação presencial.

\subsection{MEDIÇÃO DAS TAREFAS EXECUTADAS PELO CONSUMIDOR}

As perguntas que compuseram a enquete foram estruturadas para apoiar a construção do Mapa de Consumo do processo objeto de estudo tendo como fim a coleta de dados sobre o tempo gasto pelo consumidor na realização do processo e sua satisfação em relação às tarefas que teve de executar (Q3).

Adicionalmente, a observação in loco do processo permitiu verificar variáveis complementares que poderiam ser coletadas pela realização da enquete. Embora os dados complementares coletados não estejam relacionados com o foco desta pesquisa - analisar a viabilidade de construção e aplicação da ferramenta Mapa de Consumo -, eles servem para exemplificar algumas análises mais específicas que poderiam ser realizadas em relação ao processo e à participação do consumidor. 


\subsubsection{Enquete}

A enquete foi executada em dois dias distintos da semana, um dia de final de semana (domingo, 01/04/2012) e um dia útil (quinta-feira, 05/04/2012). Em cada um dos dias a pesquisadora assumindo o papel de um analista responsável por levantar dados para construir o Mapa de Consumo de um dado processo, dedicou duas horas para coleta de dados junto aos consumidores.

O estabelecimento escolhido para realização da pesquisa é o estacionamento de um shopping center da capital paulistana, localizado na região central da cidade com grande circulação de pessoas durante a semana e aos finais de semana. $O$ estacionamento possui aproximadamente 3.500 vagas para carros distribuídos em diversos pavimentos e não dispõe de funcionários ou sistemas que facilitem a procura do consumidor por uma vaga desocupada.

5.2.1.1 Análise dos dados para construção do Mapa de Consumo

O formulário de coleta de dados utilizado na enquete foi estruturado de modo a facilitar a realização das perguntas para os consumidores de forma rápida e sucinta para não exigir muito tempo do consumidor e, ao mesmo tempo, facilitar o preenchimento dos dados necessários à construção do mapa pela pesquisadora.

As respostas obtidas na enquete foram registradas em planilhas que se encontram no APÊNDICE F. Na Figura 32 é apresentado um extrato dos dados obtidos. 


\begin{tabular}{|c|c|c|c|c|c|c|c|c|c|}
\hline Amostra & $\begin{array}{l}\text { Aceitou (S/N) } \\
\text { Participar }\end{array}$ & $\begin{array}{l}\text { Horário do } \\
\text { Ticket }\end{array}$ & $\begin{array}{l}\text { Horário da } \\
\text { Medição }\end{array}$ & $\begin{array}{c}\text { Tempo Gasto para } \\
\text { Estacionar }\end{array}$ & Satisfação & $\begin{array}{c}\text { Vaga } \\
\text { Especial }\end{array}$ & Observação & Comentário do consumidor & Data \\
\hline 1 & Sim & $17: 37$ & $17: 44$ & $0: 07$ & Indiferente & Não & & & $01 / 04 / 2012$ \\
\hline 2 & Sim & $17: 43$ & $17: 45$ & $0: 02$ & Satisfeito & Não & & & $01 / 04 / 2012$ \\
\hline 3 & Sim & $17: 38$ & $17: 46$ & $0: 08$ & Nervoso & Não & & $\begin{array}{l}\text { Sempre demoro muito para } \\
\text { encontrar uma vaga aqui }\end{array}$ & $01 / 04 / 2012$ \\
\hline 4 & Sim & $17: 40$ & $17: 49$ & 0:09 & Satisfeito & Não & & & $01 / 04 / 2012$ \\
\hline 5 & Não & & & & & Não & & & $01 / 04 / 2012$ \\
\hline 6 & Sim & $17: 17$ & $17: 52$ & $0: 35$ & Nervoso & Não & & $\begin{array}{c}\text { Neste shopping não existem } \\
\text { vagas suficientes }\end{array}$ & $01 / 04 / 2012$ \\
\hline 7 & Sim & $17: 47$ & $17: 54$ & 0:07 & Satisfeito & Sim & & & $01 / 04 / 2012$ \\
\hline 8 & Sim & - & $17: 55$ & $0: 05$ & Insatisfeito & Não & Sem parar & $\begin{array}{l}\text { Tenho dificuldade para estacionar, } \\
\text { pois tenho uma caminhonete }\end{array}$ & $01 / 04 / 2012$ \\
\hline 9 & Sim & - & $17: 57$ & $0: 08$ & Satisfeito & Não & Sem parar & & $01 / 04 / 2012$ \\
\hline 10 & Sim & - & $17: 57$ & $0: 05$ & Insatisfeito & Não & Sem parar & & $01 / 04 / 2012$ \\
\hline 11 & Sim & $17: 54$ & $17: 59$ & $0: 05$ & Indiferente & Não & & & $01 / 04 / 2012$ \\
\hline 12 & Sim & $17: 59$ & 18:05 & 0:06 & Insatisfeito & Não & & Exitem muitas vagas para idosos & $01 / 04 / 2012$ \\
\hline 13 & Sim & - & 18:07 & $0: 05$ & Satisfeito & Não & Sem parar & & $01 / 04 / 2012$ \\
\hline 14 & Sim & - & $18: 13$ & $0: 05$ & Satisfeito & Não & Sem parar & & $01 / 04 / 2012$ \\
\hline 15 & Sim & $18: 15$ & $18: 22$ & $0: 07$ & Indiferente & Não & & & $01 / 04 / 2012$ \\
\hline 16 & Não & & & & & & & & $01 / 04 / 2012$ \\
\hline 17 & Sim & $18: 17$ & 18:22 & 0:05 & Satisfeito & Não & & $\begin{array}{c}\text { Venho muito aqui e já sei onde } \\
\text { encontrar vaga }\end{array}$ & $01 / 04 / 2012$ \\
\hline 18 & Sim & - & $18: 23$ & $0: 03$ & Indiferente & Não & Sem parar & & $01 / 04 / 2012$ \\
\hline 19 & Sim & - & 18:24 & $0: 05$ & Indiferente & Não & Sem parar & As vagas são muito pequenas & $01 / 04 / 2012$ \\
\hline 20 & Sim & - & 18:25 & 0:05 & Satisfeito & Não & Sem parar & & $01 / 04 / 2012$ \\
\hline
\end{tabular}

Figura 32 - Um extrato dos dados obtidos por meio da enquete

Os tempos medidos para a tarefa de estacionar o carro foram obtidos de duas formas. Para os casos onde o cliente retirou um ticket na catraca de entrada do estacionamento, o tempo gasto com o processo, retratado no Gráfico 15, foi calculado por meio da diferença entre o horário de abordagem do consumidor para execução da enquete e o horário de registro do ticket de entrada em posse do cliente.

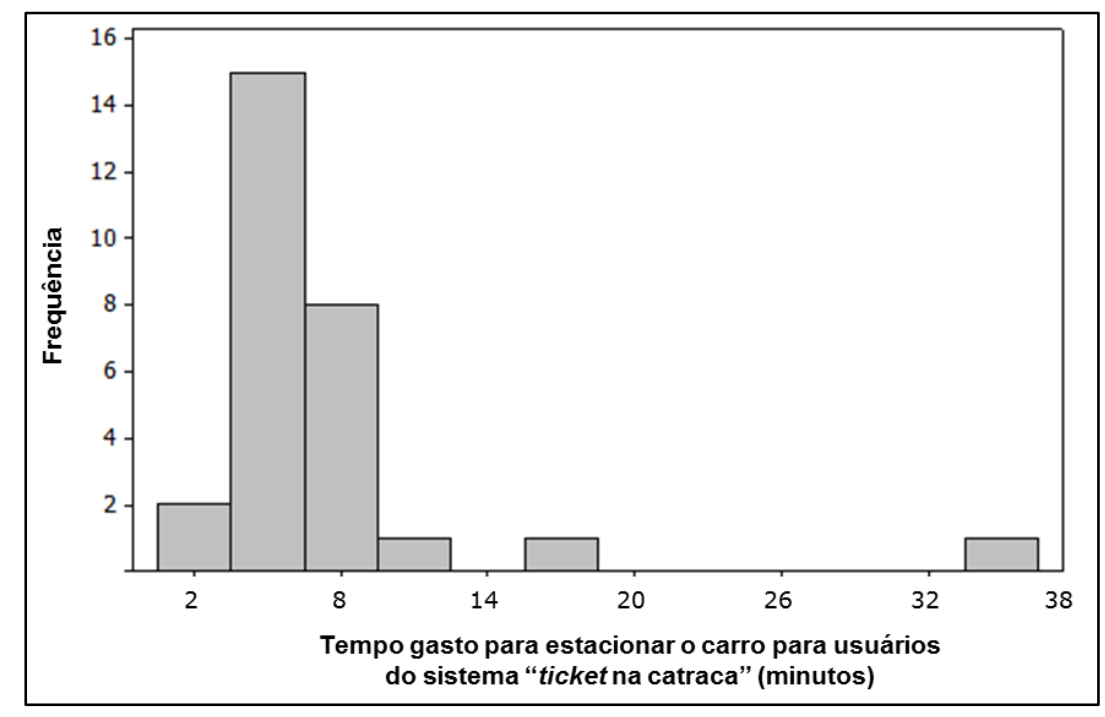

Gráfico 15 - Histograma do tempo gasto para estacionar o carro utilizando o ticket do estacionamento 
Outra forma de medir o tempo gasto pelo consumidor para estacionar o carro surgiu durante a execução da enquete quando a pesquisadora se deparou com clientes que não possuíam o ticket do estacionamento, pois haviam utilizado o sistema "sem parar"7. Nestes casos, os tempos apresentados no Gráfico 16 foram estimados e fornecidos pelos próprios consumidores ao serem perguntados quanto tempo haviam gasto para estacionar seu carro.

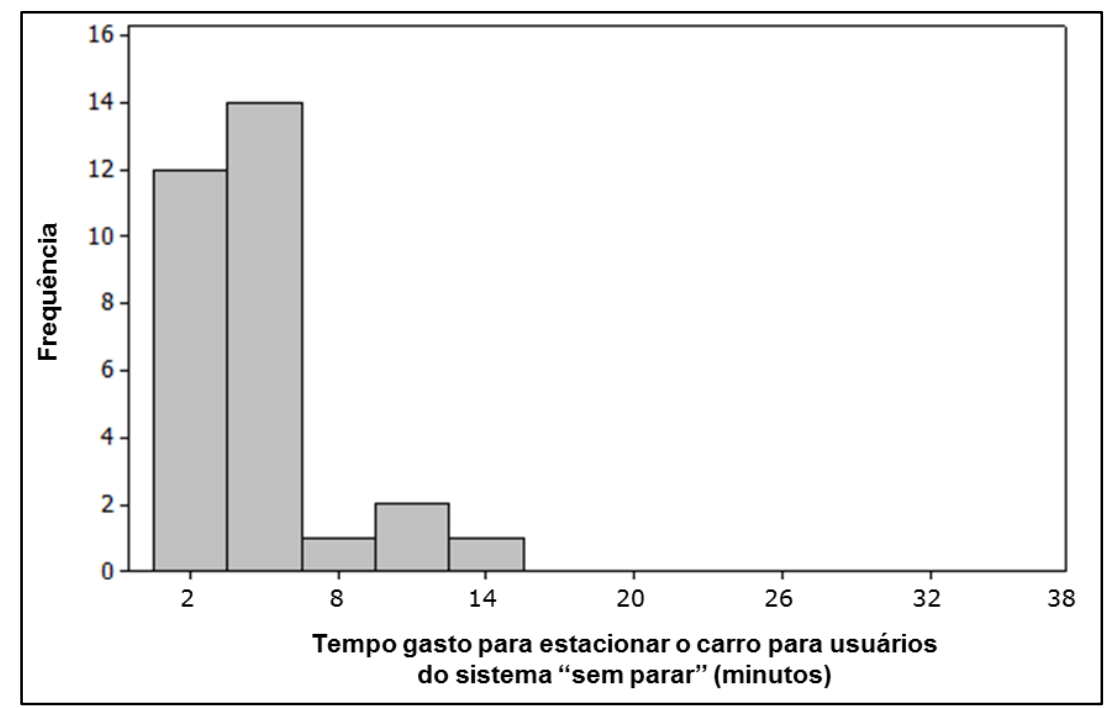

Gráfico 16 - Histograma do tempo gasto para estacionar o carro utilizando o sistema "sem parar".

A comparação do Gráfico 15 com o Gráfico 16 permite verificar que o tempo gasto para estacionar o carro utilizando o sistema "sem parar" é menor do que quando o consumidor tem de retirar o ticket da catraca. Na Tabela 10 são apresentados os tempos máximos, médios, mínimos e medianas dos dados coletados, segregando os tempos dos que recorreram ao sistema "ticket na catraca" dos tempos daqueles que utilizaram o sistema "sem parar".

Tabela 10 - Tempo gasto para estacionar o carro em um shopping center

\begin{tabular}{lcc}
\hline & “Ticket na catraca” & Sistema "sem parar" \\
\hline Tempo Máximo & $00: 35: 00$ & $00: 15: 00$ \\
Tempo Médio & $00: 07: 00$ & $00: 04: 00$ \\
Mediana & $00: 06: 00$ & $00: 05: 00$ \\
Tempo Mínimo & $00: 02: 00$ & $00: 01: 00$ \\
\hline
\end{tabular}

7 O sistema "sem parar" é um tipo de serviço oferecido aos clientes que permite, através da instalação de um sensor no painel do veículo, passar por catracas de estacionamento e por pedágios sem ter que parar o veículo. 
A partir dos dados coletados na enquete foi possível construir dois Mapas do Consumo para o processo de estacionar o carro em um shopping center.

O primeiro mapa, apresentado na Figura 33, está associado ao fluxo dos consumidores que utilizaram o sistema "ticket na catraca", para o qual o tempo gasto com o processo foi medido pela diferença entre o horário registrado no ticket e o horário em que o consumidor respondeu as perguntas da enquete, utilizando o relógio da pesquisadora. Para assegurar maior exatidão dos dados assim obtidos, o relógio da pesquisadora foi inicialmente ajustado para indicar o mesmo horário do sistema que controla a emissão do ticket.

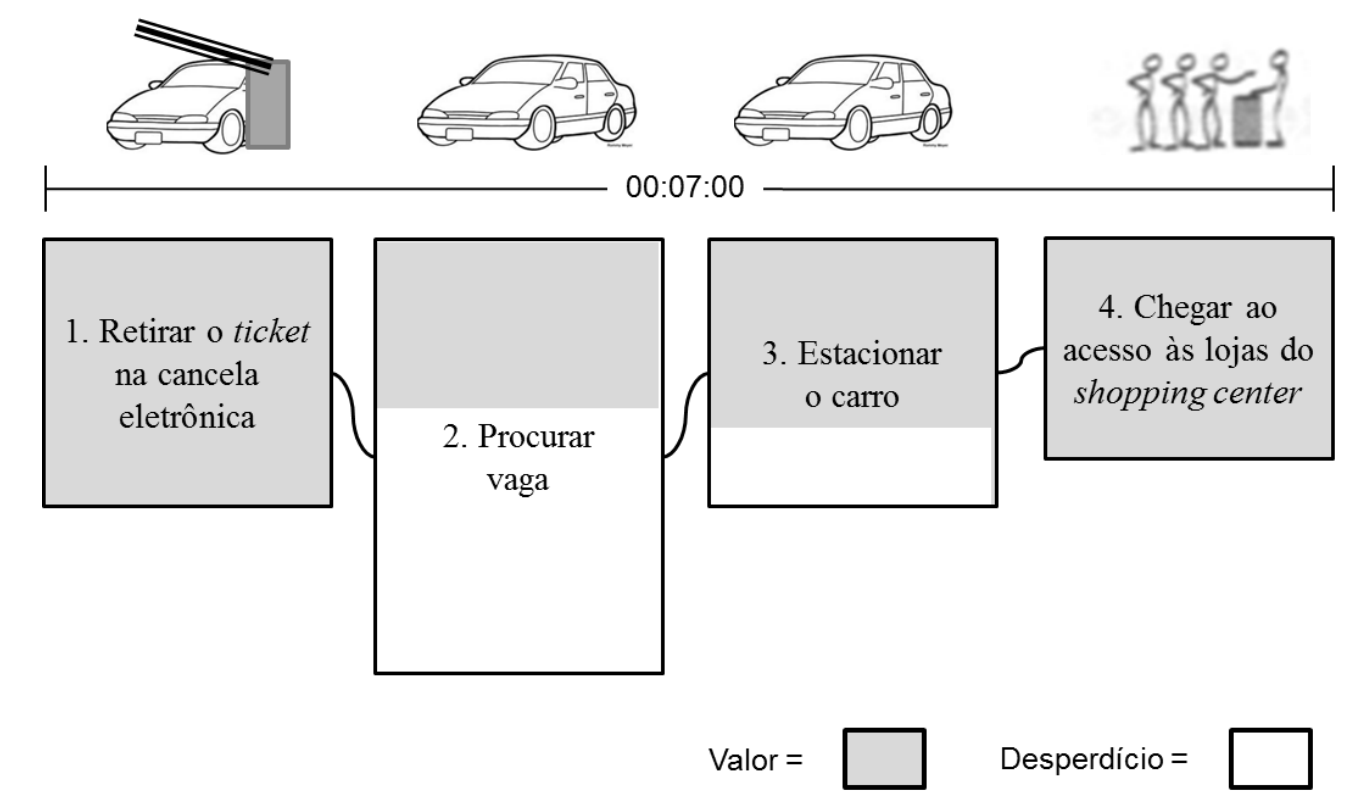

Figura 33 - Mapa de Consumo do processo de estacionar o carro no sistema "ticket na catraca"

O segundo Mapa de Consumo, apresentado na Figura 34, corresponde ao fluxo no sistema "sem parar". Nesta versão, os dados de tempo gasto para estacionar o carro foram estimados e fornecidos pelos próprios consumidores. Neste sentido, o Mapa de Consumo do processo de estacionar o carro no sistema "ticket na catraca" foi construído com base no tempo real gasto pelo consumidor, enquanto o Mapa de Consumo do processo de estacionar o carro no sistema "sem parar" foi construído com base na ótica do tempo percebido pelo consumidor. 


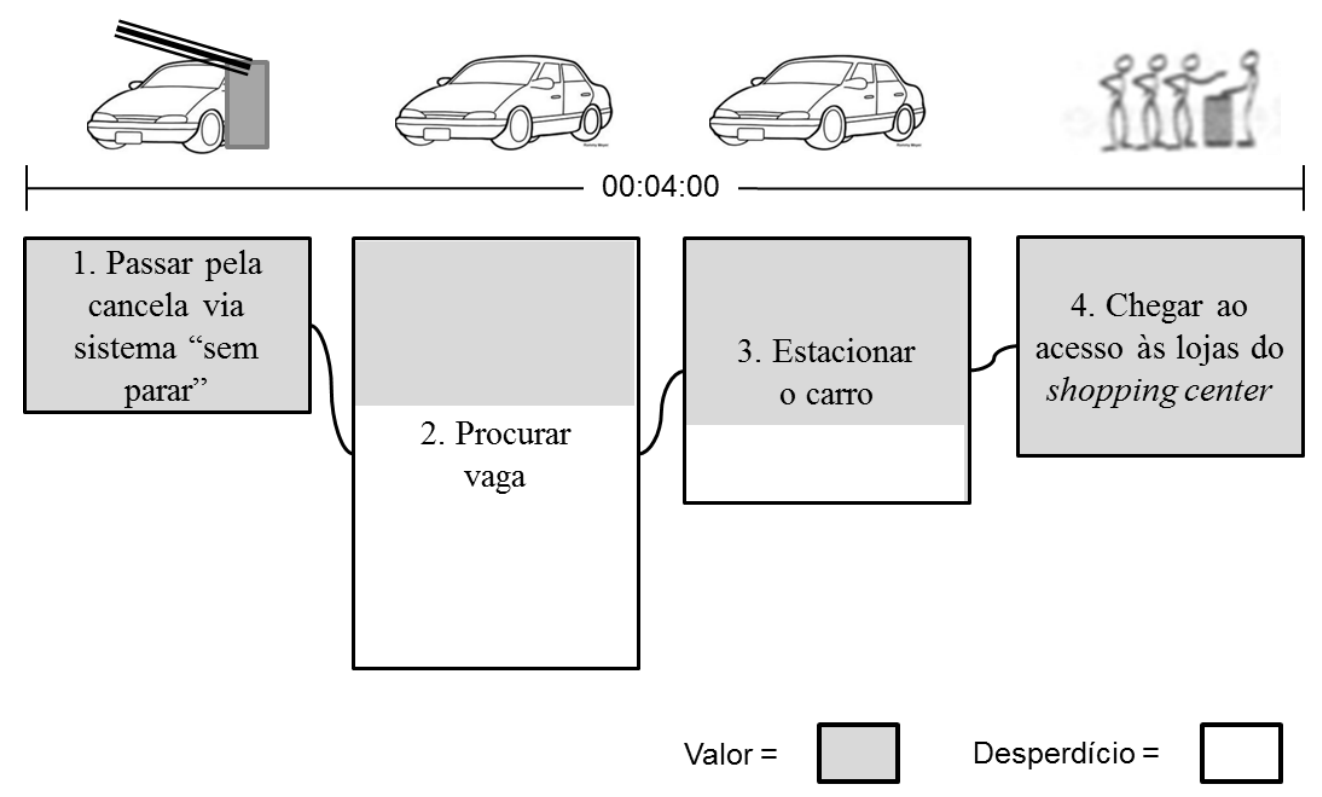

Figura 34 - Mapa de Consumo do processo de estacionar o carro no sistema "sem parar"

Em ambos os mapas, o percentual de tempo de execução de tarefas associado a desperdício foi estimado utilizando o mesmo critério adotado no experimento (ver seção 4.2.2.1), ou seja, foram considerados os comentários relatados pelos consumidores presentes na tabela do APÊNDICE $\mathrm{F}$ que remetem a retrabalho, desperdícios de tempo e ocorrência de espera durante o fluxo do processo do consumidor. As principais considerações dos consumidores estão associadas ao tamanho das vagas que são muito pequenas e exigem manobras para estacionar o veículo, ao fato do estacionamento estar sempre muito cheio e ao excesso de vagas especiais que ficam vazias ocasionando falta de vagas regulares.

Estes comentários dos consumidores associados à procura por vagas e a dificuldade de manobrar o carro foram incorporadas aos Mapas de Consumo atribuindo um percentual de desperdício as atividades "procurar vaga" e "estacionar o carro". Não foram relatados pelos consumidores fatos envolvendo os processos de "retirar o ticket na cancela eletrônica", "passar pela cancela via sistema "sem parar"” ou "chegar ao acesso às lojas do shopping center" e por esta razão não foi atribuída parcela de desperdício à estas tarefas, entende-se, entretanto, que podem ter ocorrido desperdícios associados à estas tarefas que não puderam ser levantados por meio do método de pesquisa adotado. 
Apesar das tarefas executadas pelos consumidores serem essencialmente as mesmas nos dois sistemas, a construção de dois mapas mostrou-se necessária, pois os dados de tempo gasto com o processo capturados no sistema "ticket na catraca" foram calculados por meio de um procedimento formal e objetivo de medição, enquanto no sistema "sem parar" o tempo coletado decorre da percepção do consumidor.

A adoção do método enquete no processo de construção do Mapa de Consumo para um serviço do tipo "faça você mesmo" com interação presencial mostrou-se viável. Os dados assim coletados possibilitaram visualizar a participação do consumidor em um processo no qual este atua como principal agente executor das tarefas, executando-as no ambiente do provedor do serviço.

Os Mapas do Consumo assim construídos incorporam os seguintes aspectos do modelo de representação proposto por Womack e Jones (2006):

(a) fluxo do processo detalhando as tarefas desempenhadas pelo consumidor;

(b) forma de interação entre consumidor e empresa;

(c) tempo gasto pelo consumidor para execução das tarefas;

(d) grau de satisfação ou incômodo do consumidor;

(e) segregação dos tempos em que há e não há agregação de valor.

\subsubsection{Análise dos dados complementares}

Os dados complementares coletados durante a realização da enquete permitem, além da construção do Mapa de Consumo, executar análises adicionais do processo que contribuem para o diagnóstico do processo de prestação do serviço. Um aspecto relevante que pode ser verificado é o grau de adesão dos consumidores à solicitação de participação na enquete respondendo as perguntas que lhes foram dirigidas. Conforme se pode verificar no Gráfico 17, na enquete realizada no 
domingo 79\% dos consumidores aceitaram participar da pesquisa, enquanto na quinta-feira o percentual de adesão foi de $54 \%$.

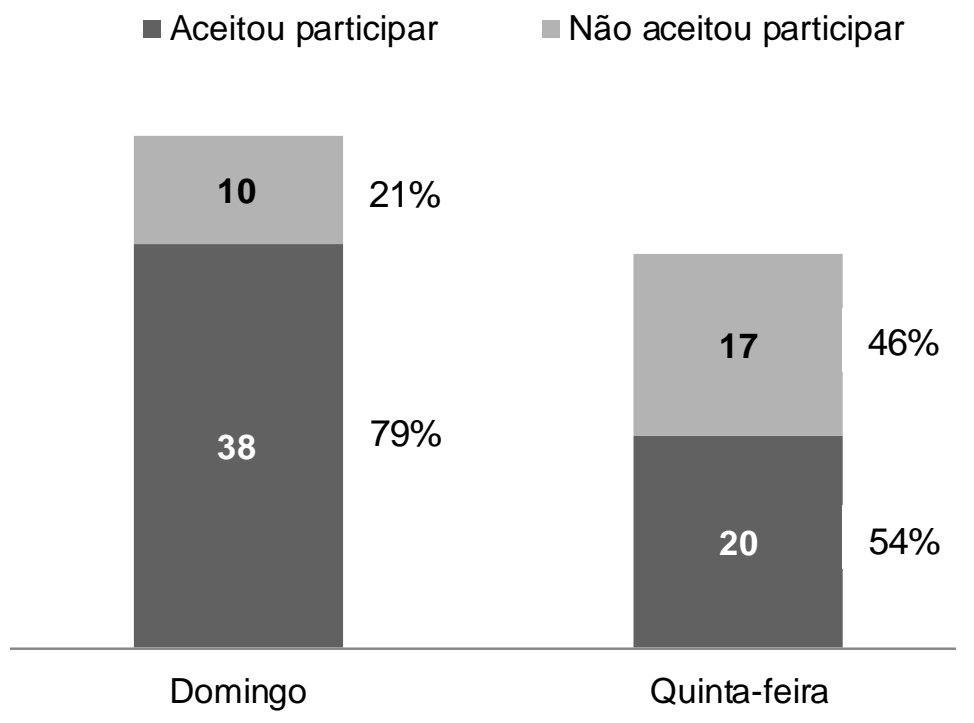

Gráfico 17 - Adesão dos consumidores a enquete

Apesar da importância das análises que seguem para compreensão do processo e avaliação do percentual de resposta da enquete, estas análises não fazem parte do escopo principal proposto por esta pesquisa, que objetiva avaliar a viabilidade de construção da ferramenta Mapa de Consumo para processos do tipo "faça você mesmo".

Uma análise que pode ser realizada com os dados complementares é avaliar a diferença de tempo gasto pelo consumidor quando este para em uma vaga especial ${ }^{8}$ e quando para em uma vaga comum. O boxplot do Gráfico 18 mostra que para consumidores que utilizaram o sistema "ticket na catraca" o tempo gasto por aqueles que estacionaram em uma vaga especial apresentou uma variação menor do que o tempo gasto pelos que estacionaram em uma vaga normal.

8 Vaga especial: vagas reservadas para idosos e pessoas com deficiência física 


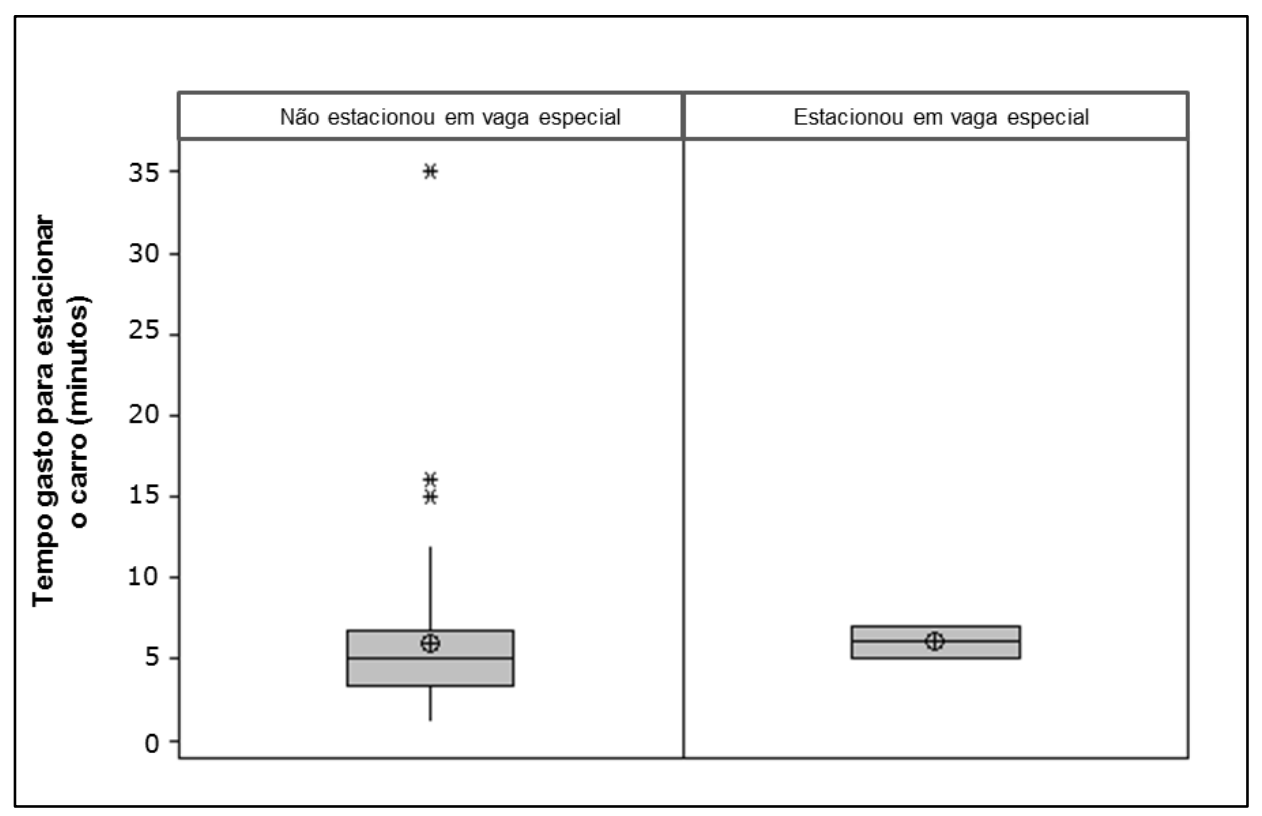

Gráfico 18 - Tempo gasto pelos consumidores que utilizaram o sistema "ticket na catraca" para estacionar em vaga comum e em vaga especial

Vale salientar alguns pontos que ajudam a compreender esta variação do processo. As vagas especiais disponíveis nos shoppings centers são geralmente posicionadas próximas aos pontos de acesso às lojas. Para estacionar neste tipo de vaga o consumidor pode gastar menos tempo na procura de uma vaga para seu carro, evitando os loopings do processo apontados na Figura 33 e, além disso, consegue acessar mais rapidamente as lojas e, consequentemente, pode realizar o processo em um fluxo mais contínuo e menos sujeito a grandes variações.

Dos consumidores entrevistados que utilizaram o sistema "sem parar" nenhum deles estacionou seu carro em vaga especial.

O processo ainda pode ser analisado segundo a perspectiva da satisfação do consumidor com a execução das tarefas.

Outro dado obtido por meio da enquete realizada com os consumidores foi o grau de satisfação destes com a execução do processo, separando consumidores que utilizaram o sistema "ticket na catraca" dos consumidores que utilizaram o sistema "sem parar" conforme se observa nos Gráficos 19 e 20, respectivamente. 


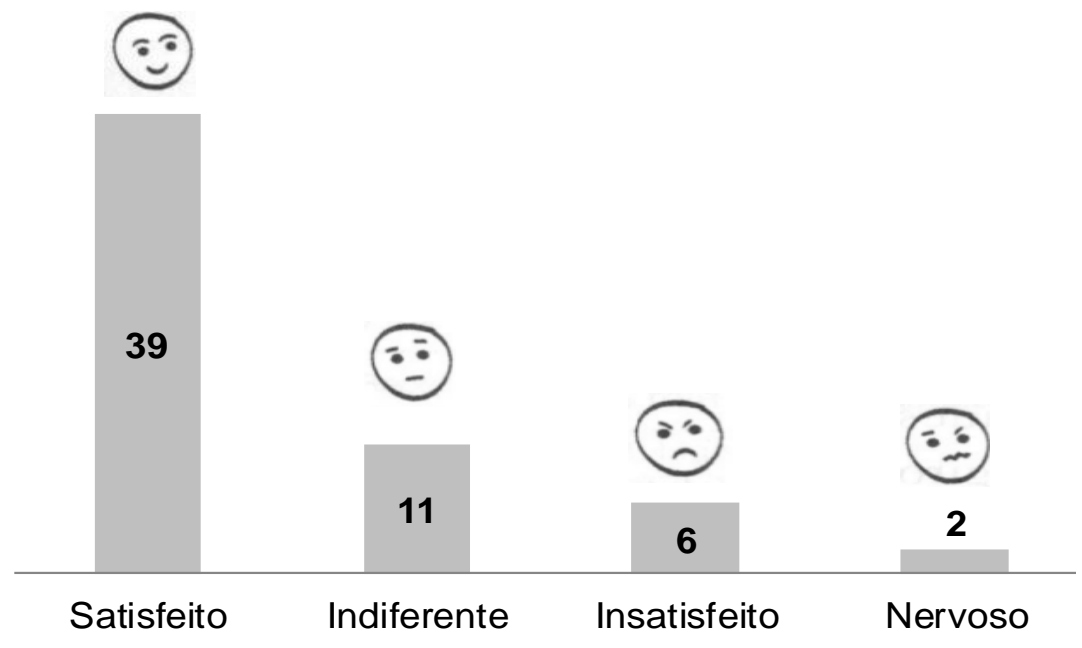

Gráfico 19 - Grau de satisfação dos consumidores que utilizaram o sistema "ticket na catraca" na execução do processo de estacionar o carro.

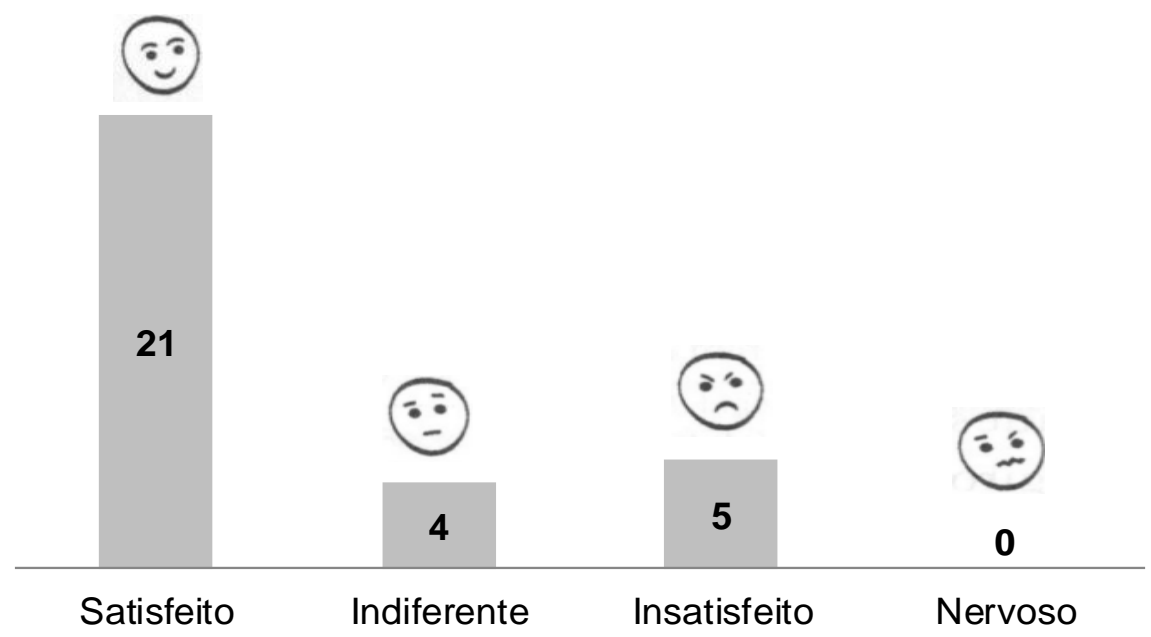

Gráfico 20 - Grau de satisfação dos consumidores que utilizaram o sistema "sem parar" na execução do processo de estacionar o carro.

Os dados obtidos indicam que $67 \%$ dos consumidores que utilizaram o sistema "ticket na catraca" (39 em 58) afirmaram que estavam satisfeitos com o processo, enquanto $70 \%$ dos consumidores que utilizaram o sistema "sem parar" (21 em 30) disseram que estavam satisfeitos.

Nos boxplots do Gráfico 21 e do Gráfico 22 pode se observar a relação da satisfação do consumidor com o tempo gasto para estacionar o carro no sistema "ticket na catraca" e para estacionar o carro no sistema "sem parar", respectivamente. 


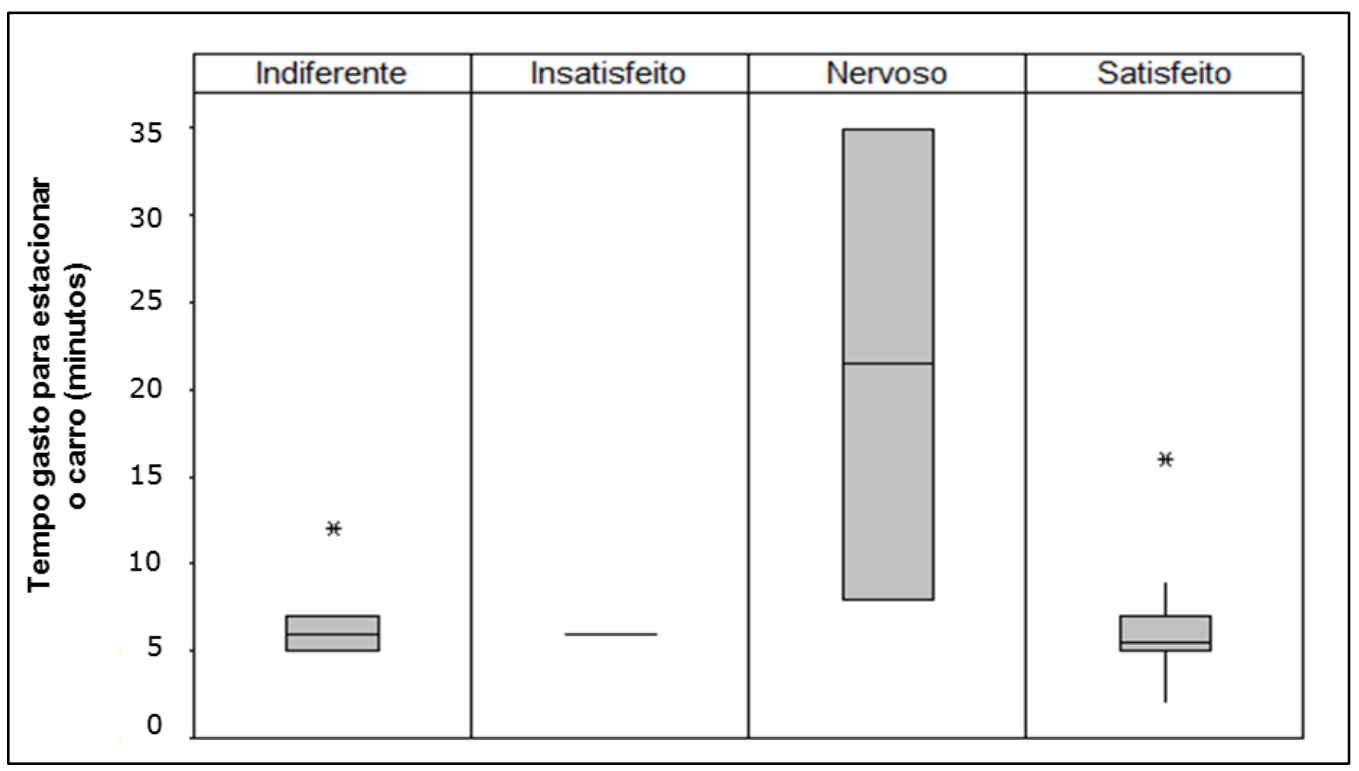

Gráfico 21 - Relação da satisfação do consumidor com o tempo gasto para estacionar o carro no sistema "ticket na catraca"

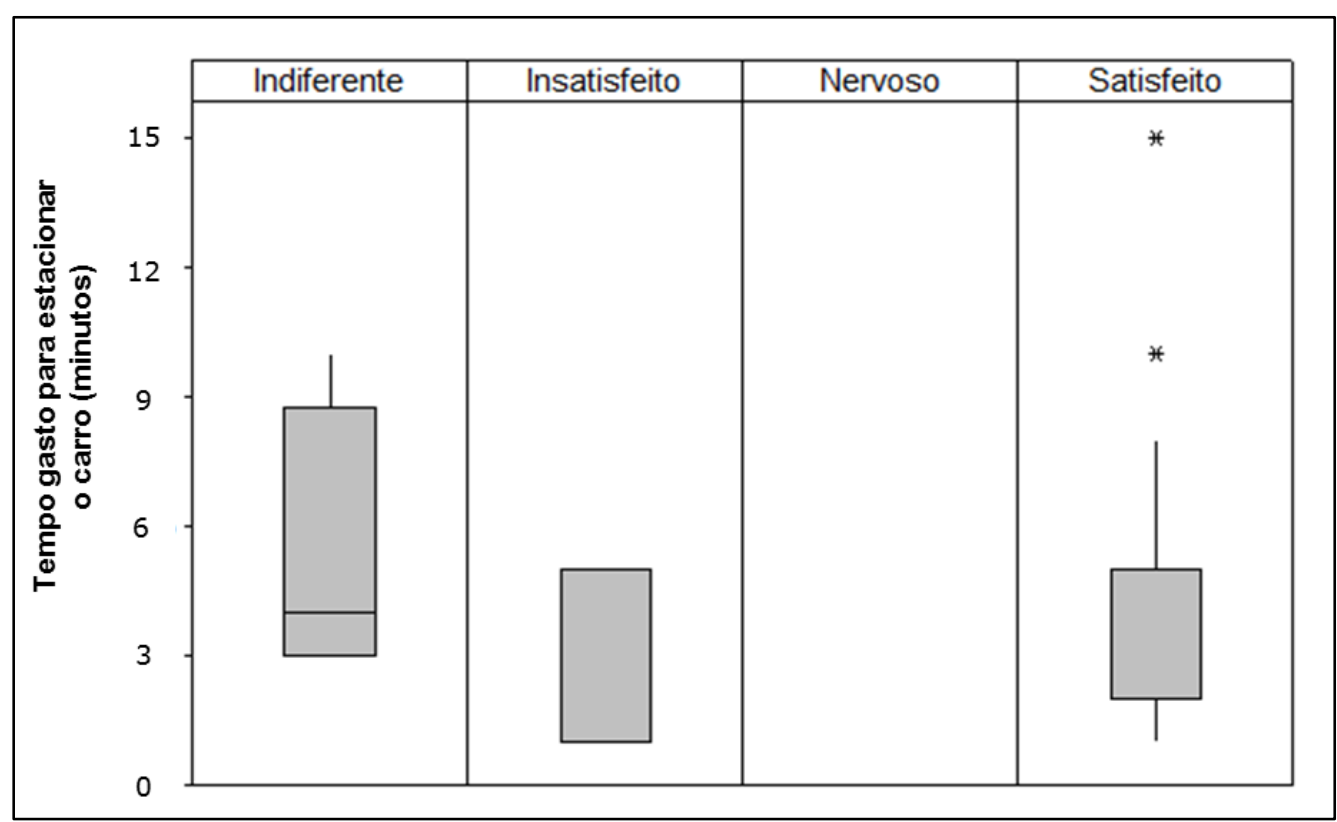

Gráfico 22 - Relação da satisfação do consumidor com o tempo gasto para estacionar o carro no sistema "sem parar" 
A observação do Gráfico 21 chama a atenção ao fato de que as variações de tempo para as categorias satisfeito, indiferente e insatisfeito não apresentaram grande diferença quando comparadas à variação dos tempos gastos para estacionar o carro pelos consumidores que disseram ter ficado nervosos com o processo.

Comentários realizados pelos consumidores que disseram ter ficado nervoso apontaram uma relação direta com o tempo gasto para encontrar uma vaga, expressa por frases como "sempre demoro muito para encontrar uma vaga aqui" e "neste shopping center não existem vagas suficientes". Já nos casos em que o consumidor manifestou insatisfação com o processo de estacionar o carro o motivo não está somente relacionado ao tempo despendido pelo consumidor, mas também ao tamanho das vagas que nem sempre são adequadas para as dimensões do veículo.

O tempo gasto para estacionar o veículo ainda pode ser analisado em relação ao dia da semana. O Gráfico 23 corrobora a suposição dos consumidores em geral de que no final de semana o shopping center está mais cheio do que nos dias úteis. 


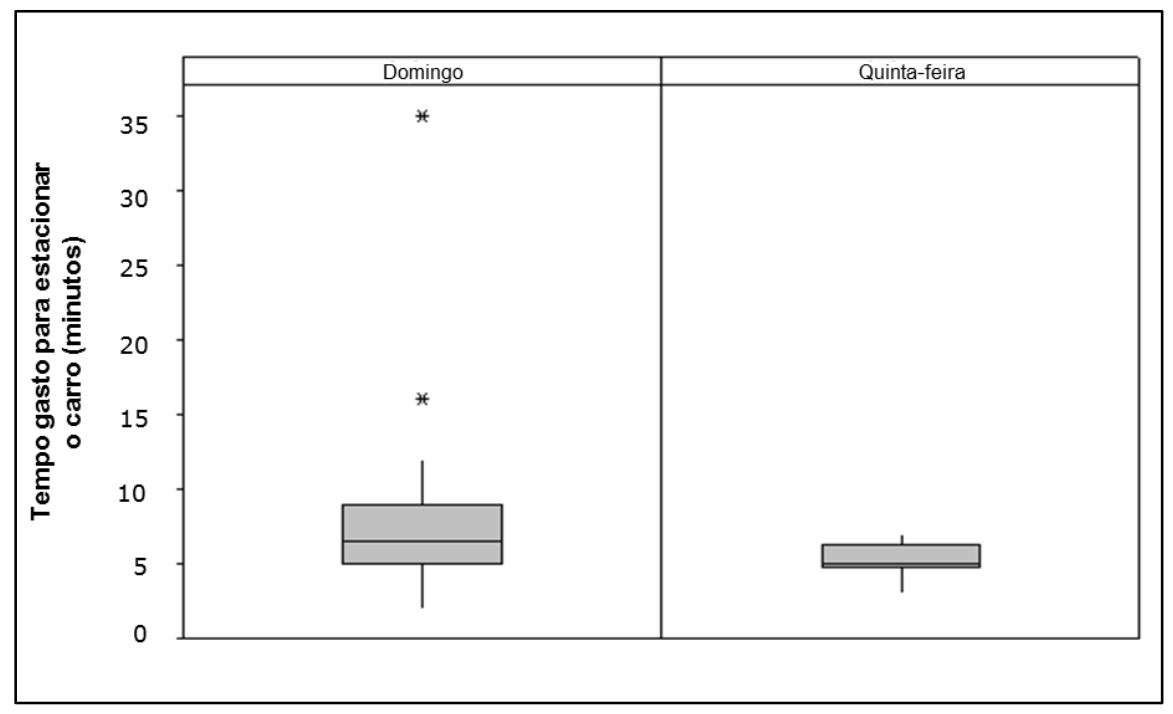

(a) Consumidores que utilizaram o sistema "ticket na catraca"

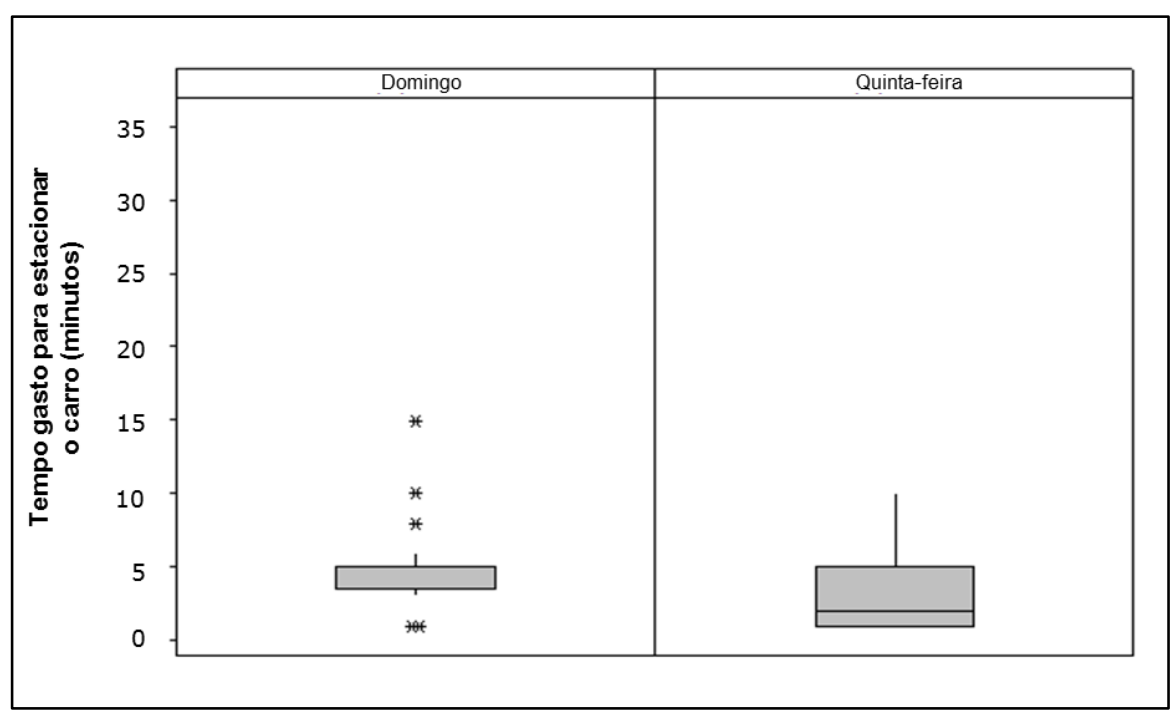

(b) Consumidores que utilizaram o sistema "sem parar"

Gráfico 23 - Tempo gasto pelos consumidores para estacionar no domingo e na quinta-feira

Observa-se que no domingo a mediana dos tempos para se estacionar o carro é maior do que na quinta-feira. Além disso, verifica-se uma variação maior dos tempos coletados no domingo registrando-se inclusive a ocorrência de outliers.

As análises obtidas com os dados complementares, apesar de não estarem associadas à construção do Mapa de Consumo em si, contribuem para a busca de uma melhor compreensão do processo e de suas particularidades. 


\section{DIFICULDADES E PONTOS POSITIVOS IDENTIFICADOS NA CONSTRUÇÃO DO MAPA DE CONSUMO}

Neste capítulo são apontadas as dificuldades e os pontos positivos encontrados no processo de construção dos Mapas de Consumo apresentados nos Capítulos 4 e 5 a fim de esclarecer que dificuldades são encontradas no mapeamento da participação do consumidor no processo de serviço (Q4).

As dificuldades enfrentadas durante a execução deste trabalho advêm não somente do objetivo de mapear e medir as tarefas executadas pelos consumidores para construção do Mapa de Consumo, mas também da conjunção do mesmo com os métodos de pesquisa empregados.

A principal dificuldade encontrada na coleta de dados para mapeamento dos processos "faça você mesmo" dos dois tipos estudados, com interação remota e com interação presencial, foi a baixa adesão dos consumidores abordados na pesquisa, dificuldade que advém do objetivo de mapear e medir as tarefas desempenhadas pelos consumidores. O tempo requerido para coletar dados constitui outro ponto relevante no esforço de construção de Mapas do Consumo, pois dependendo do tipo do processo estudado, dos dados a serem medidos pela empresa provedora do serviço e do método de pesquisa empregado, o processo de coleta pode exigir a dedicação de muito tempo.

\section{1 "FAÇA VOCÊ MESMO" COM INTERAÇÃO REMOTA}

No processo de compra coletiva, "faça você mesmo" com interação remota, foi explorada a aplicação dos métodos de estudo de caso e experimento, os quais são avaliados a seguir. 


\subsubsection{Estudo de Caso}

Conforme verificado na seção 4.2.1 o estudo de caso foi realizado junto a uma empresa provedora do serviço tomado como objeto de estudo a fim de verificar as variáveis do processo que eram controladas pela empresa e que ela poderia disponibilizar para viabilizar a construção do Mapa de Consumo das tarefas executadas por consumidores de seu serviço.

A pesquisadora entrou em contato com quatro empresas do setor de compras coletivas para poder desenvolver o estudo de caso. Destas, duas se dispuseram a participar de uma entrevista para que a pesquisadora pudesse explanar com maiores detalhes o objetivo da pesquisa e quais dados seriam necessários para a realização do estudo. A falta de interesse das próprias empresas em compreender como as tarefas executadas pelos consumidores podem ser mapeadas e medidas constituiu um dos obstáculos que dificultaram a construção de mapas deste tipo.

(i) falta de interesse da empresa provedora do serviço em realizar o mapeamento das tarefas executadas pelo consumidor e não pela empresa

Das duas empresas entrevistadas somente uma possuía os registros necessários para o desenvolvimento do estudo de caso em questão. Uma descrição da outra empresa que não foi selecionada para o desenvolvimento do estudo de caso é apresentada no APÊNDICE B. A empresa selecionada que monitora a realização das tarefas desempenhadas pelos consumidores, a empresa Cupom, utiliza o software Google Analytics para registro de dados como a quantidade de consumidores que finalizam a compra e tempo gasto por eles para executar a compra.

Diante disto, verifica-se uma dificuldade que pode ser enfrentada pelas empresas para a construção de mapas de tarefas executadas pelos consumidores

(ii) necessidade de possuir uma ferramenta adequada que possibilite rastrear as tarefas executadas pelo consumidor num processo de serviço e registrar o tempo gasto pelo mesmo. 
Uma das dificuldades encontradas ao procurar capturar dados por meio da empresa provedora do serviço é realizar a medição do tempo de todas as tarefas executadas pelo consumidor, pois nem todas as tarefas do fluxo podem ser medidas. Com efeito, os consumidores executam algumas tarefas como o recebimento do cupom de desconto em uma conta de e-mail hospedada em outros site da internet, e a impressão do cupom independente do sistema da empresa provedora do serviço.

(iii) inviabilidade do rastreamento e medição de todas as tarefas executadas pelo consumidor durante o processo de serviço.

Outro obstáculo identificado no processo de mapeamento das tarefas do consumidor está associado à falta de controle da empresa provedora do serviço sobre o conhecimento e agilidade do consumidor para executar as tarefas que lhe são delegadas e na condução e término das ações sob o comando do mesmo. Este fator pode impactar a confiabilidade dos dados, pois, ao tentar medir as tarefas desempenhadas pelo consumidor remotamente, não se pode admitir que ele ao acessar o sistema do provedor consiga realizar as tarefas que estão sob sua responsabilidade sem interrupções e finalizar o processo com sucesso.

Assim, ocorrem casos em que o consumidor inicia o fluxo do processo e por algum motivo desconhecido o interrompe e abandona o site de compra com o seu acesso acionado (aberto) e, portanto, deixa o cronômetro de medição do tempo de processo em andamento. Para minimizar este tipo de ocorrência, ou seja, continuar contabilizando o tempo de execução das tarefas do consumidor quando na realidade ele já não está dedicado ao processo, os sites limitam o tempo de espera, isto é, se o consumidor exceder um determinado tempo sem interagir com o site seu acesso expira automaticamente e assim, a contabilização do tempo pela ferramenta Google Analytics é finalizada. Este mecanismo força o consumidor a reiniciar o processo do começo caso pretenda concluir efetivamente uma compra.

(iv) a confiabilidade dos dados coletados é limitada, uma vez que o provedor do serviço não possui controle sobre a realização das tarefas que cabem ao consumidor executar.

No estudo de caso da empresa Cupom, o passo seguinte após a obtenção dos dados por ela monitorados por meio da ferramenta Google Analytics foi o de analisar 
e interpretar os dados que foram disponibilizados. A análise destes dados obtidos de fontes secundárias revelou outro ponto crítico dentro do método de estudo de caso, pois demandou cerca de 19 horas da pesquisadora para seu entendimento, o que representa $56 \%$ do tempo total gasto pela pesquisadora com a execução do estudo de caso, estimado em 34 horas. As dúvidas em relação às nomenclaturas utilizadas na base de dados exigiu da pesquisadora a realização de contatos adicionais com a empresa estudada em busca de esclarecimentos que possibilitassem assegurar análises mais consistentes do processo.

(v) necessidade de dedicar tempo para o entendimento dos dados secundários obtidos junto à empresa provedora do serviço para poder proceder sua análise.

Apesar das dificuldades enfrentadas no método estudo de caso, os resultados obtidos possibilitaram a obtenção de um Mapa de Consumo que incorpora, ainda que parcialmente, os aspectos fundamentais prescritos no modelo de representação proposto por Womack e Jones (2006).

Destacam-se, adicionalmente, dois importantes pontos positivos da adoção deste método. Primeiramente, o estudo de caso possibilitou captar a visão e interesse de empresas provedoras do serviço objeto de estudo em rastrear e analisar as tarefas executadas pelos consumidores durante o processo de serviço. Além disso, os relatórios disponibilizados pela empresa, com base no monitoramento dos acessos ao seu site via ferramenta Google Analytics, forneceram uma extensa base de dados para a extração de dados necessários ao detalhamento do Mapa de Consumo que se pretendia construir.

\subsubsection{Experimento}

O estudo acerca da viabilidade de construção e aplicação do Mapa de Consumo para serviços do tipo "faça você mesmo" com interação remota explorou também abordagem de recorrer ao engajamento do consumidor no papel de coletor de dados por meio da realização de um experimento real. 
O tempo e esforço dedicados à construção da planilha apresentada no APÊNDICE C que foi elaborada para facilitar a coleta de dados de forma remota e descentralizada pelos consumidores foi o primeiro obstáculo enfrentado na aplicação desta abordagem que demandou o investimento de 45 horas da pesquisadora em um total de dedicação estimado em 55 horas para realizar as atividades associadas ao experimento.

(vi) necessidade de planejar e desenvolver um instrumento de coleta de dados para viabilizar a condução do experimento e facilitar o registro de dados.

O objetivo da criação e disponibilização desta planilha foi o de assegurar uma coleta de dados para alimentar a construção do mapa de processo das tarefas dos consumidores de forma padronizada e consistente, requerendo o mínimo esforço e tempo do consumidor para sua compreensão e preenchimento.

Apesar da planilha fornecida aos consumidores para apoiar a coleta dos dados referentes aos processos de compra coletiva que executassem ter sido desenvolvida com o propósito de facilitar seu preenchimento, somente $30 \%$ dos consumidores abordados contribuíram com a pesquisa retornando a planilha com os dados preenchidos. Desta forma, constatou-se que uma séria dificuldade enfrentada na realização de um experimento que dependa da colaboração dos consumidores é a

(vii) dificuldade em conquistar a adesão dos consumidores para colaborarem com a pesquisa preenchendo e retornando a planilha de coleta de dados.

Após a coleta dos dados por meio do método experimento passou-se à fase de análise dos dados e construção do Mapa de Consumo. Em comparação ao processo de coleta de dados por meio de um estudo de caso, esta fase de consolidação, análise e interpretação dos dados não foi tão demandante de tempo e esforço, pois os dados foram preenchidos em campos que haviam sido previamente definidos pela pesquisadora e não capturados por meio de uma ferramenta desenvolvida por terceiros, como o Google Analytics.

A aplicação da abordagem de coleta de dados primários via experimento apresentou aspectos positivos uma vez que possibilitou a captura de informações complementares sobre a experiência do consumidor que não puderam ser obtidas 
no estudo de caso. Os dados coletados por meio do experimento possibilitaram estimar as frações do tempo gasto pelo consumidor na execução de tarefas em que houve agregação de valor e em que não houve agregação de valor. Ademais, este método possibilita avaliar o processo diretamente sob a perspectiva do consumidor quando este é o executor do processo.

As principais dificuldades enfrentadas e os aspectos positivos identificados na aplicação de cada um dos métodos de pesquisa adotados para o mapeamento da participação do consumidor em um processo de serviço de compra coletiva, tomado como exemplo de serviço do tipo "faça você mesmo" com interação remota, são resumidos na Tabela 11.

Tabela 11- Dificuldades e aspectos positivos identificados na aplicação dos métodos de pesquisa considerados para mapeamento do processo do tipo "faça você mesmo" com interação remota

\begin{tabular}{|c|c|c|c|}
\hline \multirow[b]{2}{*}{$\begin{array}{l}\text { Método de } \\
\text { pesquisa } \\
\\
\text { Estudo de Caso: } \\
\text { - busca de dados } \\
\text { junto à empresa } \\
\text { provedora do } \\
\text { serviço estudado } \\
\text { - aproveitamento } \\
\text { de dados } \\
\text { secundários } \\
\text { definidos por } \\
\text { terceiros }\end{array}$} & \multicolumn{2}{|c|}{ Dificuldades enfrentadas } & Pontos positivos \\
\hline & (iv) & $\begin{array}{l}\text { falta de interesse da empresa } \\
\text { provedora do serviço em realizar o } \\
\text { mapeamento das tarefas } \\
\text { executadas pelo consumidor e não } \\
\text { pela empresa } \\
\text { necessidade de possuir uma } \\
\text { ferramenta adequada que possibilite } \\
\text { rastrear as tarefas executadas pelo } \\
\text { consumidor num processo de } \\
\text { serviço e registrar o tempo gasto } \\
\text { pelo mesmo } \\
\text { inviabilidade do rastreamento e } \\
\text { medição de todas as tarefas } \\
\text { executadas pelo consumidor } \\
\text { durante o processo de serviço } \\
\text { a confiabilidade dos dados } \\
\text { coletados é limitada, uma vez que o } \\
\text { provedor do serviço não possui } \\
\text { controle sobre a realização das } \\
\text { tarefas que cabem ao consumidor } \\
\text { executar } \\
\text { necessidade de dedicar tempo para } \\
\text { o claro entendimento dos dados } \\
\text { secundários obtidos junto à } \\
\text { empresa provedora do serviço para } \\
\text { poder preceder sua análise }\end{array}$ & $\begin{array}{l}\text { - Captar a visão e interesse } \\
\text { das empresas provedoras } \\
\text { do serviço em rastrear e } \\
\text { analisar as tarefas } \\
\text { executadas pelos } \\
\text { consumidores } \\
\text { - A adoção de ferramentas } \\
\text { como Google Analytics } \\
\text { proporciona uma extensa } \\
\text { base de dados relevantes } \\
\text { para construção do Mapa de } \\
\text { Consumo }\end{array}$ \\
\hline
\end{tabular}




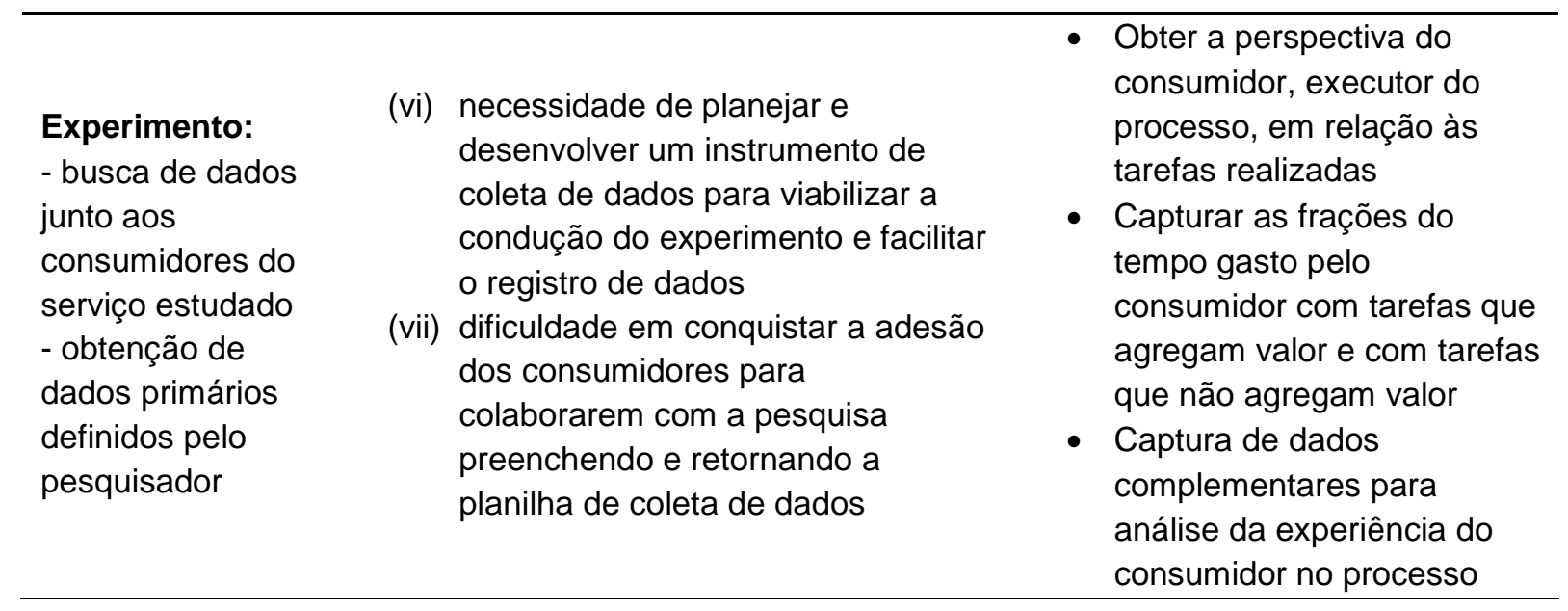

\section{2 "FAÇA VOCÊ MESMO" COM INTERAÇÃO PRESENCIAL}

O processo de construção do Mapa de Consumo para o serviço do tipo "faça você mesmo" com interação presencial foi estudado tomando o processo de estacionar o carro em um shopping center como objeto de estudo. O método de pesquisa utilizado para coletar dados sobre a participação do consumidor, conforme explicitado na seção 3.2 , foi a enquete.

\subsubsection{Enquete}

Para a aplicação deste método de pesquisa foi estruturado o formulário apresentado no APÊNDICE E para registro dos dados obtidos pela pesquisadora junto aos consumidores. Uma dificuldade inicial enfrentada para poder conduzir este método de pesquisa foi determinar quais dados seriam capturados na enquete $e$, consequentemente, quais perguntas seriam direcionadas aos consumidores. Nesta fase de planejamento foi necessário definir como a abordagem seria realizada junto aos consumidores para medir o tempo por eles gasto no processo de estacionar o veículo e captar seu grau de satisfação em relação às tarefas que teve de executar. 
(i) definição dos dados a serem coletados na enquete e da forma de captura do tempo gasto pelo consumidor para executar o processo, e do seu grau de satisfação em relação às tarefas realizadas

A parte operacional de estruturação do formulário não demandou dedicação de uma quantidade de tempo considerável pela pesquisadora quando comparado ao tempo que foi necessário dedicar para elaborar a planilha eletrônica que teve de ser utilizada para facilitar a coleta de dados na condução do experimento do serviço "faça você mesmo" com interação remota junto aos consumidores.

A execução da enquete, diferentemente do que ocorreu na aplicação dos métodos de estudo de caso e experimento, exigiu que a pesquisadora se deslocasse até o local da empresa provedora do serviço onde o processo estudado é executado pelo consumidor. O tempo total estimado da pesquisadora para realização da enquete é de 25 horas, das quais 7 horas destinaram-se a fase de coleta de dados para deslocamento e execução das entrevistas. Os consumidores entrevistados foram abordados presencialmente para que respondessem às perguntas formuladas diretamente pela pesquisadora.

(ii) necessidade de deslocamento da pesquisadora até o local onde 0 processo de serviço a ser estudado é realizado e de dedicação de tempo para execução da enquete

Durante a abordagem dos consumidores, algumas pessoas se recusaram a participar da pesquisa. $\mathrm{Na}$ enquete realizada no domingo $79 \%$ dos consumidores aceitaram participar da pesquisa, enquanto na quinta-feira o percentual de adesão foi de $54 \%$.

(iii) dificuldade de conquistar a adesão dos consumidores abordados à solicitação para participar da enquete

A necessidade de contar com a disposição dos consumidores em responder as perguntas da enquete constitui uma dificuldade para a aplicação deste método de pesquisa. Contudo, o percentual dos consumidores que aderiram à enquete, sendo este $68 \%$ (ver seção 5.2.1.2), foi maior se comparado ao percentual de $30 \%$ dos consumidores contatados que aceitaram colaborar no experimento desenvolvido 
para o serviço "faça você mesmo" com interação remota (ver seção 4.2.2). Este é um aspecto muito relevante a ser considerado para a adoção desta forma de coleta de dados, uma vez que seu sucesso depende da disposição do consumidor em colaborar com a pesquisa.

Por outro lado, a abordagem de buscar dados necessários à construção do Mapa de Consumo, junto aos consumidores, realizando uma enquete presencialmente revela pontos positivos relevantes.

O método da enquete permite verificar diretamente a percepção do consumidor quanto às tarefas que teve de executar no processo. Por ser aplicada presencialmente, esta abordagem permite à pesquisadora apreender o grau de satisfação demonstrado pelo consumidor em relação ao processo e obter comentários que justifiquem sua percepção. Isso não é possível de fazer no serviço do tipo "faça você mesmo" com interação remota em que o consumidor não executa no ambiente do provedor as tarefas sob seu encargo.

$\mathrm{Na}$ Tabela 12 é apresentado um resumo das principais dificuldades e aspectos positivos identificados na aplicação do método de pesquisa da enquete para o processo de estacionar o carro em um shopping center.

Tabela 12 - Dificuldades e aspectos positivos identificados na aplicação do método de pesquisa da enquete para mapeamento do processo do tipo "faça você mesmo" com interação presencial

\begin{tabular}{|c|c|c|}
\hline $\begin{array}{l}\text { Método de } \\
\text { pesquisa }\end{array}$ & Dificuldades enfrentadas & Pontos positivos \\
\hline $\begin{array}{l}\text { Enquete: } \\
\text { - busca de dados } \\
\text { junto aos } \\
\text { consumidores do } \\
\text { serviço estudado } \\
\text { com interação } \\
\text { presencial } \\
\text { - obtenção de } \\
\text { dados primários } \\
\text { definidos pelo } \\
\text { pesquisador }\end{array}$ & $\begin{array}{l}\text { definição dos dados a serem } \\
\text { coletados na enquete e da } \\
\text { forma de captura do tempo } \\
\text { gasto pelo consumidor para } \\
\text { executar o processo, e do seu } \\
\text { grau de satisfação em relação } \\
\text { às tarefas realizadas } \\
\text { necessidade de deslocamento } \\
\text { da pesquisadora até o local } \\
\text { onde o processo de serviço a } \\
\text { ser estudado é realizado e de } \\
\text { dedicação de tempo para } \\
\text { execução da enquete }\end{array}$ & $\begin{array}{l}\text { - Obter a perspectiva do } \\
\text { consumidor em relação às } \\
\text { tarefas por ele realizadas no } \\
\text { processo } \\
\text { - Capturar o grau de satisfação } \\
\text { do consumidor em relação às } \\
\text { tarefas executadas } \\
\text { - Capturar, presencialmente, } \\
\text { detalhes do processo e o } \\
\text { motivo da satisfação ou } \\
\text { insatisfação do consumidor } \\
\text { em relação ao processo }\end{array}$ \\
\hline
\end{tabular}



(iii) dificuldade de conquistar a adesão dos consumidores abordados à solicitação para participar da enquete

Conforme se pode verificar, os métodos adotados para alimentar o processo de construção do Mapa de Consumo que foram explorados nos Capítulos 4 e 5 apresentam cada qual vantagens e dificuldades. Apesar das dificuldades práticas apontadas neste capítulo à construção de mapas que representem a execução de tarefas por consumidores como o Mapa de Consumo mostrou-se válida e exequível desde que métodos de coleta de dados pertinentes sejam selecionados e aplicados para se obter as informações requeridas. 


\section{CONCLUSÕES}

Neste capítulo, pretende-se avaliar a pesquisa desenvolvida neste estudo, resgatando os objetivos e questões de pesquisa propostos e relacionando-os aos levantamentos e análises desenvolvidas no decorrer do trabalho. Além de enunciar as principais conclusões do trabalho, pretende-se apontar suas limitações e sugerir possíveis extensões a pesquisa desenvolvida sobre o tema em foco.

\subsection{CONCLUSÕES DECORRENTES DAS QUESTÕES DE PESQUISA}

Este trabalho se propôs a estudar as ferramentas de mapeamento de processos que poderiam ser aplicadas para a visualização da participação do consumidor em processos de consumo de serviço, conforme o objetivo explicitado no Capítulo 1.

Primeiramente, com base em pesquisa bibliográfica, foi realizado um levantamento das ferramentas de mapeamento de processos que podem ser utilizadas na construção de mapas que descrevam as tarefas desempenhadas pelos consumidores em processos de consumo de serviço. Esta forma de aplicação das ferramentas de mapeamento faz-se necessária, quando o consumidor é um agente que participa dos processos de serviço atuando como coprodutor.

Com base na revisão da literatura, o SIPOC, Blueprint, Mapa de Consumo, SERVPRO e Carta de Atividades foram pormenorizados como possíveis ferramentas que poderiam ser aplicadas na análise da participação do consumidor em processos de serviço.

As ferramentas de mapeamento estudadas possuem características próprias que foram enumeradas na seção 2.1. Posteriormente, na seção 2.1.6, efetuou-se uma análise comparativa das ferramentas de forma a destacar as principais características de cada uma delas e assim esclarecer como a literatura propõe a construção de mapas para visualizar as atividades executadas pelos 
consumidores nos processos de serviço, que é o ponto focado pela primeira questão de pesquisa (Q1) proposta.

A revisão da literatura apresentou, adicionalmente, duas ferramentas de mapeamento do processo, quais sejam a Cadeia de Valor do Consumidor e a Rede de Relacionamento, que também podem servir para a visualização do papel do consumidor na execução de um processo. Estas ferramentas não permitem visualizar o processo em um fluxo sequencial de atividades, mas evidenciam o papel do consumidor e demais pessoas envolvidas na prestação do serviço considerado.

Após a revisão da literatura este trabalho abordou o processo de construção do Mapa de Consumo explorando a questão de como mapear as tarefas realizadas pelos consumidores durante o processo de serviço (Q2), nos Capítulos 4 e 5 . O estudo do processo de construção do Mapa de Consumo, considerando a participação do consumidor num processo de serviço real desenvolvido nos Capítulos 4 e 5, tratou também da questão de como medir o esforço e a satisfação dos consumidores nas tarefas por eles desempenhadas durante o processo de serviço (Q3).

A segunda (Q2) e terceira (Q3) questões de pesquisa foram tratadas neste trabalho com a pesquisadora colocando-se na posição de um analista que pretende representar e analisar a participação de consumidores em processos de serviço reais. O processo de construção do Mapa de Consumo foi conduzido em dois casos reais de serviço, nos quais o consumidor exerce papel fundamental na execução do processo. Conforme delimitado no escopo do presente trabalho o estudo, se restringiu aos serviços do tipo "faça você mesmo".

O processo de construção do Mapa de Consumo teve de ser delimitado mais especificamente aos serviços da categoria "faça você mesmo" com interação remota e com interação presencial com o intuito de minimizar interferências no fluxo do processo e na satisfação do consumidor que poderiam ser causadas por funcionários da empresa prestadora do serviço que interagissem com o consumidor durante o processo.

Outra delimitação assumida neste estudo foi considerar casos práticos que apresentam um processo único, ou seja, nos quais não ocorrem ramificações no 
fluxo e existe um padrão na sequência de tarefas. Desta forma, pretendeu-se verificar a viabilidade de aplicação da ferramenta Mapa de Consumo para processos simples com uma sequencia única de etapas que não estão sujeitos à complexidade e dificuldades causadas pela variabilidade na sua execução.

Respeitando tais delimitações, foram selecionados dois processos reais com o intuito de avaliar como as tarefas realizadas pelos consumidores durante o processo de serviço podem ser mapeadas e como se pode medir o esforço e a satisfação dos consumidores quanto às tarefas desempenhadas por estes.

O primeiro caso estudado foi o do serviço de compra coletiva realizado pelo consumidor via internet, exemplificando o tipo de serviço "faça você mesmo" com interação remota. Para este tipo de serviço foram considerados dois métodos de coleta de dados: o estudo de caso e o experimento. O segundo serviço selecionado como objeto de estudo foi o processo de estacionar o carro em um shopping center. Por meio deste exemplo pretendeu-se avaliar a aplicabilidade da ferramenta Mapa de Consumo para os serviços do tipo "faça você mesmo" com interação presencial.

O serviço "faça você mesmo" com interação remota considerou como possíveis fontes de dados para construção do Mapa de Consumo a empresa provedora do serviço e o consumidor. Para avaliação da empresa como fonte de dados foi realizado um estudo de caso único, em que, por meio de entrevistas e do acesso à base de dados da empresa, pode-se coletar dados relevantes à construção do Mapa de Consumo. A realização do experimento, por outro lado, visou recorrer ao consumidor como fonte de dados. Para viabilizar a condução do experimento foi necessário desenvolver uma planilha eletrônica para facilitar o preenchimento de dados pelo consumidor durante a execução de suas compras.

Na Tabela 13 são apresentadas as fontes de dados utilizadas e os tipos de dados coletados nos métodos de pesquisa explorados no estudo do processo de compra coletiva que exemplifica os serviços do tipo "faça você mesmo" com interação remota. 
Tabela 13 - Fontes de dados adotadas para o processo do tipo "faça você mesmo" com interação remota e dados coletados

\begin{tabular}{|c|c|c|}
\hline $\begin{array}{l}\text { Método de } \\
\text { pesquisa }\end{array}$ & Fontes de dados & Dados coletados \\
\hline $\begin{array}{l}\text { Estudo de Caso } \\
\text { e Experimento }\end{array}$ & $\begin{array}{l}\text { Observação direta } \\
\text { do processo pela } \\
\text { própria } \\
\text { pesquisadora }\end{array}$ & $\begin{array}{l}\text { - Fluxo básico do processo } \\
\text { - Ramificações do processo } \\
\text { - Definição dos tópicos a serem abordados na } \\
\text { entrevista com a empresa } \\
\text { - Pontos de medição para estruturação da planilha de } \\
\text { coleta de dados para o experimento }\end{array}$ \\
\hline \multirow{2}{*}{ Estudo de Caso } & $\begin{array}{l}\text { Entrevista com } \\
\text { empresa provedora } \\
\text { do serviço }\end{array}$ & $\begin{array}{l}\text { - Mapa detalhado do processo } \\
\text { - Ramificações do processo } \\
\text { - Preocupação da empresa no desenvolvimento de um } \\
\text { site adequado para apoiar a execução das tarefas } \\
\text { dos consumidores }\end{array}$ \\
\hline & $\begin{array}{l}\text { Relatórios da } \\
\text { empresa (gerados } \\
\text { pela ferramenta } \\
\text { Google Analytics) }\end{array}$ & $\begin{array}{l}\text { - Tempo gasto pelos consumidores para executar } \\
\text { tarefas do processo } \\
\text { - Taxa de rejeição dos clientes (clientes que não } \\
\text { finalizam a compra) } \\
\text { - Dados para análises complementares }\end{array}$ \\
\hline Experimento & $\begin{array}{l}\text { Coleta de dados } \\
\text { com a colaboração } \\
\text { de consumidores } \\
\text { por meio do } \\
\text { preenchimento de } \\
\text { uma planilha } \\
\text { eletrônica }\end{array}$ & $\begin{array}{l}\text { - Tempo gasto pelos consumidores para executar as } \\
\text { tarefas do processo } \\
\text { - Identificação de variações/ desperdícios no processo } \\
\text { (parcelas do tempo dedicado ao processo em que } \\
\text { houve e não houve agregação de valor) } \\
\text { - Identificação de problemas enfrentados pelos } \\
\text { consumidores } \\
\text { - Dados para análises complementares }\end{array}$ \\
\hline
\end{tabular}

Os métodos de estudo de caso e experimento aplicados para coleta de dados do serviço do tipo "faça você mesmo" com interação remota permitiram concluir que tanto a empresa como o consumidor podem servir como fontes de dados que ajudam a viabilizar a construção do Mapa de Consumo. Entretanto, em ambos os casos os Mapas de Consumo resultantes das informações obtidas não foram totalmente aderentes ao modelo de representação estabelecido por Womack e Jones (2006). Apesar disso, os mapas construídos possibilitaram uma visualização 
clara das tarefas desempenhadas pelos consumidores. Ademais, foi possível verificar que os dados coletados poderiam servir de insumo para análises relevantes para a melhoria do processo.

Por meio dos dados do estudo de caso e do experimento pode-se, ainda, construir um Mapa de Consumo combinando dados levantados junto à empresa e aos consumidores. Verificou-se que a versão do mapa assim consolidado é mais completa do que os mapas construídos considerando somente dados fornecidos pela empresa ou pelos consumidores. Porém, esta versão do mapa baseada em dados consolidados também não aderiu totalmente ao modelo de representação estabelecido por Womack e Jones (2006), pois não informa o grau de satisfação dos consumidores em relação às tarefas executadas.

O segundo exemplo prático abordado por esta pesquisa refere-se ao processo de estacionar o carro em um shopping center e trata-se de um processo do tipo "faça você mesmo" com interação presencial. Neste processo, apesar do consumidor estar no ambiente físico do provedor do serviço as tarefas são realizadas inteiramente pelo consumidor.

O método de pesquisa adotado para coletar dados necessários à construção do Mapa de Consumo referente a este processo foi a enquete tendo o consumidor como a única fonte de dados. Diferentemente do que ocorre no processo com interação remota (em que o consumidor executa o processo fora do ambiente físico do provedor, estando na sua casa, no seu trabalho ou em qualquer outro lugar), nos processos com interação presencial, pelo fato do consumidor executar o processo no ambiente físico do provedor, é possível observá-lo diretamente no local onde o processo ocorre. Pelo mesmo motivo, é também viável abordar o cliente para aplicação da enquete logo após a execução deste processo de serviço. A Tabela 14 apresenta os dados que foram coletados na enquete abordando os consumidores do processo. 
Tabela 14- Fonte de dados adotada para o processo do tipo "faça você mesmo" com interação presencial e dados coletados

\begin{tabular}{|c|c|c|}
\hline $\begin{array}{l}\text { Método de } \\
\text { pesquisa }\end{array}$ & Fonte de dados & Dados coletados \\
\hline Enquete & $\begin{array}{l}\text { Entrevista } \\
\text { presencial com o } \\
\text { consumidor }\end{array}$ & $\begin{array}{l}\text { - Horário de início do processo } \\
\text { - Horário de finalização do processo } \\
\text { - Tempo gasto pelos consumidores para executar as } \\
\text { tarefas do processo } \\
\text { - Identificação de variações/ desperdícios no processo } \\
\text { (parcelas do tempo dedicado ao processo em que } \\
\text { houve e não houve agregação de valor) } \\
\text { - Identificação de problemas enfrentados pelos } \\
\text { consumidores } \\
\text { - Grau de satisfação do consumidor em executar o } \\
\text { processo } \\
\text { - Dados para análises complementares }\end{array}$ \\
\hline
\end{tabular}

Os dados coletados permitiram construir o Mapa de Consumo do processo de estacionar o carro em um shopping center. $\mathrm{O}$ método da enquete aplicado para o tipo de serviço "faça você mesmo" com interação presencial apresentou vantagens quando comparado aos métodos do estudo de caso e experimento. A realização da enquete permitiu capturar o grau de satisfação geral do consumidor em relação ao processo realizado, além dos dados de tempo gasto para executar o processo e estimativas para a fração do tempo dedicado ao processo em que houve e não houve agregação de valor, também obtidos pelos métodos de estudo de caso e experimento.

Outra questão abordada neste estudo foi direcionada à identificação das principais dificuldades encontradas no mapeamento da participação do consumidor no processo de serviço (Q4).

A principal dificuldade enfrentada refere-se à necessidade de contar com a adesão das partes contatadas à pesquisa. No estudo de caso, uma das dificuldades foi encontrar uma empresa interessada em entender a perspectiva do consumidor em relação ao processo de compra coletiva e que possuísse meios para tentar rastrear as tarefas executadas pelo consumidor em interação com seu site. Nos métodos que 
utilizaram o consumidor como fonte de dados, quais sejam, experimento e enquete, também se enfrentou a dificuldade de contar com a adesão dos consumidores à pesquisa.

$\mathrm{Na}$ aplicação do experimento obteve-se uma adesão de $30 \%$ dos consumidores, ou seja, a maior parte dos consumidores abordados não se dispôs a preencher a planilha para medir o tempo gasto com nas tarefas do processo de compra coletiva focado. Na enquete obteve-se uma adesão significativamente maior que a alcançada na realização do experimento, sendo que, $68 \%$ dos consumidores se dispuseram a participar da pesquisa e responder as questões da enquete presencial.

Entre as outras dificuldades enfrentadas durante o desenvolvimento deste trabalho vale destacar o tempo gasto pela pesquisadora com a elaboração da planilha para a coleta de dados do experimento e para a análise e interpretação dos dados coletados junto à empresa provedora do serviço durante o estudo de caso.

Vale ressaltar que cada um dos métodos de pesquisa adotados também revelaram aspectos positivos para sua aplicação. Um ponto positivo observado na coleta de dados junto à empresa provedora do serviço foi poder extrair dados a partir de uma base de dados da empresa, utilizando o software Google Analytics. Ao utilizar esta fonte, torna-se possível obter uma grande quantidade de dados para construção e análise do Mapa de Consumo, sem que os consumidores percebam ou tenham suas tarefas impactadas com isto.

A aplicação do método de pesquisa do experimento, por sua vez, possibilitou levantar dados a respeito de desvios e desperdícios do processo, ainda que de forma qualitativa, diretamente do consumidor, num processo em que este desempenha o papel de principal executor num local remoto ao provedor e à pesquisadora.

Quanto ao desenvolvimento da enquete vale destacar que a realização de entrevistas presenciais com os consumidores foi o único método que possibilitou à pesquisadora questionar o grau de satisfação geral dos mesmos em relação às tarefas que teve de executar e capturar sua reação. 
Os levantamentos e análises realizados nesta pesquisa permitem concluir que a construção e aplicação do Mapa de Consumo para os processos de serviço do tipo "faça você mesmo", tanto na modalidade com interação remota como na modalidade com interação presencial são viáveis. Cabe salientar que os mapas que puderam ser construídos não aderiram plenamente a todos os aspectos do modelo de representação proposto por Womack e Jones (2006), conforme resume a Tabela 15. Contudo, o processo de construção destes mapas possibilitou visualizar o fluxo das tarefas executadas pelos consumidores e caracterizar ainda que parcialmente o esforço e tempo que precisam ser dedicados pelos mesmos para a concretização serviço.

Tabela 15 - Viabilidade de aplicação da ferramenta Mapa de Consumo

\begin{tabular}{ccccccc}
\hline & & \multicolumn{2}{c}{ Aspectos do modelo de representação do Mapa de Consumo proposto } \\
por Womack e Jones (2006)
\end{tabular}

Não foi possível obter nenhuma versão do Mapa de Consumo que incorporasse todos os aspectos gráficos e informativos que caracterizam o modelo de representação proposto por Womack e Jones (2006). A versão obtida baseada no método de levantamento de dados por meio de enquete foi a que mais se aproximou da forma de representação ideal do Mapa de Consumo.

Cabe salientar que a ferramenta Mapa de Consumo, apesar de ser a ferramenta estudada que apresentou maior aderência às características estudadas em relação ao mapeamento das tarefas desempenhadas pelos consumidores, não consegue 
retratar outros aspectos importantes associados aos processos de serviço. Aspectos como o esforço mental e o esforço físico demandados do consumidor para execução das tarefas poderiam ser adicionalmente contempladas na caracterização do fluxo das tarefas desempenhadas pelo consumidor. Ademais, uma ferramenta que possibilitasse uma comparação entre o tempo real gasto pelo consumidor e o tempo percebido poderia contribuir para o entendimento da visão do consumidor sob o processo de consumo do serviço.

Os processos de serviço apresentam singularidades que em uma análise mais detalhada podem resultar em um mapa específico à experiência de cada consumidor evidenciando a heterogeneidade que é intrínseca aos processos de consumo de serviços. A comparação de diversos mapas singulares assim obtidos permitiria analisar como a heterogeneidade impacta o fluxo de serviço.

Um aspecto relacionado aos procedimentos de coleta de dados aplicados nos métodos de pesquisa selecionados é a quantidade de tempo que demanda do pesquisador (analista). Os tempos gastos pela pesquisadora no esforço de levantamento de dados para a construção do Mapa de Consumo com base nas abordagens de realização de um estudo de caso, experimento e enquete, são apresentados na Tabela 16, estimados em horas.

Tabela 16 - Tempo dedicado pela pesquisadora para mapeamento da participação do consumidor

\begin{tabular}{|c|c|c|c|}
\hline \multirow{2}{*}{$\begin{array}{l}\text { Atividades realizadas } \\
\text { (estimativa em horas) }\end{array}$} & \multicolumn{2}{|c|}{$\begin{array}{l}\text { "Faça você mesmo" com } \\
\text { interação remota }\end{array}$} & \multirow{2}{*}{$\begin{array}{c}\begin{array}{c}\text { "Faça você mesmo" com } \\
\text { interação presencial }\end{array} \\
\text { Enquete }\end{array}$} \\
\hline & Estudo de Caso & Experimento & \\
\hline $\begin{array}{l}\text { Planejamento e obtenção do } \\
\text { caso para estudo }\end{array}$ & 8 & 45 & 5 \\
\hline Coleta de dados & 19 & 1 & 7 \\
\hline $\begin{array}{l}\text { Organização/ consolidação } \\
\text { de dados }\end{array}$ & 5 & 3 & 7 \\
\hline $\begin{array}{l}\text { Construção do Mapa de } \\
\text { Consumo }\end{array}$ & 2 & 3 & 3 \\
\hline Análises complementares & 0 & 3 & 3 \\
\hline Totais & 34 & 55 & 25 \\
\hline
\end{tabular}


Como se pode observar na Tabela 16 a atividade que demandou maior tempo da pesquisadora foi o planejamento e obtenção do caso para realização do experimento (45 horas). Boa parte deste tempo foi dedicada à construção da planilha eletrônica utilizada para coleta de dados junto aos consumidores. O método do estudo de caso, por outro lado, exigiu maior dedicação de tempo à atividade de coleta de dados (19 horas), durante a qual a pesquisadora acessou a ferramenta Google Analytics e capturou os dados necessários para estruturação do Mapa de Consumo do processo de compra coletiva. Já o método da enquete foi o que exigiu menor tempo total de dedicação (25 horas).

A análise dos tempos de dedicação exigidos da pesquisadora revela que mesmo tratando-se do esforço de mapeamento de um processo com fluxo único, padronizado e com poucas ramificações, a construção de um Mapa de Consumo exigiu uma substancial quantidade de horas. Com base nestes dados empíricos, é possível admitir que para processos mais complexos que apresentem fluxos com ramificações e para processos nos quais o consumidor interage com os funcionários da empresa prestadora do serviço, a construção do Mapa de Consumo seja ainda mais complexa e demande mais horas de dedicação o que pode desencorajar a realização de iniciativas de mapeamento do fluxo de tarefas que cabe ao consumidor executar.

Conclui-se, ademais, que embora o trabalho tenha se limitado a explorar a viabilidade de mapeamento da participação do consumidor em processos de serviço com foco na ferramenta do Mapa de Consumo, os pontos centrais verificados são também válidos ao processo de mapeamento adotando as demais ferramentas identificadas na revisão da literatura (Q1), pois:

- Os métodos de coleta de dados aplicados podem ser estendidos à construção de mapas similares por meio das demais ferramentas;

- Em termos de conteúdo, conforme resume a Tabela 4, o Mapa de Consumo é a alternativa de ferramenta mais abrangente, ou seja, aquela que descreve o maior número de aspectos da participação do consumidor em processos de serviço e, em geral, com grau de detalhe comparativamente maior. Isso faz com que o Mapa de Consumo seja o mais complexo de ser construído dentre as ferramentas consideradas. Assim, o que esta pesquisa evidenciou ser 
viável operacionalizar na construção do Mapa de Consumo no tratamento das questões Q2 e Q3, também pode ser estendido ao mapeamento do consumidor por meio das demais ferramentas. O mesmo ocorre com os elementos que esta pesquisa não conseguiu evidenciar ou operacionalizar;

- Analogamente, as dificuldades identificadas na verificação da questão Q4, também podem, de uma forma geral, ser estendidas ao desafio de mapear a participação do consumidor em processos de serviço por meio das demais ferramentas.

\subsection{LIMITAÇÕES DO TRABALHO}

Examinando os dados e evidências produzidos por esta pesquisa e as análises e discussões elaboradas com base nos mesmos, pode-se concluir que as questõeschave que nortearam este trabalho foram adequadamente elucidadas. No entanto, é preciso ressalvar que o estudo desenvolvido não é exaustivo, na medida em que se limita ao contexto de um tipo específico de serviço: os serviços "faça você mesmo". Além disso, aborda somente o caso de um serviço específico no estudo de cada uma das duas formas de participação do consumidor no processo que foram consideradas, quais sejam, com interação remota e com interação presencial.

A limitação de escopo assumida nesta pesquisa não enfraquece as conclusões acerca do processo de mapeamento e medição das tarefas executadas pelos consumidores, uma vez que existe uma grande quantidade de serviços cujos processos de atendimento baseiam-se num padrão de interação com o consumidor muito semelhante ao observado nos casos focados.

A aplicação de ferramentas de mapeamento para construção de mapas que permitam a visualização da participação do consumidor em processos de serviço mostra-se de extrema importância para a busca de uma ampla compreensão da forma como isso ocorre e para a proposição de melhorias no processo que proporcionem maior valor ao cliente. Urge, portanto, buscar avanços no campo da 
gestão de operações de serviço a fim de compreender e analisar de forma mais criteriosa a participação do consumidor como coprodutor do serviço.

Conforme se verificou no desenvolvimento deste estudo, foram enfrentadas dificuldades na coleta e análise de dados apesar dos processos de serviço tomados como objetos de estudo serem constituídos de um fluxo único e padronizado de tarefas do tipo "faça você mesmo", o que reduz as oportunidades de interferência na interação entre empresa e consumidor.

Isso indica que embora desejável o processo de mapeamento e avaliação de participação do consumidor em processos de serviço não é trivial e impõe grandes desafios metodológicos. Entende-se, por outro lado, que existe a necessidade de se expandir a análise realizada para serviços mais complexos nos quais ocorra interação entre consumidor e funcionários da empresa provedora do serviço e para casos de serviços em que o processo apresente possibilidades de ramificações ao longo do fluxo de tarefas do consumidor.

Adicionalmente, é preciso considerar a necessidade de desenvolver pesquisas que avaliem a participação do consumidor nos processos de serviço de forma a entender como se pode reduzir o esforço do consumidor e aumentar sua satisfação com a execução do processo.

\subsection{SUGESTÕES DE NOVOS TRABALHOS}

O presente trabalho tratou especificamente da aplicação da ferramenta Mapa de Consumo para os processos de serviço do tipo "faça você mesmo" com interação remota e com interação presencial. Novos trabalhos acerca da aplicabilidade de ferramentas de mapeamento das tarefas desempenhadas pelos consumidores podem ser desenvolvidos, conforme proposto a seguir:

- Verificar a aplicabilidade da ferramenta Mapa de Consumo para outros tipos de serviço; 
- Verificar a aplicabilidade das ferramentas de mapeamento SIPOC, Blueprint, Carta de Atividades e SERVPRO em processos reais de consumo do serviço nos quais o consumidor tenha participação ativa na execução do processo;

- Testar a aplicação de outros métodos de coleta de dados para captura do fluxo de tarefas realizadas pelos consumidores e para coleta de dados do tempo gasto e do grau de satisfação dos consumidores em relação a cada tarefa;

- Verificar outros aspectos presentes nos processos de serviço que poderiam ser examinados pelo pesquisador e representados por meio de ferramentas de mapeamento para melhor compreensão da participação do consumidor nos processo de serviço;

- Explorar a questão das empresas provedoras de serviço não darem importância ao mapeamento das tarefas executadas pelos consumidores a fim de compreender as razões desta postura;

Um possível método de coleta de dados para o desenvolvimento de novos estudos sobre mapeamento e medição das atividades executadas remotamente pelos consumidores é a aplicação do rastreamento das telas do computador do consumidor. $\mathrm{O}$ rastreamento das telas do computador significaria realizar um acesso remoto ao computador do consumidor enquanto o mesmo executa algum processo, desta forma seria possível observar o fluxo de tarefas seguido e medir o tempo gasto com as mesmas.

Outro método para mapear a participação do consumidor em processos de serviço realizados remotamente pelos consumidores é o mecanismo de rastreamento de olhos no qual uma câmera capta a direção do olhar das pessoas. Através deste método de coleta de dados seria possível identificar, para os serviços executados remotamente, a sequência de movimentos seguida pelo consumidor na execução das tarefas sob sua responsabilidade.

Propõe-se que os estudos acerca de processos de serviços mais complexos (em que ocorram interações entre funcionários da empresa provedora do serviço e consumidor) e a análise da participação do consumidor com o propósito de buscar melhorias no processo sob a perspectiva não somente da empresa provedora, mas também do consumidor, sejam suportados pelo Modelo da Lógica do Serviço 
(Service Logic Model) proposto por Kingman-Brundage, George e Bowen (1995), que possibilita compreender de forma mais estruturada a interação entre a lógica do consumidor, a lógica do funcionário e a lógica técnica.

Por fim, verifica-se a necessidade de desenvolver estudos que complementem as ferramentas de mapeamento existentes na literatura de forma a considerar outros aspectos relevantes associados ao processo de consumo de serviço e assim contribuam para retratar o serviço na sua completude.

Diante do exposto, espera-se que esta dissertação tenha contribuído para ampliar os conhecimentos na área investigada e que possa incentivar o desenvolvimento de novas pesquisas que contemplem a participação do consumidor em processos de serviço sob a perspectiva do consumidor. 


\section{REFERÊNCIAS 9}

ALBRECHT, KARL. Revolução nos serviços: como as empresas podem revolucionar a maneira de tratar os seus clientes. Estados Unidos: Pioneira, 1992.

ANDERSON, J.C.; JAINB, D.C.; CHINTAGUNTAC, P.K. Customer value Assessment in Business Markets: A State-of-Practice Study. Journal of Businessto-Business Marketing, v. 1, n. 1, p. 3-29, 1992.

ARAUJO, M. Compra coletiva oferece descontos e gera visibilidade para o vendedor. Jornal da Globo, edição do dia 21 out. 2010. Disponível em: <http://g1.globo.com/jornal-da-globo/noticia/2010/10/compra-coletiva-oferecedescontos-e-gera-visibilidade-para-o-vendedor.html> Acesso em: 22 set. 2011.

BARNES, R. M. Estudo de Movimentos e Tempos. São Paulo: Edgard Blücher, 1977.

BITNER, M. J.; OSTROM, A. L.; MORGAN, F.N. Service Blueprinting: A Practical Technique for Service Innovation. California Management Review, v. 50, n. 3, p. 66-95, 2008.

BOTEGA, N. J. Residência de Psiquiatria no hospital geral: uma enquete nacional. Jornal Brasileiro de Psiquiatria, v. 40, n. 8, p. 419-22, 1991.

BOWEN, J.; FORD, R. C. Managing Service Organizations: Does Having a "Thing" Make a Difference? Journal of Management, v. 28 (3), p. 447-469, 2002.

BRASIL, L. Depoimento dado em entrevista à pesquisadora. São Paulo, 2011.

BRITO, V. Estudo mostra 21 tendências do setor de Comércio e Serviços até 2015. Administradores, out. 2008. Disponível em: <http://www.administradores.com. br/informe-se/informativo/estudo-mostra-21-tendencias-do-setor-de-comercio-eservicos-ate-2015/18233/> Acesso em: 29 nov. 2011.

\footnotetext{
${ }^{9}$ De acordo com a Associação Brasileira de Normas Técnicas. NBR 6023. NBR 10520.
} 
CABRAL, D. O milagre por trás dos sites de compras coletivas. Administrador profissional. São Paulo, ano 34, n. 297, p. 28-31, mar. 2011.

CAIXETA, J.; FERNANDES, P. T.; BELL, G. S.; SANDER, J. W.; LI, M. L. Percepção de epilepsia em estudantes universitários: uma enquete. Arquivos de NeuroPsiquiatria, v. 65, suplemento 1, 2007.

CHANG, D.-S.; YANG, S.-L. Combining Kano model and service blueprint for adult day care service: A case study in Taiwan. 7th International Conference on Service Systems and Service Management, p. 1044-1048, 2010.

CHUANG, P.-T. Combining service blueprint and FMEA for service design. Service Industries Journal, v. 27, n. 2, p. 91-104, 2007.

COMPRA COLETIVA - nova estratégia de e-commerce. eCommerceOrg: Tudo sobre Comércio Eletrônico. Disponível em: <http://www.ecommerce.org.br/compra-coletiva.php> Acesso em: 22 set. 2011.

CORRÊA, H.L.; CORRÊA, C.A. Administração de produção e operações: manufatura e serviços: uma abordagem estratégica. São Paulo: Atlas, 2004.

DONALDSON, K. M.; ISHII, K.; SHEPPARD, S. D. Customer Value Chain Analysis. Research in Engineering Design, v. 16, p. 174-183, 2006.

EISENHARDT, K. M. Building Theories From Case Study Research. The Academy of Management Review, v. 14, p. 532-550, 1989.

IBGE. Sala de Imprensa: Contas Nacionais Trimestrais-Indicadores de Volume. Rio de Janeiro: IBGE, 2011. Disponível em: <http://www.ibge.gov.br/home/ presidencia/noticias/noticia_visualiza.php?id_noticia=1830\&id_pagina $=1>$. Acesso em: 10 set. 2011.

FITZSIMMONS, J. A.; FITZSIMMONS, M. J. Administração de serviços: operações, estratégia e tecnologia de informação. 4. ed. São Paulo: Bookman, 2005. $537 \mathrm{p}$. 
FLIESS, S; BECKER, U. Supplier integration - Controlling of co-development processes. Industrial Marketing Management, v. 35, p. 28-44, 2006.

FLYNN, B. B.; SAKAKIBARA, S.; SCHROEDER, R. G.; BATES, K. A.; FLYNN, E. J. Empirical Research Methods in Operations Management. Journal of Operations Management, v. 9, n. 2, 1990.

FREITAS, H.; MOSCAROLA, J. Da observação à decisão: métodos de pesquisa e de análise quantitativa e qualitativa de dados. RAE - eletrônica, v. 1, n. 1, 2002.

GAVIOLI, G. Compra Coletiva. E-Commerce News: Absolutamente tudo sobre ecommerce. Disponível em: <http://ecommercenews.com.br/glossario/o-que-ecompra-coletiva> Acesso em: 22 set. 2011.

GIL, A.C. Métodos e técnicas de pesquisa social. 4 ed. São Paulo: Atlas, 1994.

Base de dados Google Analytics. 2011. Disponível em: $<$ https://www.google.com/analytics/web/\#report/visitors-overview/a21626524w42768 293p42732106/>. Acesso em: 29 set. 2011.

GUMMESSON, E. Quality, service-dominant logic and many-to-many marketing. The TQM Journal, v. 20, n. 2, p. 143-153, 2008a.

GUMMESSON, E. Extending the service-dominant logic: from customer centricity to balanced centricity. Journal of the Academy of Marketing Science, v. 36, p. 15-17, 2008b.

HESKETT, J. L.; SASSER, W. E.; SCHLESINGER, L. A. The Service Profit Chain. Nova York: Free Press, 1997, 301 p.

JOHNSTON, R.; CLARK, G. Administração de operações de serviço. São Paulo: Ed. Atlas, 2002, $562 \mathrm{p}$.

JOHNSTON, R.; JONES, P. Service productivity: Towards understanding the relationship between operational and customer productivity. International Journal of Productivity and Performance Management, v. 53, n. 3, p. 201-213, 2004. 
JIN, Y.; CURRAN, R.; BUTTERFIELD, J.; BURKE, R. A Quantitative Metric for Workstation Design for Aircraft Assembly. In: CURRAN, R.; CHOU, S.; TRAPPEY, A. Collaborative Product and Service Life Cycle Management for a Sustainable World. London: Springer-Verlag London Limited, 2008, p. 523-530.

KEEGAN, W. J.; GREEN, M. Princípios de marketing global. São Paulo: Saraiva, 2000.

KINGMAN-BRUNDAGE, J.; GEORGE, W. R.; BOWEN, D. E. "Service logic": achieving service system integration. International Journal of Service Industry Management, v. 6, n. 4, p. 20-39, 1995.

KONING, H.; DOES, R.J.M.M., BISGAARD, S. Lean Six Sigma in financial services. International Journal of Six Sigma and Competitive Advantage, v.4, n.1, p. 1-17, 2008.

KUMAR, S.; HUDSON, B.; LOWRY, J. Consumer purchase process improvements in e-tailing operations: A case study. International Journal of Productivity and Performance Management, v. 59, n. 4, p. 388-403, 2010.

KUMAR, S.; STEINEBACH, M. Eliminating US hospital medical errors. International Journal of Health Care Quality Assurance, v. 21, n. 5, p. 444-471, 2008.

KUMAR, S.; STRANDLUND E.; THOMAS, D. Improved service system design using Six Sigma DMAIC for a major US consumer electronics and appliance retailer. International Journal of Retail \& Distribution Management, v. 36, n. 12, p. 970994, 2008.

LOCHER, D. Lean office and service simplified: the definitive how-to guide. New York: Taylor \& Francis Group, 2011, 173 p.

LOVELOCK, C. H.; GUMMESSON, E. Whither Services Marketing? In Search of a New Paradigm and Fresh Perspectives. Journal of Service Research, v. 7, n. 1, p. 20-41, 2004. 
MARCONI, M. A.; LAKATOS, E. M. Fundamentos de metodologia científica. $5^{\mathrm{a}}$ ed. São Paulo: Atlas, 2003.

MIGUEL, P. A. C. Estudo de caso na engenharia de produção: estruturação e recomendações para sua condução. Produção, v. 17, n. 1, p. 216-229, 2007.

MIGUEL, P. A. C. (Coord.). Metodologia de Pesquisa em Engenharia de Produção e Gestão de Operações. Rio de Janeiro: Elsevier, 2010, 225 p.

MONROE, K. B. Pricing - Making Profitable Decisions. New York: McGraw-Hill, 1991.

MONTAGNER, P.; BERNARDES, R. C.; MATTEO, M. A Demanda por Serviços: o que há de novo na economia paulista. São Paulo em Perspectiva, v. 13 (1-2), 1999.

RAVALD, A; GRÖNROOS, C. The value concept and relationship marketing. European Journal of Marketing, v. 30, n. 2, p. 19-30, 1996.

RASMUSSON, D. The SIPOC Picture Book: A Visual Guide to the SIPOC/DMAIC Relationship. Madison: Oriel Incorporated, 2006, 19 p.

RODRIGUES, D. M. Tecnologia da informação na micro e pequena empresa: um levantamento sobre sua utilização no pólo moveleiro de Votuporanga - SP. Dissertação de Mestrado apresentada à Escola de Engenharia de São Carlos da Universidade de São Paulo, 2002, 139 p.

ROTHER, M.; SHOOK, J. Learning to See: Value Stream Mapping to Add Value and Eliminate MUDA. Cambridge: The Lean Enterprise Institute, 2008, 102 p.

SANTOS, L. C.; FACHIN, G. R. B.; VARVAKIS, G. Gerenciando processos de serviços em bibliotecas. Ciência da Informação. V. 32, n. 2, p. 85-94, 2003.

SANTOS, L. C.; VARVAKIS, G. SERVPRO: uma técnica para a gestão de operações de serviços. Revista Produção, v. 12, n. 1, 2002. 
SHOSTACK, G. L. Service Positioning through Structural Change. The Journal of Marketing, v. 51, n. 1, p. 34-43, 1987.

SILVA, M. T.; LANCMAN, S.; ALONSO, C. M. C. Consequências da intangibilidade na gestão dos novos serviços de saúde mental. Revista de Saúde Pública, v. 43, p. 36-42, 2009. Suplemento 1.

SILVA, M. T. A Organização do trabalho para a produção de acordo com a lógica de serviço: os mecanismos de coordenação em atividades de atendimento ao cliente. Tese de livre docência apresentada ao Departamento de Engenharia de Produção da Escola Politécnica da Universidade de São Paulo, 2010.

SILVESTRO, R.; FITZGERALD, L.; JOHNSTON, R.; VOSS, C. Towards a Classification of Service Processes. International Journal of Service Industry Management, v. 3, n. 3, p. 62-75, 1992.

TORRES JUNIOR, N. Operações em serviços de resultados ulteriores: diretrizes gerenciais para um melhor desempenho. Tese de doutorado apresentada ao Departamento de Engenharia de Produção da Escola Politécnica da Universidade de São Paulo, 2007.

VANDERMERWE, S.; RADA, J. Servitization of business: adding value by adding services. European Management Journal, v. 6, n. 4, p. 314-324, 1988.

VOSS, C. Trusting the Internet: developing an e-service strategy. Colchester: Institute of Customer Service, 2000.

VOSS, C.; TSIKRIKTSIS, N.; FROHLICH, M. Case research in operations management. International Journal of Operations \& Production Management, v. 22, n. 2, p. 195-219, 2002.

VOSS, C.; ZOMERDIJK, L. Innovation in Experiential Services - An Empirical View. London: London Business School, 2007, 40 p.

THIOLLENT. Crítica metodológica, investigação social e enquete operária. São Paulo: Polis, 1982. 
WOMACK, J. P.; JONES, D. T. Lean Thinking: Banish Waste and Create Wealth in Your Corporation, Simon \& Schuster, Nova York, 1996.

Review, março, 2005.

. Lean Consumption. Harvard Business

Soluções Enxutas Lean Solutions: Como Empresas e Clientes Conseguem Juntos Criar Valor e Riqueza. Rio de Janeiro: Campus, 2006, 298 p.

ZEITHAML, V. A.; BITNER, M. J. Marketing de Serviços: A Empresa com Foco no Cliente. $2^{2}$ Edição. Porto Alegre: Bookman, 2003. 


\section{APÊNDICE A - Questionário utilizado como guia para realização das entrevistas com as empresas de compra coletiva.}

1) História resumida da empresa, mês e ano de estabelecimento e foco de atuação (se tiver algum específico).

2) A empresa controla o tempo médio gasto pelos clientes no site?

3) A empresa controla o tempo gasto pelo cliente:

a. Do instante em que clica "Efetuar cadastramento" até finalizar o preenchimento do cadastro no site

b. Do instante em que acessa o site até clicar "Compre"

c. Do instante em que clica "Compre" até finalizar o pagamento

d. Do instante em que finaliza o pagamento até o site enviar o cupom para a conta de e-mail do cliente

4) Como o site foi desenvolvido? Com tecnologia comprada ou tecnologia de desenvolvimento próprio?

5) $O$ site foi pensado para se tornar de fácil usabilidade (intuitivo) para o consumidor?

6) A empresa acompanha de alguma forma o tempo gasto pelo consumidor no site e as possíveis dificuldades/erros enfrentados durante a compra? 


\section{APÊNDICE B - Entrevista realizada para prospectar empresa para o estudo de caso da categoria de serviço "faça você mesmo" com interação remota.}

A pesquisadora entrevistou a empresa A para explorar a viabilidade de desenvolver o estudo de caso junto a mesma, porém, ela não revelou condições de fornecer os dados necessários a construção de uma Mapa de Consumo.

A empresa A foi criada em outubro de 2010, e ainda apresenta uma estrutura familiar tendo o mercado da cidade de São Paulo como seu foco de atuação. Seus fundadores perceberam a receptividade do mercado consumidor aos sites de compra coletiva e optaram por apostar neste mercado em ascensão. Buscando consolidar-se neste mercado a empresa está expandindo suas operações para outras cidades e construindo sites específicos direcionados para bairros da cidade de São Paulo.

A empresa A serve de intermediadora entre clientes e empresas prestadoras de serviço ofertando em seu site serviços com descontos que variam de $50 \%$ a $90 \%$. A empresa trabalha ofertando até seis promoções por dia, desde que as ofertas não sejam de serviços concorrentes, ou seja, empresas com o mesmo tipo de serviço não têm ofertas com descontos anunciados pelo site no mesmo dia. A promoção somente torna-se válida quando um número mínimo de consumidores adere à promoção realizando a compra no site para concretizar uma compra coletiva. Após a realização da compra a empresa repassa o valor arrecadado à empresa que prestará o serviço final ao consumidor retendo uma parte do pagamento (pela intermediação da venda) e envia por e-mail aos clientes o cupom referente à oferta adquirida em até 24 horas.

Em relação à usabilidade do site a empresa $A$ optou por seguir o padrão básico adotado pelos demais sites que já estavam atuando no mercado de compras coletivas, inclusive utilizando no início da sua operação um site semi-pronto (comprado) enquanto sua estrutura própria estava em construção. A empresa A acredita que o processo do consumidor é bastante simples e relatou que poucas dúvidas foram enviadas pelos clientes em relação ao manuseio das funções do site e execução da compra. No entanto, por meio de registros mantidos em seus sistemas computadorizados a empresa verificou que alguns clientes acessam mais 
de uma vez a mesma promoção até conseguir finalizar a compra. Um dos sócios da empresa relatou que, aproximadamente, $8 \mathrm{em}$ cada 10 clientes consegue finalizar a compra no primeiro acesso. Os que não finalizam a compra na primeira tentativa, geralmente, conseguem finalizar o processo no segundo acesso, porém a empresa já observou casos de clientes que chegaram ao máximo de 10 acessos antes de finalmente finalizar a compra.

Apesar dos dados acima indicarem um possível retrabalho das tarefas executadas pelo consumidor, a empresa considera muito difícil entender os motivos que levam o cliente a executar várias tentativas de compra ou o que levaria um consumidor a ter mais dificuldades do que outro ou, ainda, o que levaria alguém a demorar mais tempo para finalizar a compra.

A empresa A não registra em seus sistemas o tempo dedicado pelo consumidor no site para execução da compra e considera que esta informação não seria de extrema relevância para o bom desempenho e aceitação do site, uma vez que existe uma grande semelhança entre os sites de compra coletiva e que uma pequena variação do tempo e esforço do consumidor para executar a compra não influenciaria a desistência da compra.

Por outro lado, o site se preocupa em controlar indicadores como: perfil dos clientes que mais compram, promoções mais acessadas e mais vendidas, tipo de serviço mais vendido, retorno financeiro das ofertas realizadas pelo site. 
APÊNDICE C - Planilha eletrônica de medição e instruções enviadas para potenciais consumidores para realização do experimento 
Instruções

Para salvar a planilha: Salvar como $\rightarrow$ Selecione a opção "Tipo: Pasta de Trabalho Habilitada para Macro do Excel".

Insira seu nome no campo: "Nome Comprador" e no "Número da Compra" insira um número sequencial $(1,2,3,4 \ldots)$ a cada nova compra mude este número.

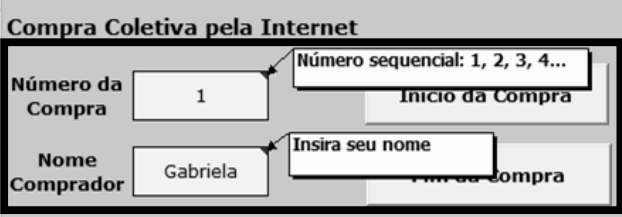

Atividade:

- Efetua compra no site

(Desde clicar em "Comprar" até

finalização e confirmação do pagamento)

Quando decidir efetuar a compra em um dos sites de compra coletiva clicar no botão "Iniciar Compra" (logo antes de clicar no botão "comprar" do site).

Será registrado o horário de início da sua compra na planilha!

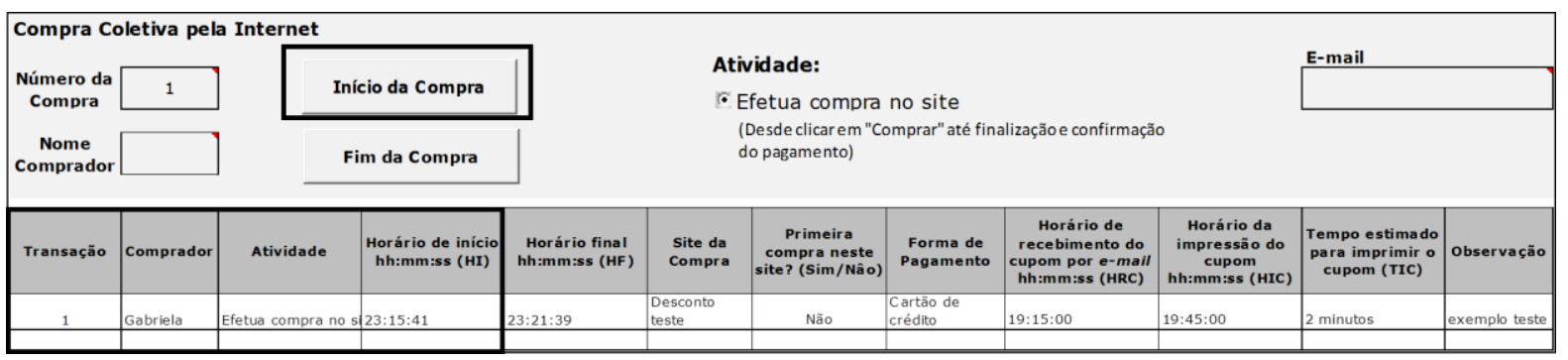

Ao finalizar o pagamento da oferta no site de compra coletiva clicar no botão "Fim da Compra" (logo após finalizar o pagamento).

Será registrado o horário final da sua compra na planilha!

Preencha os demais dados da planilha: "Site da compra" e "Forma de pagamento".

Salve a planilha e guarde para utilizar posteriormente.

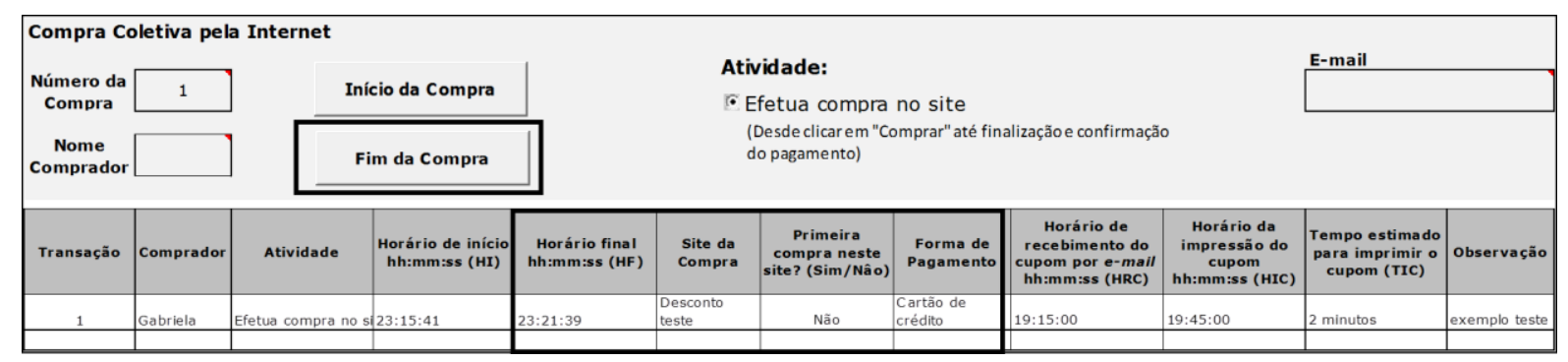


Quando for imprimir o cupom do desconto preencha os demais campos da planilha: "Horário de recebimento do cupom (e-mail)", "Horário da impressão do cupom", "Tempo estimado para imprimir o cupom".

\begin{tabular}{|c|c|c|c|c|c|c|c|c|c|c|c|}
\hline \multicolumn{12}{|c|}{ Compra Coletiva pela Internet } \\
\hline \multirow{3}{*}{$\begin{array}{c}\text { Número da } \\
\text { Compra } \\
\text { Nome } \\
\text { Comprador }\end{array}$} & \multirow[b]{2}{*}{1} & \multirow{2}{*}{\multicolumn{2}{|c|}{ Início da Compra }} & \multirow{2}{*}{\multicolumn{4}{|c|}{ Atividade: }} & & & \multicolumn{2}{|l|}{ E-mail } \\
\hline & & & & \multirow{2}{*}{\multicolumn{6}{|c|}{$\begin{array}{l}\text { - Efetua compra no site } \\
\text { (Desde clicar em "Comprar" até finalizaçãoe confirmação } \\
\text { do pagamento) }\end{array}$}} & & \\
\hline & \multicolumn{3}{|r|}{ Fim da Compra } & & & & & & & & \\
\hline Transação & Comprador & Atividade & $\begin{array}{c}\text { Horário de início } \\
\text { hh:mm:ss (HI) }\end{array}$ & $\begin{array}{c}\text { Horário final } \\
\text { hh:mmm:ss (HF) }\end{array}$ & $\begin{array}{l}\text { Site da } \\
\text { Compra }\end{array}$ & $\begin{array}{c}\text { Primeira } \\
\text { compra neste } \\
\text { site? (Sim/Nâo) }\end{array}$ & $\begin{array}{c}\text { Forma de } \\
\text { Pagamento }\end{array}$ & \begin{tabular}{|c|} 
Horário de \\
recebimento do \\
cupom por e-mail \\
hh:mm:ss (HRC)
\end{tabular} & $\begin{array}{c}\text { Horário da } \\
\text { impressão do } \\
\text { cupom } \\
\text { hh:mm:ss (HIC) }\end{array}$ & $\begin{array}{c}\text { Tempo estimado } \\
\text { para imprimir o } \\
\text { cupom (TIC) }\end{array}$ & observação \\
\hline 1 & Gabriela & Efetua compra ne & s) $23: 15: 41$ & 23:21:39 & $\begin{array}{l}\begin{array}{l}\text { Desconto } \\
\text { teste }\end{array} \\
\end{array}$ & Não & $\begin{array}{l}\text { Cartão de } \\
\text { crédito }\end{array}$ & $19: 15: 00$ & $19: 45: 00$ & 2 minutos & exemplo teste \\
\hline & & & & & & & & & & & \\
\hline
\end{tabular}

Caso tenha qualquer observação sobre o processo, retrabalho, erro da planilha (linha deve ser desconsiderada/ deletada), sugestão para o processo, erro no site, etc. insira no campo de OBSERVAÇÃO!

Caso você tenha interesse em receber os resultados desta pesquisa adicione seu $e$ mail no campo indicado na planilha!

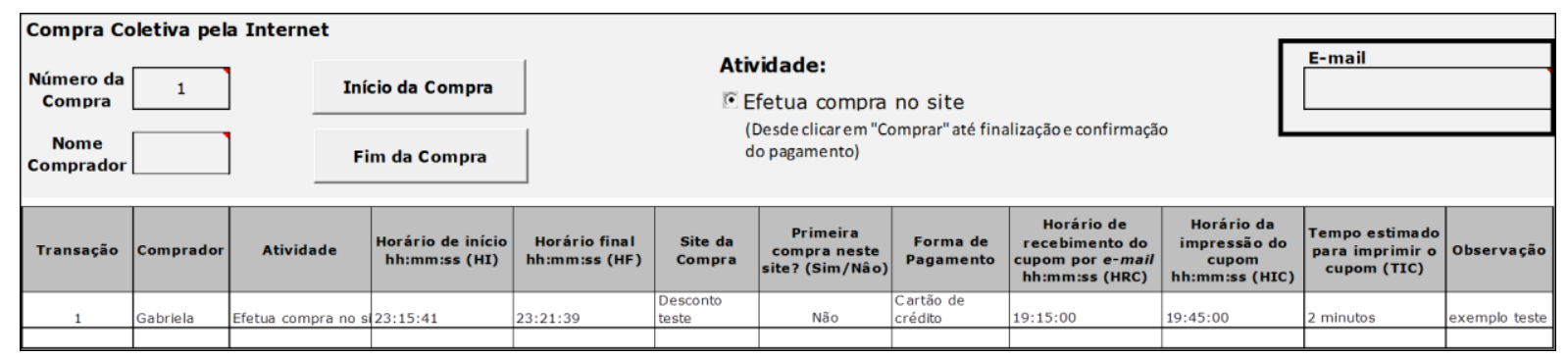




\section{APÊNDICE D - Versão inicial da planilha eletrônica de medição utilizada na etapa piloto de planejamento do experimento}

Medição do Processo de Consumo: Compra via Internet

Amostra

Nome

1

Registrar Início Atividade

Registrar Fim Atividade

\section{Atividade:}

EVerifica opção de compra

CEfetua login/ cadastro no site

CSeleciona detalhes da compra

CInsere detalhes do paqamento

EConfere finalização da compra
Site:

\begin{tabular}{|l|l|l|l|l|l|l|}
\hline Amostra & Nome & Site & Atividade & Data/Hora Início & Data/Hora Fim & Observações \\
\hline & & & & & & \\
\hline & & & & & & \\
\hline \\
\hline
\end{tabular}


APÊNDICE E - Planilha de medição utilizada como base para realização da enquete visando a construção do Mapa de Consumo para um processo "faça você mesmo" com interação presencial

\begin{tabular}{|c|c|c|c|c|c|c|c|c|c|}
\hline Amostra & $\begin{array}{c}\text { Aceitou (S/N) } \\
\text { Participar }\end{array}$ & $\begin{array}{c}\text { Horário do } \\
\text { Ticket }\end{array}$ & $\begin{array}{l}\text { Horário da } \\
\text { Medição }\end{array}$ & $\begin{array}{c}\text { Tempo Gasto para } \\
\text { Estacionar }\end{array}$ & Satisfação & $\begin{array}{c}\text { Vaga } \\
\text { Especial }\end{array}$ & Observação & Comentário do consumidor & Data \\
\hline & & & & & & & & & \\
\hline & & & & & & & & & \\
\hline & & & & & & & & & \\
\hline & & & & & & & & & \\
\hline & & & & & & & & & \\
\hline & & & & & & & & & \\
\hline & & & & & & & & & \\
\hline & & & & & & & & & \\
\hline & & & & & & & & & \\
\hline & & & & & & & & & \\
\hline & & & & & & & & & \\
\hline & & & & & & & & & \\
\hline & & & & & & & & & \\
\hline & & & & & & & & & \\
\hline & & & & & & & & & \\
\hline & & & & & & & & & \\
\hline & & & & & & & & & \\
\hline & & & & & & & & & \\
\hline & & & & & & & & & \\
\hline
\end{tabular}


APÊNDICE F - Dados coletados na enquete visando a construção do Mapa de Consumo para um processo "faça você mesmo" com interação presencial

\begin{tabular}{|c|c|c|c|c|c|c|c|c|c|}
\hline Amostra & $\begin{array}{l}\text { Aceitou (S/N) } \\
\text { Participar }\end{array}$ & $\begin{array}{l}\text { Horário do } \\
\text { Ticket }\end{array}$ & $\begin{array}{l}\text { Horário da } \\
\text { Medição }\end{array}$ & $\begin{array}{l}\text { Tempo Gasto para } \\
\text { Estacionar }\end{array}$ & Satisfação & $\begin{array}{l}\text { Vaga } \\
\text { Especial }\end{array}$ & Observação & Comentário do consumidor & Data \\
\hline 1 & Sim & $17: 37$ & $17: 44$ & $0: 07$ & Indiferente & Não & & & $01 / 04 / 2012$ \\
\hline 2 & Sim & $17: 43$ & $17: 45$ & $0: 02$ & Satisfeito & Não & & & $01 / 04 / 2012$ \\
\hline 3 & Sim & $17: 38$ & $17: 46$ & $0: 08$ & Nervoso & Não & & $\begin{array}{l}\text { Sempre demoro muito para } \\
\text { encontrar uma vaga aqui }\end{array}$ & $01 / 04 / 2012$ \\
\hline 4 & Sim & $17: 40$ & $17: 49$ & 0:09 & Satisfeito & Não & & & 01/04/2012 \\
\hline 5 & Não & & & & & Não & & & 01/04/2012 \\
\hline 6 & Sim & $17: 17$ & $17: 52$ & $0: 35$ & Nervoso & Não & & $\begin{array}{c}\text { Neste shopping não existem } \\
\text { vagas suficientes }\end{array}$ & $01 / 04 / 2012$ \\
\hline 7 & Sim & $17: 47$ & $17: 54$ & 0:07 & Satisfeito & Sim & & & $01 / 04 / 2012$ \\
\hline 8 & Sim & - & $17: 55$ & $0: 05$ & Insatisfeito & Não & Sem parar & $\begin{array}{l}\text { Tenho dificuldade para estacionar, } \\
\text { pois tenho uma caminhonete }\end{array}$ & $01 / 04 / 2012$ \\
\hline 9 & Sim & - & $17: 57$ & 0:08 & Satisfeito & Não & Sem parar & & $01 / 04 / 2012$ \\
\hline 10 & Sim & - & $17: 57$ & $0: 05$ & Insatisfeito & Não & Sem parar & & $01 / 04 / 2012$ \\
\hline 11 & Sim & $17: 54$ & $17: 59$ & $0: 05$ & Indiferente & Não & & & $01 / 04 / 2012$ \\
\hline 12 & Sim & $17: 59$ & 18:05 & $0: 06$ & Insatisfeito & Não & & Exitem muitas vagas para idosos & $01 / 04 / 2012$ \\
\hline 13 & Sim & - & 18:07 & 0:05 & Satisfeito & Não & Sem parar & & 01/04/2012 \\
\hline 14 & Sim & - & 18:13 & $0: 05$ & Satisfeito & Não & Sem parar & & 01/04/2012 \\
\hline 15 & Sim & $18: 15$ & 18:22 & $0: 07$ & Indiferente & Não & & & $01 / 04 / 2012$ \\
\hline 16 & Não & & & & & & & & $01 / 04 / 2012$ \\
\hline 17 & Sim & $18: 17$ & $18: 22$ & 0:05 & Satisfeito & Não & & $\begin{array}{c}\text { Venho muito aqui e já sei onde } \\
\text { encontrar vaga }\end{array}$ & $01 / 04 / 2012$ \\
\hline 18 & Sim & - & $18: 23$ & 0:03 & Indiferente & Não & Sem parar & & $01 / 04 / 2012$ \\
\hline 19 & Sim & - & $18: 24$ & $0: 05$ & Indiferente & Não & Sem parar & As vagas são muito pequenas & $01 / 04 / 2012$ \\
\hline 20 & Sim & - & $18: 25$ & $0: 05$ & Satisfeito & Não & Sem parar & & $01 / 04 / 2012$ \\
\hline 21 & Não & & & & & & & & 01/04/2012 \\
\hline 22 & Não & & & & & & & & $01 / 04 / 2012$ \\
\hline 23 & Sim & $18: 24$ & $18: 30$ & 0:06 & Satisfeito & Não & & & $01 / 04 / 2012$ \\
\hline 24 & Não & & & & & & & & 01/04/2012 \\
\hline 25 & Não & & & & & & & & 01/04/2012 \\
\hline 26 & Sim & - & $18: 34$ & 0:01 & Insatisfeito & Não & Sem parar & & $01 / 04 / 2012$ \\
\hline 27 & Sim & $18: 30$ & $18: 35$ & $0: 05$ & Indiferente & Não & & & $01 / 04 / 2012$ \\
\hline 28 & Não & & & & & & & & 01/04/2012 \\
\hline 29 & Sim & - & $18: 43$ & $0: 03$ & Satisfeito & Não & Sem parar & $\begin{array}{c}\text { Normalmente é muito cheio aqui, } \\
\text { mas hoje foi tranquilo }\end{array}$ & $01 / 04 / 2012$ \\
\hline 30 & Sim & - & $18: 45$ & $0: 05$ & Insatisfeito & Não & Sem parar & & $01 / 04 / 2012$ \\
\hline 31 & Não & & & & & Não & & & 01/04/2012 \\
\hline 32 & Sim & $18: 42$ & $18: 54$ & $0: 12$ & Indiferente & Não & & & 01/04/2012 \\
\hline 33 & Não & & & & & & & & 01/04/2012 \\
\hline 34 & Não & & & & & & & & 01/04/2012 \\
\hline 35 & Sim & $18: 50$ & $18: 59$ & 0:09 & Satisfeito & Não & & & $01 / 04 / 2012$ \\
\hline 36 & Sim & - & 19:02 & $0: 10$ & Indiferente & Não & Sem parar & & $01 / 04 / 2012$ \\
\hline 37 & Sim & - & 19:04 & 0:01 & Insatisfeito & Não & Sem parar & A vaga é muito pequena & 01/04/2012 \\
\hline 38 & Sim & $5 \min$ & 19:05 & $0: 05$ & Indiferente & Não & & Desta vez foi fácil encontrar vaga & $01 / 04 / 2012$ \\
\hline 39 & Sim & - & 19:08 & 0:05 & Satisfeito & Não & Sem parar & & 01/04/2012 \\
\hline 40 & Sim & - & 19:10 & 0:06 & Satisfeito & Não & Sem parar & & $01 / 04 / 2012$ \\
\hline 41 & Sim & $18: 56$ & 19:12 & $0: 16$ & Satisfeito & Não & & & 01/04/2012 \\
\hline 42 & Sim & - & 19:14 & $0: 03$ & Indiferente & Não & Sem parar & As vagas são muito pequenas & 01/04/2012 \\
\hline 43 & Sim & - & $19: 10$ & $0: 05$ & Satisfeito & Não & Sem parar & & $01 / 04 / 2012$ \\
\hline 44 & Sim & 19:10 & $19: 16$ & 0:06 & Indiferente & Não & & & 01/04/2012 \\
\hline 45 & Sim & - & $19: 20$ & $0: 05$ & Satisfeito & Não & Sem parar & & $01 / 04 / 2012$ \\
\hline 46 & Sim & $19: 17$ & $19: 23$ & $0: 06$ & Satisfeito & Não & & $\begin{array}{c}\text { Tem gente que para em duas } \\
\text { vagas }\end{array}$ & $01 / 04 / 2012$ \\
\hline 47 & Sim & - & 19:37 & $0: 15$ & Satisfeito & Não & Sem parar & & $01 / 04 / 2012$ \\
\hline 48 & Sim & - & $19: 40$ & 0:05 & Satisfeito & Não & Sem parar & & $01 / 04 / 2012$ \\
\hline
\end{tabular}




\begin{tabular}{|c|c|c|c|c|c|c|c|c|c|}
\hline Amostra & $\begin{array}{l}\text { Aceitou (S/N) } \\
\text { Participar }\end{array}$ & $\begin{array}{c}\text { Horário do } \\
\text { Ticket }\end{array}$ & $\begin{array}{l}\text { Horário da } \\
\text { Medição }\end{array}$ & $\begin{array}{c}\text { Tempo Gasto para } \\
\text { Estacionar }\end{array}$ & Satisfação & $\begin{array}{c}\text { Vaga } \\
\text { Especial }\end{array}$ & Observação & Comentário do consumidor & Data \\
\hline 49 & Sim & - & $19: 00$ & 0:05 & Satisfeito & Não & Sem parar & & 05/04/2012 \\
\hline 50 & Sim & $18: 56$ & 19:00 & $0: 04$ & Satisfeito & Não & & & 05/04/2012 \\
\hline 51 & Não & & & & & & & & 05/04/2012 \\
\hline 52 & Não & & & & & & & & 05/04/2012 \\
\hline 53 & Sim & 19:01 & 19:06 & $0: 05$ & Satisfeito & Não & & & 05/04/2012 \\
\hline 54 & Sim & - & 19:09 & 0:02 & Satisfeito & Não & Sem parar & & 05/04/2012 \\
\hline 55 & Sim & - & 19:11 & 0:02 & Satisfeito & Não & Sem parar & As vagas são muito pequenas & 05/04/2012 \\
\hline 56 & Não & & & & & & & & 05/04/2012 \\
\hline 57 & Não & & & & & & & & 05/04/2012 \\
\hline 58 & Sim & - & 19:16 & 0:01 & Satisfeito & Não & Sem parar & & 05/04/2012 \\
\hline 59 & Não & & & & & & & & 05/04/2012 \\
\hline 60 & Não & & & & & & & & 05/04/2012 \\
\hline 61 & Sim & $19: 17$ & 19:22 & $0: 05$ & Satisfeito & Não & & & 05/04/2012 \\
\hline 62 & Sim & $19: 16$ & 19:23 & $0: 07$ & Satisfeito & Não & & & 05/04/2012 \\
\hline 63 & Não & & & & & & & & 05/04/2012 \\
\hline 64 & Sim & $19: 24$ & $19: 29$ & 0:05 & Satisfeito & Não & & & 05/04/2012 \\
\hline 65 & Sim & - & 19:31 & $0: 02$ & Satisfeito & Não & Sem parar & & 05/04/2012 \\
\hline 66 & Sim & 19:32 & 19:35 & $0: 03$ & Satisfeito & Não & & & 05/04/2012 \\
\hline 67 & Sim & - & $19: 36$ & $0: 02$ & Satisfeito & Não & Sem parar & Aqui é muito quente & 05/04/2012 \\
\hline 68 & Não & & & & & & & & 05/04/2012 \\
\hline 69 & Sim & $19: 32$ & $19: 38$ & $0: 06$ & Satisfeito & Não & & & 05/04/2012 \\
\hline 70 & Sim & $19: 34$ & $19: 39$ & 0:05 & Satisfeito & Sim & & & 05/04/2012 \\
\hline 71 & Não & & & & & & & & $05 / 04 / 2012$ \\
\hline 72 & Sim & $19: 34$ & $19: 41$ & $0: 07$ & Satisfeito & Não & & As vagas são pequenas & 05/04/2012 \\
\hline 73 & Não & & & & & & & & 05/04/2012 \\
\hline 74 & Sim & - & $19: 44$ & 0:01 & Satisfeito & Não & Sem parar & & $05 / 04 / 2012$ \\
\hline 75 & Não & & & & & & & & $05 / 04 / 2012$ \\
\hline 76 & Não & & & & & & & & 05/04/2012 \\
\hline 77 & Sim & - & $20: 06$ & $0: 05$ & Satisfeito & Não & Sem parar & & 05/04/2012 \\
\hline 78 & Sim & $20: 23$ & $20: 28$ & 0:05 & Satisfeito & Não & & & 05/04/2012 \\
\hline 79 & Sim & - & $20: 37$ & $0: 10$ & Satisfeito & Não & Sem parar & & 05/04/2012 \\
\hline 80 & Não & & & & & & & & $05 / 04 / 2012$ \\
\hline 81 & Sim & - & $20: 43$ & $0: 01$ & Satisfeito & Não & Sem parar & & 05/04/2012 \\
\hline 82 & Não & & & & & & & & 05/04/2012 \\
\hline 83 & Não & & & & & & & & 05/04/2012 \\
\hline 84 & Não & & & & & & & & 05/04/2012 \\
\hline 85 & Não & & & & & & & & 05/04/2012 \\
\hline
\end{tabular}

